\title{
Does TENS Reduce the Intensity of Acute and Chronic Pain? A Comprehensive Appraisal of the Characteristics and Outcomes of 169 Reviews and 49 Meta-Analyses
}

\author{
Carole A. Paley ${ }^{1,2}\left(\mathbb{D}\right.$, Priscilla G. Wittkopf ${ }^{1}$, Gareth Jones ${ }^{1}$ and Mark I. Johnson ${ }^{1, *(\mathbb{D})}$ \\ 1 Centre for Pain Research, Leeds Beckett University, Leeds LS1 3HE, UK; carole.paley@nhs.net (C.A.P.); \\ p.wittkopf@leedsbeckett.ac.uk (P.G.W.); g.j.Jones@leedsbeckett.ac.uk (G.J.) \\ 2 Research and Development Department, Airedale National Health Service (NHS) Foundation Trust, Skipton \\ Road, Steeton, Keighley BD20 6TD, UK \\ * Correspondence: m.johnson@leedsbeckett.ac.uk
}

check for

updates

Citation: Paley, C.A.; Wittkopf, P.G.; Jones, G.; Johnson, M.I. Does TENS Reduce the Intensity of Acute and Chronic Pain? A Comprehensive Appraisal of the Characteristics and Outcomes of 169 Reviews and 49 Meta-Analyses. Medicina 2021, 57, 1060. https://doi.org/10.3390/ medicina57101060

Academic Editor: Maxime Billot

Received: 3 August 2021

Accepted: 22 September 2021

Published: 4 October 2021

Publisher's Note: MDPI stays neutral with regard to jurisdictional claims in published maps and institutional affiliations.

Copyright: (c) 2021 by the authors. Licensee MDPI, Basel, Switzerland. This article is an open access article distributed under the terms and conditions of the Creative Commons Attribution (CC BY) license (https:// creativecommons.org/licenses/by/ $4.0 /)$.

\begin{abstract}
Background and Objectives: Uncertainty about the clinical efficacy of transcutaneous electric nerve stimulation (TENS) to alleviate pain spans half a century. There has been no attempt to synthesise the entire body of systematic review evidence. The aim of this comprehensive review was to critically appraise the characteristics and outcomes of systematic reviews evaluating the clinical efficacy of TENS for any type of acute and chronic pain in adults. Materials and Methods: We searched electronic databases for full reports of systematic reviews of studies, overviews of systematic reviews, and hybrid reviews that evaluated the efficacy of TENS for any type of clinical pain in adults. We screened reports against eligibility criteria and extracted data related to the characteristics and outcomes of the review, including effect size estimates. We conducted a descriptive analysis of extracted data. Results: We included 169 reviews consisting of eight overviews, seven hybrid reviews and 154 systematic reviews with 49 meta-analyses. A tally of authors' conclusions found a tendency toward benefits from TENS in 69/169 reviews, no benefits in 13/169 reviews, and inconclusive evidence in $87 / 169$ reviews. Only three meta-analyses pooled sufficient data to have confidence in the effect size estimate (i.e., pooled analysis of $>500$ events). Lower pain intensity was found during TENS compared with control for chronic musculoskeletal pain and labour pain, and lower analgesic consumption was found post-surgery during TENS. The appraisal revealed repeated shortcomings in RCTs that have hindered confident judgements about efficacy, resulting in stagnation of evidence. Conclusions: Our appraisal reveals examples of meta-analyses with 'sufficient data' demonstrating benefit. There were no examples of meta-analyses with 'sufficient data' demonstrating no benefit. Therefore, we recommend that TENS should be considered as a treatment option. The considerable quantity of reviews with 'insufficient data' and meaningless findings have clouded the issue of efficacy. We offer solutions to these issues going forward.
\end{abstract}

Keywords: transcutaneous electric nerve stimulation (TENS); pain; pain management; analgesia; efficacy; neuromodulation; systematic review; meta-analysis

\section{Introduction}

Transcutaneous electrical nerve stimulation (TENS) is a non-pharmacological technique used across the world for the management of acute and chronic pain irrespective of cause, including pain related to cancer and its treatment [1]. There has been a longstanding debate about the clinical efficacy of TENS since its introduction into mainstream healthcare in the early 1970s [2]. The first systematic reviews on TENS were published in mid 1990s and raised uncertainty about the clinical efficacy of TENS for acute and for chronic pain [3-5]. This uncertainty remains unresolved to this day.

In 2020, an overview of Cochrane reviews on TENS for chronic pain included a descriptive analysis of 51 RCTs (2895 participants) from eight reviews and was unable to 
conclude with confidence whether TENS was beneficial or harmful when used to manage pain [6]. It was observed that the quality of the eight Cochrane reviews scored high on a checklist to assess multiple systematic reviews (A MeaSurement Tool to Assess systematic Reviews or AMSTAR), whereas the quality of individual RCTs was low due to inadequate sample sizes and risks of bias [7]. Generally, the authors of Cochrane reviews on TENS are reluctant to pool data for meta-analysis due to concern about heterogeneity undermining the precision of the estimates of effect.

Moore et al., suggested that meta-analyses with pooled pain intensity data fewer than 500 participants (or events) in each trial arm are at a high risk of bias and likely to produce effect estimates that are imprecise [8,9]. Authors of non-Cochrane systematic reviews have undertaken meta-analyses, although pooled data is often below 500 events per trial arm. We are aware of two meta-analyses that have come close to the threshold of acceptability suggested by Moore et al., and both found superiority for TENS over placebo; for alleviating chronic musculoskeletal pain [10], and for reducing acute post-operative analgesic consumption [11].

Recently, a review published in The Lancet, evaluated the benefits and harms of neuromodulation for chronic pain and reported low-quality evidence of short-term benefit from TENS for neuropathic pain and conflicting evidence for non-neuropathic conditions [12]. The reviewers claimed that they " ... searched MEDLINE, Embase, and Cochrane databases for a 16-year period beginning in December 2004, to December 2020, to identify randomised clinical trials, observational studies, systematic reviews, meta-analyses, and narrative reviews in English for inclusion in the text and tables" ([12], p. 2111). However, they based their conclusion on only three reviews; one Cochrane review on TENS pain in adults [13]; one overview of Cochrane Reviews on TENS for chronic pain [6]; and a literature review and meta-analysis of TENS for chronic back pain [14]. Despite being recent and conducted using rigorous methodologies, these reviews represent a small selection of available reviews. A free text search of PubMed (25 June 2021) reveals over 100 potential systematic reviews including 500 clinical trials. Evidence syntheses that do not fully or accurately evaluate and/or report all available literature can generate findings that are not reproducible and misrepresent the status of knowledge.

Aim

The aim of this comprehensive review is to critically appraise the characteristics and outcomes of systematic reviews evaluating the clinical efficacy of TENS for any type of acute and chronic pain in adults.

\section{Methods}

We have published a protocol for a systematic review and meta-analysis of RCTs to evaluate TENS versus placebo TENS on pain intensity. The protocol included a literature search to identify systematic reviews and meta-analysis of TENS in order to conduct a descriptive analysis of the characteristics and outcomes of previously published systematic reviews and meta-analyses as described herein (the Meta-TENS study, Prospero registration number CRD42019125054 [15]).

\subsection{Literature Search Methods}

The purpose of the search was to provide comprehensive coverage of a wide variety of pain conditions (broadly based on the World Health Organisation's (WHO) International Classification of Disease (ICD-11) categories for pain), at various stages (e.g., acute, chronic) and from various settings (e.g., palliative, community, primary, secondary, tertiary). We searched the following electronic databases using a combination of controlled vocabulary (i.e., medical subject headings (MeSH) and free-text terms) to identify published systematic reviews from inception to the date of the search: Cochrane Library (CENTRAL); MEDLINE (via PubMed); Embase (via OVID); CINAHL (via EBSCO); PsycINFO (via EBSCO); LILACS (via Birme); PEDRO; Web of Science; AMED (via OVID); SPORTDiscus (via EBSCO). 
We tailored searches to the individual databases by adapting the MEDLINE search strategy for the other databases listed. Search terms included combinations of the terms Transcutaneous Electric* Nerve Stimulation, Pain, Systematic review, and Meta-analysis (Supplementary Materials Section S1. Search Terms: Systematic Reviews). There were no language restrictions and we identified all relevant systematic reviews irrespective of language and translated articles where possible. The original search was conducted during July 2019 and updated on 8 June 2021.

\subsection{Eligibility Criteria}

We pre-specified TENS as non-invasive electrical stimulation of the skin using surface electrodes with the intention of stimulating peripheral nerves to alleviate pain using a standard TENS device. A standard TENS device “... generates pulsed electrical current delivered in a repetitive manner, with a maximum peak-to-peak amplitude of approximately 60 milliamperes (mA) into a 1 kilohm load" ([1], p. 12) and regardless of the device manufacturer. We considered an intervention TENS if pulsed electrical current was delivered in a repetitive manner using monophasic or biphasic waveforms and pulse frequencies no greater than 250 pulses per second (pps), pulse durations no greater than 1 millisecond (1000 microseconds) and any type of pulse pattern.

We included journal publications of full reports of reviews that included a systematic search for research and evaluation of efficacy using tallies of study outcome or pooling data for meta-analysis for any type of clinical pain in adults. We included systematic reviews of studies, overviews of systematic reviews of studies, and hybrid reviews that included studies and systematic reviews. We included reviews that evaluated TENS treatment on its own or as part of a broader review.

We defined TENS as treatments described by authors as 'TENS' and administered using a standard TENS device with the primary intention of stimulating peripheral nerves to alleviate pain; irrespective of technique (e.g., conventional TENS, acupuncture-Like TENS, high-frequency-low-intensity, low-frequency-high intensity, etc.), electrical characteristics of currents (pulsed current width, amplitude, frequency or pattern), dosage and regimen. We excluded reports:

- that did not undertake an evaluation of TENS using systematic methodology in the broadest sense (e.g., comprehensive reviews, opinion pieces, commentaries);

- That evaluated invasive nerve stimulation techniques (e.g., percutaneous electrical nerve stimulation and electro-acupuncture);

- $\quad$ where TENS was not a primary treatment (i.e., where TENS was a possible comparator);

- where the primary intention of TENS was not to stimulate peripheral nerves to alleviate pain (e.g., TENS for bladder dysfunction, constipation, dementia);

- focused on 'TENS-like' currents that considered output specifications of a standard TENS device (e.g., interferential current, microcurrent).

\subsection{Selection of Reviews}

Two review authors (PGW and MIJ) screened abstracts and titles against our eligibility criteria (Supplementary Materials Section S2; Operational Aide Memoires). Duplicates and records that clearly did not satisfy inclusion criteria were removed and full text reports obtained and screened for inclusion in our review. We did not anonymise records of systematic reviews during screening. Disagreements at any stage of the process were resolved by consensus using a third review author as arbiter (CAP or GJ). Violation of any of the following criteria resulted in exclusion from our review:

- $\quad$ report was not a review;

- $\quad$ report did not evaluate 'standard TENS';

- $\quad$ report did not evaluate TENS as a primary comparator i.e., TENS was a comparator rather than the primary treatment;

- $\quad$ report did not systematically search for RCTs;

- $\quad$ report did not evaluate pain intensity; 
- $\quad$ report did not evaluate clinical pain, i.e., evaluation of healthy human participants.

To overcome double counting of characteristics, we only included the most recent update of a review. We included the most recent Cochrane review unless there had been a subsequent journal publication of a Cochrane review that included additional RCTs. Generally, Cochrane reviews provided greater detail than journal reports. We only included the most recent update of non-Cochrane reviews conducted by the same review team.

\subsection{Extraction and Management of Information}

Two review authors (PGW and MIJ) extracted and tabulated information about:

- $\quad$ clinical condition;

- type and scope of review;

- number of TENS studies, and/or reviews used in the evaluation;

- whether a meta-analysis was undertaken;

- effect size estimates for pain intensity, if calculated;

- conclusion stated by authors as a direct quote from their manuscript.

\subsection{Data Analysis}

Analysis of Characteristics of Reviews

We extracted statements of conclusion from each review and categorised them as claiming evidence; tending to favour TENS (+), tending not to favour TENS (i.e., superior or inferior to control/placebo (-)), tending to be conflicting/inconclusive or insufficient to make a judgement (?).

In addition, we independently judged review outcome using criteria based on research by Dechartres et al. $[16,17]$ that suggests meta-analyses based on small to moderately sized trials produce stronger effect estimates than meta-analyses based on large trials. Moore et al. [9] have argued that in meta-analyses of pain outcomes credible estimates of effect need to be based on large trials or from pooling at least 500 events from many moderately sized trials. RCTs may be considered adequately powered with $\geq 200$ patients per treatment arm, moderately powered with 100-199 patients per treatment arm and underpowered with $<100$ patients per treatment arm $[18,19]$. Thus, we independently judged outcome according to the following criteria:

- $\quad$ sufficient evidence in favour of TENS (+) — pooled analysis of $\geq 500$ events or at least one RCT with $\geq 200$ participants in each arm of the trial;

- $\quad$ sufficient evidence in favour of control/placebo (-) - pooled analysis of $\geq 500$ events or at least one RCT with $\geq 200$ participants in each arm of the trial;

- $\quad$ sufficient evidence that is conflicting/inconclusive (=) - no analysis of pooled data and at least two RCTs with $\geq 200$ participants in each arm of the trial that are conflicting;

- insufficient evidence to make a judgement (?)—pooled analysis of $<500$ events or no RCTs with $\geq 200$ participants in each arm of the trial.

Finally, we extracted and compared effect size estimates of meta-analyses of data pooled from two or more RCTs for pain intensity for continuous data (i.e., mean difference or standardised mean difference).

\section{Results}

\subsection{Search Findings}

Our original search yielded 579 records of which, after removal of duplicates, we screened 527 records and reviewed 327 full text reports/Of these 158 were excluded and 169 were included in the review (Figure 1). 


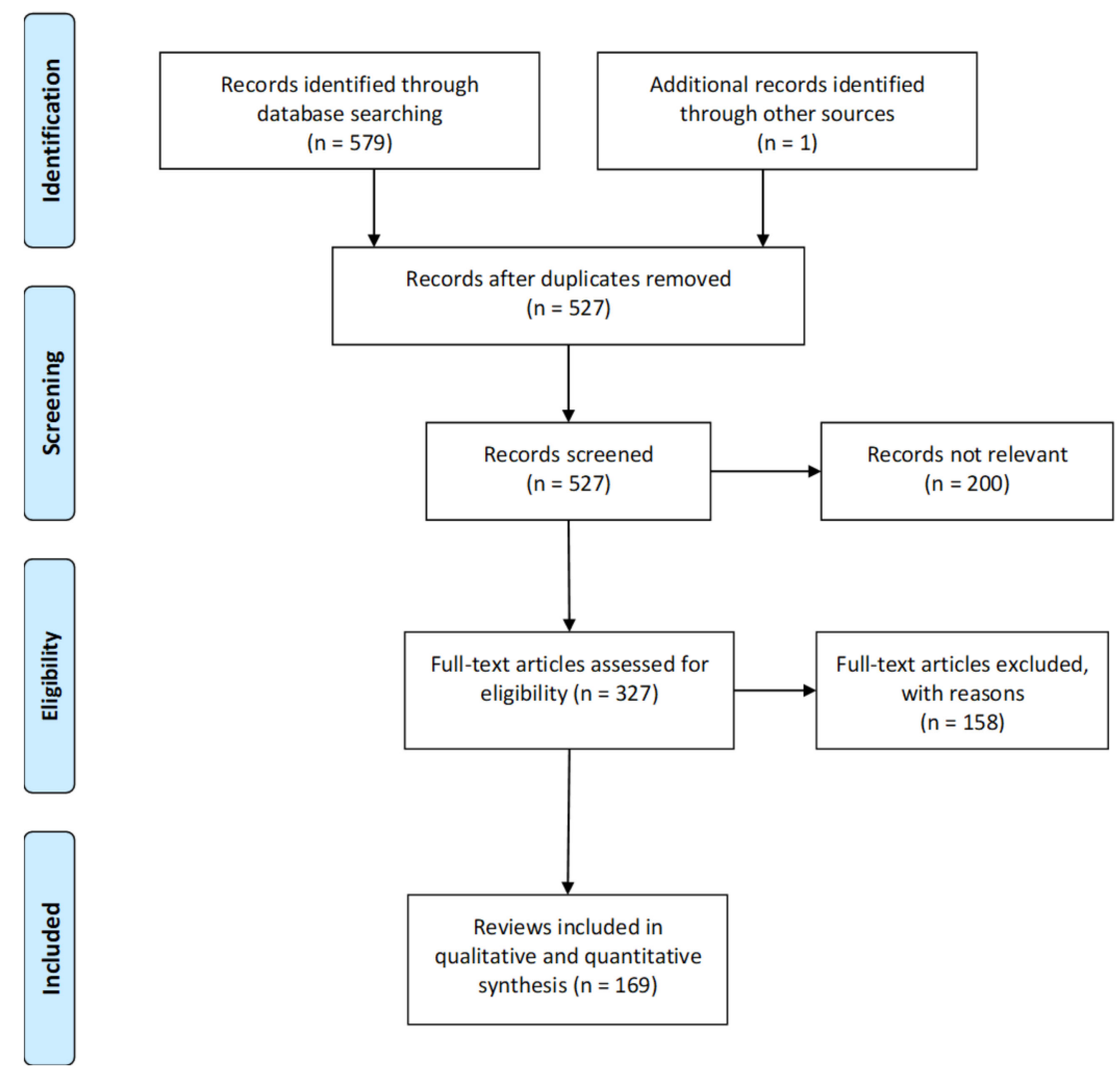

Figure 1. Flow chart of search and screening process.

\subsection{Description of Excluded Records}

The most common reason for excluding records was that they were narrative reviews on TENS that did not contain a systematic search of literature or that the systematic review had been updated (Supplementary Materials Table S1 Excluded Records with Reasons). Occasionally, we excluded more recent reports or updates of reviews because:

- TENS was in scope in the earlier review but out of scope in a later review. For example, TENS was in-scope in the 2007 report of the European Federation of Neurological Societies (EFNS) guidelines on neurostimulation therapy for neuropathic pain [20], but out of scope in the 2016 report [21].

- the earlier review was more comprehensive and included more studies that the later review. For example, we included a Cochrane review on TENS for labour pain published in 2009 by Dowswell et al. [22] rather than a later journal report of the Cochrane report published in 2011 by the same team (Bedwell et al. [23]).

\subsection{Characteristics of Included Reviews}

Figure 2 presents a flow chart summarising the sequence and outcomes of analyses of the characteristics of the reviews included in our appraisal. 


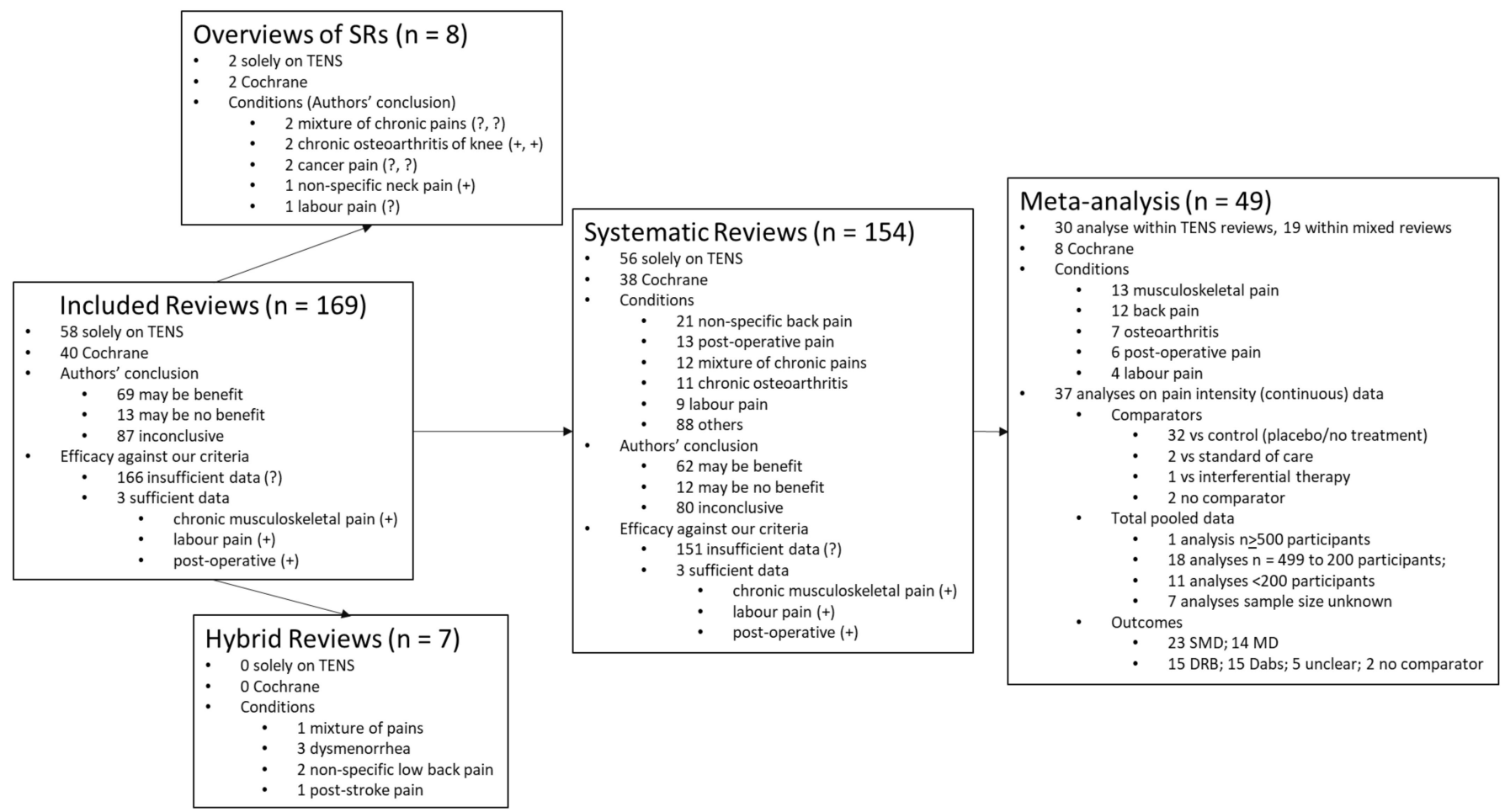

Figure 2. Flow chart summarising the sequence of analyses. Key: SMD, standardised mean difference; MD, mean difference; DRB, difference relative to baseline; Dabs, difference absolute (not relative to baseline); (+) authors' judgement—evidence tends toward benefit, (-) authors' judgement-evidence tends toward no benefit (?) authors' judgement-inconclusive.

We categorised 8/169 reports as overviews of systematic reviews that only evaluated previously published systematic reviews; $7 / 169$ reports as hybrid reviews that evaluated clinical studies and previously published systematic reviews; and 154/169 reports as systematic reviews of clinical studies (Figure 3a). There were 37/169 reports produced by Cochrane of which 35 were systematic reviews and two were overviews of Cochrane reviews. There were 84/169 reviews that evaluated TENS for chronic pain, 46/169 for acute pain, 25/169 for both acute and chronic and 14 reports were unclear (Figure 3b).

There were 40/169 reviews that evaluated TENS for 'non-specific' musculoskeletal pain excluding arthritic pain or pain associated with tendinopathy (tendinitis). Of the 'non-specific' musculoskeletal pain reviews 21 focused on chronic non-specific back pain and eight on chronic non-specific neck pain (Figure 3c). There were 13/169 reviews for osteoarthritis (10 of the knee only, three of knee and hip), 10/169 for labour pain, 13/169 for post-operative pain and 15/169 for a mixture of types of pain. The remainder of the reviews included evaluations of TENS for dysmenorrhea $(n=7)$, fibromyalgia $(n=6)$, cancer $(n=5)$, peripheral diabetic neuropathy $(n=5)$, pelvic pain $(n=4)$, post-stroke pain $(n=4)$, tendonitis $(n=4)$, spinal cord injury $(n=4)$, multiple sclerosis $(n=3)$, shoulder impingement $(n=3)$, post-amputation pain $(n=3)$, neuropathic pain $(n=3)$, procedural pain $(n=4)$, carpel tunnel syndrome $(n=2)$, bone fracture $(n=2)$, headache and/or migraine $(n=2)$ and rheumatoid arthritis $(n=2)$. There were a variety of other conditions with only one review. 


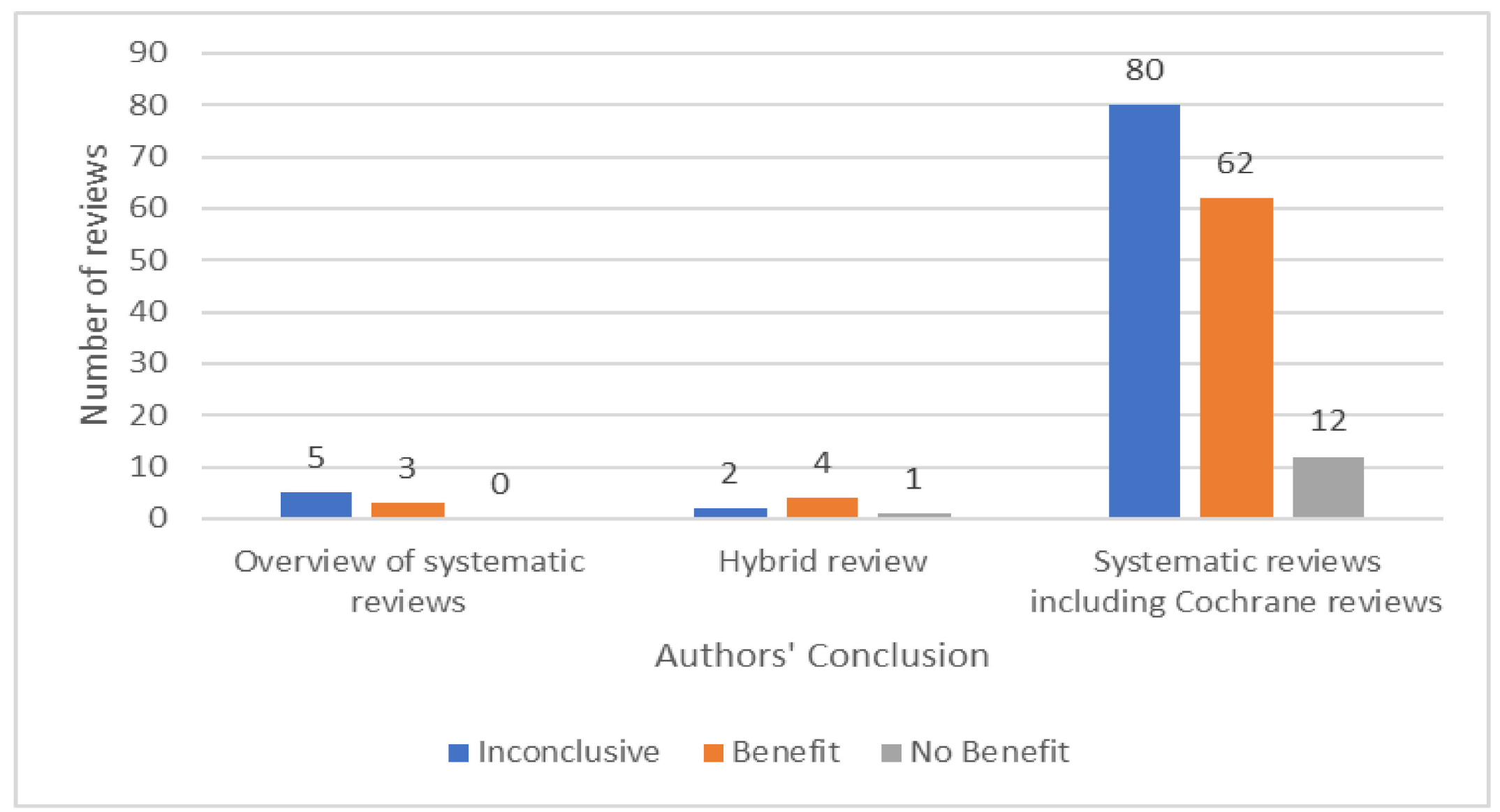

(a)

Figure 3. Cont. 


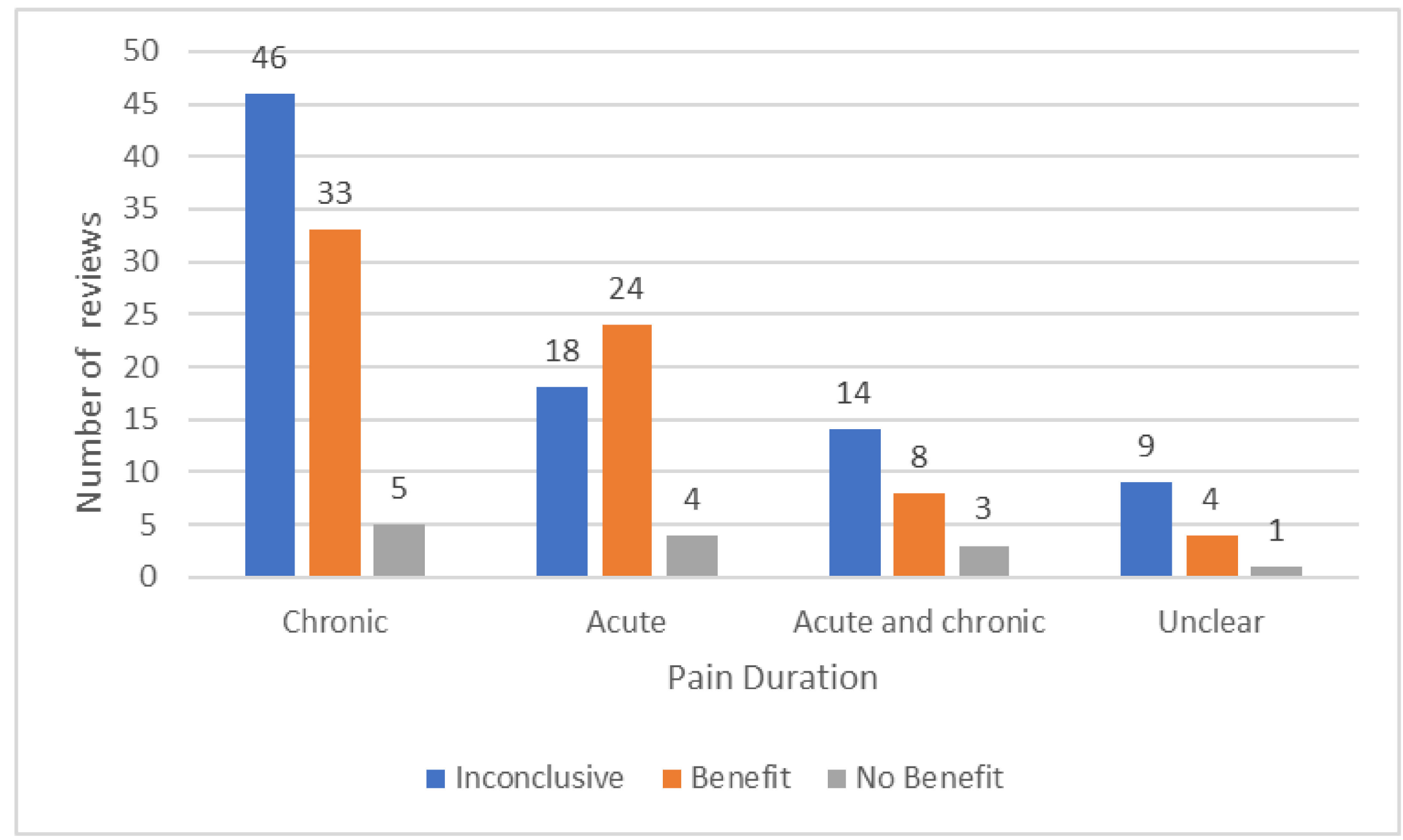

(b)

Figure 3. Cont. 


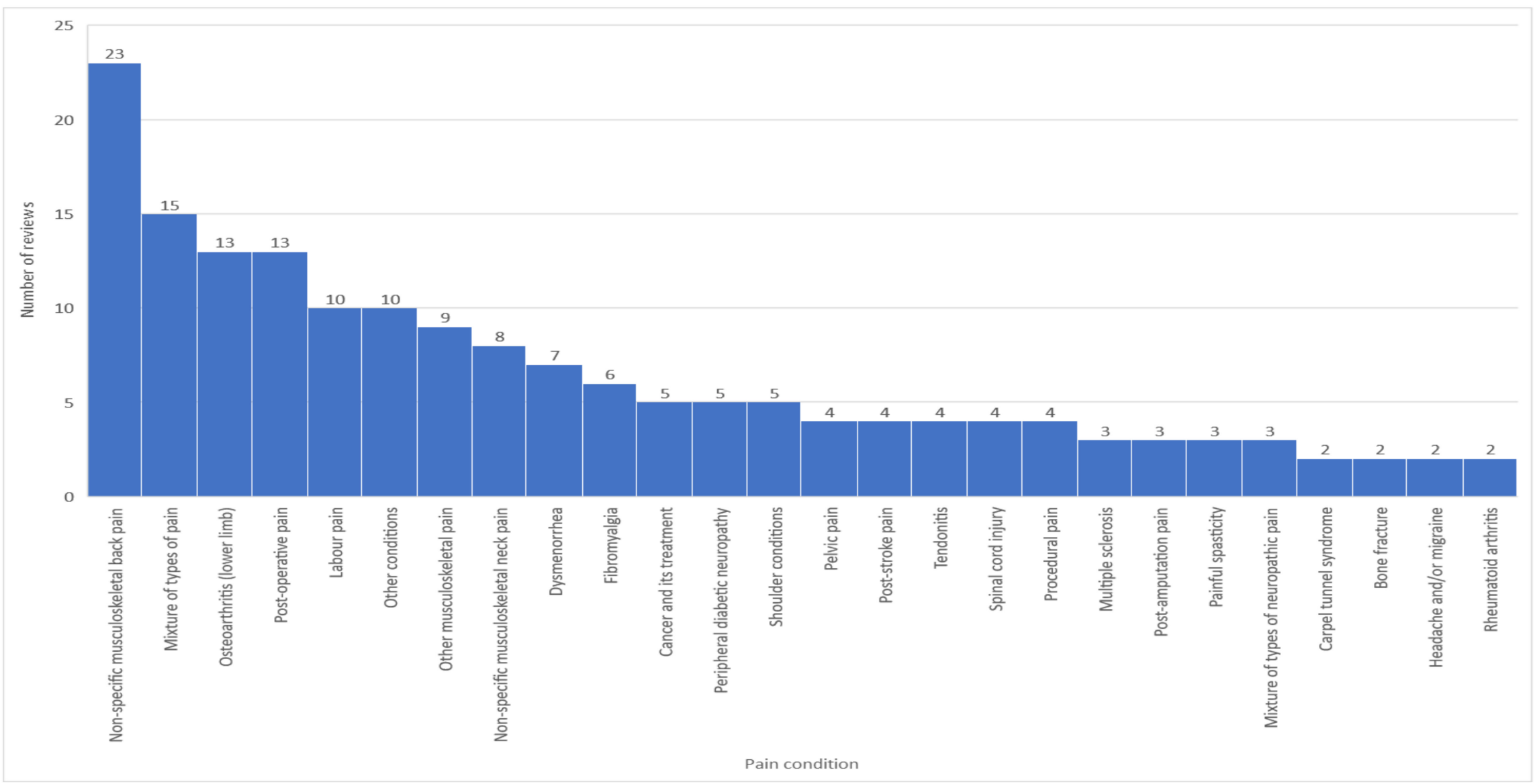

(c)

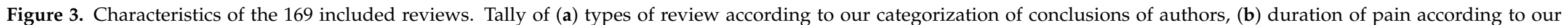
categorization of conclusions of authors, and (c) pain condition. 


\subsubsection{Overviews of Systematic Reviews}

There were eight reports of overviews of systematic reviews, of which two focussed solely on TENS [6,24], and two were published by Cochrane [6,25]. There were five overviews on chronic pain (two on a mixture of pain conditions, two on osteoarthritis of the knee, and one on cancer pain), one overview on acute pain (labour pain), one overview on acute and chronic cancer pain, and one on non-specific neck pain of uncertain duration. None of the overviews conducted a meta-analysis of pooled data.

\subsubsection{Hybrid Reviews}

There were seven reports of hybrid reviews of clinical studies and systematic reviews, none of which focused solely on TENS nor were published by Cochrane. There were two hybrid reviews on chronic pain (non-specific low back pain and post stroke pain), three on acute pain (dysmenorrhea), and two on both acute and chronic pain (non-specific back pain and a variety of types of pain). None of the hybrid reviews conducted a meta-analysis of pooled data.

\subsubsection{Systematic Reviews}

There were 154/169 reports of systematic reviews; 56 reviews focused solely on TENS and 98 evaluated multiple treatments including TENS. There were 38 systematic reviews published by Cochrane. There were 77 systematic reviews on chronic pain, 42 on acute pain, 22 on both acute and chronic pain and 13 on pain of uncertain duration. The majority of systematic reviews were conducted on non-specific musculoskeletal pain $(n=40)$, of which non-specific back pain was most common $(n=21)$. A tally of the meta-analyses for all outcomes and for pain intensity continuous data is shown in Figure 4. Generally, less than half of the systematic reviews included a meta-analysis of pooled data and when they did, they meta-analysed pain intensity continuous data.

\subsubsection{Meta-Analyses}

There were 49 systematic reviews that included a meta-analysis that pooled data from at least two clinical studies; 30 were within systematic reviews that focused solely on TENS and 19 were within reviews of a variety of treatments. There were eight metaanalyses reported as part of a Cochrane review. There were 27 meta-analyses for chronic pain conditions, 16 for acute pain, and six for both acute and chronic. The majority of meta-analyses were for non-specific musculoskeletal pain $(n=13)$ of which 12 were for back pain. There were seven meta-analyses of osteoarthritis, six for post-operative pain, four for labour pain and four for various types of pain (Figure 4).

\section{Characteristics of the Analysis of Pain Intensity: Continuous Data}

There were 37 analyses that estimated effect size for pain intensity from continuous data (i.e., visual analogue scales or numerical rating scales). The remaining 12 meta-analyses estimated effect sizes for pain intensity as dichotomous outcomes (e.g., relative risk, risk ratio), or analysed other pain outcomes (e.g., analgesic consumption or pain free days), or unclear reporting made it impossible to ascertain the analytical methodology.

Two of the meta-analyses that did not estimate effect size for pain intensity from continuous data met our criteria for sufficient data to judge efficacy for other outcomes. Bjordal et al. [11] pooled data from 1350 participant and found a significant mean reduction in analgesic consumption after TENS to be $26.5 \%$ (range $6 \%$ to $51 \%$ ) when compared with placebo. Thuvarakan et al. [26] conducted a responder analysis of pooled data from 11 studies evaluating TENS for labour pain with 700 participants receiving TENS and 626 receiving a control (placebo) intervention. Thuvarakan et al., calculated the risk ratio for participants experiencing moderate $(\geq 30 \%)$ or a strong reduction in pain intensity $(\geq 50 \%)$ as $1.52(95 \% \mathrm{CI}, 1.35,1.70)$ in favour of TENS. 


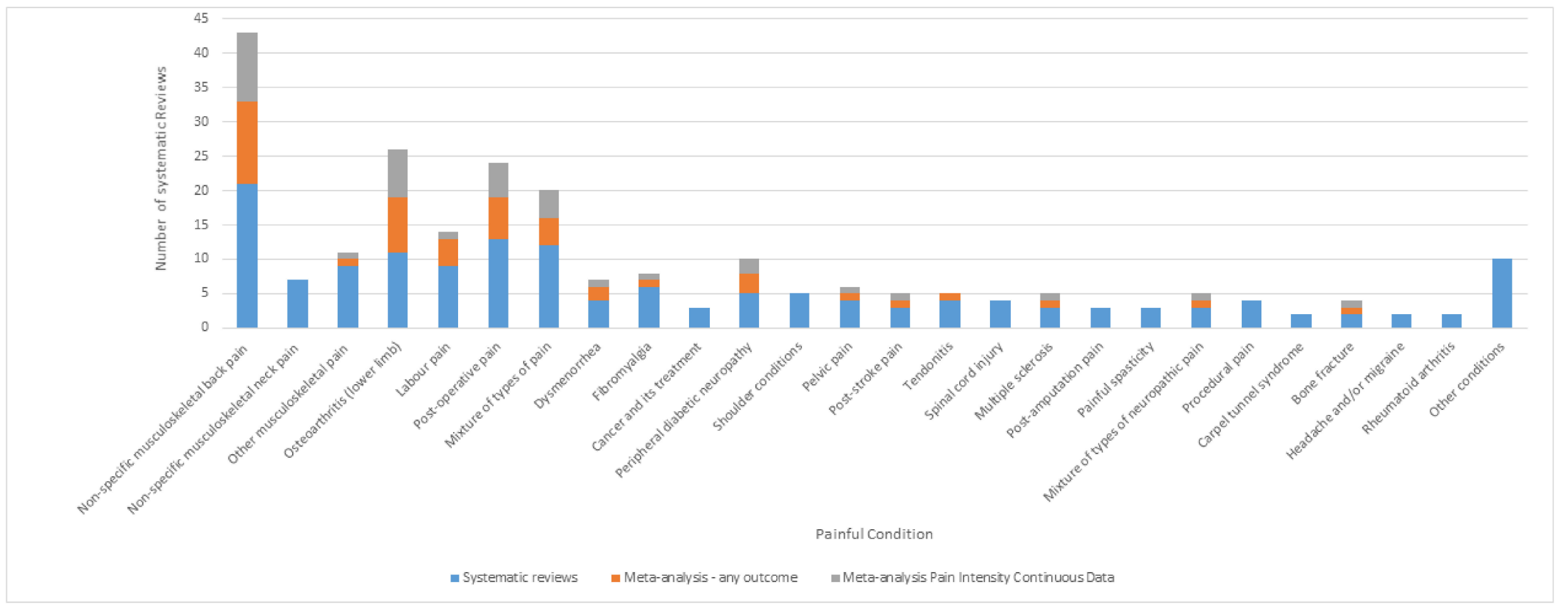

Figure 4. Tally of systematic reviews and meta-analyses for any outcome and for pain intensity (continuous data) according to pain condition $(n=154)$. 
Of the 37 meta-analyses of pain intensity (continuous data), 10 were for back pain, seven for osteoarthritis, five for post-operative pain, two for peripheral diabetic neuropathy, one for labour pain, and four for a mixture of types of pain (Figure 4).

The mean \pm SD number of studies included in the 37 meta-analyses of pain intensity from continuous data was $5.73+4.87$ (minimum $=$ two studies, maximum $=28$ studies, $n=37$ analyses). There were seven reports that did not state the sample size of pooled data entered into the meta-analysis. The mean \pm SD total sample of pooled data was $278 \pm 281$ participants (minimum $=42$, maximum $=1692, n=30$ analyses). Only one metaanalysis pooled data from at least 500 participants events; 18 analyses pooled data from 499 to 200 participants; and 11 analyses pooled fewer than 200 participants (Figure 5).

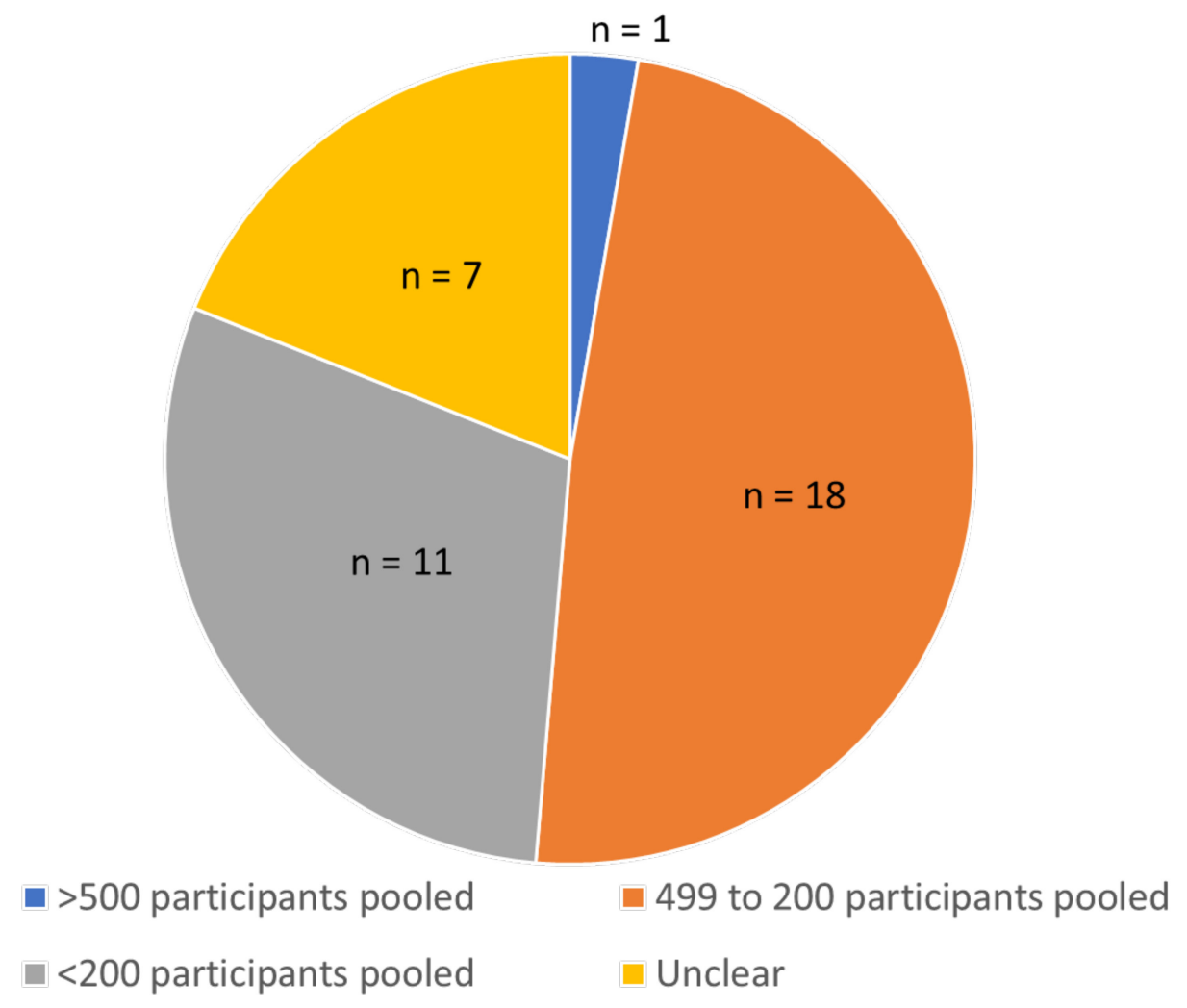

Figure 5. Tally of the size of the total sample of pooled data points in meta-analyses of pain intensity continuous data $(n=37)$.

Of the 37 analyses that estimated effect size for pain intensity from continuous data, 32 compared with a 'control' group which was generally placebo TENS, two compared TENS with standard of care, one compared TENS with interferential therapy, and two did not include a comparator intervention (i.e., they were effect size estimates for pre-post only) (Figure 6).

Of the 35 analyses of TENS versus a comparator, 21 calculated SMD and 14 calculated MD (Figure 7) and 15 calculated effect size as absolute difference (i.e., difference in pain intensity at a single time point during or post TENS), 15 as relative difference (i.e., difference in pain intensity during or post TENS as a change from pre-intervention baseline), and five reports were unclear (Figure 7).

There were 18 analyses reporting standardised mean difference (SMD) for TENS versus a control intervention of a placebo/routine care. Of these, 10 calculated SMD as the change in pain intensity during or post TENS compared with pre-intervention baseline (i.e., relative to baseline), five calculated SMD as a difference in pain intensity at a single time point during or post TENS (i.e., absolute difference), and three were unclear about which method was used. 


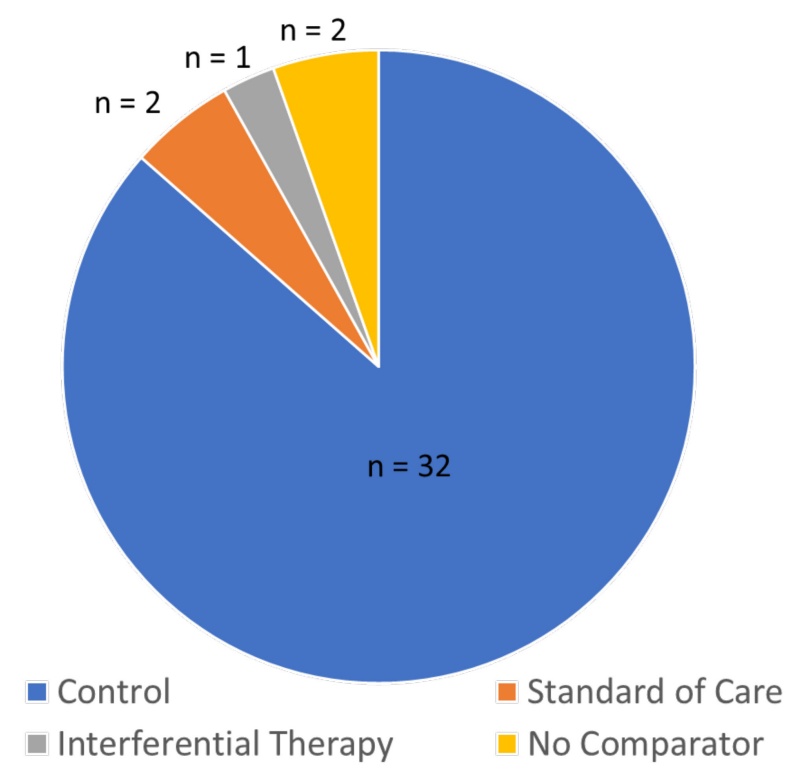

Figure 6. Tally of comparators in meta-analyses of pain intensity continuous data $(n=37)$.

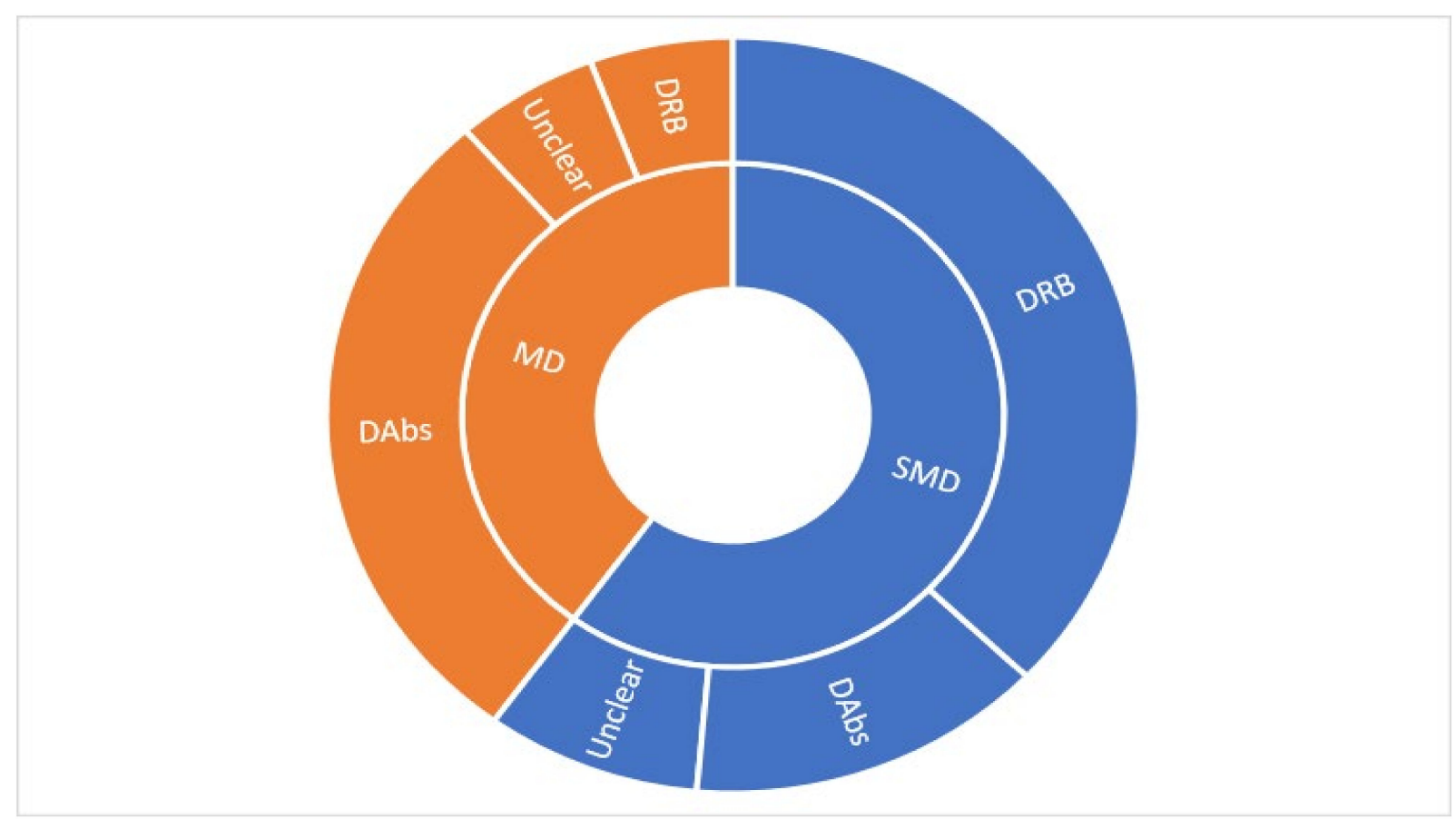

Figure 7. Characteristics of the 35 analyses of pain intensity (continuous data) versus a comparator. Inner ring: Tally of type of effect size estimate (SMD = standardised mean difference, $\mathrm{MD}=$ mean difference). Outer ring: Tally of type of outcome (DAbs = absolute difference between groups, $\mathrm{DRB}=$ relative difference between groups i.e., difference in change from baseline).

We explored the consistency of inclusion of studies in meta-analyses by identifying studies included in the four reviews on non-specific low back pain published within the previous 10 years (Table 1). There was inconsistency in both the inclusion of studies and in whether study data was extracted for meta-analysis. Only one primary study was included in all reviews Topuz et al. [27]. There were instances of studies being included in some reviews but not others; and instances of pain intensity (continuous) data being extracted from studies in some reviews but not others. 


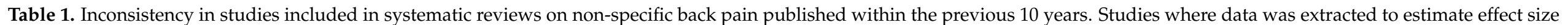
estimates for pain intensity (continuous data) in previous systematic reviews are identified.
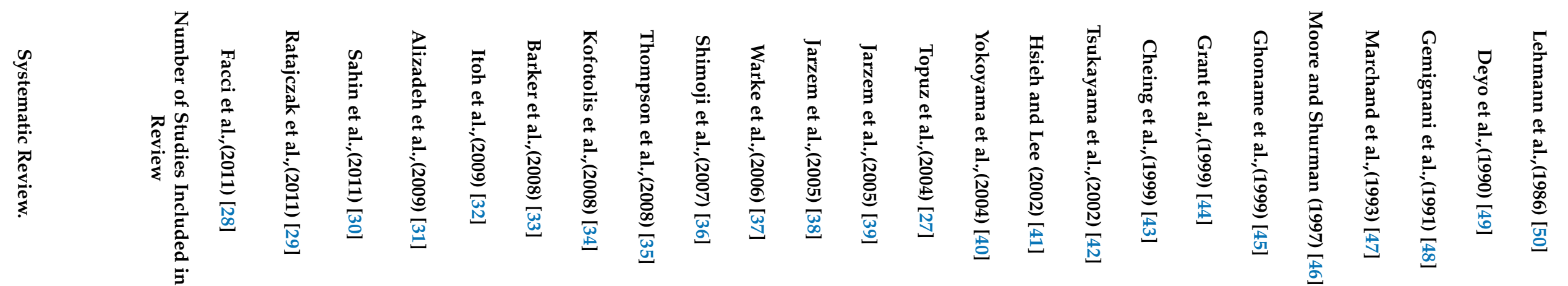

\begin{tabular}{ccccccc}
\hline Resende et al. [51] & 9 & I & & I & I \\
Wu et al. [14] & 12 & & & & \\
& & I & I & \\
Jauregui et al. [52] & 13 & DE & DE & \\
$\begin{array}{c}\text { Van Middelkoop et al. } \\
\text { [53] }\end{array}$ & 7 & N/A & N/A & N/A \\
\hline
\end{tabular}
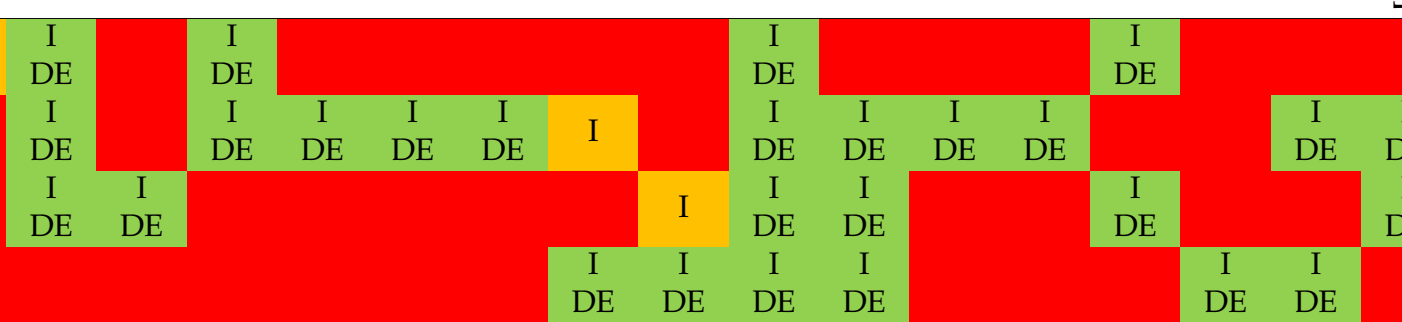

$\mathrm{DE}$

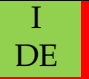

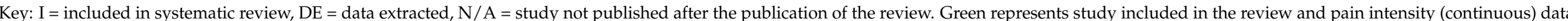

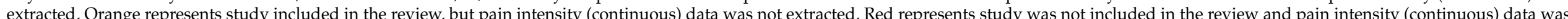

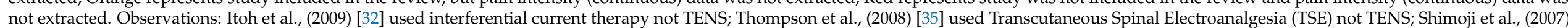

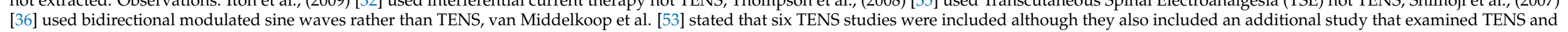
categorised under exercise interventions rather than TENS intervetions. 


\subsection{Analysis of Outcomes Irrespective of Condition}

\subsubsection{All Included Reviews}

The tally of the conclusions of authors of all of the included reviews found that TENS may be efficacious in 69/169 reviews, evidence of no efficacy in 13/169 reviews, and inconclusive evidence in 87/169 reviews (Figure 3a). However, when judged against our criteria, 165/169 reviews had insufficient data to make a judgement (Figure 8). There were no reviews with sufficient data to support evidence of no benefit, no reviews with sufficient data to support evidence that was conflicting (inconclusive) and 3/169 reviews with sufficient data to support evidence of benefit $[10,11,26]$

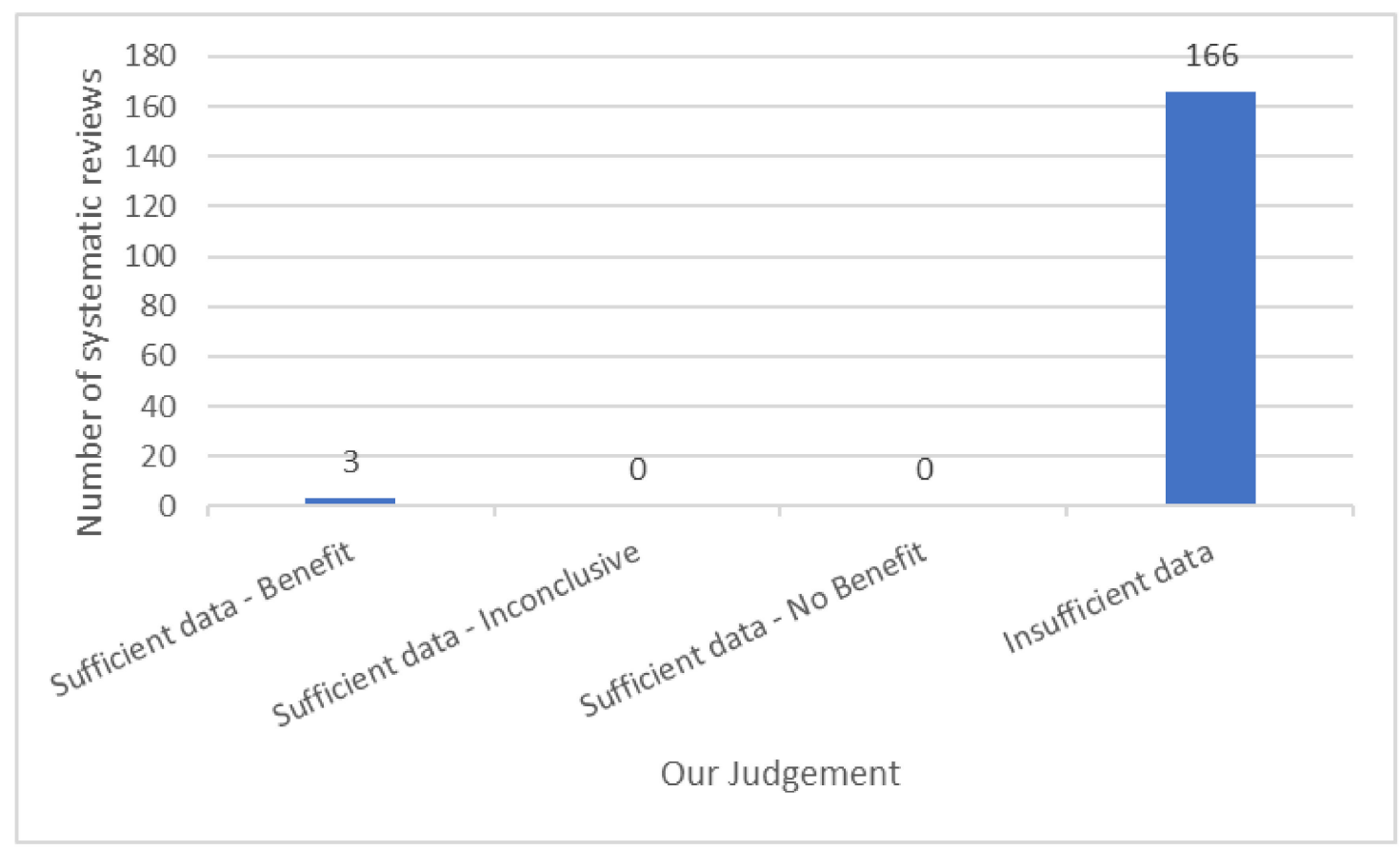

Figure 8. Tally of our judgement of outcome based on our criteria for sufficient data for all reviews $(n=169)$.

\subsubsection{Overviews of Systematic Reviews}

The tally of the conclusions of authors of the eight overviews found evidence that TENS may be efficacious in three reports; osteoarthritis of the knee $[54,55]$ and non-specific neck pain [56]. The authors of five overviews judged evidence to be inconclusive. When judged against our criteria, there were no overviews with sufficient data to make a judgement.

\subsubsection{Hybrid Reviews}

The tally of the conclusions of authors of the seven hybrid reviews found evidence that TENS may be efficacious in four reports; paretic upper limb of stroke survivors [57] and dysmenorrhea [58-60]. The authors of one hybrid review concluded that evidence suggested no benefit (for non-specific back pain) [61]. When judged against our criteria, there were no hybrid reviews with sufficient data to make a judgement.

\subsubsection{Systematic Reviews}

The tally of the conclusions of authors of the 154 systematic reviews found evidence that TENS may be efficacious in 62 reports, evidence of no benefit in 12 reports and inconclusive evidence in 80 reports (Figure 9). 


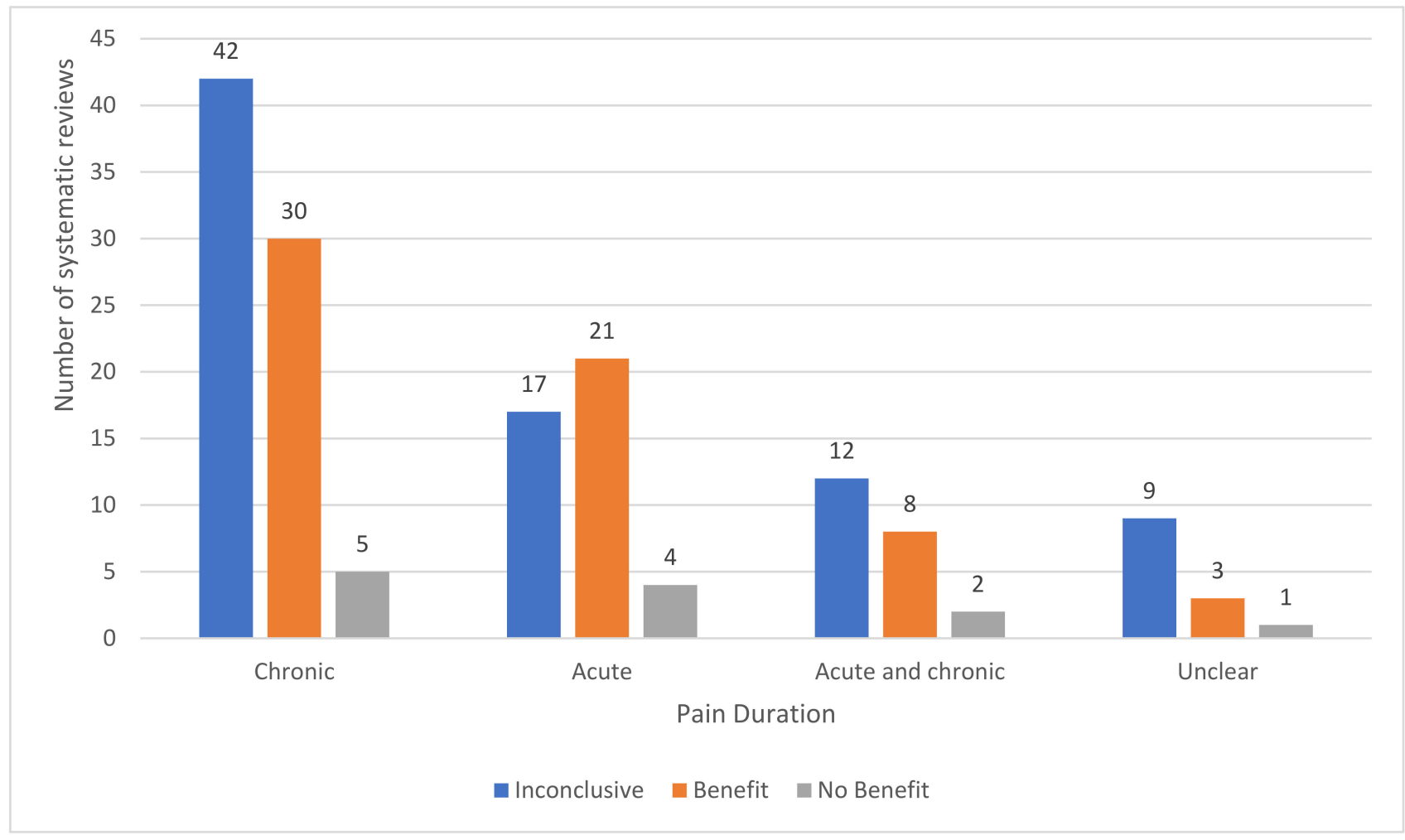

Figure 9. Conclusions of systematic reviews. Tally of our categorisation of conclusions of authors according to pain duration $(n=154)$.

The tally of the conclusions of authors of systematic reviews were inconclusive across the majority of pain conditions except for post-operative pain, osteoarthritis and peripheral diabetic neuropathy where the majority of authors judged evidence to tend toward benefit (Figure 10). However, when judged against our criteria, there were 151 systematic reviews with insufficient data and/or quality to make judgements about efficacy. The three systematic reviews with sufficient data provided evidence that TENS reduced chronic musculoskeletal pain [10], labour pain [26] and post-operative analgesic consumption [11].

\subsubsection{Meta-Analyses TENS versus Control for Pain Intensity (Continuous Data)}

It was difficult to compare effect size estimates between reviews due to inconsistency in analysis methodologies.

Standardised mean differences are shown in Table 2. One of the SMDs did not include a comparator (i.e., pre-post TENS estimate for chronic back pain [52]). Visual inspection of the 19 SMD estimates versus a comparator revealed one idiosyncratic SMD estimate by Brosseau et al. [62] who reported an unusually high SMD relative to baseline for chronic low back pain (i.e., SMD $=-4.32(95 \% \mathrm{CI}-10.36,-1.72)$ in favour of TENS). The remaining 18 estimates of SMD versus a comparator lay between -1.65 and 1.27; there were no noticeable differences in the magnitude of absolute SMDs and SMDs relative to baseline.

There were 12 of 19 SMDs where confidence intervals did not bisect the line of no difference suggesting greater efficacy for TENS compared with the comparator, irrespective of whether calculated as absolute differences or differences relative to baseline.

Inconsistency in analytical approaches made it difficult to compare SMD estimates across most pain conditions. All SMDs for pain associated with osteoarthritis and for post-operative pain had upper limit confidence intervals that were in favour of TENS (i.e., did not bisect the line of no difference). Only one of the four SMDs relative to baseline for chronic back pain had an upper confidence interval that was in favour of TENS (i.e., did not bisect the line of no difference). 


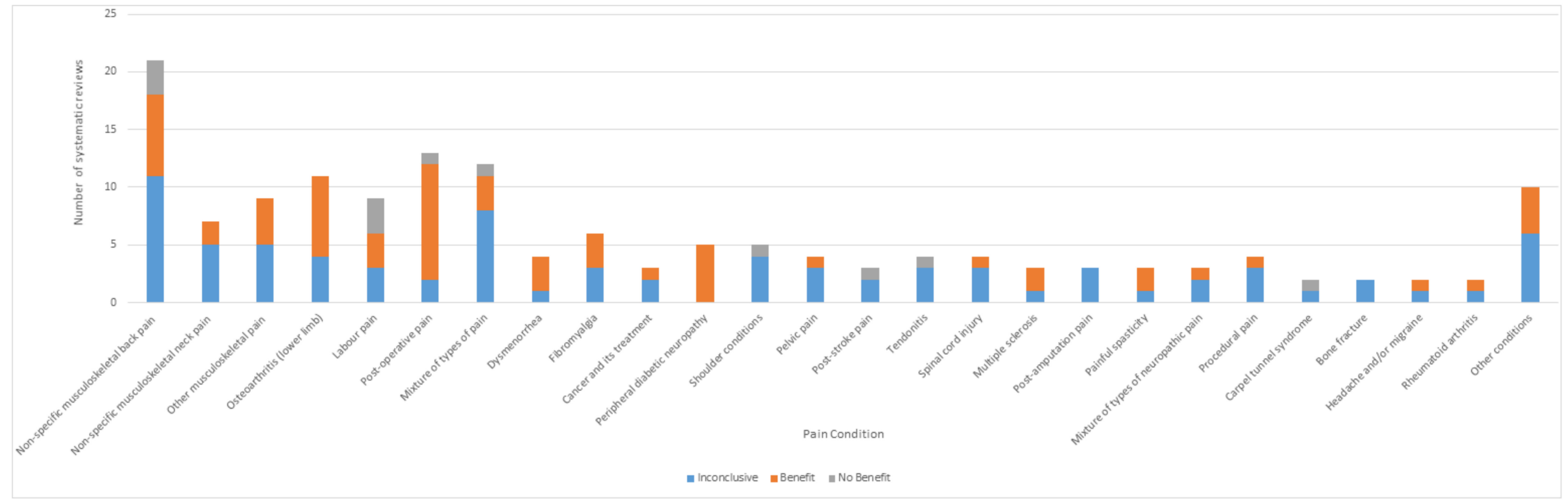

Figure 10. Conclusions of systematic reviews. Tally of our categorisation of conclusions of authors according to pain condition $(n=154)$. 
Mean differences are shown in Table 3. All estimates of mean differences were against a comparator, although it was not possible to estimate data from some reports because findings were presented graphically without numerical equivalents. Estimates of MD versus a comparator lay between -26.3 and 0.59 relative to baseline and between -44.41 and 6.13 absolute difference on a $100 \mathrm{~mm}$ scale; there were no noticeable differences in the magnitude of absolute SMDs and SMDs relative to baseline.

There were 9/11 MDs where confidence interval did not bisect the line of no difference suggesting greater efficacy for TENS compared with the comparator, irrespective of whether calculated as absolute differences or differences relative to baseline. Inconsistency in analytical approaches made it difficult to compare MD estimates across most pain conditions.

A summary of effect size estimates grouped according to pain condition are shown in Figure 11a,b. Reporting of meta-analyses methods and findings was sometimes superficial, unclear and inconsistent. There were instances of authors presenting forest plots labelled as mean differences but stating standardised mean differences in figure captions and uncertainty whether MDs were representing scores on 100- or 10-unit scales.

There was one instance of inconsistency in reporting. Dowswell et al. [22] reported a SMD for the difference in pain intensity during/post between TENS and placebo/routine care of $-1.01(95 \%$ CI $-3.0,0.97)$ from data pooled from two studies (TENS $=143$, placebo $=156$, random effects model). In an updated report published two years later which was excluded from our review, the same data was pooled but reported the SMD was stated to be $-0.16(95 \% \mathrm{CI},-0.39,0.07)$ possibly because they had calculated SMD using a fixed-effects rather than random effects model [23].

\subsection{Analysis of Outcomes Specific for Specific Pain Conditions}

In the following section we appraise outcomes according to specific pain conditions.

\subsubsection{Mixtures of Painful Conditions (15 Reviews)}

We included 10 reviews that evaluated TENS for a mixture of types of chronic pain, three reviews that evaluated TENS for a mixture of types of acute pain, and two reviews that evaluated TENS for a mixture of types of acute and chronic pain (Table 4).

\section{Mixtures of Chronic Pain Conditions}

There were two overviews of systematic reviews. In 2008, Claydon and Chesterton [24] conducted a review of six systematic reviews and suggested that three of these reviews provided evidence that TENS was superior to placebo for any type of chronic pain; and two of the six reviews found that high intensity TENS was more effective than low intensity TENS, when compared with placebo. Claydon and Chesterton [24] extracted information from 24 trials that compared TENS with placebo and judged 14 of these to show positive outcome, of which eight were deemed to be of high quality. In 2019, a comprehensive overview Cochrane overview of eight Cochrane reviews published in 2019 evaluated the efficacy of TENS for any type of chronic pain [6]. Gibson et al. [6] judged evidence to be inconclusive based on a descriptive analysis of 51 RCTs (with 2895 participants). The reviewers were reluctant to meta-analyse data due to methodological and clinical heterogeneity. Readers are directed to this overview as a comprehensive appraisal of evidence to date. 
Table 2. Standardised mean differences reported in reviews and calculated from pooled data for pain intensity for continuous data.

\begin{tabular}{|c|c|c|c|c|c|c|c|c|c|c|}
\hline Reference & Title & Condition & Comparison & $\begin{array}{c}\text { No. } \\
\text { Pooled } \\
\text { Studies }\end{array}$ & $\begin{array}{c}\text { Number of Participants } \\
\text { Pooled TENS }\end{array}$ & $\begin{array}{l}\text { Number of Participants } \\
\text { Pooled Comparison }\end{array}$ & SMD & $\begin{array}{l}\text { Lower } \\
\text { CI }\end{array}$ & Upper & Comment \\
\hline \multicolumn{11}{|c|}{ Standardised Mean Difference during or post TENS relative to baseline } \\
\hline $\begin{array}{l}\text { Wu et al., } \\
2018[14]\end{array}$ & $\begin{array}{l}\text { Literature Review and } \\
\text { Meta-Analysis of } \\
\text { Transcutaneous Electrical } \\
\text { Nerve Stimulation in } \\
\text { Treating Chronic Back Pain }\end{array}$ & $\begin{array}{l}\text { Chronic low } \\
\text { back pain }\end{array}$ & Control & 9 & TENS $=238$ & Control $=159$ & -0.2 & -0.58 & 0.18 & $\begin{array}{l}\text { NOTE: Data also presented for } \\
\text { SMD TENS vs. other nerve } \\
\text { stimulation therapies }=0.86 \\
(95 \% \text { CI } 0.15,1.57), \text { TENS }=122 \\
\text { NST }=105,5 \text { trials }\end{array}$ \\
\hline $\begin{array}{l}\text { Keller et al., } \\
2007 \text { [63] }\end{array}$ & $\begin{array}{l}\text { Effect sizes of non-surgical } \\
\text { treatments of non-specific } \\
\text { low-back pain }\end{array}$ & $\begin{array}{l}\text { Chronic low } \\
\text { back pain }\end{array}$ & Placebo & 2 & $\begin{array}{c}\text { Not reported } \\
\text { Total sample }=114\end{array}$ & $\begin{array}{c}\text { Not reported } \\
\text { Total sample }=114\end{array}$ & -0.19 & -0.51 & 0.13 & $\begin{array}{l}\text { NOTE: of the } 2 \text { studies one } \\
\text { recorded improvement of pain } \\
\text { on a } 6 \text { point Likert scale and the } \\
\text { other pain intensity VAS }\end{array}$ \\
\hline $\begin{array}{l}\text { Philadelphia } \\
\text { Panel 2001 } \\
\text { [64] }\end{array}$ & $\begin{array}{c}\text { Philadelphia Panel } \\
\text { Evidence-Based Clinical } \\
\text { Practice Guidelines on } \\
\text { Selected Rehabilitation } \\
\text { Interventions for Low Back } \\
\text { Pain }\end{array}$ & $\begin{array}{l}\text { Chronic low } \\
\text { back pain }\end{array}$ & Unclear & 3 & Not reported & Not Reported & $-0,2$ & $-0,4$ & 0.1 & $\begin{array}{l}\text { NOTE: MA for chronic back pain } \\
\text { only. SMD reported but not trial } \\
\text { arm sample sizes }\end{array}$ \\
\hline $\begin{array}{l}\text { Brosseau } \\
\text { et al., } 2002 \\
{[62]}\end{array}$ & $\begin{array}{l}\text { Efficacy of the } \\
\text { transcutaneous electrical } \\
\text { nerve stimulation for the } \\
\text { treatment of chronic low } \\
\text { back pain-A } \\
\text { meta-analysis. }\end{array}$ & $\begin{array}{l}\text { Chronic low } \\
\text { back pain }\end{array}$ & Placebo & 3 & TENS $=89$ & Placebo $=82$ & -4.32 & -10.36 & -1.72 & $\begin{array}{l}\text { NOTE: We used data from } \\
\text { Figure } 1 \text { of the report at } 1 \text { month }\end{array}$ \\
\hline $\begin{array}{l}\text { Stein et al., } \\
2013 \text { [65] }\end{array}$ & $\begin{array}{l}\text { Electrical stimulation and } \\
\text { electromagnetic field use } \\
\text { in patients with diabetic } \\
\text { neuropathy: systematic } \\
\text { review and meta-analysis }\end{array}$ & $\begin{array}{l}\text { Diabetic } \\
\text { neuropathy }\end{array}$ & Sham & 5 & $\mathrm{TENS}=76$ & Sham TENS $=57$ & -0.44 & -0.79 & -0.09 & \\
\hline $\begin{array}{l}\text { Jin et al., } \\
2010[66]\end{array}$ & $\begin{array}{l}\text { Effect of transcutaneous } \\
\text { electrical nerve stimulation } \\
\text { on symptomatic diabetic } \\
\text { peripheral neuropathy: A } \\
\text { meta-analysis of } \\
\text { randomized controlled } \\
\text { trials }\end{array}$ & $\begin{array}{l}\text { Diabetic } \\
\text { neuropathy }\end{array}$ & Sham & 2 & TENS $=26$ & Sham TENS $=16$ & -1.65 & -4.02 & 0.73 & $\begin{array}{l}\text { NOTE: Forest plot has multiple } \\
\text { counts from the same study. } \\
\text { Figure within the report } \\
\text { calculated an overall SMD with } \\
\text { data extracted from different } \\
\text { time points from the same study. } \\
\text { We have extracted data at } \\
12 \text { weeks because other SMDs } \\
\text { represented } 1 \text { study e.g., at } \\
4 \text { weeks SMD TENS vs. } \\
\text { sham }=-5.37 \text { (95\%CI }-6.97 \\
\text {-3.77) pain intensity TENS = 18 } \\
\text { sham = 13 }\end{array}$ \\
\hline
\end{tabular}


Table 2. Cont.

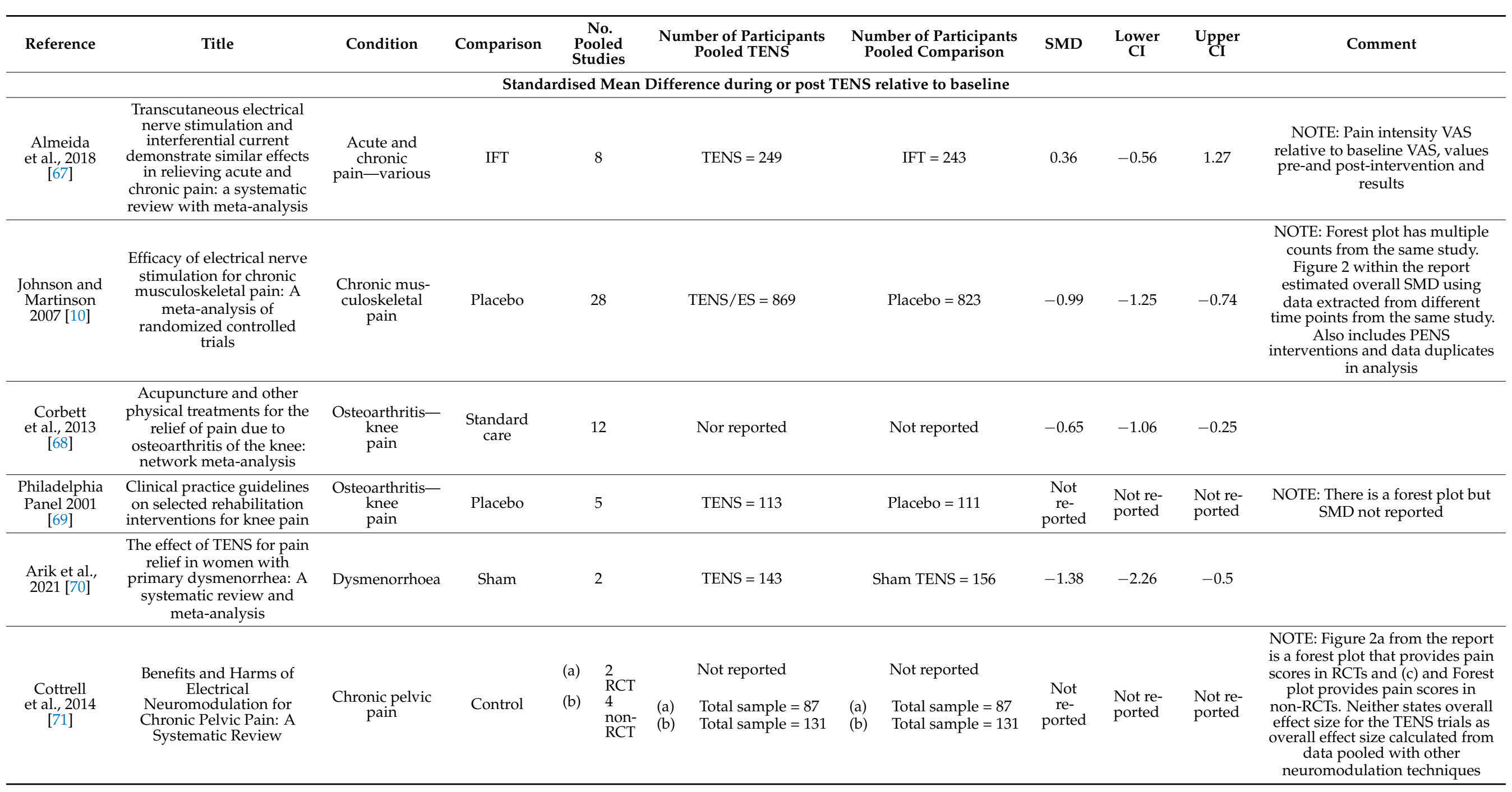


Table 2. Cont.

\begin{tabular}{|c|c|c|c|c|c|c|c|c|c|c|}
\hline Reference & Title & Condition & Comparison & $\begin{array}{c}\text { No. } \\
\text { Pooled } \\
\text { Studies }\end{array}$ & $\begin{array}{c}\text { Number of Participants } \\
\text { Pooled TENS }\end{array}$ & $\begin{array}{l}\text { Number of Participants } \\
\text { Pooled Comparison }\end{array}$ & SMD & $\begin{array}{l}\text { Lower } \\
\text { CI }\end{array}$ & $\begin{array}{l}\text { Upper } \\
\text { CI }\end{array}$ & Comment \\
\hline \multicolumn{11}{|c|}{ Standardised Mean Difference during or post TENS (absolute difference) } \\
\hline $\begin{array}{l}\text { Price and } \\
\text { Pandyan } \\
2000[72]\end{array}$ & $\begin{array}{l}\text { Electrical stimulation for } \\
\text { preventing and treating } \\
\text { post-stroke shoulder pain }\end{array}$ & $\begin{array}{l}\text { Post-stroke- } \\
\text { shoulder }\end{array}$ & Control & 2 & $\mathrm{TENS}=46$ & Control $=38$ & -0.1 & -0.54 & 0.34 & $\begin{array}{l}\text { NOTE: Extracted Electrical } \\
\text { Stimulation (Functional electrical } \\
\text { stimulation or TENS) vs. sham. } \\
\text { There was only } 1 \text { SMD TENS vs. } \\
\text { control }=-0.44 \text { (CI }-1.05 \\
-0.16 \text { ), TENS }=26 \text {, control }=18\end{array}$ \\
\hline $\begin{array}{l}\text { Zimpel } \\
\text { et al., 2020 } \\
{[73]}\end{array}$ & $\begin{array}{l}\text { Complementary and } \\
\text { alternative therapies for } \\
\text { post-caesarean pain }\end{array}$ & $\begin{array}{l}\text { Postoperative } \\
\text { pain- } \\
\text { caesarean }\end{array}$ & Placebo & 3 & TENS $=119$ & Control = 119 & -1.1 & -1.37 & -0.82 & $\begin{array}{l}\text { SMD TENS }(+ \text { analgesia }) \text { vs. } \\
\text { placebo }(+ \text { analgesia })=-1.10(\mathrm{CI} \\
-1.37,-0.82)\end{array}$ \\
\hline $\begin{array}{l}\text { Li and Song } \\
2021[74]\end{array}$ & $\begin{array}{l}\text { Transcutaneous electrical } \\
\text { nerve stimulation for } \\
\text { postoperative pain control } \\
\text { after total knee } \\
\text { arthroplasty: A } \\
\text { meta-analysis of } \\
\text { randomized controlled } \\
\text { trials }\end{array}$ & $\begin{array}{l}\text { Postoperative } \\
\text { pain-knee } \\
\text { arthroplasty }\end{array}$ & Control & 5 & TENS $=136$ & Control = 131 & -0.26 & -0.44 & -0.08 & \\
\hline $\begin{array}{l}\text { Zhu et al., } \\
2017 \text { [75] }\end{array}$ & $\begin{array}{l}\text { Effect of Transcutaneous } \\
\text { Electrical Nerve } \\
\text { Stimulation for Pain } \\
\text { Control after Total Knee } \\
\text { Arthroplasty: A Systematic } \\
\text { Review and Meta-Analysis }\end{array}$ & $\begin{array}{l}\text { Postoperative } \\
\text { pain-knee } \\
\text { arthroplasty }\end{array}$ & Control & 2 & TENS $=51$ & Control $=51$ & -0.47 & -0.87 & -0.08 & \\
\hline $\begin{array}{l}\text { Zeng et al., } \\
2015 \text { [76] }\end{array}$ & $\begin{array}{l}\text { Electrical stimulation for } \\
\text { pain relief in knee } \\
\text { osteoarthritis systematic } \\
\text { review and network } \\
\text { meta-analysis }\end{array}$ & $\begin{array}{l}\text { Osteoarthritis- } \\
\text { knee } \\
\text { pain }\end{array}$ & Control & 9 & $\begin{array}{l}\text { Not reported Total } \\
\quad \text { sample }=329\end{array}$ & $\begin{array}{l}\text { Not reported Total } \\
\quad \text { sample }=329\end{array}$ & -0.78 & -1.34 & -0.22 & $\begin{array}{c}\text { NOTE: Used data for SMD } \\
\text { h-TENS vs. control; Also } \\
\text { reported: } h \text {-TENS vs. } \\
\text { IFC }=-0.14(\mathrm{CI}-1,0.74) \text {, total } \\
\text { sample }=56,1 \text { trial; } \mathrm{h}-\mathrm{TENS} \text { vs. } \\
\text { l-TENS }=-0.64(\mathrm{CI}-1.53,0.32), \\
\text { total sample }=75.2 \text { trials; } 1 \text {-TENS } \\
\text { vs. control }=-0.14(\mathrm{CI}-1.03, \\
\text { 0.78), total sample }=123,3 \text { trials. } \\
\text { This was a network } \\
\text { meta-analysis. }\end{array}$ \\
\hline $\begin{array}{l}\text { Dowswell } \\
\text { et al., } 2009 \\
\text { [22] }\end{array}$ & $\begin{array}{c}\text { Transcutaneous electrical } \\
\text { nerve stimulation (TENS) } \\
\text { for pain management in } \\
\text { labour (Review) }\end{array}$ & Labour pain & $\begin{array}{l}\text { Placebo/routine } \\
\text { care }\end{array}$ & 2 & TENS $=143$ & $\begin{array}{l}\text { Placebo } / \text { routine } \\
\quad \text { care }=156\end{array}$ & -1.01 & -3.0 & 0.97 & $\begin{array}{l}\text { NOTE: This is using the same } \\
\text { study data as (Bedwell et al., } \\
\text { 2011) but gets a different SMD. } \\
\text { This used a random effects model }\end{array}$ \\
\hline
\end{tabular}


Table 2. Cont.

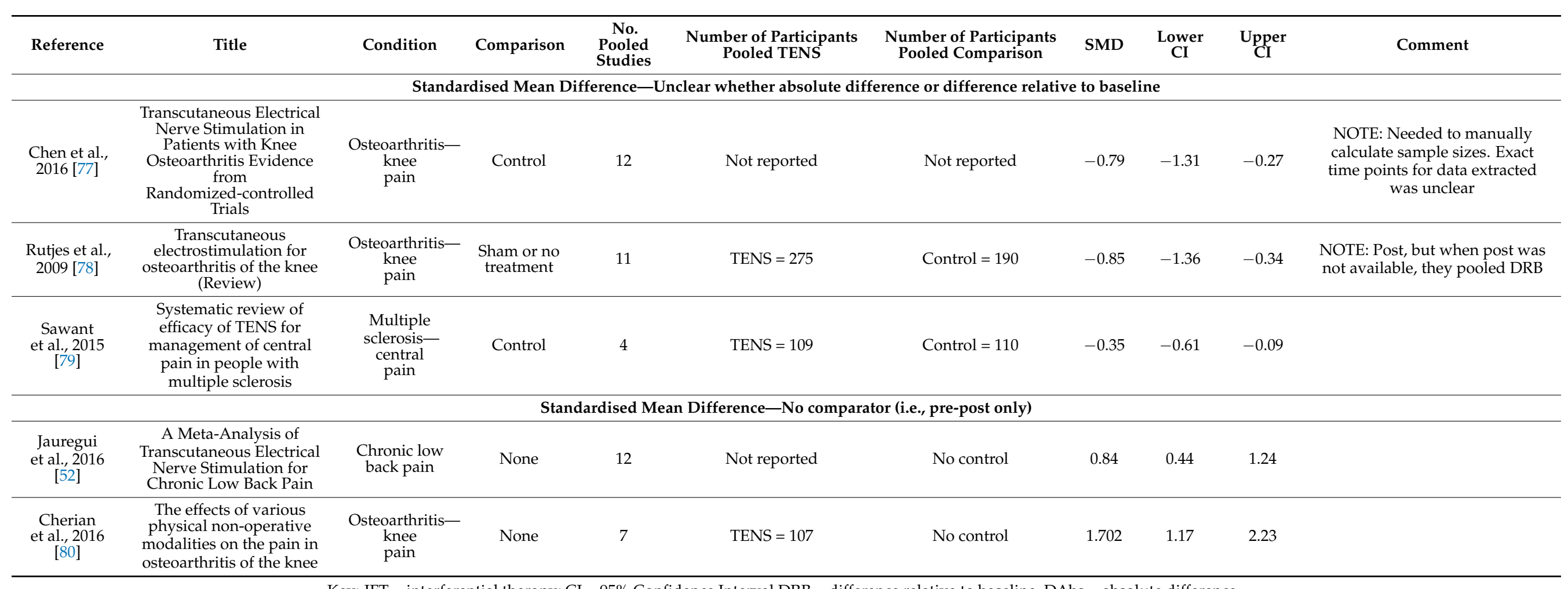

Key: IFT = interferential therapy; CI = 95\% Confidence Interval DRB = difference relative to baseline, $\mathrm{DAbs}=$ absolute difference. 
Table 3. Mean differences reported in reviews and calculated from pooled data for pain intensity for continuous data.

\begin{tabular}{|c|c|c|c|c|c|c|c|c|c|c|c|}
\hline Reference & Title & Condition & Comparison & $\begin{array}{l}\text { No. } \\
\text { Pooled } \\
\text { Studies }\end{array}$ & $\begin{array}{l}\text { Number of } \\
\text { Participants } \\
\text { Pooled TENS }\end{array}$ & $\begin{array}{l}\text { Number of } \\
\text { Participants } \\
\text { Pooled } \\
\text { Comparison } \\
\end{array}$ & Measure & MD & $\begin{array}{l}\text { Lower } \\
\text { CI }\end{array}$ & $\begin{array}{l}\text { Upper } \\
\text { CI }\end{array}$ & Comment \\
\hline \multicolumn{12}{|c|}{ Mean Difference during or post TENS relative to baseline } \\
\hline $\begin{array}{l}\text { Bjordal et al., } \\
2007 \text { [82] }\end{array}$ & $\begin{array}{l}\text { Short-term efficacy of } \\
\text { physical interventions in } \\
\text { osteoarthritic knee pain. A } \\
\text { systematic review and } \\
\text { meta-analysis of } \\
\text { randomised } \\
\text { placebo-controlled trials. }\end{array}$ & $\begin{array}{l}\text { Osteoarthritis- } \\
\text { knee } \\
\text { pain }\end{array}$ & Placebo & 7 & $\begin{array}{c}\text { TENS }(\text { IFT })= \\
163\end{array}$ & Placebo $=114$ & $\begin{array}{l}\text { Difference } \\
\text { during/post } \\
\text { TENS relative } \\
\text { to baseline }\end{array}$ & -22.1 & -26.3 & -18.12 & \\
\hline \multicolumn{12}{|c|}{ Mean Difference during or post TENS (absolute difference) } \\
\hline $\begin{array}{l}\text { Johnson et al., } \\
2015 \text { [83] }\end{array}$ & $\begin{array}{l}\text { Transcutaneous electrical } \\
\text { nerve stimulation for acute } \\
\text { pain }\end{array}$ & $\begin{array}{l}\text { Acute pain- } \\
\text { various }\end{array}$ & Placebo & 6 & TENS $=218$ & Placebo 218 & $\begin{array}{c}\text { Absolute } \\
\text { Difference } \\
\text { during/post } \\
\text { TENS } \\
\end{array}$ & -24.6 & -31.79 & -17.4 & \\
\hline $\begin{array}{l}\text { Simpson et al., } \\
2014 \text { [84] }\end{array}$ & $\begin{array}{l}\text { Transcutaneous electrical } \\
\text { nerve stimulation for } \\
\text { relieving acute pain in the } \\
\text { prehospital setting }\end{array}$ & $\begin{array}{l}\text { Acute pain- } \\
\text { various in } \\
\text { prehospital } \\
\text { setting }\end{array}$ & Sham & 4 & TENS $=128$ & $\begin{array}{l}\text { Sham } \\
\text { TENS = } 133\end{array}$ & $\begin{array}{l}\text { Absolute } \\
\text { Difference } \\
\text { during/post } \\
\text { TENS }\end{array}$ & -32.7 & -44.41 & -20.97 & \\
\hline $\begin{array}{l}\text { Binny et al., } \\
2019 \text { [85] }\end{array}$ & $\begin{array}{l}\text { Transcutaneous electric } \\
\text { nerve stimulation (TENS) } \\
\text { for acute low back pain: } \\
\text { systematic review }\end{array}$ & $\begin{array}{l}\text { Acute low } \\
\text { back pain }\end{array}$ & Control & 2 & TENS $=64$ & Control $=65$ & $\begin{array}{l}\text { Absolute } \\
\text { Difference } \\
\text { during/post } \\
\text { TENS } \\
\end{array}$ & -2.75 & -11.63 & 6.13 & \\
\hline $\begin{array}{l}\text { Resende et al., } \\
\quad 2018 \text { [51] }\end{array}$ & $\begin{array}{c}\text { Meta-analysis of } \\
\text { transcutaneous electrical } \\
\text { nerve stimulation for relief } \\
\text { of spinal pain }\end{array}$ & $\begin{array}{l}\text { Chronic } \\
\text { back and/or } \\
\text { neck pain }\end{array}$ & Control & 6 & TENS/IFT 148 & Control $=142$ & $\begin{array}{l}\text { Absolute } \\
\text { Difference } \\
\text { during/post } \\
\text { TENS } \\
\end{array}$ & -9.2 & -17.3 & -1.2 & \\
\hline $\begin{array}{l}\text { Machado et al., } \\
2009 \text { [86] }\end{array}$ & $\begin{array}{c}\text { Analgesic effects of } \\
\text { treatments for non-specific } \\
\text { low back pain: a } \\
\text { meta-analysis of } \\
\text { placebo-controlled } \\
\text { randomized trials }\end{array}$ & $\begin{array}{l}\text { Chronic low } \\
\text { back pain }\end{array}$ & Placebo & 4 & $\begin{array}{l}\text { Not reported } \\
\text { Total sample } \\
\quad 178\end{array}$ & $\begin{array}{l}\text { Not reported } \\
\text { Total sample } 178\end{array}$ & $\begin{array}{l}\text { Absolute } \\
\text { Difference } \\
\text { during/post } \\
\text { TENS }\end{array}$ & $\begin{array}{l}\text { Not } \\
\text { reported }\end{array}$ & $\begin{array}{l}\text { Not } \\
\text { reported }\end{array}$ & $\begin{array}{c}\text { Not } \\
\text { reported }\end{array}$ & $\begin{array}{l}\text { NOTE: Data was pooled } \\
\text { and forest plot presented } \\
\text { without numbers. Effect } \\
\text { size not reported }\end{array}$ \\
\hline
\end{tabular}


Table 3. Cont.

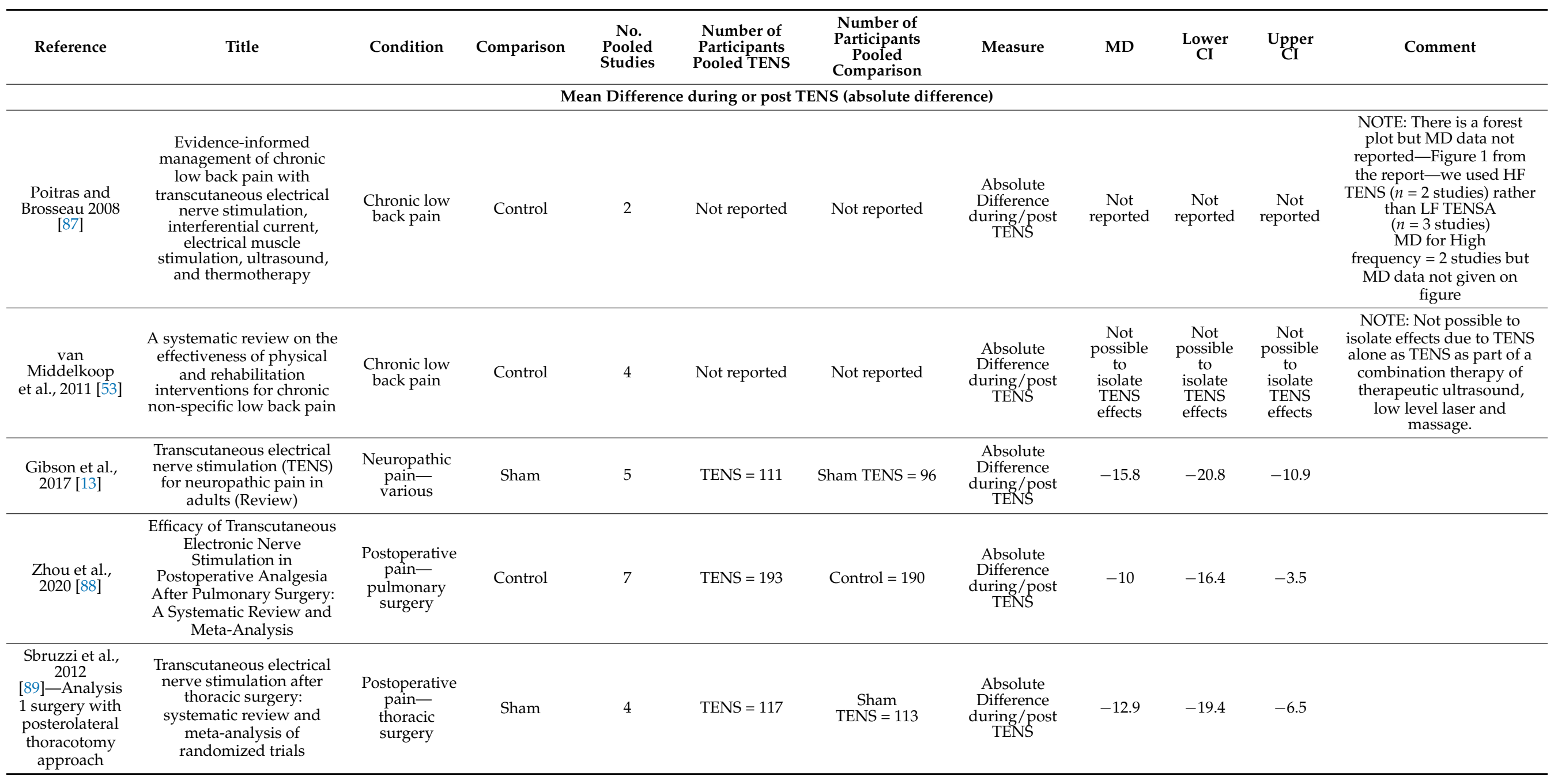


Table 3. Cont.

\begin{tabular}{|c|c|c|c|c|c|c|c|c|c|c|c|}
\hline Reference & Title & Condition & Comparison & $\begin{array}{l}\text { No. } \\
\text { Pooled } \\
\text { Studies }\end{array}$ & $\begin{array}{l}\text { Number of } \\
\text { Participants } \\
\text { Pooled TENS }\end{array}$ & $\begin{array}{l}\text { Number of } \\
\text { Participants } \\
\text { Pooled } \\
\text { Comparison }\end{array}$ & Measure & MD & $\begin{array}{l}\text { Lower } \\
\text { CI }\end{array}$ & Upper & Comment \\
\hline \multicolumn{12}{|c|}{ Mean Difference during or post TENS (absolute difference) } \\
\hline $\begin{array}{l}\text { Sbruzzi et al., } \\
\text { 2012 } \\
\text { [89]-Analysis } \\
2 \text { surgery with } \\
\text { posterolateral } \\
\text { thoracotomy } \\
\text { approach }\end{array}$ & $\begin{array}{l}\text { Transcutaneous electrical } \\
\text { nerve stimulation after } \\
\text { thoracic surgery: } \\
\text { systematic review and } \\
\text { meta-analysis of } \\
\text { randomized trials }\end{array}$ & $\begin{array}{l}\text { Postoperative } \\
\text { pain- } \\
\text { thoracic } \\
\text { surgery }\end{array}$ & Control & 6 & TENS $=108$ & Control $=107$ & $\begin{array}{l}\text { Absolute } \\
\text { Difference } \\
\text { during/post } \\
\text { TENS }\end{array}$ & -13.3 & -18.9 & -7.7 & \\
\hline \multicolumn{12}{|c|}{ Mean Difference-unclear whether absolute difference or difference relative to baseline } \\
\hline $\begin{array}{l}\text { Abou-Setta } \\
\text { et al., } 2011[90]\end{array}$ & $\begin{array}{c}\text { Comparative Effectiveness } \\
\text { of Pain Management } \\
\text { Interventions for Hip } \\
\text { Fracture: A Systematic } \\
\text { Review }\end{array}$ & $\begin{array}{l}\text { Bone } \\
\text { fracture- } \\
\text { hip }\end{array}$ & $\begin{array}{l}\text { Standard of } \\
\text { care }\end{array}$ & 2 & Not reported & Not reported & Unclear & -2.79 & -4.95 & -0.64 & \\
\hline $\begin{array}{l}\text { Malone and } \\
\text { Strube 1988 } \\
\text { [91] }\end{array}$ & $\begin{array}{l}\text { Meta-analysis of } \\
\text { non-medical treatments for } \\
\text { chronic pain }\end{array}$ & $\begin{array}{l}\text { Chronic } \\
\text { pain- } \\
\text { various }\end{array}$ & $\begin{array}{l}\text { No } \\
\text { treatment }\end{array}$ & 2 & Not reported & Not reported & Unclear & 0.46 & $\begin{array}{l}\text { Not } \\
\text { reported }\end{array}$ & $\begin{array}{l}\text { Not } \\
\text { reported }\end{array}$ & $\begin{array}{l}\text { MD TENS vs. no treatment } \\
\text { control }=0.46(\mathrm{SD}=0.07)\end{array}$ \\
\hline
\end{tabular}

Key: IFT = interferential therapy; CI = 95\% Confidence Interval. 
Standardised Mean Difference during or post TENS relative to baseline

Brosseau et al., 2002 [62]

Jin et al. 2010 [66]

Arik et al. 2021 [70]

Johnson and Martinson 2007 [10]

Corbett et al. 2013 [68]

Stein et al. 2013 [65]

Wu et al. 2018 [14]

Philadelphia Panel 2001 [64]

Keller et al. 2007 [63]

Price and Pandyan 2000 [72]

Almeida et al. 2018 [67]* vs IFT

Standardised Mean Difference during or post TENS (absolute difference)

Zimpel et al. 2020 [73]

Dowswell et al. 2009 [22]

Zeng et al. 2015 [76]

Zhu et al. 2017 [75]

Li and Song 2021 [74]

Unclear whether absolute difference or difference relative to baseline

Chen et al. 2016 [77]

Rutjes et al. 2009 [78]

Sawant et al. 2015 [79]

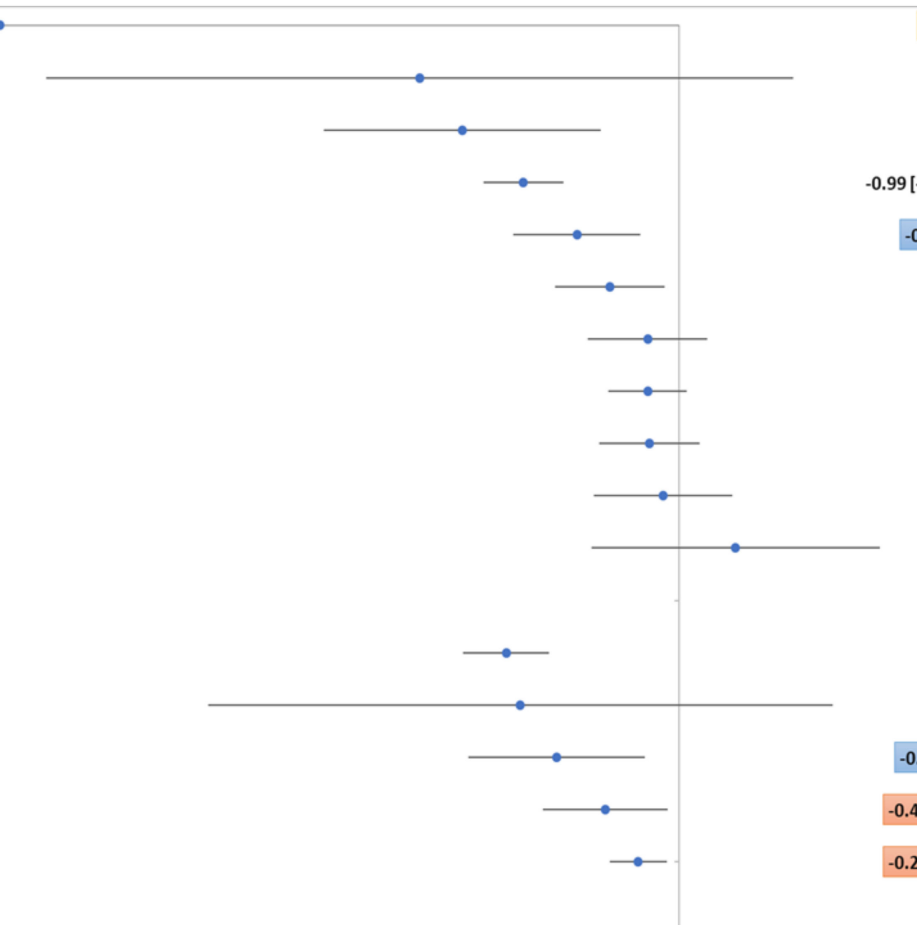

$-4.32[-10.36,-1.72], n=171$, Chronic low back pain $-1.65[-4.02,0.73], \mathrm{n}=42$, Diabetic neuropathy

$-1.38[-2.26,-0.5], \mathrm{n}=299$, Dysmenorrhoea

$9[-1.25,-0.74], \mathrm{n}=1692$, Chronie musculoskeletal pai

$0.65[-1.06,-0.25], \mathrm{n}=\mathrm{NR}$, Osteoarthritis - knee pain $-0.44[-0.79,-0.09], n=133$, Diabetic neuropathy

$-0.2[-0.58,0.18], \mathrm{n}=397$, Chronic low back pain $-0.2[-0.4,0.1], \mathrm{n}=\mathrm{NR}$, Chronic low back pain $-0.19[-0.51,0.3], \mathrm{n}=228$, Chronic low back pain

$-0.1[-0.54,0.34], \mathrm{n}=84$, Post-stroke - shoulder $0.36[-0.56,1.27], \mathrm{n}=492$, Acute $/$ chronic - various

$-1.1[-1.37,-0.82], n=238$, Postop. - caesarean

$-1.01[-3,0.97], \mathrm{n}=299$, Labour pain

$-0.78[-1.34,-0.22], n=329$, Osteoarthritis - knee pain $-0.47[-0.87,-0.08], n=102$, Postop. - knee arthroplasty $-0.26[-0.44,-0.08], \mathrm{n}=265$, Postop. - knee arthroplasty

$-0.79[-1.31,-0.27], \mathrm{n}=\mathrm{NR}$, Osteoarthritis - knee pain $-0.85[-1.36,-0.34], \mathrm{n}=465$, Osteoarthritis - knee pain $-0.35[-0.61,-0.09] \mathrm{n}=219$, Multiple sclerosis - central pain

$\begin{array}{lll}-8 & -6 & -4\end{array}$

\section{Standardised Mean Difference}

(a) Standardised Mean Difference

Figure 11. Cont. 
Mean Difference during or post TENS relative to baseline

Bjordal et al. 2007 [82]

Salazar et al., 2017 [81]

Mean Difference during or post TENS (absolute difference)

Simpson et al., 2014 [84]

Johnson et al., 2015 [83]

Gibson et al., 2017 [13]

Sbruzzi et al., 2012 [89] - Analysis 2

Sbruzzi et al.. 2012 [89]-Analysis 1

Zhou et al. $2020[88]$

Resende et al. 2018 [51]

Binny et al., 2019 [85]

Unclear whether absolute difference or difference relative to baseline

Abou-Setta et al., 2011 [90]* vs SoC

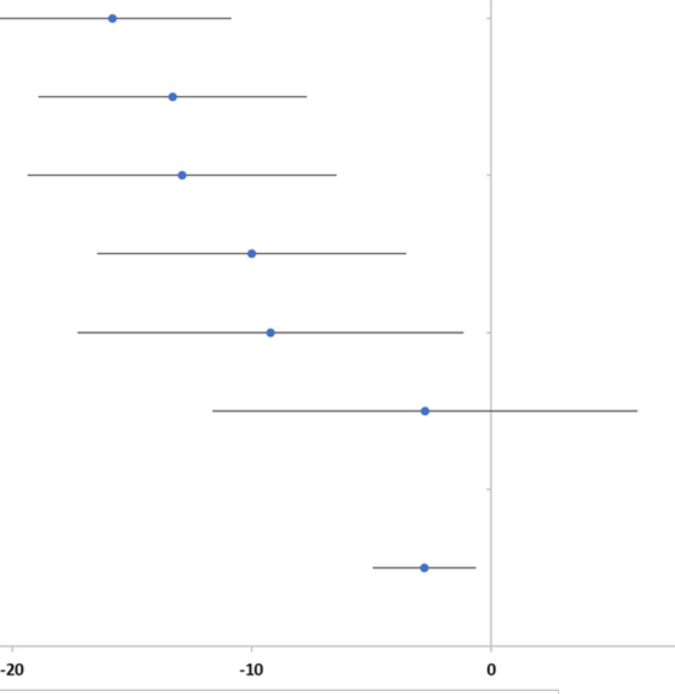

Mean Difference (100 units)
$-22.1[-26.3,-18.2], n=277$, Osteoarthritis - knee pain

$-1.42[-3.27,0.59], \mathrm{n}=120$, Fibromyalgia

$-32.7[-44.41,-20.97], n=261$, Acute pain - various

$-24.6[-31.79,-17.4], n=436$, Acute pain - various

$-15.8[-20.8,-10.9], n=207$, Neuropathic pain - various

$-13.3[-18.9,-7.7], n=215$, Postop. - thoracic

$-12.9[-19.4,-6.5], n=230$, Postop. - thoracic

$-10.0[-16.4,-3.5], n=383$, Postop. - pulmonary

$-9.2[-17.3,-1.2], \mathrm{n}=290$, Chronic back/neck pain

$-2.75[-11.63,6.13], n=129$, Acute low back pain

$-2.79[-4.95,-0.64], n=N R$, Bone fracture - hip

30

(b) Mean Difference

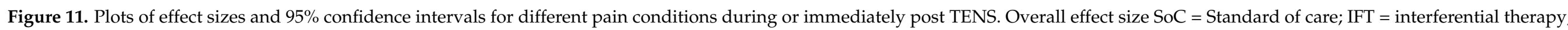

* indicates not versus placebo control. Pain conditions have been highlighted in colour (right hand column). 
Table 4. Summary of reviews that include evaluation of TENS for a mixture of painful conditions. The column 'Authors' Conclusion' contains statements taken from reports.

\begin{tabular}{|c|c|c|c|c|c|c|c|c|c|c|}
\hline Ref. & Title & Condition & $\begin{array}{l}\text { Acute/Chronic } \\
\text { Pain }\end{array}$ & $\begin{array}{l}\text { Review } \\
\text { Type }\end{array}$ & $\begin{array}{l}\text { Number } \\
\text { of } \\
\text { TENS } \\
\text { Studies }\end{array}$ & $\begin{array}{l}\text { Meta- } \\
\text { Analysis }\end{array}$ & Authors' Conclusion & $\begin{array}{c}\text { Authors' } \\
\text { Judgement }\end{array}$ & $\begin{array}{l}\text { Our } \\
\text { Judgement }\end{array}$ & Comment \\
\hline \multicolumn{11}{|c|}{ Mixtures of different types of Chronic Pain } \\
\hline Axon et al. [92] & $\begin{array}{c}\text { Use of multidomain } \\
\text { management strategies by } \\
\text { community dwelling } \\
\text { adults with chronic pain: } \\
\text { evidence from a systematic } \\
\text { review }\end{array}$ & $\begin{array}{c}\text { Chronic } \\
\text { pain-various }\end{array}$ & Chronic & SR & 6 & $\mathrm{~N}$ & $\begin{array}{l}\text { No statement of conclusion for } \\
\text { TENS }\end{array}$ & $?$ & $?$ & \\
\hline Baird et al. [93] & $\begin{array}{l}\text { Interventions for treating } \\
\text { persistent pain in } \\
\text { survivors of torture }\end{array}$ & $\begin{array}{c}\text { Chronic } \\
\text { pain-various }\end{array}$ & Chronic & $\mathrm{CR}$ & 1 & $\mathrm{~N}$ & $\begin{array}{l}\text { No statement of conclusion for } \\
\text { TENS }\end{array}$ & $?$ & $?$ & $\begin{array}{c}\text { Only } 1 \text { RCT-TENS as } \\
\text { part of combination } \\
\text { therapy }\end{array}$ \\
\hline Park et al. [95] & $\begin{array}{l}\text { Nonpharmacological } \\
\text { Approaches to the } \\
\text { Management of Chronic } \\
\text { Pain in } \\
\text { Community-Dwelling } \\
\text { Older Adults: A Review of } \\
\text { Empirical Evidence }\end{array}$ & $\begin{array}{c}\text { Chronic } \\
\text { pain-various }\end{array}$ & Chronic & SR & 3 & $\mathrm{~N}$ & $\begin{array}{l}\text { Although the findings of the } \\
\text { effectiveness of TENS are } \\
\text { inconsistent in the reviewed } \\
\text { studies, there was a trend } \\
\text { toward greater pain reduction } \\
\text { with active TENS than with } \\
\text { placebo or the combination of } \\
\text { TENS and acupuncture }\end{array}$ & $?$ & $?$ & \\
\hline$\underset{[96]}{\text { Nnoham et al. }}$ & TENS for chronic pain & $\begin{array}{c}\text { Chronic } \\
\text { pain-various }\end{array}$ & Chronic & $\mathrm{CR}$ & 25 & $\mathrm{~N}$ & $\begin{array}{l}\text { Despite the widespread use of } \\
\text { TENS machines, the analgesic } \\
\text { effectiveness of TENS still } \\
\text { remains uncertain }\end{array}$ & $?$ & $?$ & $\begin{array}{l}\text { Update of Carroll et al. } \\
\text { [97] by different team so } \\
\text { included }\end{array}$ \\
\hline
\end{tabular}


Table 4. Cont.

\begin{tabular}{|c|c|c|c|c|c|c|c|c|c|c|}
\hline Ref. & Title & Condition & $\begin{array}{l}\text { Acute/Chronic } \\
\text { Pain }\end{array}$ & $\begin{array}{l}\text { Review } \\
\text { Type }\end{array}$ & $\begin{array}{l}\text { Number } \\
\text { of } \\
\text { TENS } \\
\text { Studies }\end{array}$ & $\begin{array}{l}\text { Meta- } \\
\text { Analysis }\end{array}$ & Authors' Conclusion & $\begin{array}{c}\text { Authors' } \\
\text { Judgement }\end{array}$ & $\begin{array}{c}\text { Our } \\
\text { Judgement }\end{array}$ & Comment \\
\hline \multicolumn{11}{|c|}{ Mixtures of different types of Chronic Pain } \\
\hline Carroll et al. [97] & $\begin{array}{l}\text { Transcutaneous electrical } \\
\text { nerve stimulation (TENS) } \\
\text { for chronic pain }\end{array}$ & $\begin{array}{c}\text { Chronic } \\
\text { pain-various }\end{array}$ & Chronic & $\mathrm{CR}$ & 19 & $\mathrm{~N}$ & $\begin{array}{c}\text { There is insufficient evidence } \\
\text { to draw any conclusions about } \\
\text { the effectiveness of TENS for } \\
\text { the treatment of chronic pain in } \\
\text { adults }\end{array}$ & ? & $?$ & $\begin{array}{l}\text { Updated in } 2008 \\
\text { (Nnoaham and } \\
\text { Kumbang, 2008) } \\
\text { [19 RCTs from } \\
18 \text { reports] }\end{array}$ \\
\hline Reeve et al. [98] & $\begin{array}{l}\text { Transcutaneous electrical } \\
\text { nerve stimulation (TENS): } \\
\text { a technology assessment }\end{array}$ & $\begin{array}{c}\text { Chronic } \\
\text { pain—various }\end{array}$ & Chronic & SR & 10 & $\mathrm{~N}$ & $\begin{array}{l}\ldots \text { there is little evidence of } \\
\text { the effectiveness of TENS in } \\
\text { treating chronic pain }\end{array}$ & ? & $?$ & $\begin{array}{l}\text { One report containing } \\
3 \text { separate SRs }\end{array}$ \\
\hline $\begin{array}{l}\text { Malone et al. } \\
\text { [91] }\end{array}$ & $\begin{array}{l}\text { Meta-analysis of } \\
\text { non-medical treatments for } \\
\text { chronic pain }\end{array}$ & $\begin{array}{c}\text { Chronic } \\
\text { pain-various }\end{array}$ & Chronic & SR & 7 & $\mathrm{Y}$ & $\begin{array}{l}\text { Effect sizes for operant training } \\
\text { and TENS were no larger than } \\
\text { the estimated effect size for } \\
\text { control conditions }\end{array}$ & - & ? & \\
\hline \multicolumn{11}{|c|}{ Acute Pain (Various) 3 reviews } \\
\hline $\begin{array}{c}\text { Johnson et al. } \\
{[83]}\end{array}$ & $\begin{array}{l}\text { Transcutaneous electrical } \\
\text { nerve stimulation for acute } \\
\text { pain }\end{array}$ & $\begin{array}{c}\text { Acute } \\
\text { pain-various }\end{array}$ & Acute & $\mathrm{CR}$ & 26 & Y & $\begin{array}{l}\text { The analysis provides tentative } \\
\text { evidence that TENS reduces } \\
\text { pain intensity over and above } \\
\text { that seen with placebo (no } \\
\text { current) TENS when } \\
\text { administered as a stand-alone } \\
\text { treatment for acute pain in } \\
\text { adults }\end{array}$ & + & $?$ & $\begin{array}{c}\text { Comprehensive } \\
\text { review-only assessed } \\
\text { TENS as a stand-alone } \\
\text { treatment }\end{array}$ \\
\hline
\end{tabular}


Table 4. Cont.

\begin{tabular}{|c|c|c|c|c|c|c|c|c|c|c|}
\hline Ref. & Title & Condition & $\begin{array}{c}\text { Acute/Chronic } \\
\text { Pain }\end{array}$ & $\begin{array}{l}\text { Review } \\
\text { Type }\end{array}$ & $\begin{array}{l}\text { Number } \\
\text { of } \\
\text { TENS } \\
\text { Studies }\end{array}$ & $\begin{array}{l}\text { Meta- } \\
\text { Analysis }\end{array}$ & Authors' Conclusion & $\begin{array}{c}\text { Authors' } \\
\text { Judgement }\end{array}$ & $\begin{array}{c}\text { Our } \\
\text { Judgement }\end{array}$ & Comment \\
\hline \multicolumn{11}{|c|}{ Acute Pain (Various) 3 reviews } \\
\hline Simpson et al. & $\begin{array}{l}\text { Transcutaneous electrical } \\
\text { nerve stimulation for } \\
\text { relieving acute pain in the } \\
\text { prehospital setting }\end{array}$ & $\begin{array}{l}\text { Acute } \\
\text { pain-various in } \\
\text { prehospital } \\
\text { setting }\end{array}$ & Acute & SR & 4 & $\mathrm{Y}$ & $\begin{array}{l}\text { When administered by medics } \\
\text { in the prehospital setting to } \\
\text { patients with acute pain, TENS } \\
\text { appears to be an effective and } \\
\text { safe nonpharmacological } \\
\text { analgesic modality that should } \\
\text { be considered by emergency } \\
\text { medical services organizations } \\
\text { in which pharmacological pain } \\
\text { management is restricted or } \\
\text { unavailable }\end{array}$ & + & ? & \\
\hline Reeve et al. [98] & $\begin{array}{l}\text { Transcutaneous electrical } \\
\text { nerve stimulation (TENS): } \\
\text { a technology assessment }\end{array}$ & Acute-various & Acute & SR & 24 & $\mathrm{~N}$ & $\begin{array}{c}\text {.. published evidence is } \\
\text { equivocal in acute pain } \\
\text { treatment }\end{array}$ & ? & ? & $\begin{array}{l}\text { One report containing } \\
3 \text { separate SRs }\end{array}$ \\
\hline \multicolumn{11}{|c|}{ Mixed Chronic/Acute Pain (Various) 2 reviews } \\
\hline$\underset{[67]}{\text { Almeida et al. }}$ & $\begin{array}{l}\text { Transcutaneous electrical } \\
\text { nerve stimulation and } \\
\text { interferential current } \\
\text { demonstrate similar effects } \\
\text { in relieving acute and } \\
\text { chronic pain: a systematic } \\
\text { review with meta-analysis }\end{array}$ & $\begin{array}{l}\text { Various-acute } \\
\text { and chronic }\end{array}$ & Both & SR & 8 & $\mathrm{Y}$ & $\begin{array}{l}\text { Transcutaneous electrical nerve } \\
\text { stimulation and interferential } \\
\text { current have similar effects on } \\
\text { pain outcome }\end{array}$ & + & ? & $\begin{array}{l}\text { There was no } \\
\text { comparison with } \\
\text { control/placebo }\end{array}$ \\
\hline $\begin{array}{l}\text { Samuel et al. } \\
\text { [99] }\end{array}$ & $\begin{array}{l}\text { Application of Low } \\
\text { Frequency and Medium } \\
\text { Frequency Currents in the } \\
\text { Management of Acute and } \\
\text { Chronic Pain-A } \\
\text { Narrative Review }\end{array}$ & $\begin{array}{l}\text { Various-acute } \\
\text { and chronic }\end{array}$ & Both & MR & $9 \stackrel{3}{\mathrm{SRs}}$ & $\mathrm{N}$ & $\begin{array}{l}\text { We found through this review } \\
\text { that even though TENS and } \\
\text { IFT are used in management of } \\
\text { pain, there is limited amount of } \\
\text { high-quality research available }\end{array}$ & $?$ & ? & \\
\hline
\end{tabular}

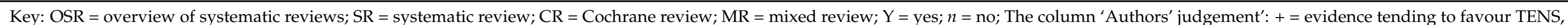

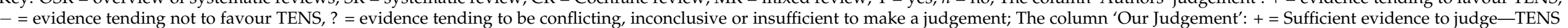
beneficial; - = Sufficient evidence to judge-TENS not beneficial; + / - = Sufficient evidence to judge-inconclusive; ? = Insufficient evidence to judge. 
We included 12 systematic reviews and one hybrid review. The earliest attempt to meta-analyse data on TENS was published by Malone and Strube in 1988 [91] in a report that described an evaluation of non-medical treatments for chronic pain. They claimed that effect sizes for TENS were no larger than the estimated effect size for control conditions although this conclusion was based on pooling of insufficient data from two studies. The first systematic reviews that focused solely on TENS for chronic pain were conducted in the mid to late 1990s, including the first Cochrane review of TENS for chronic pain [97], and they revealed a plethora of issues that compromised methodological quality of RCTs on TENS that remain unresolved to the present time. The Cochrane review was updated by Khadilkar et al., in 2008 [100] and more recently converted into an overview of Cochrane reviews by Gibson et al., in 2019 [6] as described previously.

When judged against our criteria, there were no systematic reviews with sufficient data to make a judgement. Estimates of SMD or MD for TENS versus a control in metaanalyses are likely to be imprecise and uncertain. In summary, we judge that evidence within reviews is inconclusive. Recent NICE guidelines for chronic pain do not recommend that TENS should be offered for chronic primary pain.

\section{Mixtures of Acute Pain Conditions}

We included three systematic reviews. There were no overviews of systematic reviews or hybrid reviews. The earliest attempt to systematically review TENS for review a mixture of types of acute pain was published by Reeve et al., in 1996 [98], included predominantly post-operative pain and labour pain and was inconclusive. The most recent Cochrane review by Johnson et al., in 2015 [83] included studies that mostly evaluated TENS on various painful procedures including cervical laser surgery, venepuncture, and sigmoidoscopy as well as pain associated with post-partum uterine contractions and rib fractures and found tentative evidence of benefit. Reviews on specific painful procedural pains are discussed in Section 3.18.

When judged against our criteria, there were no systematic reviews with sufficient data to make a judgement and estimates of SMD or MD for TENS versus a control in meta-analyses are likely to be imprecise and uncertain. In summary, we judged evidence within reviews to be inconclusive. The NICE have not published guidelines for the management of acute pain per se but have published guidelines for management of acute pain for specific conditions.

\subsection{Musculoskeletal Pain (40 Reviews)}

We included 40 reviews that evaluated TENS for non-specific musculoskeletal pain, and we categorised two of these as acute non-specific back pain, 21 as chronic non-specific spinal back and / or neck pain, eight as non-specific neck pain (but not back) and nine as various types of chronic musculoskeletal pain (Table 5). 
Table 5. Summary of reviews that include evaluation of TENS for musculoskeletal pain. The column 'Authors' Conclusion' contains statements taken from reports.

\begin{tabular}{|c|c|c|c|c|c|c|c|c|c|c|}
\hline Ref. & Title & Condition & $\begin{array}{l}\text { Acute/Chronic } \\
\text { Pain }\end{array}$ & $\begin{array}{l}\text { Review } \\
\text { Type }\end{array}$ & $\begin{array}{l}\text { Number } \\
\text { of TENS } \\
\text { Studies }\end{array}$ & MA & Authors' Conclusion & $\begin{array}{c}\text { Authors' } \\
\text { Judgement }\end{array}$ & $\begin{array}{c}\text { Our } \\
\text { Judgement }\end{array}$ & Comment \\
\hline \multicolumn{11}{|c|}{ Various chronic musculoskeletal pain(9 reviews) } \\
\hline $\begin{array}{c}\text { Ely et al. } \\
\text { [101] }\end{array}$ & $\begin{array}{l}\text { Transcutaneous electrical } \\
\text { acupoint stimulation for } \\
\text { people with chronic } \\
\text { musculoskeletal pain: an } \\
\text { exploratory review }\end{array}$ & $\begin{array}{l}\text { Musculoskeletal } \\
\text { pain_chronic }\end{array}$ & Chronic & SR & 20 & $\mathrm{~N}$ & $\begin{array}{c}\text { People with chronic } \\
\text { musculoskeletal pain may achieve } \\
\text { pain relief using transcutaneous } \\
\text { electric acupoint stimulation but } \\
\text { the existing evidence is limited, } \\
\text { and high-quality clinical evidence } \\
\text { is required to establish efficacy }\end{array}$ & $?$ & $?$ & $\begin{array}{l}\text { We suspect that this } \\
\text { is the full report of } \\
\text { Ely et al. [102] }\end{array}$ \\
\hline $\begin{array}{l}\text { Nunes et al. } \\
\text { [103] }\end{array}$ & $\begin{array}{l}\text { Effectiveness of physical and } \\
\text { rehabilitation techniques in } \\
\text { reducing pain in chronic } \\
\text { trapezius myalgia: A } \\
\text { systematic review and } \\
\text { meta-analysis }\end{array}$ & $\begin{array}{l}\text { Myalgia-chronic } \\
\text { trapezius }\end{array}$ & Chronic & SR & 1 & $\mathrm{~N}$ & $\begin{array}{l}\text { There was very poor evidence that } \\
\text { TENS therapy and manual therapy } \\
\text { are effective in treating chronic } \\
\text { trapezius myalgia }\end{array}$ & $?$ & $?$ & \\
\hline $\begin{array}{l}\text { Almeida } \\
\text { et al. [104] }\end{array}$ & $\begin{array}{l}\text { Conservative interventions for } \\
\text { treating exercise-related } \\
\text { musculotendinous, } \\
\text { ligamentous and osseous groin } \\
\text { pain }\end{array}$ & $\begin{array}{c}\text { Exercise-related } \\
\text { musculotendi- } \\
\text { nous, ligamentous } \\
\text { and osseous groin } \\
\text { pain }\end{array}$ & $\mathrm{UC}$ & $\mathrm{CR}$ & 2 & $\mathrm{~N}$ & $\begin{array}{l}\text { The available evidence from the } \\
\text { randomized trials is insufficient to } \\
\text { advise on any specific conservative } \\
\text { modality for treating exercise } \\
\text { related groin pain. }\end{array}$ & $?$ & $?$ & $\begin{array}{l}\text { The authors could } \\
\text { not isolate effect of } \\
\text { TENS because the } \\
\text { included studies } \\
\text { delivered TENS as } \\
\text { part of multimodal } \\
\text { physiotherapy } \\
\text { treatment }\end{array}$ \\
\hline $\begin{array}{l}\text { Bellini et al. } \\
\text { [105] }\end{array}$ & $\begin{array}{l}\text { Physical therapy applied to } \\
\text { pathologies of rehabilitative } \\
\text { interest }\end{array}$ & $\begin{array}{l}\text { Musculoskeletal } \\
\text { pain }\end{array}$ & Chronic & SR & 5 & $\mathrm{~N}$ & $\begin{array}{l}\text { TENS is recommended for the } \\
\text { treatment of tibio-femoral } \\
\text { osteoarthritis, its effectiveness is } \\
\text { questionable for carpal tunnel } \\
\text { syndrome and not recommended } \\
\text { for the treatment of chronic } \\
\text { low-back pain }\end{array}$ & + & $?$ & \\
\hline $\begin{array}{l}\text { Vernon et al. } \\
\text { [106] }\end{array}$ & $\begin{array}{l}\text { Chiropractic management of } \\
\text { myofascial trigger points and } \\
\text { myofascial pain syndrome: a } \\
\text { systematic review of the } \\
\text { literature }\end{array}$ & Myofascial pain & Both & SR & 6 & $\mathrm{~N}$ & $\begin{array}{l}\text { There is moderately strong } \\
\text { evidence that TENS may be } \\
\text { effective in providing immediate } \\
\text { relief at trigger point. The evidence } \\
\text { level is B. }\end{array}$ & + & $?$ & $\begin{array}{l}\text { Evaluated } \\
\text { commonly used } \\
\text { treatments }\end{array}$ \\
\hline $\begin{array}{l}\text { Johnson } \\
\text { et al. [10] }\end{array}$ & $\begin{array}{l}\text { Efficacy of electrical nerve } \\
\text { stimulation for chronic } \\
\text { musculoskeletal pain: A } \\
\text { meta-analysis of randomized } \\
\text { controlled trials }\end{array}$ & $\begin{array}{l}\text { Musculoskeletal } \\
\text { pain-chronic }\end{array}$ & Chronic & SR & 29 & $\mathrm{Y}$ & $\begin{array}{l}\text { These results indicate that electrical } \\
\text { nerve stimulation is an effective } \\
\text { treatment modality for chronic } \\
\text { musculoskeletal pain and that } \\
\text { previous, equivocal results may } \\
\text { have been due to underpowered } \\
\text { studies. }\end{array}$ & + & + & $\begin{array}{c}\text { There were } 32 \text { RCTS } \\
\text { of which } 29 \text { were on } \\
\text { TENS and the rest } \\
\text { on peripheral nerve } \\
\text { stimuation }\end{array}$ \\
\hline
\end{tabular}


Table 5. Cont.

\begin{tabular}{|c|c|c|c|c|c|c|c|c|c|c|}
\hline Ref. & Title & Condition & $\begin{array}{l}\text { Acute/Chronic } \\
\text { Pain }\end{array}$ & $\begin{array}{l}\text { Review } \\
\text { Type }\end{array}$ & $\begin{array}{l}\text { Number } \\
\text { of TENS } \\
\text { Studies }\end{array}$ & MA & Authors' Conclusion & $\begin{array}{c}\text { Authors' } \\
\text { Judgement }\end{array}$ & $\begin{array}{c}\text { Our } \\
\text { Judgement }\end{array}$ & Comment \\
\hline \multicolumn{11}{|c|}{ Various chronic musculoskeletal pain(9 reviews) } \\
\hline $\begin{array}{l}\text { Rickards } \\
\text { et al. [107] }\end{array}$ & Myofascial trigger point pain & Myofascial & UC & SR & 7 & $\mathrm{~N}$ & $\begin{array}{l}\text { TENS appears to have an } \\
\text { immediate effect in decreasing pain } \\
\text { intensity in myofascial trigger } \\
\text { point pain of the neck and upper } \\
\text { back. However, there are } \\
\text { insufficient data to provide the } \\
\text { evidence of effectiveness for TENS } \\
\text { beyond immediately after } \\
\text { treatment. }\end{array}$ & + & $?$ & \\
\hline $\begin{array}{l}\text { O'Connor } \\
\text { et al. [108] }\end{array}$ & $\begin{array}{l}\text { The effectiveness of } \\
\text { physiotherapeutic } \\
\text { interventions in the } \\
\text { management of delayed onset } \\
\text { muscle soreness: A systematic } \\
\text { review }\end{array}$ & $\begin{array}{l}\text { Muscle } \\
\text { soreness-post } \\
\text { exercise }\end{array}$ & Acute & SR & 3 & $\mathrm{~N}$ & $\begin{array}{l}\text { The evidence did not support the } \\
\text { use of static stretching, cryotherapy, } \\
\text { acupuncture, pulsed ultrasound, } \\
\text { TENS, interferential therapy, and } \\
\text { microcurrent electrical stimulation }\end{array}$ & $?$ & $?$ & $\begin{array}{l}\text { The authors stated } \\
\text { that the evidence } \\
\text { was conflicting }\end{array}$ \\
\hline $\begin{array}{l}\text { Philadelphia } \\
\text { Panel [109] }\end{array}$ & $\begin{array}{c}\text { Philadelphia Panel } \\
\text { Evidence-Based Clinical } \\
\text { Practice Guidelines on Selected } \\
\text { Rehabilitation Interventions for } \\
\text { Shoulder Pain } \\
\end{array}$ & $\begin{array}{l}\text { Shoulder pain- } \\
\text { non-specific }\end{array}$ & Both & SR & 1 & $\mathrm{~N}$ & $\begin{array}{c}\text {... a lack of evidence regarding } \\
\text { efficacy }\end{array}$ & ? & ? & \\
\hline \multicolumn{11}{|c|}{ Non-specific back pain 21 reviews } \\
\hline $\begin{array}{l}\text { Nascimento } \\
\text { et al. [110] }\end{array}$ & $\begin{array}{l}\text { Effectiveness of interventions } \\
\text { for non-specific low back pain } \\
\text { in older adults. A systematic } \\
\text { review and meta-analysis }\end{array}$ & $\begin{array}{c}\text { Back } \\
\text { pain—chronic low }\end{array}$ & Chronic & SR & 1 & $\mathrm{~N}$ & $\begin{array}{c}\text { No statement of conclusion for } \\
\text { TENS }\end{array}$ & ? & $?$ & $\begin{array}{l}\text { The authors } \\
\text { commented that a } \\
\text { previous study } \\
\text { showed a higher } \\
\text { effectiveness of } \\
\text { percutaneous } \\
\text { electrical nerve } \\
\text { stimulation (PENS) } \\
\text { to decrease pain } \\
\text { compared to TENS } \\
\text { at short-term } \\
\text { follow-up. }\end{array}$ \\
\hline $\begin{array}{l}\text { Resende } \\
\text { et al. [51] }\end{array}$ & $\begin{array}{c}\text { Meta-analysis of } \\
\text { transcutaneous electrical nerve } \\
\text { stimulation for relief of spinal } \\
\text { pain }\end{array}$ & $\begin{array}{l}\text { Back and/or neck } \\
\text { pain—chronic }\end{array}$ & Chronic & SR & 9 & $\mathrm{Y}$ & $\begin{array}{l}\text {... inconclusive evidence of TENS } \\
\text { benefits in low back pain patients } \\
\text { because the quality of the studies } \\
\text { was low, and adequate parameters } \\
\text { and timing of assessment were not } \\
\text { uniformly used or reported. }\end{array}$ & $?$ & ? & $\begin{array}{l}\text { Nine RCTs with } \\
\text { seven data sets } \\
\text { included for } \\
\text { meta-analysis } \\
\text { (655 participants) }\end{array}$ \\
\hline
\end{tabular}


Table 5. Cont.

\begin{tabular}{|c|c|c|c|c|c|c|c|c|c|c|}
\hline Ref. & Title & Condition & $\begin{array}{l}\text { Acute/Chronic } \\
\text { Pain }\end{array}$ & $\begin{array}{l}\text { Review } \\
\text { Type }\end{array}$ & $\begin{array}{l}\text { Number } \\
\text { of TENS } \\
\text { Studies }\end{array}$ & MA & Authors' Conclusion & $\begin{array}{c}\text { Authors' } \\
\text { Judgement }\end{array}$ & $\begin{array}{c}\text { Our } \\
\text { Judgement }\end{array}$ & Comment \\
\hline \multicolumn{11}{|c|}{ Non-specific back pain 21 reviews } \\
\hline $\begin{array}{l}\text { Wu et al. } \\
\text { [14] }\end{array}$ & $\begin{array}{c}\text { Literature Review and } \\
\text { Meta-Analysis of } \\
\text { Transcutaneous Electrical } \\
\text { Nerve Stimulation in Treating } \\
\text { Chronic Back Pain }\end{array}$ & $\begin{array}{c}\text { Back } \\
\text { pain-Chronic }\end{array}$ & Chronic & SR & 12 & Y & $\begin{array}{l}\text { These results suggest that TENS } \\
\text { does not improve symptoms of } \\
\text { lower back pain but may offer } \\
\text { short-term improvement of } \\
\text { functional disability. }\end{array}$ & - & $?$ & \\
\hline $\begin{array}{l}\text { Bredow } \\
\text { et al. [111] }\end{array}$ & $\begin{array}{l}\text { Non-specific chronic low back } \\
\text { pain (NSCLBP): Which } \\
\text { conservative therapy shows an } \\
\text { evident effectiveness-A } \\
\text { review of the current literature }\end{array}$ & $\begin{array}{c}\text { Back } \\
\text { pain—chronic } \\
\text { non-specific (low) }\end{array}$ & Chronic & MR & $1 \mathrm{SR}$ & $\mathrm{N}$ & $\begin{array}{l}\text { In a Cochrane analysis by } \\
\text { Khadilkar et al. [100] regarding the } \\
\text { use of TENS there is no evidence } \\
\text { regarding the treatment of } \\
\text { Non-specific chronic low back pain }\end{array}$ & $?$ & $?$ & $\begin{array}{l}\text { Article in German } \\
\text { No RCTS were } \\
\text { included }\end{array}$ \\
\hline $\begin{array}{l}\text { Jauregui } \\
\text { et al. [52] }\end{array}$ & $\begin{array}{c}\text { A Meta-Analysis of } \\
\text { Transcutaneous Electrical } \\
\text { Nerve Stimulation for Chronic } \\
\text { Low Back Pain }\end{array}$ & Back—chronic low & Chronic & SR & 12 & Y & $\begin{array}{l}\text { Treatment of chronic low back pain } \\
\text { with TENS demonstrated } \\
\text { significant pain reduction. The } \\
\text { application of TENS may lead to } \\
\text { less pain medication usage and } \\
\text { should be incorporated into the } \\
\text { treatment armamentarium for } \\
\text { chronic low back pain }\end{array}$ & + & $?$ & \\
\hline $\begin{array}{l}\text { van } \\
\text { Middelkoop } \\
\text { et al. [53] }\end{array}$ & $\begin{array}{l}\text { A systematic review on the } \\
\text { effectiveness of physical and } \\
\text { rehabilitation interventions for } \\
\text { chronic non-specific low back } \\
\text { pain }\end{array}$ & $\begin{array}{c}\text { Back } \\
\text { pain—chronic low }\end{array}$ & Chronic & SR & 6 & $\mathrm{Y}$ & $\begin{array}{l}\text { The data provided low quality } \\
\text { evidence (serious limitations, } \\
\text { heterogeneity) that there is no } \\
\text { statistically significant difference } \\
\text { on post-treatment pain intensity } \\
\text { and disability between TENS and } \\
\text { sham-TENS }\end{array}$ & - & $?$ & \\
\hline Chou [113] & Low back pain (chronic) & $\begin{array}{c}\text { Back } \\
\text { pain—chronic low }\end{array}$ & Chronic & SR & 3 & $\mathrm{~N}$ & $\begin{array}{l}\text { Compared with placebo: We don't } \\
\text { know whether TENS is more } \\
\text { effective at reducing pain in people } \\
\text { with chronic low back pain (very } \\
\text { low-quality evidence). Compared } \\
\text { with sham TENS plus massage: } \\
\text { TENS plus massage may be no } \\
\text { more effective at reducing pain in } \\
\text { people with chronic low back pain } \\
\text { (low-quality evidence). }\end{array}$ & $?$ & $?$ & $\begin{array}{l}\text { Update of Hall and } \\
\text { McIntosh [114] }\end{array}$ \\
\hline
\end{tabular}


Table 5. Cont.

\begin{tabular}{|c|c|c|c|c|c|c|c|c|c|c|}
\hline Ref. & Title & Condition & $\begin{array}{l}\text { Acute/Chronic } \\
\text { Pain }\end{array}$ & $\begin{array}{l}\text { Review } \\
\text { Type }\end{array}$ & $\begin{array}{l}\text { Number } \\
\text { of TENS } \\
\text { Studies }\end{array}$ & MA & Authors' Conclusion & $\begin{array}{c}\text { Authors' } \\
\text { Judgement }\end{array}$ & $\begin{array}{l}\text { Our } \\
\text { Judgement }\end{array}$ & Comment \\
\hline \multicolumn{11}{|c|}{ Non-specific back pain 21 reviews } \\
\hline $\begin{array}{l}\text { Dubinsky } \\
\text { et al. [115] }\end{array}$ & $\begin{array}{l}\text { Assessment: Efficacy of } \\
\text { transcutaneous electric nerve } \\
\text { stimulation in the treatment of } \\
\text { pain in neurologic disorders } \\
\text { (an evidence-based review) }\end{array}$ & Back—chronic low & Chronic & SR & 4 & $\mathrm{~N}$ & $\begin{array}{l}\text { TENS is not recommended for the } \\
\text { treatment of chronic low back pain } \\
\text { (Level A) }\end{array}$ & - & $?$ & $\begin{array}{l}\text { Conducted two } \\
\text { analyses in same } \\
\text { report-this is data } \\
\text { for back pain only. } \\
\text { See rebuttal by } \\
\text { Johnson and Walsh } \\
\text { [116] }\end{array}$ \\
\hline $\begin{array}{l}\text { Gutiérrez } \\
\text { et al. [118] }\end{array}$ & $\begin{array}{l}\text { Evidence of the analgesic effect } \\
\text { of physiotherapy in the low } \\
\text { backpain syndrome }\end{array}$ & Low Back Pain & Both & SR & 4 & $\mathrm{~N}$ & $\begin{array}{l}\text {... controversial evidence } \\
\text { regarding the use of laser and } \\
\text { TENS in sub-acute and chronic low } \\
\text { back pain }\end{array}$ & $?$ & $?$ & \\
\hline $\begin{array}{l}\text { Machado } \\
\text { et al. [86] }\end{array}$ & $\begin{array}{l}\text { Analgesic effects of treatments } \\
\text { for non-specific low back pain: } \\
\text { a meta-analysis of } \\
\text { placebo-controlled randomized } \\
\text { trials }\end{array}$ & $\begin{array}{l}\text { Back } \\
\text { pain—chronic low }\end{array}$ & Both & SR & 4 & Y & $\begin{array}{c}\text { No statement of conclusion for } \\
\text { TENS }\end{array}$ & $?$ & $?$ & $\begin{array}{l}\text { No numerical data } \\
\text { of effect size but the } \\
\text { forest plot revealed } \\
\text { the upper } \\
\text { confidence interval } \\
\text { was in favour of } \\
\text { TENS and did not } \\
\text { bisect the line of no } \\
\text { difference }\end{array}$ \\
\hline $\begin{array}{l}\text { Khadilkar } \\
\text { et al. [100] }\end{array}$ & $\begin{array}{l}\text { Transcutaneous electrical nerve } \\
\text { stimulation (TENS) versus } \\
\text { placebo for chronic low-back } \\
\text { pain (Review) }\end{array}$ & Back—chronic low & Chronic & $\mathrm{CR}$ & 5 & $\mathrm{~N}$ & $\begin{array}{l}\text {... evidence from the small } \\
\text { number of placebo-controlled trials } \\
\text { does not support the use of TENS } \\
\text { in the routine management of } \\
\text { chronic low back pain }\end{array}$ & - & $?$ & $\begin{array}{c}\text { Updates of } \\
\text { Khadilkar et al. } \\
\text { [119] and Milne et al. } \\
\text { [120] }\end{array}$ \\
\hline $\begin{array}{l}\text { Poitras et al. } \\
\quad[87]\end{array}$ & $\begin{array}{c}\text { Evidence-informed } \\
\text { management of chronic low } \\
\text { back pain with transcutaneous } \\
\text { electrical nerve stimulation, } \\
\text { interferential current, electrical } \\
\text { muscle stimulation, } \\
\text { ultrasound, and } \\
\text { thermotherapy }\end{array}$ & $\begin{array}{c}\text { Back } \\
\text { pain—chronic low }\end{array}$ & Chronic & SR & 4 & Y & $\begin{array}{l}\text { Globally, high and low-frequency } \\
\text { TENS appears to have an } \\
\text { immediate impact on pain } \\
\text { intensity, with results favoring } \\
\text { high-frequency TENS }\end{array}$ & + & $?$ & $\begin{array}{l}\text { The North American } \\
\text { Spine Society } \\
\text { sponsored this } \\
\text { special focus issue. }\end{array}$ \\
\hline
\end{tabular}


Table 5. Cont.

\begin{tabular}{|c|c|c|c|c|c|c|c|c|c|c|}
\hline Ref. & Title & Condition & $\begin{array}{l}\text { Acute/Chronic } \\
\text { Pain }\end{array}$ & $\begin{array}{l}\text { Review } \\
\text { Type }\end{array}$ & $\begin{array}{l}\text { Number } \\
\text { of TENS } \\
\text { Studies }\end{array}$ & MA & Authors' Conclusion & $\begin{array}{l}\text { Authors' } \\
\text { Judgement }\end{array}$ & $\begin{array}{c}\text { Our } \\
\text { Judgement }\end{array}$ & Comment \\
\hline \multicolumn{11}{|c|}{ Non-specific back pain 21 reviews } \\
\hline Chou [61] & $\begin{array}{l}\text { Nonpharmacologic Therapies } \\
\text { for Acute and Chronic Low } \\
\text { Back Pain: A Review of the } \\
\text { Evidence for an American Pain } \\
\text { Society/American College of } \\
\text { Physicians Clinical Practice } \\
\text { Guideline }\end{array}$ & $\begin{array}{l}\text { Back pain—acute } \\
\text { and chronic }\end{array}$ & Both & MR & 6 $\stackrel{4}{\mathrm{SRs}}$ & $\mathrm{N}$ & $\begin{array}{l}\text { Other non-invasive therapies (back } \\
\text { schools, interferential therapy, } \\
\text { low-level laser therapy, lumbar } \\
\text { supports, TENS, traction, and } \\
\text { ultrasonography) have not been } \\
\text { shown to be effective for either } \\
\text { chronic or subacute or acute low } \\
\text { back pain } \\
\text { back }\end{array}$ & - & $?$ & \\
\hline $\begin{array}{l}\text { Keller et al. } \\
\quad[63]\end{array}$ & $\begin{array}{l}\text { Effect sizes of non-surgical } \\
\text { treatments of non-specific } \\
\text { low-back pain }\end{array}$ & $\begin{array}{c}\text { Back } \\
\text { pain—chronic low }\end{array}$ & Chronic & SR & 2 & Y & $\begin{array}{l}\text { TENS and manipulation had small } \\
\text { effect sizes }\end{array}$ & $?$ & $?$ & \\
\hline $\begin{array}{l}\text { Brosseau } \\
\text { et al. [62] }\end{array}$ & $\begin{array}{l}\text { Efficacy of the transcutaneous } \\
\text { electrical nerve stimulation for } \\
\text { the treatment of chronic low } \\
\text { back pain-A meta-analysis. }\end{array}$ & $\begin{aligned} & \text { Back } \\
& \text { pain—chronic low }\end{aligned}$ & Chronic & SR & 5 & $\mathrm{Y}$ & $\begin{array}{l}\text { The results of the meta-analysis } \\
\text { present no evidence to support the } \\
\text { use or non-use of TENS alone in } \\
\text { the treatment of chronic low back } \\
\text { pain }\end{array}$ & $?$ & $?$ & \\
\hline $\begin{array}{l}\text { Pengel et al. } \\
\text { [121] }\end{array}$ & $\begin{array}{l}\text { Systematic review of } \\
\text { conservative interventions for } \\
\text { subacute low back pain }\end{array}$ & $\begin{array}{l}\text { Back } \\
\text { pain—subacute } \\
\text { low }\end{array}$ & Both & SR & 3 & $\mathrm{~N}$ & $\begin{array}{l}\ldots \text { there is evidence that .... other } \\
\text { treatments (e.g., manipulation, } \\
\text { exercise, TENS) may be effective }\end{array}$ & + & $?$ & \\
\hline $\begin{array}{l}\text { Philadelphia } \\
\text { Panel [64] }\end{array}$ & $\begin{array}{c}\text { Philadelphia Panel } \\
\text { Evidence-Based Clinical } \\
\text { Practice Guidelines on Selected } \\
\text { Rehabilitation Interventions for } \\
\text { Low Back Pain }\end{array}$ & $\begin{array}{l}\text { Back pain-low, } \\
\text { non-specific }\end{array}$ & Both & SR & 5 & $\mathrm{Y}$ & $\begin{array}{c}\ldots \text { a lack of evidence regarding } \\
\text { efficacy of TENS for Acute LBP }(<4 \\
\text { Weeks), Level I (RCT), Grade C for } \\
\text { Pain or Function (No Benefit } \\
\text { Demonstrated) }\end{array}$ & $?$ & $?$ & Detailed analysis \\
\hline $\begin{array}{c}\text { Flowerdew } \\
\text { and Gadsby } \\
\text { [122] }\end{array}$ & $\begin{array}{l}\text { A review of the treatment of } \\
\text { chronic low back pain with } \\
\text { acupuncture-like } \\
\text { transcutaneous electrical nerve } \\
\text { stimulation and } \\
\text { transcutaneous electrical nerve } \\
\text { stimulation }\end{array}$ & $\begin{array}{l}\text { Back pain-chronic } \\
\text { low }\end{array}$ & Chronic & SR & 6 & $\mathrm{Y}$ & $\begin{array}{l}\text { There is limited statistical evidence } \\
\text { that ALTENS and TENS reduce } \\
\text { pain and improve function in } \\
\text { patients with chronic low back } \\
\text { pain, at least in the short term }\end{array}$ & + & $?$ & \\
\hline $\begin{array}{l}\text { Gadsby et al. } \\
\text { [123] }\end{array}$ & Low back pain & Back pain-low & Chronic & SR & 6 & $\mathrm{Y}$ & $\begin{array}{c}\text {... clear evidence that } \\
\text { conventional TENS and } \\
\text { acupuncture-like TENS reduce } \\
\text { pain and increase range of motion } \\
\text { of patients with chronic low back } \\
\text { pain }\end{array}$ & + & $?$ & \\
\hline
\end{tabular}


Table 5. Cont.

\begin{tabular}{|c|c|c|c|c|c|c|c|c|c|c|}
\hline Ref. & Title & Condition & $\begin{array}{l}\text { Acute/Chronic } \\
\text { Pain }\end{array}$ & $\begin{array}{l}\text { Review } \\
\text { Type }\end{array}$ & $\begin{array}{l}\text { Number } \\
\text { of TENS } \\
\text { Studies }\end{array}$ & MA & Authors' Conclusion & $\begin{array}{l}\text { Authors' } \\
\text { Judgement }\end{array}$ & $\begin{array}{c}\text { Our } \\
\text { Judgement }\end{array}$ & Comment \\
\hline \multicolumn{11}{|c|}{ Low Back Pain (Acute) 2 reviews } \\
\hline $\begin{array}{l}\text { Binny et al. } \\
{[85]}\end{array}$ & $\begin{array}{l}\text { Transcutaneous electric nerve } \\
\text { stimulation (TENS) for acute } \\
\text { low back pain: systematic } \\
\text { review }\end{array}$ & $\begin{array}{l}\text { Back pain, low, } \\
\text { acute }\end{array}$ & Acute & SR & 3 & Y & $\begin{array}{l}\ldots \text { is insufficient [evidence] to } \\
\text { support or dismiss the use of TENS } \\
\text { for acute low back pain }\end{array}$ & $?$ & $?$ & \\
\hline $\begin{array}{l}\text { McIntosh } \\
\text { and Hall } \\
\text { [124] }\end{array}$ & Low back pain (acute) & Back pain—low & Acute & $\mathrm{SR}$ & 0 & $\mathrm{~N}$ & $\begin{array}{c}\text { No statement of conclusion for } \\
\text { TENS }\end{array}$ & $?$ & $?$ & \\
\hline \multicolumn{11}{|c|}{ Non-specific neck pain 8 reviews } \\
\hline $\begin{array}{l}\text { Martimbianco } \\
\text { et al. [125] }\end{array}$ & $\begin{array}{l}\text { Transcutaneous electrical nerve } \\
\text { stimulation (TENS) for chronic } \\
\text { neck pain }\end{array}$ & $\begin{array}{c}\text { Neck } \\
\text { pain—chronic }\end{array}$ & Chronic & SR & 7 & $\mathrm{~N}$ & $\begin{array}{l}\text {... there was very low-certainty } \\
\text { evidence from two trials about the } \\
\text { effects of conventional TENS when } \\
\text { compared to sham TENS at } \\
\text { short-term }\end{array}$ & $?$ & $?$ & $\begin{array}{l}\text { This is described as } \\
\text { a 'split' from } \\
\text { Kroeling } 2013^{\prime} \text {-we } \\
\text { include because } \\
\text { different team and } \\
\text { over } 5 \text { years elapsed } \\
\text { since original }\end{array}$ \\
\hline $\begin{array}{l}\text { (Kroeling } \\
\text { et al., 2013) }\end{array}$ & $\begin{array}{l}\text { Electrotherapy for neck pain } \\
\text { (Review) }\end{array}$ & Neck Pain & UC & $\mathrm{CR}$ & 10 & $\mathrm{~N}$ & $\begin{array}{c}\text { TENS ... might be more effective } \\
\text { than placebo (very low quality } \\
\text { evidence) }\end{array}$ & + & $?$ & \\
\hline $\begin{array}{c}\text { Jensen et al. } \\
\text { [56] }\end{array}$ & Neck pain & $\begin{array}{l}\text { Neck pain-non- } \\
\text { specific }\end{array}$ & UC & OSR & 0 & $\mathrm{~N}$ & $\begin{array}{l}\text { symptom relief this condition can } \\
\text { be treated with TENS }\end{array}$ & + & $?$ & \\
\hline $\begin{array}{l}\text { Vernon et al. } \\
\text { [127] }\end{array}$ & $\begin{array}{l}\text { A systematic review of } \\
\text { conservative treatment for } \\
\text { acute neck pain not due to } \\
\text { whiplash }\end{array}$ & $\begin{array}{l}\text { Neck pain-not } \\
\text { whiplash }\end{array}$ & Acute & SR & 1 & $\mathrm{~N}$ & $\begin{array}{l}\text { One trial } 47 \text { provides some } \\
\text { evidence that TENS treatment is } \\
\text { beneficial over a } 3 \text {-week interval }\end{array}$ & $?$ & $?$ & \\
\hline $\begin{array}{l}\text { Philadelphia } \\
\text { Panel [128] }\end{array}$ & $\begin{array}{c}\text { Philadelphia Panel } \\
\text { Evidence-Based Clinical } \\
\text { Practice Guidelines on Selected } \\
\text { Rehabilitation Interventions for } \\
\text { Neck Pain }\end{array}$ & $\begin{array}{l}\text { Neck pain-non- } \\
\text { specific }\end{array}$ & Both & SR & 1 & $\mathrm{~N}$ & $\begin{array}{c}\ldots \text {.. a lack of evidence regarding } \\
\text { efficacy ... TENS for acute neck } \\
\text { pain }\end{array}$ & $?$ & $?$ & \\
\hline
\end{tabular}


Table 5. Cont.

\begin{tabular}{|c|c|c|c|c|c|c|c|c|c|c|}
\hline Ref. & Title & Condition & $\begin{array}{l}\text { Acute/Chronic } \\
\text { Pain }\end{array}$ & $\begin{array}{l}\text { Review } \\
\text { Type }\end{array}$ & $\begin{array}{c}\text { Number } \\
\text { of TENS } \\
\text { Studies }\end{array}$ & MA & Authors' Conclusion & $\begin{array}{c}\text { Authors' } \\
\text { Judgement }\end{array}$ & $\begin{array}{l}\text { Our } \\
\text { Judgement }\end{array}$ & Comment \\
\hline \multicolumn{11}{|c|}{ Non-specific neck pain 8 reviews } \\
\hline $\begin{array}{l}\text { Kjellman } \\
\text { et al. [129] }\end{array}$ & $\begin{array}{l}\text { A critical analysis of } \\
\text { randomised clinical trials on } \\
\text { neck pain and treatment } \\
\text { efficacy. A review of the } \\
\text { literature }\end{array}$ & Neck pain & Both & SR & 3 & $\mathrm{~N}$ & $\begin{array}{l}\text { [No statement of conclusion for } \\
\text { TENS] }\end{array}$ & $\mathrm{U}$ & $?$ & $\begin{array}{l}\text { No conclusion on } \\
\text { TENS }\end{array}$ \\
\hline $\begin{array}{l}\text { Aker et al. } \\
\text { [130] }\end{array}$ & $\begin{array}{c}\text { Conservative management of } \\
\text { mechanical neck pain: } \\
\text { systematic overview and } \\
\text { meta-analysis }\end{array}$ & $\begin{array}{l}\text { Mechanical neck } \\
\text { pain }\end{array}$ & Both & SR & 2 & No & $\begin{array}{l}\text {... no treatments [including } \\
\text { TENS] have been studied in } \\
\text { enough detail to assess either } \\
\text { efficacy or effectiveness }\end{array}$ & $?$ & $?$ & $\begin{array}{l}\text { Article is a summary } \\
\text { of Gross et al. [131] }\end{array}$ \\
\hline
\end{tabular}

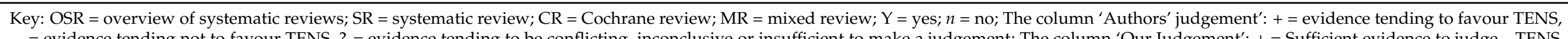

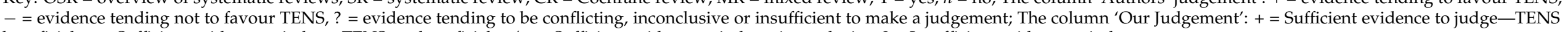
beneficial; $-=$ Sufficient evidence to judge - TENS not beneficial; $+/-=$ Sufficient evidence to judge - inconclusive; $?=$ Insufficient evidence to judge 
There was one overview of systematic reviews that did not include any data for TENS, although concluded that TENS could provide symptom relief of non-specific neck pain [56]; one mixed review that concluded that TENS was not shown to be effective for either chronic or subacute or acute low back pain based on four RCTs [61]; and one mixed review that summarised the Cochrane review by Khadilkar et al. [100] and concluded that there was no evidence to support efficacy of TENS for the treatment of non-specific chronic low back pain [111]. The systematic review by Johnson and Martinson in 2007 [10], evaluated TENS for a mixture of types of chronic non-specific musculoskeletal pain and is the largest meta-analysis of pooled data for TENS published to date. They pooled data from TENS and invasive peripheral nerve stimulation from a variety of different musculoskeletal conditions (29 RCTs, 32 comparisons) and found a significant reduction in pain during TENS compared with control [85]. The authors concluded that electrical nerve stimulation was effective treatment modality for chronic musculoskeletal pain. We judged there to be sufficient data to support efficacy for TENS against our criteria.

\section{Non-Specific Back Pain (21 Reviews on Chronic, Two Reviews on Acute)}

We included 21 systematic reviews of TENS for non-specific back pain and 2 hybrid reviews (Table 5). Good quality systematic reviews and meta analyses included Jauregui et al., published in 2016 [52], Wu et al., published in 2018 [14] and Resende et al., published in 2018 [51]. Jauregui et al. [52] suggested that their meta-analysis provided evidence that TENS reduced pain and medication; Wu et al. [14] that TENS improved functional disability but not lower back pain; and Resende et al. [51] that evidence was inconclusive based on large heterogeneity between studies. Their meta-analysis of 290 participants found that pain intensity was lower during TENS or interferential current therapy compared with placebo/control with an overall standardised mean difference of -0.92 (95\% CI -1.73 , $-0.12 ; p<0.02)$. The most recent Cochrane review by Khadilkar et al. [100], published in 2008, included five studies and concluded that evidence does not support the use of TENS in the routine management of chronic low back pain, although the review has been withdrawn and updated by the overview of Cochrane reviews for chronic pain by Gibson et al. [6]. When judged against our criteria, there were no systematic reviews with sufficient data to make a judgement. Also of note, was a comparison of the efficacy of 34 treatments for non-specific chronic low back pain published by Machado et al., in 2009 [86] which estimated that TENS reduced pain intensity between 10 and 20 percent of baseline and the magnitude of this effect was comparable with other treatments including muscle relaxants and non-steroidal anti-inflammatory drugs (NSAIDs).

In summary, the evidence suggests that there are insufficient high-quality RCTs to judge the efficacy of TENS for chronic non-specific back pain. The NICE guidelines for chronic non-specific back pain recommend that TENS should not be offered.

\section{Non-Specific Neck Pain (Eight Reviews)}

There was one overview of systematic reviews on a variety of treatments for nonspecific neck pain published in 2007 by Jensen and Harms-Ringdahl [56] and it did not find any previous systematics reviews that focused solely on TENS (Table 5). The most robust systematic review was published in 2019 by Martimbianco et al. [125] and was an update of an earlier Cochrane review by Kroeling et al. [132]. Martimbianco et al. [125] included seven studies but did not undertake a meta-analysis and concluded that there was very low-certainty evidence from two trials about the effects of conventional TENS when compared to sham TENS at short-term.

When judged against our criteria, there were no systematic reviews with sufficient data to make a judgement. In summary, the evidence suggests that there are insufficient high-quality RCTs to judge the efficacy of TENS for non-specific neck pain. 


\subsection{Osteoarthritis (13 Reviews)}

There were 11 systematic reviews and two overviews of systematic reviews that included evaluations of TENS for pain associated with osteoarthritis (Table 6). An overview of systematic reviews of physical therapy interventions for patients with osteoarthritis of the knee published in 2008 by Jamtvedt et al. [54] concluded that there is moderatequality evidence that TENS reduced pain based on the findings of one Cochrane review on TENS by Osiri et al. [133] published in 2000. The development of Osteoarthritis Research Society International (OARSI) recommendations included a systematic review evidence of treatments to manage osteoarthritis of the hip and knee by Zhang et al. [55] but did not include any systematic reviews or studies on TENS. Nevertheless, Zhang et al. [55] concluded that TENS can help with short-term pain control in some patients.

There were nine systematic reviews included in our appraisal. The most recent Cochrane review published in 2009 by Rutjes et al. [78] included 12 studies on TENS, including interferential current therapy, and "could not confirm that transcutaneous electrostimulation is effective for pain relief" (Abstract). In 2016, Chen et al. [77] published a review of 23 studies on TENS for knee osteoarthritis and concluded that TENS might relieve pain due to knee osteoarthritis based on a meta-analysis that did not report the size of the pooled data sample. In 2017, Ferronato et al. [134] published a systematic review of physical modalities on functional performance in knee osteoarthritis and concluded that " ... TENS seems to be as or more effective than other analgesic therapies".

When judged against our criteria, there were no systematic reviews with sufficient data to judge the efficacy of TENS. The NICE guidelines recommend that TENS should be offered for as an adjunct to core treatment to manage pain associated with osteoarthritis [135].

\subsection{Post-Operative Pain (13 Reviews)}

There were 13 systematic reviews but no overviews or hybrid reviews evaluating TENS for post-operative pain (Table 7). One of the first systematic reviews of TENS for post-operative pain was published by Carroll et al. [5] in 1996 and remains a seminal piece of work. Carroll et al. [5] tallied study outcome and found no difference in pain intensity between TENS and sham TENS in 14 of 17 RCTs. In contrast, 17 of 19 non-randomised studies reported lower pain intensity for TENS compared with sham TENS. Carroll et al., concluded that TENS did not alleviate post-operative pain and that non-randomized studies overestimated treatment effects.

In 2003, Bjordal et al. [11] argued that measurements of pain intensity may be compromised when participants are concurrently consuming analgesic medication. Bjordal et al. [11] conducted a meta-analysis of 21 RCTs that found a mean reduction in analgesic consumption after TENS to be $26.5 \%$ (range $6 \%$ to $51 \%$ ) when compared with placebo. Importantly, TENS technique moderated the effect with optimal reduction in analgesic consumption occurring in the presence of strong, sub noxious TENS sensation at the site of pain. When judged against our criteria, this review had sufficient data to support benefit of TENS for reducing opioid consumption. 


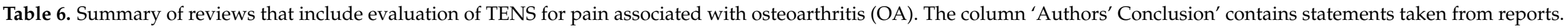

\begin{tabular}{|c|c|c|c|c|c|c|c|c|c|c|}
\hline Ref. & Title & Condition & $\begin{array}{l}\text { Acute/Chronic } \\
\text { Pain }\end{array}$ & $\begin{array}{l}\text { Review } \\
\text { Type }\end{array}$ & $\begin{array}{l}\text { Number } \\
\text { of TENS } \\
\text { Studies }\end{array}$ & $\begin{array}{l}\text { Meta- } \\
\text { Analysis }\end{array}$ & Authors' Conclusion & $\begin{array}{c}\text { Authors' } \\
\text { Judgement }\end{array}$ & $\begin{array}{c}\text { Our } \\
\text { Judgement }\end{array}$ & Comment \\
\hline \multicolumn{11}{|c|}{ OA Knee 10 reviews } \\
\hline $\begin{array}{l}\text { Ferronato et al. } \\
\text { [134] }\end{array}$ & $\begin{array}{l}\text { Physical modalities on the } \\
\text { functional performance in } \\
\text { knee osteoarthritis: a } \\
\text { systematic review }\end{array}$ & $\begin{array}{l}\text { Osteoarthritis- } \\
\text { knee }\end{array}$ & Chronic & SR & 13 & $\mathrm{~N}$ & $\begin{array}{l}\text { The use of TENS seems to be } \\
\text { as or more effective than } \\
\text { other analgesic therapies. } \\
\text { From } 11 \text { articles included in } \\
\text { this review, } 10 \text { articles } \\
\text { evaluated the beneficial } \\
\text { effects of TENS and } 1 \text { article } \\
\text { didn't notice increases in } \\
\text { comparison with the placebo } \\
\text { group }\end{array}$ & + & $?$ & \\
\hline Chen et al. [77] & $\begin{array}{l}\text { Transcutaneous Electrical } \\
\text { Nerve Stimulation in } \\
\text { Patients with Knee } \\
\text { Osteoarthritis Evidence from } \\
\text { Randomized-controlled } \\
\text { Trials }\end{array}$ & $\begin{array}{l}\text { Osteoarthritis- } \\
\text { knee }\end{array}$ & Chronic & SR & 23 & Y & $\begin{array}{l}\text { TENS might relieve pain due } \\
\text { to knee osteoarthritis. } \\
\text { Further } \\
\text { randomized-controlled trials } \\
\text { should focus on large-scale } \\
\text { studies and a longer } \\
\text { duration of follow-up. }\end{array}$ & $?$ & $?$ & \\
\hline $\begin{array}{c}\text { Cherian et al. } \\
{[80]}\end{array}$ & $\begin{array}{l}\text { The effects of various } \\
\text { physical non-operative } \\
\text { modalities on the pain in } \\
\text { osteoarthritis of the knee }\end{array}$ & $\begin{array}{l}\text { Osteoarthritis- } \\
\text { knee }\end{array}$ & Chronic & SR & 7 & $\mathrm{Y}$ & $\begin{array}{l}\text { In conclusion, all four } \\
\text { non-operative modalities } \\
\text { reduced the pain of OA of } \\
\text { the knee: neuromuscular } \\
\text { electrical stimulation and } \\
\text { TENS were the most } \\
\text { effective. }\end{array}$ & + & $?$ & \\
\hline Zeng et al. [76] & $\begin{array}{l}\text { Electrical stimulation for } \\
\text { pain relief in knee } \\
\text { osteoarthritis systematic } \\
\text { review and network } \\
\text { meta-analysis }\end{array}$ & $\begin{array}{l}\text { Osteoarthritis- } \\
\text { knee }\end{array}$ & Chronic & SR & 12 & Y & $\begin{array}{c}\text {... the recommendation } \\
\text { level of the other electrical } \\
\text { stimulation therapies is } \\
\text { either uncertain (h-TENS) or } \\
\text { not appropriate (l-TENS ... ) } \\
\text { for pain relief ... } \\
\text { Interferential currents seems } \\
\text { to be the most promising } \\
\text { pain relief treatment for the } \\
\text { management of knee OA }\end{array}$ & $?$ & $?$ & \\
\hline
\end{tabular}


Table 6. Cont.

\begin{tabular}{|c|c|c|c|c|c|c|c|c|c|c|}
\hline Ref. & Title & Condition & $\begin{array}{c}\text { Acute/Chronic } \\
\text { Pain }\end{array}$ & $\begin{array}{l}\text { Review } \\
\text { Type }\end{array}$ & $\begin{array}{l}\text { Number } \\
\text { of TENS } \\
\text { Studies }\end{array}$ & $\begin{array}{l}\text { Meta- } \\
\text { Analysis }\end{array}$ & Authors' Conclusion & $\begin{array}{c}\text { Authors' } \\
\text { Judgement }\end{array}$ & $\begin{array}{c}\text { Our } \\
\text { Judgement }\end{array}$ & Comment \\
\hline \multicolumn{11}{|c|}{ OA Knee 10 reviews } \\
\hline $\begin{array}{l}\text { Corbett et al. } \\
{[68]}\end{array}$ & $\begin{array}{l}\text { Acupuncture and other } \\
\text { physical treatments for the } \\
\text { relief of pain due to } \\
\text { osteoarthritis of the knee: } \\
\text { network meta-analysis }\end{array}$ & $\begin{array}{l}\text { Osteoarthritis- } \\
\text { knee }\end{array}$ & Chronic & SR & 18 & $\mathrm{Y}$ & $\begin{array}{l}\text { End of treatment results } \\
\text { showed that eight } \\
\text { interventions: interferential } \\
\text { therapy, acupuncture, TENS, } \\
\text { pulsed electrical stimulation, } \\
\text { balneotherapy, aerobic } \\
\text { exercise, sham acupuncture, } \\
\text { and muscle-strengthening } \\
\text { exercise produced a } \\
\text { statistically significant } \\
\text { reduction in pain when } \\
\text { compared with standard care } \\
\text {. . Our analyses found little } \\
\text { evidence (of significant } \\
\text { differences from standard } \\
\text { care, let alone } \\
\text { clinically-relevant } \\
\text { differences) to support such } \\
\text { guidance with respect to } \\
\text { treating pain, other than for } \\
\text { TENS, where the evidence } \\
\text { was of poor quality and } \\
\text { likely to be unreliable. }\end{array}$ & + & $?$ & \\
\hline Rutjes et al. [78] & $\begin{array}{l}\text { Transcutaneous } \\
\text { electrostimulation for } \\
\text { osteoarthritis of the knee } \\
\text { (Review) }\end{array}$ & $\begin{array}{l}\text { Osteoarthritis- } \\
\text { knee }\end{array}$ & Chronic & CR & 12 & Y & $\begin{array}{l}\text {... we could not confirm } \\
\text { that TENS is effective for } \\
\text { pain relief. The current } \\
\text { systematic review is } \\
\text { inconclusive, hampered by } \\
\text { the inclusion of only small } \\
\text { trials of questionable quality }\end{array}$ & $?$ & $?$ & $\begin{array}{l}\text { Update of Osiri } \\
\text { et al. [133]. We } \\
\text { included both } \\
\text { reviews because } \\
\text { conducted by } \\
\text { different teams. } \\
\text { There were } \\
4 \text { studies on } \\
\text { interferential } \\
\text { therapy included } \\
\text { in the analysis }\end{array}$ \\
\hline $\begin{array}{l}\text { Jamtvedt et al. } \\
\text { [54] }\end{array}$ & $\begin{array}{l}\text { Physical therapy } \\
\text { interventions for patients } \\
\text { with osteoarthritis of the } \\
\text { knee: an overview of } \\
\text { systematic reviews. }\end{array}$ & $\begin{array}{l}\text { osteoarthritis- } \\
\text { knee }\end{array}$ & Chronic & OSR & $\stackrel{0}{\mathrm{SR}}$ & $\mathrm{N}$ & $\begin{array}{l}\text { There is moderate-quality } \\
\text { evidence that acupuncture, } \\
\text { TENS, and low-level laser } \\
\text { therapy reduce pain .... }\end{array}$ & + & $?$ & \\
\hline
\end{tabular}


Table 6. Cont.

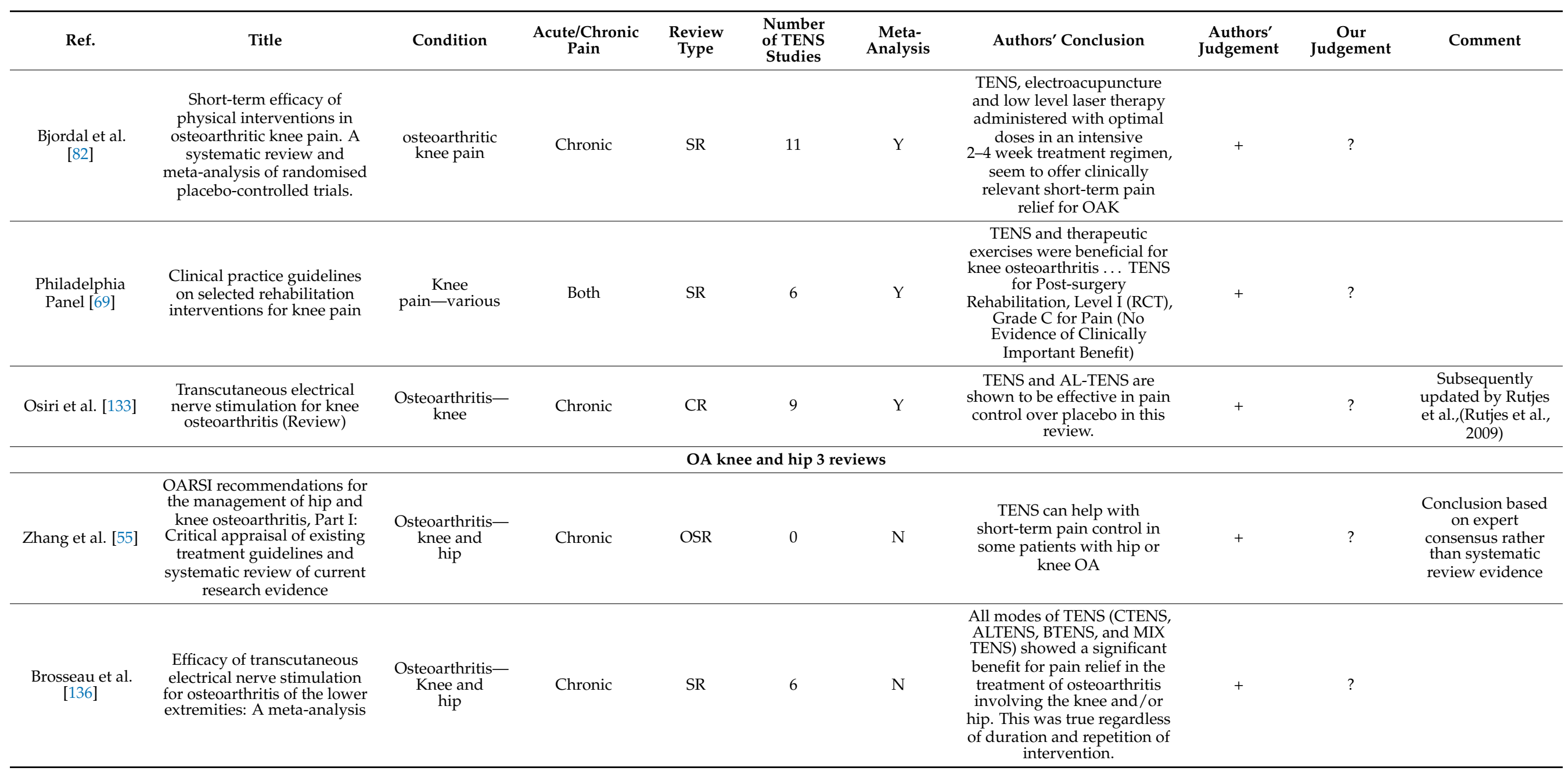


Table 6. Cont.

\begin{tabular}{|c|c|c|c|c|c|c|c|c|c|c|}
\hline Ref. & Title & Condition & $\begin{array}{c}\text { Acute/Chronic } \\
\text { Pain }\end{array}$ & $\begin{array}{l}\text { Review } \\
\text { Type }\end{array}$ & $\begin{array}{l}\text { Number } \\
\text { of TENS } \\
\text { Studies }\end{array}$ & $\begin{array}{l}\text { Meta- } \\
\text { Analysis }\end{array}$ & Authors' Conclusion & $\begin{array}{c}\text { Authors' } \\
\text { Judgement }\end{array}$ & $\begin{array}{c}\text { Our } \\
\text { Judgement }\end{array}$ & Comment \\
\hline \multicolumn{11}{|c|}{ OA knee and hip 3 reviews } \\
\hline Puett et al. [137] & $\begin{array}{l}\text { Published trials of } \\
\text { nonmedicinal and } \\
\text { non-invasive therapies for } \\
\text { hip and knee osteoarthritis }\end{array}$ & $\begin{array}{l}\text { Osteoarthritis- } \\
\text { knee and } \\
\text { hip }\end{array}$ & Chronic & SR & 3 & $\mathrm{~N}$ & $\begin{array}{l}\text { More data are needed to ... } \\
\text { evaluate the role of topical } \\
\text { capsaicin, laser therapy, } \\
\text { acupuncture, TENS, and } \\
\text { pulsed electromagnetic } \\
\text { fields. }\end{array}$ & $?$ & $?$ & \\
\hline
\end{tabular}

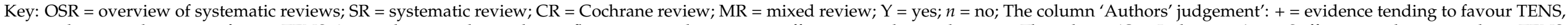

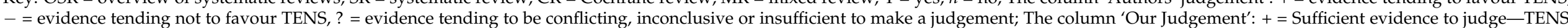
beneficial; - = Sufficient evidence to judge-TENS not beneficial; + / - = Sufficient evidence to judge-inconclusive; ? = Insufficient evidence to judge. 


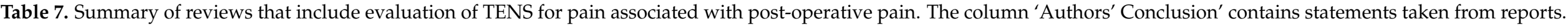

\begin{tabular}{|c|c|c|c|c|c|c|c|c|c|c|}
\hline Ref. & Title & Condition & $\begin{array}{l}\text { Acute/Chronic } \\
\text { Pain }\end{array}$ & $\begin{array}{l}\text { Review } \\
\text { Type }\end{array}$ & $\begin{array}{l}\text { Number } \\
\text { of TENS } \\
\text { Studies }\end{array}$ & MA & Authors' Conclusion & $\begin{array}{c}\text { Authors' } \\
\text { Judgement }\end{array}$ & $\begin{array}{c}\text { Our } \\
\text { Judgement }\end{array}$ & Comment \\
\hline $\begin{array}{l}\text { Zimpel et al. } \\
\text { [73] }\end{array}$ & $\begin{array}{l}\text { Complementary and } \\
\text { alternative therapies for } \\
\text { post-caesarean pain }\end{array}$ & $\begin{array}{l}\text { Postoperative } \\
\text { pain-caesarean }\end{array}$ & Acute & CR & 10 & Y & $\begin{array}{c}\text { TENS plus analgesia, } \\
\text { compared with placebo plus } \\
\text { analgesia, may reduce pain, } \\
\text { heart rate and respiratory } \\
\text { rate ... }\end{array}$ & + & $?$ & \\
\hline Zhou et al. [88] & $\begin{array}{l}\text { Efficacy of Transcutaneous } \\
\text { Electronic Nerve Stimulation } \\
\text { in Postoperative Analgesia } \\
\text { After Pulmonary Surgery: A } \\
\text { Systematic Review and } \\
\text { Meta-Analysis }\end{array}$ & $\begin{array}{l}\text { Postoperative } \\
\text { pain- } \\
\text { pulmonary }\end{array}$ & Acute & SR & 10 & Y & $\begin{array}{l}\text { Transcutaneous electronic } \\
\text { nerve stimulation might be } \\
\text { an effective supplementary } \\
\text { analgesic regimen in } \\
\text { multimodal analgesia to } \\
\text { decrease pain intensity after } \\
\text { pulmonary surgery }\end{array}$ & + & $?$ & \\
\hline $\begin{array}{c}\text { Terracina et al. } \\
{[138]}\end{array}$ & $\begin{array}{l}\text { Prevention and Treatment of } \\
\text { Postoperative Pain after } \\
\text { Lumbar Spine Procedures: A } \\
\text { Systematic Review }\end{array}$ & $\begin{array}{l}\text { Postoperative- } \\
\text { lumbar }\end{array}$ & Acute & SR & 2 & $\mathrm{~N}$ & $\begin{array}{c}\text { No statement of conclusion } \\
\text { for TENS }\end{array}$ & $?$ & $?$ & \\
\hline Yue et al. [139] & $\begin{array}{l}\text { Systematic Review of Three } \\
\text { Electrical Stimulation } \\
\text { Techniques for Rehabilitation } \\
\text { After Total Knee } \\
\text { Arthroplasty }\end{array}$ & $\begin{array}{l}\text { Postoperative } \\
\text { pain-knee } \\
\text { arthroplasty }\end{array}$ & Acute & SR & 7 & $\mathrm{~N}$ & $\begin{array}{c}\text { As adjunct modalities, } \\
\text { neuromuscular electrical } \\
\text { stimulation and TENS can } \\
\text { effectively improve } \\
\text { rehabilitation after total knee } \\
\text { arthroplasty }\end{array}$ & + & $?$ & $\begin{array}{l}\text { Analysis of } \\
\text { post-operative and } \\
\text { short-term } \\
\text { rehabilitation to } \\
12 \text { weeks }\end{array}$ \\
\hline Zhu et al. [75] & $\begin{array}{l}\text { Effect of TENS for pain } \\
\text { control after post op knee } \\
\text { arthroplasty }\end{array}$ & $\begin{array}{l}\text { Postoperative } \\
\text { pain-knee } \\
\text { arthroplasty }\end{array}$ & Acute & SR & 6 & Y & $\begin{array}{l}\text { Compared with control } \\
\text { intervention, TENS } \\
\text { supplementation } \\
\text { intervention was found to } \\
\text { significantly reduce pain and } \\
\text { morphine requirement over } \\
\text { a period of } 24 \mathrm{~h} \text { and to } \\
\text { promote functional recovery } \\
\text { in patients who have } \\
\text { undergone total knee } \\
\text { arthroplasty }\end{array}$ & + & $?$ & \\
\hline Li et al. [74] & $\begin{array}{l}\text { Transcutaneous electrical } \\
\text { nerve stimulation for } \\
\text { postoperative pain control } \\
\text { after total knee arthroplasty: } \\
\text { A meta-analysis of } \\
\text { randomized controlled trials. }\end{array}$ & $\begin{array}{l}\text { Postoperative } \\
\text { pain-knee } \\
\text { arthroplasty }\end{array}$ & Acute & SR & 5 & $\mathrm{Y}$ & $\begin{array}{l}\text { TENS could significantly } \\
\text { reduce pain and opioid } \\
\text { consumption after total knee } \\
\text { arthroplasty. In addition, } \\
\text { there were fewer adverse } \\
\text { effects in the TENS groups }\end{array}$ & + & $?$ & \\
\hline
\end{tabular}


Table 7. Cont.

\begin{tabular}{|c|c|c|c|c|c|c|c|c|c|c|}
\hline Ref. & Title & Condition & $\begin{array}{l}\text { Acute/Chronic } \\
\text { Pain }\end{array}$ & $\begin{array}{l}\text { Review } \\
\text { Type }\end{array}$ & $\begin{array}{l}\text { Number } \\
\text { of TENS } \\
\text { Studies }\end{array}$ & MA & Authors' Conclusion & $\begin{array}{c}\text { Authors' } \\
\text { Judgement }\end{array}$ & $\begin{array}{c}\text { Our } \\
\text { Judgement }\end{array}$ & Comment \\
\hline Kerai et al. [140] & $\begin{array}{l}\text { Role of transcutaneous } \\
\text { electrical nerve stimulation } \\
\text { in post-operative analgesia }\end{array}$ & $\begin{array}{l}\text { Postoperative } \\
\text { pain }\end{array}$ & Acute & SR & 8 & $\mathrm{~N}$ & $\begin{array}{l}\text { Most of the studies have } \\
\text { demonstrated clinically } \\
\text { significant reduction in pain } \\
\text { intensity and supplemental } \\
\text { analgesic requirement. } \\
\text { However, these trials vary in } \\
\text { TENS parameters used that } \\
\text { is, duration, intensity, } \\
\text { frequency of stimulation and } \\
\text { location of electrodes. }\end{array}$ & + & $?$ & \\
\hline Caley et al. [141] & $\begin{array}{l}\text { The effects of transcutaneous } \\
\text { electrical nerve stimulation } \\
\text { (TENS) in postoperative } \\
\text { cardiothoracic pain: a } \\
\text { systematic review. }\end{array}$ & $\begin{array}{c}\text { Postoperative } \\
\text { cardio-thoracic } \\
\text { pain } \\
\text { cardiothoracic }\end{array}$ & Acute & SR & 4 & $\mathrm{~N}$ & $\begin{array}{l}\text { All studies concluded TENS } \\
\text { to have no adverse effects } \\
\text { and to be beneficial in } \\
\text { post-operative pain ... firm } \\
\text { conclusions on the use of } \\
\text { TENS in this setting cannot } \\
\text { be made from this systematic } \\
\text { review }\end{array}$ & $?$ & $?$ & \\
\hline $\begin{array}{l}\text { Sbruzzi et al. } \\
\text { [89] }\end{array}$ & $\begin{array}{l}\text { Transcutaneous electrical } \\
\text { nerve stimulation after } \\
\text { thoracic surgery: systematic } \\
\text { review and meta-analysis of } \\
\text { randomized trials }\end{array}$ & $\begin{array}{l}\text { Postoperative } \\
\text { pain-thoracic }\end{array}$ & Acute & SR & 11 & $\mathrm{Y}$ & $\begin{array}{l}\text { TENS associated with } \\
\text { pharmacological analgesia } \\
\text { provides pain relief } \\
\text { compared to the placebo } \\
\text { TENS in postoperative } \\
\text { thoracic surgery patients } \\
\text { both approached by } \\
\text { thoracotomy and sternotomy. } \\
\text { In sternotomy it also } \\
\text { provides more effective pain } \\
\text { relief compared to } \\
\text { pharmacological analgesia } \\
\text { alone, but it has no } \\
\text { significant effect on } \\
\text { pulmonary function }\end{array}$ & + & $?$ & $\begin{array}{l}\text { Includes two } \\
\text { meta-analyses for } \\
\text { different surgeries } \\
\text { but does not } \\
\text { combine as one }\end{array}$ \\
\hline
\end{tabular}


Table 7. Cont.

\begin{tabular}{|c|c|c|c|c|c|c|c|c|c|c|}
\hline Ref. & Title & Condition & $\begin{array}{c}\text { Acute/Chronic } \\
\text { Pain }\end{array}$ & $\begin{array}{l}\text { Review } \\
\text { Type }\end{array}$ & $\begin{array}{l}\text { Number } \\
\text { of TENS } \\
\text { Studies }\end{array}$ & MA & Authors' Conclusion & $\begin{array}{c}\text { Authors' } \\
\text { Judgement }\end{array}$ & $\begin{array}{c}\text { Our } \\
\text { Judgement }\end{array}$ & Comment \\
\hline $\begin{array}{l}\text { Freynet et al. } \\
\text { [142] }\end{array}$ & $\begin{array}{l}\text { Is transcutaneous electrical } \\
\text { nerve stimulation effective in } \\
\text { relieving postoperative pain } \\
\text { after thoracotomy? }\end{array}$ & $\begin{array}{l}\text { Postoperative } \\
\text { pain- } \\
\text { thoracotomy }\end{array}$ & Acute & SR & 9 & $\mathrm{~N}$ & $\begin{array}{l}\text { Hence, current evidence } \\
\text { shows TENS associated with } \\
\text { postoperative medications to } \\
\text { be safe and effective in } \\
\text { alleviating postoperative } \\
\text { pain and in improving } \\
\text { patient recovery, thus } \\
\text { enhancing the choice of } \\
\text { available medical care and } \\
\text { bettering outcome after } \\
\text { thoracic surgery }\end{array}$ & + & $?$ & \\
\hline $\begin{array}{c}\text { Sabino et al. } \\
\text { [143] }\end{array}$ & $\begin{array}{l}\text { Transcutaneous Electrical } \\
\text { Nerve Stimulation in } \\
\text { Thoracic or Abdominal } \\
\text { Postoperative Conditions }\end{array}$ & $\begin{array}{l}\text { Postoperative } \\
\text { pain-thoracic } \\
\text { and abdominal }\end{array}$ & Acute & SR & 6 & $\mathrm{~N}$ & $\begin{array}{l}\text { TENS demonstrated specific } \\
\text { effectiveness for different } \\
\text { outcomes. The results of this } \\
\text { systematic review presented } \\
\text { no evidences to recommend } \\
\text { or reject the use of TENS for } \\
\text { functional recovery in the } \\
\text { postoperative period. The } \\
\text { use of distinct TENS } \\
\text { parameters, chosen in a } \\
\text { random and unjustified } \\
\text { form, made it impossible to } \\
\text { determine optimal } \\
\text { stimulation patterns }\end{array}$ & + & $?$ & \\
\hline $\begin{array}{c}\text { Bjordal et al. } \\
\text { [11] }\end{array}$ & $\begin{array}{l}\text { Transcutaneous electrical } \\
\text { nerve stimulation (TENS) } \\
\text { can reduce postoperative } \\
\text { analgesic consumption A } \\
\text { meta-analysis with } \\
\text { assessment of optimal } \\
\text { treatment parameters for } \\
\text { postoperative pain. }\end{array}$ & $\begin{array}{l}\text { Postoperative } \\
\text { pain-various }\end{array}$ & Acute & SR & 21 & Y & $\begin{array}{l}\text { TENS, administered with a } \\
\text { strong, subnoxious intensity } \\
\text { at an adequate frequency in } \\
\text { the wound area, can } \\
\text { significantly reduce } \\
\text { analgesic consumption for } \\
\text { postoperative pain }\end{array}$ & + & + & \\
\hline
\end{tabular}


Table 7. Cont.

\begin{tabular}{|c|c|c|c|c|c|c|c|c|c|c|}
\hline Ref. & Title & Condition & $\begin{array}{c}\text { Acute/Chronic } \\
\text { Pain }\end{array}$ & $\begin{array}{l}\text { Review } \\
\text { Type }\end{array}$ & $\begin{array}{l}\text { Number } \\
\text { of TENS } \\
\text { Studies }\end{array}$ & MA & Authors' Conclusion & $\begin{array}{c}\text { Authors' } \\
\text { Judgement }\end{array}$ & $\begin{array}{c}\text { Our } \\
\text { Judgement }\end{array}$ & Comment \\
\hline Carroll et al. [5] & $\begin{array}{c}\text { Randomization is important } \\
\text { in studies with pain } \\
\text { outcomes: systematic review } \\
\text { of transcutaneous electrical } \\
\text { nerve stimulation in acute } \\
\text { postoperative pain }\end{array}$ & $\begin{array}{l}\text { Postoperative } \\
\text { pain-various }\end{array}$ & Acute & SR & 17 & $\mathrm{~N}$ & $\begin{array}{l}\text { Fourteen of the } 17 \text { included } \\
\text { RCTs compared TENS with } \\
\text { sham TENS; no differences } \\
\text { were found. In } 17 \text { of these } 19 \\
\text { [non-randomised] TENS } \\
\text { studies, the authors } \\
\text { concluded that TENS had } \\
\text { appositive analgesic effect. }\end{array}$ & - & $?$ & $\begin{array}{l}\text { Non-randomized } \\
\text { studies } \\
\text { overestimated } \\
\text { treatment effects } \\
\text { Some of this data } \\
\text { also reported by } \\
\text { McQuay et al. [3] }\end{array}$ \\
\hline
\end{tabular}

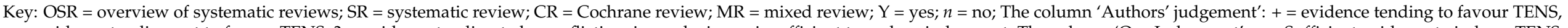

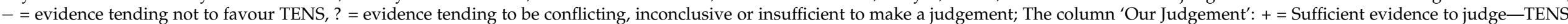
beneficial; - = Sufficient evidence to judge-TENS not beneficial; + / - = Sufficient evidence to judge-inconclusive; ? = Insufficient evidence to judge. 
More recently, meta-analyses have suggested that TENS is of benefit at relieving postoperative pain after thoracotomy and sternotomy [89,142], total knee arthroplasty [139], pulmonary surgery [88] and post-caesarean pain [73], although none of these had sufficient data to make a judgement according to our criteria. Zimpel et al. [73] claimed that TENS plus analgesia (versus placebo plus analgesia) reduced the intensity of post-caesarean pain (visual analogue scale) at one hour with a SMD of -1.10 (95\% CI -1.37 to $-0.82 ; 3$ studies; 238 women; low-certainty evidence). In summary, the evidence suggests that TENS is of benefit for postoperative pain.

\subsection{Labour Pain (10 Reviews)}

There were 10 reviews that included an evaluation for TENS for labour (Table 8). The earliest reviews of TENS for labour pain published in the mid-1990s were robust and reported that TENS did not alleviate pain nor reduce analgesic consumption $[98,144]$. In 2012, Jones et al. [25] published an overview of Cochrane reviews that evaluated pain management for women in labour including TENS and concluded that there was insufficient evidence to make a judgement based on one Cochrane review published by Dowswell et al. [22] in 2009. Dowswell et al. [22] included 18 studies and conducted a meta-analysis that pooled data two studies resulting in 143 participants in the TENS arm and 156 in the placebo/routine care arm with the SMD estimated to be -1.01 (95\% CI, $-3.00,0.97)$ for mean pain intensity during labour.

A report by the same team published three years later by Bedwell et al. [23] presented the same analysis, but SMD was reported to be $-0.16(95 \% \mathrm{CI}-0.39,0.07)$ for mean pain intensity during labour. We suspect that the substantial difference in the magnitude of the effect sizes estimates is due to reporting the findings of a random effects model by Dowswell et al. [22] and a fixed effects model by Bedwell et al. [23]. Dowswell et al. [22] reported a risk ratio of severe pain during labour between TENS and placebo/routine care of 0.67 ( $95 \%$ CI, $0.32,1.40$, random effects model) based on pooling of 79 events in the TENS arm and 68 events in the placebo/routine care arm, whereas Bedwell et al. [23] a risk ratio of 0.77 ( $95 \% \mathrm{CI}, 0.60,1.00, p=0.05)$. Again, we suspect the discrepancies in values to be due to the use of a fixed effect model in the latter analysis. This demonstrates the problem of discrepancies in effect size estimates reported within and between investigators, although this did not affect conclusions.

In 2020, Thuvarakan et al. [26] published a systematic review of 26 randomized controlled trials (3348 parturients) and a meta-analysis of 700 parturients in the TENS arm and 626 parturients in the control arm that found a small but statistically significant reduction in pain intensity during TENS with the risk ratio for participants experiencing moderate $(>30 \%)$ or a strong reduction in pain intensity $(>50 \%)$ as $1.52(95 \% \mathrm{CI}, 1.35,1.70)$ in favour of TENS, although the quality of studies was low. When judged against our criteria, this analysis provided sufficient data to support the efficacy of TENS.

Despite widespread use of TENS for pain during the early stages of childbirth, the NICE recommend that TENS should not be offered to women in established labour, although it may be beneficial in the early stages of labour [145]. 


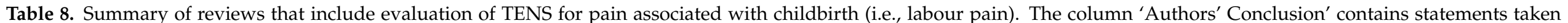
from reports.

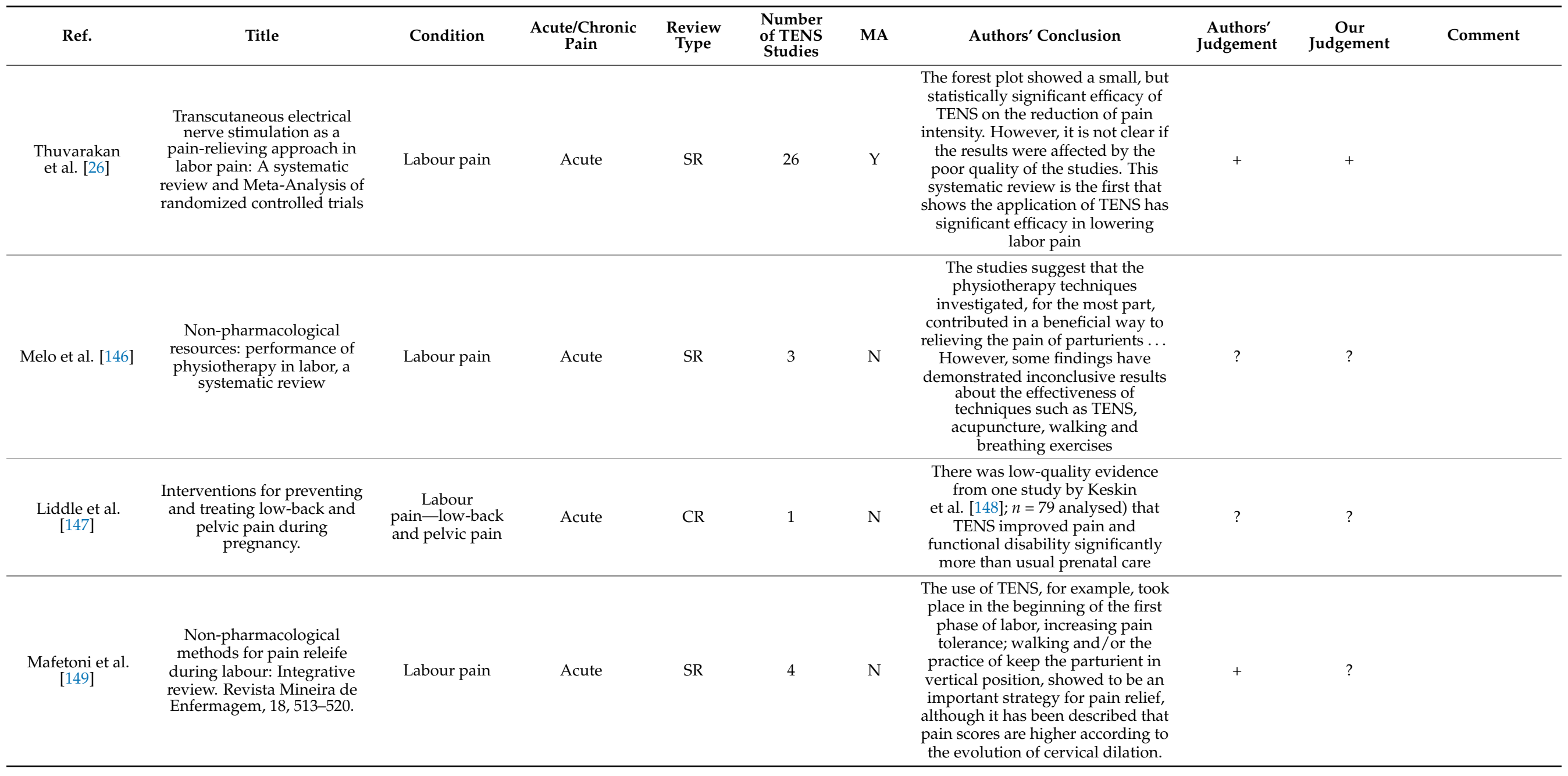


Table 8. Cont.

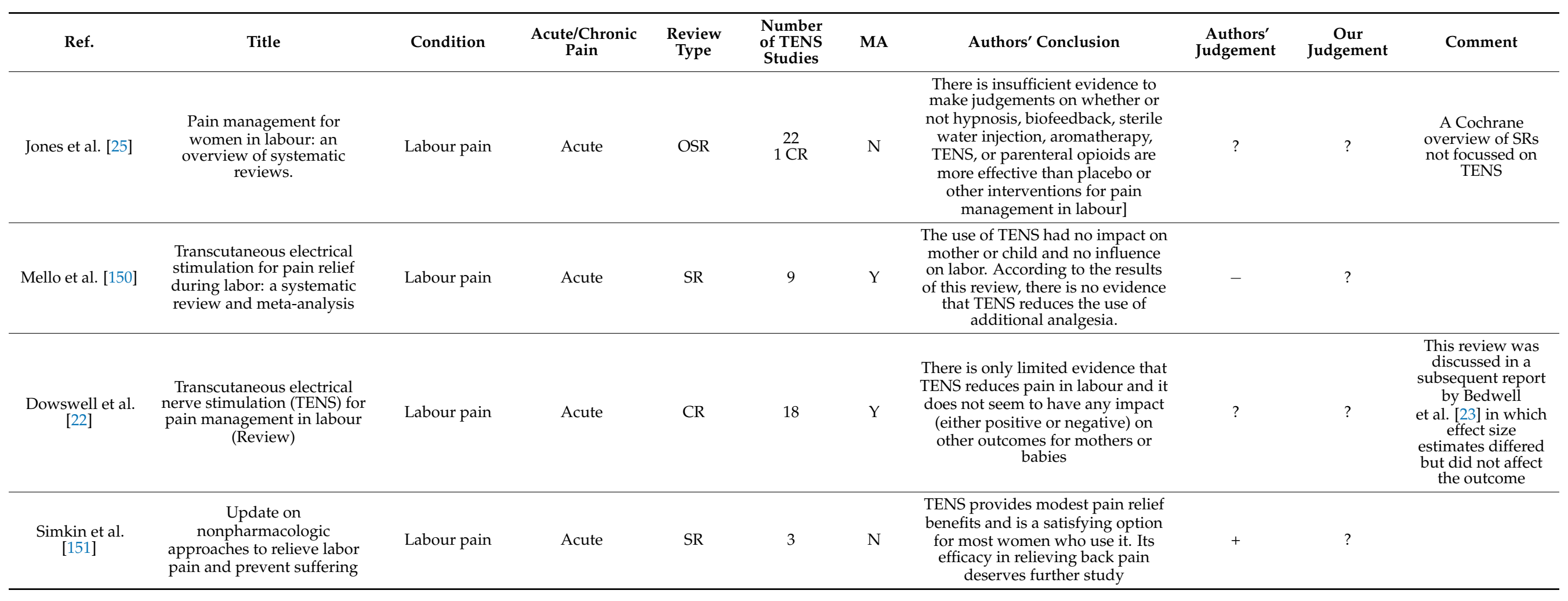


Table 8. Cont.

\begin{tabular}{|c|c|c|c|c|c|c|c|c|c|c|}
\hline Ref. & Title & Condition & $\begin{array}{l}\text { Acute/Chronic } \\
\text { Pain }\end{array}$ & $\begin{array}{l}\text { Review } \\
\text { Type }\end{array}$ & $\begin{array}{l}\text { Number } \\
\text { of TENS } \\
\text { Studies }\end{array}$ & MA & Authors' Conclusion & $\begin{array}{c}\text { Authors' } \\
\text { Judgement }\end{array}$ & $\begin{array}{c}\text { Our } \\
\text { Judgement }\end{array}$ & Comment \\
\hline $\begin{array}{l}\text { Carroll et al. } \\
\text { [144] }\end{array}$ & $\begin{array}{l}\text { Transcutaneous electrical } \\
\text { nerve stimulation does not } \\
\text { relieve labor pain: updated } \\
\text { systematic review }\end{array}$ & Labour pain & Acute & SR & 10 & $\mathrm{Y}$ & $\begin{array}{c}\text { The findings of this review suggest } \\
\text { that TENS has no significant effect } \\
\text { on pain in labour }\end{array}$ & - & $?$ & $\begin{array}{c}\text { Update of Carroll } \\
\text { et al. [152] and } \\
\text { data also reported } \\
\text { in McQuay et al. } \\
\text { [3] }\end{array}$ \\
\hline Reeve et al. [98] & $\begin{array}{l}\text { Transcutaneous electrical } \\
\text { nerve stimulation (TENS): a } \\
\text { technology assessment. }\end{array}$ & Labour pain & Acute & SR & 12 & $\mathrm{~N}$ & $\begin{array}{l}\text { The bulk of evidence in labour and } \\
\text { delivery indicates that TENS is not } \\
\text { effective }\end{array}$ & - & $?$ & $\begin{array}{l}\text { One report } \\
\text { containing } \\
3 \text { separate SRs }\end{array}$ \\
\hline
\end{tabular}

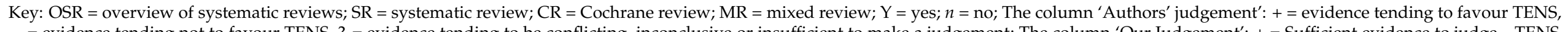

$-=$ evidence tending not to favour TENS, ? = evidence tending to be conflicting, inconclusive or insufficient to make a judgement; The column 'Our Ju 


\subsection{Dysmenorrhea (Seven Reviews) and Pelvic Pain (Four Reviews)}

There were 11 reviews that evaluated TENS for dysmenorrhea and/or pelvic pain (Table 9). There were seven reviews on dysmenorrhea (one of these was a Consensus Guideline [58]) and four reviews on a mixture of types of pelvic pain (some included dysmenorrhea). There were three hybrid reviews on TENS for dysmenorrhea [58-60]. In 2002, Proctor et al. [153] published a Cochrane review on TENS for primary dysmenorrhoea that included seven studies and claimed that high-frequency TENS was found beneficial, but there was insufficient evidence to determine the effectiveness of low-frequency TENS. In 2021, Arik et al. [70] published a systematic review and meta-analysis that included only four studies and concluded that TENS may be beneficial to alleviate pain in primary dysmenorrhea. It is interesting that the more recent review included fewer studies. We judged there to be insufficient data to make a judgement from all of the reviews on dysmenorrhea to date.

The most robust systematic review for chronic pelvic pain was published by Cottrell et al. [71] in 2020 and concluded that TENS was beneficial for women with chronic pelvic pain secondary to dysmenorrhea. Cottrell et al. [71] reported the overall effect size for data extracted for various neuromodulation treatments including percutaneous tibial nerve stimulation and transcutaneous interferential electrical stimulation that included 2 RCTs on TENS (87 participants), but did not report the effect size for TENS per se. Cottrell et al., conducted a separate analysis that pooled data from various neuromodulation techniques that included 4 non-RCTs on TENS (131 participants), but did not report the effect estimate for TENS per se. The 95\% confidence intervals for the effect size estimates of all TENS studies were in favour of TENS and did not cross the line of no difference, although according to our criteria there was insufficient data to make a judgement about efficacy. In 2018, Franco et al. [154] published a Cochrane review of non-pharmacological interventions for treating chronic prostatitis/chronic pelvic pain syndrome that included 2 studies on TENS, although the authors judged evidence to be inconclusive.

In summary, there are insufficient high-quality RCTs to judge the efficacy of TENS for dysmenorrhea or chronic pelvic pain.

\subsection{Fibromyalgia (Six Reviews)}

There were six reviews on fibromyalgia (Table 10). The most recent systematic review without meta-analysis was published in 2019 by Megia Garcia et al. [155] who claimed that TENS was beneficial for reducing pain in fibromyalgia, especially when added to therapeutic exercise, based on an evaluation of eight studies.

A Cochrane review of eight studies by Johnson et al. [156] was inconclusive due to insufficient high-quality evidence. A meta-analysis of five studies published by Salazar et al. [81] in 2017 concluded that electrical stimulation (using TENS or electroacupuncture) relieved pain in patients with fibromyalgia, although there were fewer than 200 participants were pooled and the sensitivity analysis suggested that TENS showed no effect. When judged against our criteria, none of these systematic reviews had sufficient data to make a judgement. Fibromyalgia is considered to be a chronic primary pain. The NICE guidelines for chronic primary pain do not recommend that TENS should be offered [157]. 


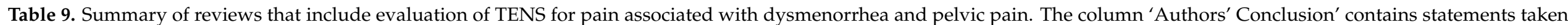
from reports.

\begin{tabular}{|c|c|c|c|c|c|c|c|c|c|c|}
\hline Ref. & Title & Condition & $\begin{array}{l}\text { Acute/Chronic } \\
\text { Pain }\end{array}$ & $\begin{array}{l}\text { Review } \\
\text { Type }\end{array}$ & $\begin{array}{l}\text { Number } \\
\text { of TENS } \\
\text { Studies }\end{array}$ & $\begin{array}{l}\text { Meta- } \\
\text { Analysis }\end{array}$ & Authors' Conclusion & $\begin{array}{c}\text { Authors' } \\
\text { Judgement }\end{array}$ & $\begin{array}{c}\text { Our } \\
\text { Judgement }\end{array}$ & Comment \\
\hline \multicolumn{11}{|c|}{ Pelvic pain } \\
\hline $\begin{array}{l}\text { Cottrell et al. } \\
\text { [71] }\end{array}$ & $\begin{array}{c}\text { Benefits and Harms of } \\
\text { Electrical } \\
\text { Neuromodulation for } \\
\text { Chronic Pelvic Pain: A } \\
\text { Systematic Review }\end{array}$ & Pelvic pain & Chronic & SR & 12 & $\mathrm{Y}$ & $\begin{array}{l}\text { TENS has been shown to be } \\
\text { an effective treatment for } \\
\text { women with chronic pelvic } \\
\text { pain secondary to } \\
\text { dysmenorrhea and is free } \\
\text { from adverse events, with } \\
\text { the advantage that it can be } \\
\text { self-applied and cost } \\
\text { effective }\end{array}$ & + & $?$ & $\begin{array}{l}\text { Review } \\
\text { included } \\
\text { studies on } \\
\text { dysmenor- } \\
\text { rhoea }\end{array}$ \\
\hline $\begin{array}{l}\text { Franco et al. } \\
\text { [154] }\end{array}$ & $\begin{array}{l}\text { Non-pharmacological } \\
\text { interventions for } \\
\text { treating chronic } \\
\text { prostatitis/chronic } \\
\text { pelvic pain syndrome }\end{array}$ & Pelvic pain & Chronic & $\mathrm{CR}$ & 2 & $\mathrm{Y}$ & $\begin{array}{l}\text { We were uncertain about } \\
\text { the effects of ... TENS, ... }\end{array}$ & $?$ & $?$ & \\
\hline $\begin{array}{l}\text { Cheong et al. } \\
\text { [158] }\end{array}$ & $\begin{array}{l}\text { Non-surgical } \\
\text { interventions for the } \\
\text { management of chronic } \\
\text { pelvic pain }\end{array}$ & Pelvic pain & Chronic & $\mathrm{CR}$ & 0 & $\mathrm{~N}$ & $\begin{array}{c}\text { No statement of conclusion } \\
\text { for TENS }\end{array}$ & $?$ & $?$ & \\
\hline $\begin{array}{l}\text { Cohen et al. } \\
\text { [159] }\end{array}$ & $\begin{array}{c}\text { Therapeutic } \\
\text { intervention for chronic } \\
\text { prostatitis/chronic } \\
\text { pelvic pain syndrome } \\
\text { (CP/CPPS): a } \\
\text { systematic review and } \\
\text { meta-analysis. }\end{array}$ & Pelvic pain & Chronic & SR & 0 & $\mathrm{~N}$ & $\begin{array}{c}\text { No statement of conclusion } \\
\text { for TENS }\end{array}$ & $?$ & $?$ & \\
\hline \multicolumn{11}{|c|}{ Dysmenorrhea } \\
\hline $\begin{array}{l}\text { Arik et al. } \\
\text { [70] }\end{array}$ & $\begin{array}{l}\text { The effect of TENS for } \\
\text { pain relief in women } \\
\text { with primary } \\
\text { dysmenorrhea: A } \\
\text { systematic review and } \\
\text { meta-analysis }\end{array}$ & Dysmenorrhea & Acute & SR & 4 & Y & $\begin{array}{l}\text { TENS is a safe and well } \\
\text { tolerated electrophysical } \\
\text { therapy that may be } \\
\text { effective for relieving pain } \\
\text { in primary dysmenorrhea }\end{array}$ & + & $?$ & \\
\hline
\end{tabular}


Table 9. Cont.

\begin{tabular}{|c|c|c|c|c|c|c|c|c|c|c|}
\hline Ref. & Title & Condition & $\begin{array}{l}\text { Acute/Chronic } \\
\text { Pain }\end{array}$ & $\begin{array}{l}\text { Review } \\
\text { Type }\end{array}$ & $\begin{array}{c}\text { Number } \\
\text { of TENS } \\
\text { Studies }\end{array}$ & $\begin{array}{l}\text { Meta- } \\
\text { Analysis }\end{array}$ & Authors' Conclusion & $\begin{array}{c}\text { Authors' } \\
\text { Judgement }\end{array}$ & $\begin{array}{c}\text { Our } \\
\text { Judgement }\end{array}$ & Comment \\
\hline \multicolumn{11}{|c|}{ Dysmenorrhea } \\
\hline $\begin{array}{c}\text { Igwea et al. } \\
{[160]}\end{array}$ & $\begin{array}{l}\text { TENS and heat therapy } \\
\text { for pain relief and } \\
\text { quality of life } \\
\text { improvement in } \\
\text { individuals with } \\
\text { primary dysmenorrhea: } \\
\text { A systematic review }\end{array}$ & Dysmenorrhea & Acute & SR & 6 & $\mathrm{~N}$ & $\begin{array}{l}\text { TENS and heat therapy } \\
\text { show potential as adjunct } \\
\text { remedies in the } \\
\text { management of primary } \\
\text { dysmenorrhea, but } \\
\text { rigorous high-quality trials } \\
\text { are still needed to make } \\
\text { conclusive } \\
\text { recommendation }\end{array}$ & $?$ & $?$ & \\
\hline $\begin{array}{c}\text { Latthe et al. } \\
\text { [59] }\end{array}$ & Dysmenorrhea & Dysmenorrhea & Acute & MR & 1 & $\mathrm{~N}$ & $\begin{array}{l}\text { High-frequency TENS may } \\
\text { reduce pain compared with } \\
\text { sham TENS but seems to be } \\
\text { less effective than } \\
\text { ibuprofen }\end{array}$ & + & $?$ & \\
\hline
\end{tabular}


Table 9. Cont.

\begin{tabular}{|c|c|c|c|c|c|c|c|c|c|c|}
\hline Ref. & Title & Condition & $\begin{array}{l}\text { Acute/Chronic } \\
\text { Pain }\end{array}$ & $\begin{array}{l}\text { Review } \\
\text { Type }\end{array}$ & $\begin{array}{l}\text { Number } \\
\text { of TENS } \\
\text { Studies }\end{array}$ & $\begin{array}{l}\text { Meta- } \\
\text { Analysis }\end{array}$ & Authors' Conclusion & $\begin{array}{c}\text { Authors' } \\
\text { Judgement }\end{array}$ & $\begin{array}{c}\text { Our } \\
\text { Judgement }\end{array}$ & Comment \\
\hline \multicolumn{11}{|c|}{ Dysmenorrhea } \\
\hline $\begin{array}{l}\text { Proctor and } \\
\text { Farquhar } \\
\text { [60] }\end{array}$ & Dysmenorrhea & Dysmenorrhea & Acute & MR & $2 \mathrm{SRs}$ & $\mathrm{N}$ & $\begin{array}{l}\text { High-frequency TENS } \\
\text { reduces pain compared } \\
\text { with placebo TENS } \\
\text { (moderate-quality } \\
\text { evidence). We don't know } \\
\text { whether low-frequency } \\
\text { TENS reduces pain } \\
\text { compared with placebo } \\
\text { TENS (low-quality } \\
\text { evidence). The } \\
\text { effectiveness of TENS is } \\
\text { unclear compared with } \\
\text { NSAIDs ... (very } \\
\text { low-quality evidence). }\end{array}$ & + & $?$ & \\
\hline $\begin{array}{c}\text { Proctor et al. } \\
\text { [153] }\end{array}$ & $\begin{array}{c}\text { Transcutaneous } \\
\text { electrical nerve } \\
\text { stimulation for primary } \\
\text { dysmenorrhoea } \\
\text { (Review) }\end{array}$ & Dysmenorrhoea & Acute & $\mathrm{CR}$ & 7 & Y & $\begin{array}{l}\text { High-frequency TENS was } \\
\text { found to be effective for the } \\
\text { treatment of } \\
\text { dysmenorrhoea by a } \\
\text { number of small trials. The } \\
\text { minor adverse effects } \\
\text { reported in one trial require } \\
\text { further investigation. There } \\
\text { is insufficient evidence to } \\
\text { determine the effectiveness } \\
\text { of low-frequency TENS in } \\
\text { reducing dysmenorrhoea }\end{array}$ & + & $?$ & $\begin{array}{c}\text { Subsequently } \\
\text { updated as a } \\
\text { MR by } \\
\text { Proctor and } \\
\text { Farquhar } \\
\text { [60] }\end{array}$ \\
\hline
\end{tabular}

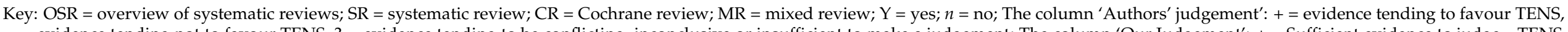

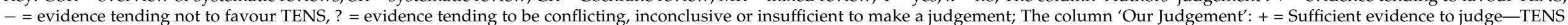
beneficial; $-=$ Sufficient evidence to judge - TENS not beneficial; + / - = Sufficient evidence to judge—inconclusive; $?=$ Insufficient evidence to judge. 
Table 10. Summary of reviews that include evaluation of TENS for pain associated with fibromyalgia. The column 'Authors' Conclusion' contains statements taken from reports.

\begin{tabular}{|c|c|c|c|c|c|c|c|c|c|c|}
\hline Ref. & Title & Condition & $\begin{array}{c}\text { Acute/Chronic } \\
\text { Pain }\end{array}$ & $\begin{array}{c}\text { Review } \\
\text { Type }\end{array}$ & $\begin{array}{l}\text { Number } \\
\text { of TENS } \\
\text { Studies }\end{array}$ & MA & Authors' Conclusion & $\begin{array}{c}\text { Authors' } \\
\text { Judgement }\end{array}$ & $\begin{array}{c}\text { Our } \\
\text { Judgement }\end{array}$ & Comment \\
\hline $\begin{array}{c}\text { Megia Garcia } \\
\text { et al. [155] }\end{array}$ & $\begin{array}{c}\text { Analgesic effects of } \\
\text { transcutaneous electrical } \\
\text { nerve stimulation (TENS) } \\
\text { in patients with } \\
\text { fibromyalgia A } \\
\text { systematic review }\end{array}$ & Fibromyalgia & Chronic & SR & 8 & $\mathrm{~N}$ & $\begin{array}{l}\text { Treatment with TENS is } \\
\text { effective for reducing pain in } \\
\text { people with fibromyalgia. In } \\
\text { addition, the inclusion of } \\
\text { TENS in therapeutic exercise } \\
\text { programs seems to have a } \\
\text { greater effect than practicing } \\
\text { therapeutic exercise in } \\
\text { isolation. Further studies are } \\
\text { needed to investigate the } \\
\text { optimization of the } \\
\text { parameters of the TENS and } \\
\text { a greater consensus among } \\
\text { the variables used. }\end{array}$ & + & $?$ & \\
\hline $\begin{array}{l}\text { Honda et al. } \\
\text { [162] }\end{array}$ & $\begin{array}{l}\text { Effects of Physical-Agent } \\
\text { Pain Relief Modalities for } \\
\text { Fibromyalgia Patients: A } \\
\text { Systematic Review and } \\
\text { Meta-Analysis of } \\
\text { Randomized Controlled } \\
\text { Trials }\end{array}$ & Fibromyalgia & Chronic & SR & 1 & $\mathrm{~N}$ & $\begin{array}{l}\text { TENS significantly reduced } \\
\text { visual analogue scale scores. } \\
\ldots \text { Effect of electromagnetic } \\
\text { therapy and TENS for the } \\
\text { treatment of fibromyalgia on } \\
\text { pain intensity was observed. }\end{array}$ & + & $?$ & \\
\hline $\begin{array}{c}\text { Ibanez-Vera } \\
\text { et al. [163] }\end{array}$ & $\begin{array}{l}\text { Passive physiotherapy for } \\
\text { the treatment of the } \\
\text { syndrome of } \\
\text { fibromyalgia. A } \\
\text { systematic review }\end{array}$ & Fibromyalgia & Chronic & SR & 4 & $\mathrm{~N}$ & $\begin{array}{l}\text { The quality of their subjects } \\
\text { with fibromyalgia seems to } \\
\text { be improving with ... TENS, } \\
\ldots \text { with a limited number of } \\
\text { studies }\end{array}$ & + & $?$ & \\
\hline $\begin{array}{c}\text { Johnson et al. } \\
\text { [156] }\end{array}$ & $\begin{array}{l}\text { Transcutaneous electrical } \\
\text { nerve stimulation (TENS) } \\
\text { for fibromyalgia in adults } \\
\text { (Review) }\end{array}$ & Fibromyalgia & Chronic & $\mathrm{CR}$ & 8 & $\mathrm{~N}$ & $\begin{array}{l}\text { There was insufficient } \\
\text { high-quality evidence to } \\
\text { support or refute the use of } \\
\text { TENS for fibromyalgia }\end{array}$ & $?$ & $?$ & \\
\hline
\end{tabular}


Table 10. Cont.

\begin{tabular}{|c|c|c|c|c|c|c|c|c|c|c|}
\hline Ref. & Title & Condition & $\begin{array}{l}\text { Acute/Chronic } \\
\text { Pain }\end{array}$ & $\begin{array}{l}\text { Review } \\
\text { Type }\end{array}$ & $\begin{array}{c}\text { Number } \\
\text { of TENS } \\
\text { Studies }\end{array}$ & MA & Authors' Conclusion & $\begin{array}{c}\text { Authors' } \\
\text { Judgement }\end{array}$ & $\begin{array}{c}\text { Our } \\
\text { Judgement }\end{array}$ & Comment \\
\hline $\begin{array}{c}\text { Salazar et al. } \\
\text { [81] }\end{array}$ & $\begin{array}{l}\text { Electric Stimulation for } \\
\text { Pain Relief in Patients } \\
\text { with Fibromyalgia: A } \\
\text { Systematic Review and } \\
\text { Meta-analysis of } \\
\text { Randomized Controlled } \\
\text { Trials }\end{array}$ & Fibromyalgia & Chronic & SR & 6 & Y & $\begin{array}{l}\text { Our meta-analyses showed } \\
\text { that electrical stimulation } \\
\text { (electroacupuncture + TENS) } \\
\text { in comparison with a control } \\
\text { group seems be effective for } \\
\text { pain relief in patients with } \\
\text { fibromyalgia. Additionally, } \\
\text { when we performed } \\
\text { sensitivity analysis of the } \\
\text { type of intervention, } \\
\text { electroacupuncture presented } \\
\text { favorable results toward the } \\
\text { experimental group } \\
\text { regarding pain relief, while } \\
\text { TENS showed no effect. }\end{array}$ & $?$ & $?$ & $\begin{array}{l}\text { Not sure } \\
\text { whether MD } \\
\text { relative to } \\
\text { baseline in } \\
\text { MA was in } \\
\mathrm{cm} \text { or mm }\end{array}$ \\
\hline $\begin{array}{l}\text { Ricci et al. } \\
\text { [164] }\end{array}$ & $\begin{array}{l}\text { The use of electrothermal } \\
\text { and phototherapeutic } \\
\text { methods for the } \\
\text { treatment of fibromyalgia } \\
\text { syndrome: a systematic } \\
\text { review }\end{array}$ & Fibromyalgia & Chronic & SR & 1 & $\mathrm{~N}$ & $\begin{array}{l}\text { [One study] had positive } \\
\text { outcomes after applying } \\
\text { TENS for pain control, } \\
\text { depression and quality of life } \\
\text { in FMS patients, despite the } \\
\text { fact that the sample of this } \\
\text { study was not representative }\end{array}$ & $?$ & $?$ & \\
\hline
\end{tabular}

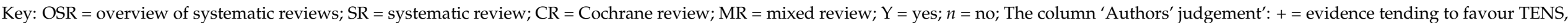

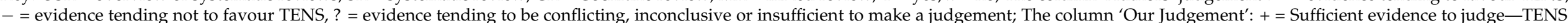
beneficial; - = Sufficient evidence to judge-TENS not beneficial; +/ - = Sufficient evidence to judge-inconclusive; ? = Insufficient evidence to judge. 


\subsection{Specific Shoulder Conditions (Five Reviews)}

There were five systematic reviews and we judged them all to have insufficient evidence (Table 11). In 2016, Page et al. [165] published a Cochrane review of electrotherapy modalities for rotator cuff disease that included eight studies on TENS that was inconclusive based on a descriptive analysis and concluded that without meta-analysis. Each of the other systematic reviews only included one study of TENS.

\subsection{Cancer and Its Treatment (Five Reviews)}

There were five reviews and we judged them all to have insufficient evidence (Table 12). There were two overviews of systematic reviews [166,167], and both were inconclusive basing their conclusions on the findings of the most recent Cochrane review by Hurlow et al. [168] published in 2012 that included two very small studies on TENS. Thus, there are insufficient high-quality RCTs to judge the efficacy of TENS for cancer and its treatment.

\subsection{Peripheral Diabetic Neuropathy (Five Reviews)}

There were five reviews on painful peripheral diabetic neuropathy (Table 13). The most recent review published Zeng et al. [169] was published in 2020 and included seven studies and a meta-analysis on that pooled data from various peripheral electrical stimulation techniques that failed to find differences with controls. However, the authors claimed that their subgroup analysis demonstrated "... a large effect for one of its subgroups (electrical peripheral techniques, predominantly TENS) ..." ", although the effect size for TENS per se was not reported and pooled samples did not reach our threshold for sufficient data to make a judgement. Overall, none of the reviews provided sufficient data to have confidence in judgements.

\subsection{Tendinitis/Tendinopathy (Four Reviews)}

There were four reviews on tendinitis/tendinopathy at the elbow or shoulder and we judged them all to have insufficient evidence (Table 14). The largest review was published in 2016 by Desmeules et al. [170] and included six studies on TENS for rotator cuff tendinopathy with evidence judged by the reviewers as insufficient and inconclusive.

\subsection{Post-Stroke Pain (4 Reviews)}

There were four reviews and we judged them all to have insufficient evidence (Table 15). A Cochrane review published in 2000 by Price and Pandyan [72] on electrical stimulation for preventing and treating post-stroke shoulder pain included four studies on TENS and did not confirm or refute that TENS around the shoulder reduced pain after stroke. The most recent review was published in 2016 by Chen et al. [171] and included only one study on TENS and concluded that the strength of evidence for benefit was 'poor'.

\subsection{Spinal Cord Injury (Four Reviews)}

There were four reviews and we judged them all to have insufficient evidence (Table 16). In 2016, Harvey et al. [172] published a systematic review on the effectiveness of 22 commonly administered physiotherapy interventions for people with spinal cord injury and found only two studies on TENS. Harvey et al. [172] judged the strength of evidence as low yet concluded that TENS was 'clearly effective'. In 2014, Boldt et al. [173] published a Cochrane review on non-pharmacological interventions for chronic pain in people with spinal cord injury was inconclusive. 
Table 11. Summary of reviews that include evaluation of TENS for pain specific shoulder pain. The column 'Authors' Conclusion' contains statements taken from reports.

\begin{tabular}{|c|c|c|c|c|c|c|c|c|c|c|}
\hline Ref. & Title & Condition & $\begin{array}{l}\text { Acute/Chronic } \\
\text { Pain }\end{array}$ & $\begin{array}{l}\text { Review } \\
\text { Type }\end{array}$ & $\begin{array}{l}\text { Number } \\
\text { of TENS } \\
\text { Studies }\end{array}$ & $\begin{array}{l}\text { Meta- } \\
\text { Analysis }\end{array}$ & Authors' Conclusion & $\begin{array}{c}\text { Authors' } \\
\text { Judgement }\end{array}$ & $\begin{array}{c}\text { Our } \\
\text { Judgement }\end{array}$ & Comment \\
\hline $\begin{array}{l}\text { Hawk et al. } \\
{[174]}\end{array}$ & $\begin{array}{c}\text { Systematic Review of } \\
\text { Nondrug, Nonsurgical } \\
\text { Treatment of Shoulder } \\
\text { Conditions }\end{array}$ & $\begin{array}{l}\text { Shoulder } \\
\text { Impingement }\end{array}$ & $?$ & SR & 1 & $\mathrm{~N}$ & $\begin{array}{l}\text { Evidence was inconclusive } \\
\text { because of the scarcity of studies }\end{array}$ & $?$ & $?$ & \\
\hline $\begin{array}{l}\text { Haik et al. } \\
\text { [175] }\end{array}$ & $\begin{array}{l}\text { Effectiveness of physical } \\
\text { therapy treatment of } \\
\text { clearly defined } \\
\text { subacromial pain: a } \\
\text { systematic review of } \\
\text { randomised controlled } \\
\text { trials }\end{array}$ & $\begin{array}{l}\text { Subacromial } \\
\text { pain }\end{array}$ & Both & SR & 1 & $\mathrm{~N}$ & $\begin{array}{l}\text { Microwave diathermy and TENS } \\
\text { do not seem to be beneficial in } \\
\text { SAPS [subacromial pain] } \\
\text { treatment. The evidence is still } \\
\text { low due to the low number of } \\
\text { participants and studies } \\
\text { available in the literature }\end{array}$ & - & $?$ & \\
\hline $\begin{array}{l}\text { Page et al. } \\
\text { [176] }\end{array}$ & $\begin{array}{l}\text { Electrotherapy modalities } \\
\text { for rotator cuff disease } \\
\text { (Review) }\end{array}$ & $\begin{array}{l}\text { Rotator cuff } \\
\text { disease }\end{array}$ & Both & $\mathrm{CR}$ & 8 & $\mathrm{~N}$ & $\begin{array}{l}\text { We are uncertain whether TENS } \\
\text { is superior to placebo, and } \\
\text { whether any electrotherapy } \\
\text { modality provides benefits over } \\
\text { other active interventions (e.g., } \\
\text { glucocorticoid injection) because } \\
\text { of the very low quality of the } \\
\text { evidence. due to the high risk of } \\
\text { performance and detection bias } \\
\text { (downgraded by two points) and } \\
\text { imprecision (downgraded by one } \\
\text { point) }\end{array}$ & $?$ & $?$ & \\
\hline $\begin{array}{l}\text { Page et al. } \\
\text { [177] }\end{array}$ & $\begin{array}{l}\text { Electrotherapy modalities } \\
\text { for adhesive capsulitis } \\
\text { (frozen shoulder) }\end{array}$ & $\begin{array}{l}\text { Adhesive } \\
\text { capsulitis }\end{array}$ & Both & $\mathrm{CR}$ & 1 & $\mathrm{~N}$ & $\begin{array}{c}\text { Overall, based on very } \\
\text { low-quality evidence, we are } \\
\text { uncertain whether a combination } \\
\text { of therapeutic ultrasound, TENS } \\
\text { and hot packs is an effective } \\
\text { adjunct to exercise }\end{array}$ & $?$ & $?$ & \\
\hline $\begin{array}{l}\text { Johansson } \\
\text { et al. [178] }\end{array}$ & $\begin{array}{l}\text { A combination of } \\
\text { systematic review and } \\
\text { clinicians' beliefs in } \\
\text { interventions for } \\
\text { subacromial pain }\end{array}$ & $\begin{array}{l}\text { Subacromial } \\
\text { pain }\end{array}$ & $\mathrm{UC}$ & SR & 1 & $\mathrm{~N}$ & $\begin{array}{l}\text {... there is no available } \\
\text { evidence for efficacy of TENS for } \\
\text { patients with subacromial pain }\end{array}$ & $?$ & $?$ & \\
\hline
\end{tabular}

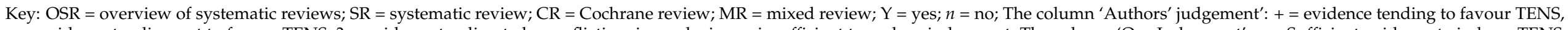

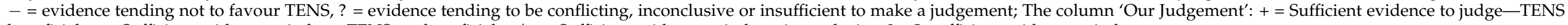
beneficial; - = Sufficient evidence to judge—TENS not beneficial; + / - = Sufficient evidence to judge—inconclusive; $?=$ Insufficient evidence to judge 


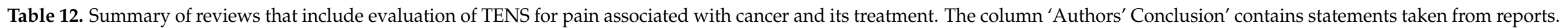

\begin{tabular}{|c|c|c|c|c|c|c|c|c|c|c|}
\hline Ref. & Title & Condition & $\begin{array}{l}\text { Acute/Chronic } \\
\text { Pain }\end{array}$ & $\begin{array}{c}\text { Review } \\
\text { Type }\end{array}$ & $\begin{array}{l}\text { No. } \\
\text { TENS } \\
\text { Studies }\end{array}$ & MA & Authors' Conclusion & $\begin{array}{c}\text { Authors' } \\
\text { Judgement }\end{array}$ & $\begin{array}{c}\text { Our } \\
\text { Judgement }\end{array}$ & Comment \\
\hline $\begin{array}{c}\text { Wu et al. } \\
\text { [166] }\end{array}$ & $\begin{array}{l}\text { Effectiveness of } \\
\text { acupuncture and } \\
\text { related therapies for } \\
\text { palliative care of cancer: } \\
\text { overview of systematic } \\
\text { reviews }\end{array}$ & Cancer & Both & OSR & 0 & $\mathrm{~N}$ & $\begin{array}{c}\text { No statement of conclusion for } \\
\text { TENS }\end{array}$ & $?$ & $?$ & \\
\hline $\begin{array}{c}\text { Hökkä et al. } \\
\text { [179] }\end{array}$ & $\begin{array}{l}\text { A systematic review: } \\
\text { non-pharmacological } \\
\text { interventions in treating } \\
\text { pain in patients with } \\
\text { advanced cancer }\end{array}$ & Cancer & Chronic & SR & 1 & $\mathrm{~N}$ & $\begin{array}{l}\text { With just one limited study, it is } \\
\text { not possible to draw conclusions } \\
\text { about the safety and potential of } \\
\text { TENS to reduce pain }\end{array}$ & $?$ & $?$ & \\
\hline $\begin{array}{l}\text { Hurlow et al. } \\
\text { [168] }\end{array}$ & $\begin{array}{l}\text { Transcutaneous electric } \\
\text { nerve stimulation } \\
\text { (TENS) for cancer pain } \\
\text { in adults (Review) }\end{array}$ & Cancer pain & Chronic & $\mathrm{CR}$ & 2 & $\mathrm{~N}$ & $\begin{array}{l}\text {... the results of this updated } \\
\text { systematic review remain } \\
\text { inconclusive due to a lack of } \\
\text { suitable RCTs }\end{array}$ & $?$ & $?$ & $\begin{array}{l}\text { Updated } \\
\text { review of } \\
\text { Robb et al. } \\
\quad[180]\end{array}$ \\
\hline $\begin{array}{c}\text { Pan et al. } \\
\text { [181] }\end{array}$ & $\begin{array}{l}\text { Complementary and } \\
\text { Alternative Medicine in } \\
\text { the Management of } \\
\text { Pain, Dyspnea, and } \\
\text { Nausea and Vomiting } \\
\text { Near the End of Life: A } \\
\text { Systematic Review }\end{array}$ & Cancer pain & Chronic & SR & 1 & $\mathrm{~N}$ & $\begin{array}{l}\text { Case series and a small RCT } \\
\text { suggest that TENS may provide } \\
\text { short-term pain relief in dying } \\
\text { patients or in patients with } \\
\text { intractable cancer pain. TENS may } \\
\text { provide short-term pain relief in } \\
\text { patients with intractable or } \\
\text { advanced cancer pain }\end{array}$ & + & $?$ & \\
\hline
\end{tabular}

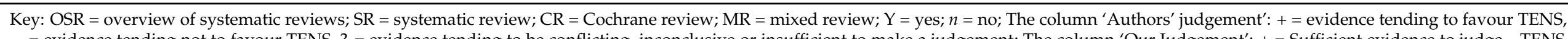

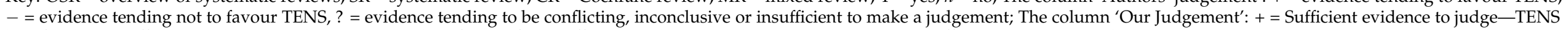
beneficial; $-=$ Sufficient evidence to judge - TENS not beneficial; + / $-=$ Sufficient evidence to judge—inconclusive; $?=$ Insufficient evidence to judge. 


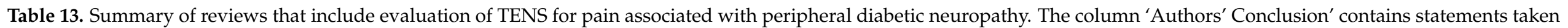
from reports.

\begin{tabular}{|c|c|c|c|c|c|c|c|c|c|c|}
\hline Ref. & Title & Condition & $\begin{array}{c}\text { Acute/Chronic } \\
\text { Pain }\end{array}$ & $\begin{array}{c}\text { Review } \\
\text { Type }\end{array}$ & $\begin{array}{l}\text { Number } \\
\text { of TENS } \\
\text { Studies }\end{array}$ & $\begin{array}{l}\text { Meta- } \\
\text { Analysis }\end{array}$ & Authors' Conclusion & $\begin{array}{l}\text { Authors' } \\
\text { Judge- } \\
\text { ment }\end{array}$ & $\begin{array}{l}\text { Our } \\
\text { Judge- } \\
\text { ment }\end{array}$ & Comment \\
\hline $\begin{array}{l}\text { Zeng et al. } \\
\text { [169] }\end{array}$ & $\begin{array}{c}\text { Non-invasive } \\
\text { neuromodulation } \\
\text { effects on painful } \\
\text { diabetic peripheral } \\
\text { neuropathy: a } \\
\text { systematic review and } \\
\text { meta-analysis }\end{array}$ & $\begin{array}{l}\text { Diabetic } \\
\text { peripheral } \\
\text { neuropathy }\end{array}$ & Chronic & SR & 7 & Y & $\begin{array}{l}\text { We found a consistent medium } \\
\text { to large effect size on pain } \\
\text { reduction by central techniques, } \\
\text { but no significant effects for the } \\
\text { overall peripheral techniques, } \\
\text { although we found a large } \\
\text { effect for one of its subgroups } \\
\text { (electrical peripheral } \\
\text { techniques, predominantly } \\
\text { TENS) }\end{array}$ & + & $?$ & \\
\hline $\begin{array}{l}\text { Stein et al. } \\
\text { [65] }\end{array}$ & $\begin{array}{l}\text { Electrical stimulation } \\
\text { and electromagnetic } \\
\text { field use in patients } \\
\text { with diabetic } \\
\text { neuropathy: } \\
\text { systematic review and } \\
\text { meta-analysis }\end{array}$ & $\begin{array}{l}\text { Diabetic } \\
\text { peripheral } \\
\text { neuropathy }\end{array}$ & Both & SR & 5 & $\mathrm{Y}$ & $\begin{array}{l}\text { We found that TENS improved } \\
\text { pain relief in patients with } \\
\text { diabetic neuropathy, while no } \\
\text { such improvement was } \\
\text { observed with the use of } \\
\text { electromagnetic field treatment. } \\
\text { The limited number of studies } \\
\text {... demonstrate the need for } \\
\text { further randomized clinical } \\
\text { trials. }\end{array}$ & + & $?$ & \\
\hline $\begin{array}{l}\text { Dubinsky } \\
\text { et al. [115] }\end{array}$ & $\begin{array}{l}\text { Assessment: Efficacy } \\
\text { of transcutaneous } \\
\text { electric nerve } \\
\text { stimulation in the } \\
\text { treatment of pain in } \\
\text { neurologic disorders } \\
\text { (an evidence-based } \\
\text { review) }\end{array}$ & $\begin{array}{l}\text { Diabetic } \\
\text { peripheral } \\
\text { neuropathy }\end{array}$ & Chronic & SR & 3 & $\mathrm{~N}$ & $\begin{array}{l}\text { TENS should be considered in } \\
\text { the treatment of painful } \\
\text { diabetic neuropathy (Level B) }\end{array}$ & + & $?$ & $\begin{array}{l}\text { Conducted } \\
\text { two analyses } \\
\text { in same } \\
\text { report-this is } \\
\text { data for } \\
\text { peripheral } \\
\text { diabetic } \\
\text { neuropathy }\end{array}$ \\
\hline
\end{tabular}


Table 13. Cont.

\begin{tabular}{|c|c|c|c|c|c|c|c|c|c|c|}
\hline Ref. & Title & Condition & $\begin{array}{l}\text { Acute/Chronic } \\
\text { Pain }\end{array}$ & $\begin{array}{l}\text { Review } \\
\text { Type }\end{array}$ & $\begin{array}{l}\text { Number } \\
\text { of TENS } \\
\text { Studies }\end{array}$ & $\begin{array}{l}\text { Meta- } \\
\text { Analysis }\end{array}$ & Authors' Conclusion & $\begin{array}{l}\text { Authors' } \\
\text { Judge- } \\
\text { ment }\end{array}$ & $\begin{array}{l}\text { Our } \\
\text { Judge- } \\
\text { ment }\end{array}$ & Comment \\
\hline Jin et al. [66] & $\begin{array}{c}\text { Effect of } \\
\text { transcutaneous } \\
\text { electrical nerve } \\
\text { stimulation on } \\
\text { symptomatic diabetic } \\
\text { peripheral } \\
\text { neuropathy: A } \\
\text { meta-analysis of } \\
\text { randomized } \\
\text { controlled trials }\end{array}$ & $\begin{array}{l}\text { Diabetic } \\
\text { peripheral } \\
\text { neuropathy }\end{array}$ & Chronic & SR & 3 & $\mathrm{Y}$ & $\begin{array}{l}\text { TENS therapy may be an } \\
\text { effective and safe strategy in } \\
\text { treatment of symptomatic } \\
\text { diabetic peripheral neuropathy }\end{array}$ & + & $?$ & \\
\hline $\begin{array}{l}\text { Pieber et al. } \\
\text { [182] }\end{array}$ & $\begin{array}{l}\text { Electrotherapy for the } \\
\text { treatment of painful } \\
\text { diabetic peripheral } \\
\text { neuropathy: a review }\end{array}$ & $\begin{array}{l}\text { Diabetic } \\
\text { peripheral } \\
\text { neuropathy }\end{array}$ & Chronic & SR & 5 & $\mathrm{~N}$ & $\begin{array}{l}\text {... the effects of TENS are } \\
\text { consistent. The beneficial } \\
\text { effects of prolonged use have } \\
\text { been reported in three large } \\
\text { studies and one small } \\
\text { study.-TENS may be } \\
\text { recommended for the } \\
\text { treatment of PN. }\end{array}$ & + & $?$ & \\
\hline
\end{tabular}

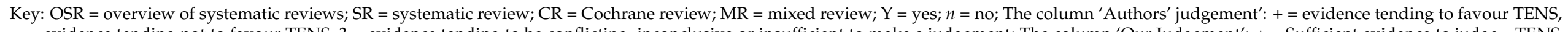

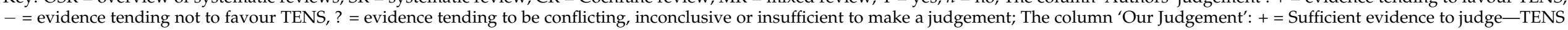
beneficial; - = Sufficient evidence to judge-TENS not beneficial; + / - = Sufficient evidence to judge - inconclusive; $?=$ Insufficient evidence to judge 
Table 14. Summary of reviews that include evaluation of TENS for tendinitis/tendinopathy. The column 'Authors' Conclusion' contains statements taken from reports.

\begin{tabular}{|c|c|c|c|c|c|c|c|c|c|c|}
\hline Ref. & Title & Condition & $\begin{array}{c}\text { Acute/Chronic } \\
\text { Pain }\end{array}$ & $\begin{array}{l}\text { Review } \\
\text { Type }\end{array}$ & $\begin{array}{l}\text { Number } \\
\text { of TENS } \\
\text { Studies }\end{array}$ & $\begin{array}{l}\text { Meta- } \\
\text { Analysis }\end{array}$ & Authors' Conclusion & $\begin{array}{c}\text { Authors' } \\
\text { Judgement }\end{array}$ & $\begin{array}{c}\text { Our } \\
\text { Judgement }\end{array}$ & Comment \\
\hline Dion et al. [183] & $\begin{array}{l}\text { Are passive physical } \\
\text { modalities effective for the } \\
\text { management of common } \\
\text { soft tissue injuries of the } \\
\text { elbow? A systematic } \\
\text { review by the Ontario } \\
\text { Protocol for Traffic Injury } \\
\text { Management (OPTIMa) } \\
\text { Collaboration }\end{array}$ & $\begin{array}{l}\text { Tendinitis/Soft } \\
\text { tissue } \\
\text { injuries—elbow }\end{array}$ & UC & SR & 2 & $\mathrm{~N}$ & $\begin{array}{l}\text {... TENS provides no added } \\
\text { benefit to patients with lateral } \\
\text { epicondylitis. We found } \\
\text { evidence from one low risk of } \\
\text { bias RCT that TENS is not } \\
\text { effective for the management } \\
\text { of lateral epicondylitis }\end{array}$ & - & $?$ & \\
\hline Wu et al. [184] & $\begin{array}{c}\text { Comparative Effectiveness } \\
\text { of Nonoperative } \\
\text { Treatments for Chronic } \\
\text { Calcific Tendinitis of the } \\
\text { Shoulder: A Systematic } \\
\text { Review and Network } \\
\text { Meta-Analysis of } \\
\text { Randomized Controlled } \\
\text { Trials }\end{array}$ & $\begin{array}{c}\text { Tendinitis- } \\
\text { Shoulder, } \\
\text { Chronic Calcific }\end{array}$ & Chronic & SR & 1 & $\mathrm{Y}$ & $\begin{array}{l}\text { Compared with low-energy } \\
\text { focused extracorporeal } \\
\text { shockwave therapy, TENS, and } \\
\text { ultrasound therapy, } \\
\text { H-FSW is the best therapy for } \\
\text { providing functional recovery }\end{array}$ & $?$ & $?$ & \\
\hline $\begin{array}{l}\text { Desmeules et al. } \\
{[170]}\end{array}$ & $\begin{array}{c}\text { Efficacy of transcutaneous } \\
\text { electrical nerve stimulation } \\
\text { for rotator cuff } \\
\text { tendinopathy: a systematic } \\
\text { review }\end{array}$ & $\begin{array}{l}\text { Tendinopathy- } \\
\text { rotator } \\
\text { cuff }\end{array}$ & $\mathrm{UC}$ & SR & 6 & $\mathrm{~N}$ & $\begin{array}{l}\text {... no conclusions can be } \\
\text { drawn on the efficacy of TENS } \\
\text { for the treatment of rotator cuff } \\
\text { tendinopathy }\end{array}$ & $?$ & $?$ & $\begin{array}{c}\text { We } \\
\text { categorised } \\
\text { this study as } \\
\text { tendinopathy } \\
\text { rather than } \\
\text { specific } \\
\text { shoulder }\end{array}$ \\
\hline $\begin{array}{l}\text { Dingemanse } \\
\text { et al. [185] }\end{array}$ & $\begin{array}{l}\text { Evidence for the } \\
\text { effectiveness of } \\
\text { electrophysical modalities } \\
\text { for treatment of medial } \\
\text { and lateral epicondylitis: a } \\
\text { systematic review }\end{array}$ & $\begin{array}{c}\text { Lateral } \\
\text { epicondylitis }\end{array}$ & Chronic & SR & 2 & $\mathrm{~N}$ & $\begin{array}{l}\text {... evidence of no difference } \\
\text { in the effect of electrotherapy } \\
\text { versus placebo was found }\end{array}$ & $?$ & ? & $\begin{array}{l}\text { (Update of } \\
\text { Dingemanse } \\
\text { et al. [185]) }\end{array}$ \\
\hline
\end{tabular}

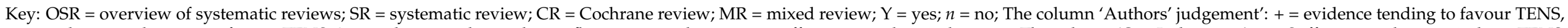

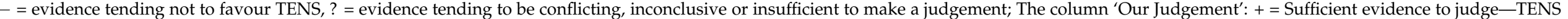
beneficial; $-=$ Sufficient evidence to judge -TENS not beneficial; + / - = Sufficient evidence to judge—inconclusive; $?=$ Insufficient evidence to judge 
Table 15. Summary of reviews that include evaluation of TENS for post stroke pain. The column 'Authors' Conclusion' contains statements taken from reports.

\begin{tabular}{|c|c|c|c|c|c|c|c|c|c|c|}
\hline Ref. & Title & Condition & $\begin{array}{c}\text { Acute/Chronic } \\
\text { Pain }\end{array}$ & $\begin{array}{l}\text { Review } \\
\text { Type }\end{array}$ & $\begin{array}{c}\text { Number } \\
\text { of TENS } \\
\text { Studies }\end{array}$ & $\begin{array}{l}\text { Meta- } \\
\text { Analysis }\end{array}$ & Authors' Conclusion & $\begin{array}{c}\text { Authors' } \\
\text { Judgement }\end{array}$ & $\begin{array}{c}\text { Our } \\
\text { Judgement }\end{array}$ & Comment \\
\hline $\begin{array}{c}\text { Chen et al. } \\
\text { [171] }\end{array}$ & $\begin{array}{l}\text { The antalgic effects of } \\
\text { non-invasive physical } \\
\text { modalities on central } \\
\text { post-stroke pain: a } \\
\text { systematic review }\end{array}$ & $\begin{array}{l}\text { Post-stroke } \\
\text { pain }\end{array}$ & Chronic & SR & 1 & $\mathrm{~N}$ & $\begin{array}{c}\ldots \text { the strength for its } \\
\text { efficacy was poor and it } \\
\text { was only effective for some } \\
\text { of central post-stroke pain } \\
\text { patients }\end{array}$ & $?$ & $?$ & \\
\hline $\begin{array}{l}\text { Ramos- } \\
\text { Valero et al. } \\
\text { [186] }\end{array}$ & $\begin{array}{c}\text { Physiotherapy } \\
\text { treatments for patients } \\
\text { with shoulder pain after } \\
\text { stroke. A systematic } \\
\text { review }\end{array}$ & $\begin{array}{l}\text { Post stroke } \\
\text { pain- } \\
\text { shoulder }\end{array}$ & Both & SR & 1 & $\mathrm{~N}$ & $\begin{array}{l}\text { These results indicate that } \\
\text { this [TENS] technique does } \\
\text { not only deal with the } \\
\text { symptoms... }\end{array}$ & - & $?$ & \\
\hline $\begin{array}{c}\text { Barreca et al. } \\
\text { [57] }\end{array}$ & $\begin{array}{l}\text { Interventions for the } \\
\text { paretic upper limb of } \\
\text { stroke survivors: }\end{array}$ & $\begin{array}{l}\text { Post stroke } \\
\text { pain }\end{array}$ & Chronic & MR & $\begin{array}{c}4 \\
1 \mathrm{SR}\end{array}$ & $\mathrm{N}$ & $\begin{array}{l}\text {... careful handling, } \\
\text { electrical stimulation, } \\
\text { movement with elevation, } \\
\text { strapping, and the } \\
\text { avoidance of overhead } \\
\text { pulleys could effectively } \\
\text { reduce or prevent pain in } \\
\text { the paretic upper limb }\end{array}$ & + & $?$ & $\begin{array}{l}\text { This } \\
\text { systematic } \\
\text { review } \\
\text { focussed on } \\
\text { motor } \\
\text { impairment } \\
\text { after stroke }\end{array}$ \\
\hline $\begin{array}{l}\text { Price and } \\
\text { Pandyan } \\
\text { [72] }\end{array}$ & $\begin{array}{l}\text { Electrical stimulation } \\
\text { for preventing and } \\
\text { treating post-stroke } \\
\text { shoulder pain }\end{array}$ & $\begin{array}{l}\text { Post-stroke } \\
\text { pain- } \\
\text { shoulder }\end{array}$ & Both & $\mathrm{CR}$ & 4 & $\mathrm{Y}$ & $\begin{array}{l}\text { The evidence ... does not } \\
\text { confirm or refute that } \\
\text { electrical stimulation } \\
\text { around the shoulder after } \\
\text { stroke influences reports of } \\
\text { pain, but there do appear to } \\
\text { be benefits for passive } \\
\text { humeral lateral rotation }\end{array}$ & $?$ & $?$ & \\
\hline
\end{tabular}

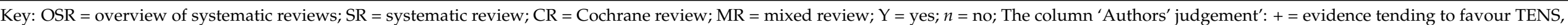

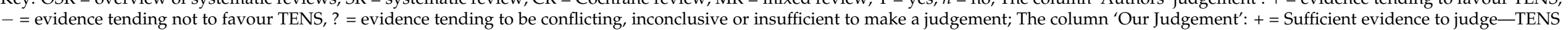
beneficial; - = Sufficient evidence to judge-TENS not beneficial; + / - = Sufficient evidence to judge-inconclusive; ? = Insufficient evidence to judge. 
Table 16. Summary of reviews that include evaluation of TENS for spinal cord injury. The column 'Authors' Conclusion' contains statements taken from reports.

\begin{tabular}{|c|c|c|c|c|c|c|c|c|c|c|}
\hline Ref. & Title & Condition & $\begin{array}{l}\text { Acute/Chronic } \\
\text { Pain }\end{array}$ & $\begin{array}{l}\text { Review } \\
\text { Type }\end{array}$ & $\begin{array}{l}\text { Number } \\
\text { of TENS } \\
\text { Studies }\end{array}$ & $\begin{array}{l}\text { Meta- } \\
\text { Analysis }\end{array}$ & Authors' Conclusion & $\begin{array}{c}\text { Authors' } \\
\text { Judgement }\end{array}$ & $\begin{array}{c}\text { Our } \\
\text { Judgement }\end{array}$ & Comment \\
\hline $\begin{array}{l}\text { Harvey et al. } \\
\text { [172] }\end{array}$ & $\begin{array}{l}\text { The effectiveness of } \\
22 \text { commonly } \\
\text { administered } \\
\text { physiotherapy } \\
\text { interventions for people } \\
\text { with spinal cord injury: } \\
\text { a systematic review }\end{array}$ & $\begin{array}{l}\text { Spinal cord } \\
\text { injury }\end{array}$ & Chronic & SR & 2 & $\mathrm{Y}$ & $\begin{array}{l}\text {.. four interventions were } \\
\text { clearly effective: fitness, } \\
\text { hand and wheelchair } \\
\text { training as well as TENS; } \\
\text { however, the strength of } \\
\text { evidence was not high }\end{array}$ & + & $?$ & \\
\hline $\begin{array}{l}\text { Boldt et al. } \\
\text { [173] }\end{array}$ & $\begin{array}{l}\text { Non-pharmacological } \\
\text { interventions for } \\
\text { chronic pain in people } \\
\text { with spinal cord injury }\end{array}$ & $\begin{array}{l}\text { Spinal cord } \\
\text { injury- } \\
\text { chronic }\end{array}$ & Chronic & $\mathrm{CR}$ & 1 & $\mathrm{~N}$ & $\begin{array}{c}\ldots \text { Insufficient evidence } \\
\ldots \text { Trials using ... TENS } \\
\ldots \text { provided no evidence } \\
\text { that these interventions } \\
\text { reduce chronic pain. }\end{array}$ & $?$ & $?$ & \\
\hline $\begin{array}{l}\text { Mehta et al. } \\
\text { [187] }\end{array}$ & $\begin{array}{c}\text { Neuropathic Pain Post } \\
\text { Spinal Cord Injury Part } \\
\text { 1: Systematic Review of } \\
\text { Physical and Behavioral } \\
\text { Treatment }\end{array}$ & $\begin{array}{l}\text { Spinal cord } \\
\text { injury- } \\
\text { neuropathic } \\
\text { pain }\end{array}$ & Chronic & SR & 2 & $\mathrm{~N}$ & $\begin{array}{l}\text {... there is conflicting } \\
\text { evidence that TENS } \\
\text { treatment reduces } \\
\text { neuropathic pain post } \\
\text { spinal cord injury }\end{array}$ & $?$ & $?$ & \\
\hline $\begin{array}{l}\text { Fattal et al. } \\
\quad[188]\end{array}$ & $\begin{array}{l}\text { What is the efficacy of } \\
\text { physical therapeutics } \\
\text { for treating neuropathic } \\
\text { pain in spinal cord } \\
\text { injury patients? }\end{array}$ & $\begin{array}{l}\text { Spinal cord } \\
\text { injury- } \\
\text { neuropathic }\end{array}$ & Unclear & SR & 2 & $\mathrm{~N}$ & $\begin{array}{l}\text { No statement of conclusion } \\
\text { for TENS }\end{array}$ & $?$ & $?$ & \\
\hline
\end{tabular}

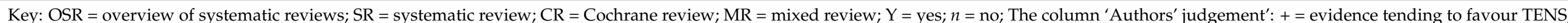

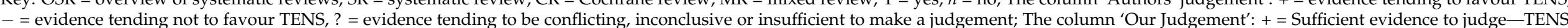
beneficial; - = Sufficient evidence to judge-TENS not beneficial; +/ - = Sufficient evidence to judge—inconclusive; ? = Insufficient evidence to judge. 


\subsection{Procedural Pain (Four Reviews)}

There were four reviews and we judged them all to have insufficient evidence (Table 17). Cochrane reviews evaluating TENS for oocyte retrieval [189], pain during orthodontic treatment and amniocentesis or chorionic villus sampling [190] failed to find any studies. A review on TENS for discomfort during shockwave lithotripsy [191] included only one study.

\subsection{Neuropathic Pain (Three Reviews)}

There were three reviews on neuropathic pain in adults and we judged them all to have insufficient evidence (Table 18). In 2007, the European Federation of Neurological Societies (EFNS) published guidelines on neurostimulation therapy for neuropathic pain based on a systematic evaluation of nine studies on TENS and claimed that high-frequency TENS may be better than placebo and worse than electroacupuncture [20]. Interestingly, TENS was not in scope when the EFNS updated these guidelines in 2016 [21]. The most robust review to date was published in 2017 by Gibson et al. [13] that evaluated TENS for neuropathic pain in adults with a descriptive analysis of 15 studies that was inconclusive.

Undertaking reviews based on symptomology rather than medical diagnoses can challenging. For example, studies of painful conditions traditionally considered as nociceptive (non-neuropathic) may include participants with neuropathic pain elements, yet search strategies used in systematic reviews tend to exclude such conditions. Furthermore, studies of conditions traditionally considered as neuropathic, which are included in reviews on neuropathic pain, may include participants who do not present with neuropathic pain and therefore reviewers need to ensure that eligibility criteria take account of this, perhaps by including criteria that all participants exceeded a threshold for the presence of symptoms of neuropathic pain through screening.

\subsection{Multiple Sclerosis (Three Reviews)}

There were three reviews and we judged them all to have insufficient evidence (Table 19). However, multiple sclerosis presents with a variety of painful symptoms resulting from multiple causes.

Amatya et al. [192] evaluated TENS for low back pain whereas Sawant et al. [79] and Jawahar et al. [193] evaluated TENS on central neuropathic pain associated with abnormal sensibility.

The Cochrane review by Amatya et al. [192] published in 2018 on non-pharmacological interventions for chronic pain in multiple sclerosis, included one study evaluating TENS for low back pain [37] that was judged to be very low-level evidence of benefit. Sawant et al. [79] published a systematic review and meta-analysis in 2015 that included four studies and claimed to provide Grade 2 level evidence that TENS was beneficial and safe for central pain. Interestingly, Sawant et al. [79] included three small pilot studies from the same investigating team evaluating TENS for low back pain $[37,194,195]$, raising issues about violating unit of analysis criteria. 
Table 17. Summary of reviews that include evaluation of TENS for procedural pain. The column 'Authors' Conclusion' contains statements taken from reports.

\begin{tabular}{|c|c|c|c|c|c|c|c|c|c|c|}
\hline Ref. & Title & Condition & $\begin{array}{l}\text { Acute/Chronic } \\
\text { Pain }\end{array}$ & $\begin{array}{l}\text { Review } \\
\text { Type }\end{array}$ & $\begin{array}{c}\text { Number } \\
\text { of TENS } \\
\text { Studies }\end{array}$ & $\begin{array}{l}\text { Meta- } \\
\text { Analysis }\end{array}$ & Authors' Conclusion & $\begin{array}{c}\text { Authors' } \\
\text { Judgement }\end{array}$ & $\begin{array}{c}\text { Our } \\
\text { Judgement }\end{array}$ & Comment \\
\hline $\begin{array}{l}\text { Kwan et al. } \\
\text { [189] }\end{array}$ & $\begin{array}{l}\text { Pain relief for women } \\
\text { undergoing oocyte } \\
\text { retrieval for assisted } \\
\text { reproduction. }\end{array}$ & $\begin{array}{l}\text { Procedural } \\
\text { pain }\end{array}$ & Acute & $\mathrm{CR}$ & 0 & $\mathrm{~N}$ & $\begin{array}{c}\text { No statement of conclusion } \\
\text { for TENS }\end{array}$ & $?$ & $?$ & $\begin{array}{c}\text { Update of } \\
\text { Kwan et al. } \\
\text { [196] }\end{array}$ \\
\hline $\begin{array}{l}\text { Fleming } \\
\text { et al. [197] }\end{array}$ & $\begin{array}{l}\text { Non-pharmacological } \\
\text { interventions for } \\
\text { alleviating pain during } \\
\text { orthodontic treatment }\end{array}$ & $\begin{array}{c}\text { Orthodontic } \\
\text { treatment- } \\
\text { pain }\end{array}$ & Both & $\mathrm{CR}$ & 0 & $\mathrm{~N}$ & $\begin{array}{c}\text { No statement of conclusion } \\
\text { for TENS }\end{array}$ & $?$ & $?$ & \\
\hline $\begin{array}{l}\text { Ngee-Ming } \\
\text { et al. [191] }\end{array}$ & $\begin{array}{l}\text { Complementary } \\
\text { approaches to } \\
\text { decreasing discomfort } \\
\text { during shockwave } \\
\text { lithotripsy (SWL) }\end{array}$ & $\begin{array}{l}\text { Procedural } \\
\text { pain }\end{array}$ & Acute & SR & 1 & $\mathrm{~N}$ & $\begin{array}{c}\text {... methods such as } \\
\text { acupuncture, TENS and } \\
\text { music offer an avenue to } \\
\text { these benefits }\end{array}$ & + & $?$ & \\
\hline $\begin{array}{l}\text { Mujezinovic } \\
\text { et al. [190] }\end{array}$ & $\begin{array}{l}\text { Analgesia for } \\
\text { amniocentesis or } \\
\text { chorionic villus } \\
\text { sampling }\end{array}$ & $\begin{array}{l}\text { Procedural } \\
\text { pain }\end{array}$ & Acute & $\mathrm{CR}$ & 0 & $\mathrm{~N}$ & $\begin{array}{c}\text { No statement of conclusion } \\
\text { for TENS }\end{array}$ & $?$ & $?$ & \\
\hline
\end{tabular}

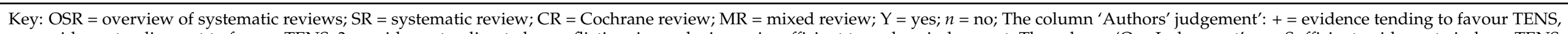

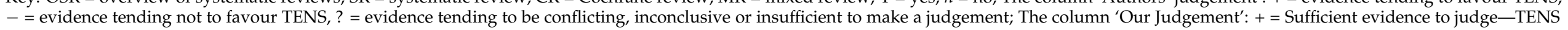
beneficial; - = Sufficient evidence to judge-TENS not beneficial; + / - = Sufficient evidence to judge-inconclusive; ? = Insufficient evidence to judge. 
Table 18. Summary of reviews that include evaluation of TENS for neuropathic pain. The column 'Authors' Conclusion' contains statements taken from reports.

\begin{tabular}{|c|c|c|c|c|c|c|c|c|c|c|}
\hline Ref. & Title & Condition & $\begin{array}{c}\text { Acute/Chronic } \\
\text { Pain }\end{array}$ & $\begin{array}{c}\text { Review } \\
\text { Type }\end{array}$ & $\begin{array}{c}\text { Number } \\
\text { of TENS } \\
\text { Studies }\end{array}$ & $\begin{array}{l}\text { Meta- } \\
\text { Analysis }\end{array}$ & Authors' Conclusion & $\begin{array}{c}\text { Authors' } \\
\text { Judgement }\end{array}$ & $\begin{array}{c}\text { Our } \\
\text { Judgement }\end{array}$ & Comment \\
\hline $\begin{array}{c}\text { Gibson et al. } \\
{[13]}\end{array}$ & $\begin{array}{l}\text { Transcutaneous } \\
\text { electrical nerve } \\
\text { stimulation (TENS) for } \\
\text { neuropathic pain in } \\
\text { adults (Review) }\end{array}$ & $\begin{array}{l}\text { Neuropathic } \\
\text { pain-various }\end{array}$ & Chronic & CR & 15 & $\mathrm{Y}$ & $\begin{array}{l}\text {... we were unable to } \\
\text { confidently state whether } \\
\text { TENS is effective for pain } \\
\text { control in people with } \\
\text { neuropathic pain. The very } \\
\text { low quality of evidence } \\
\text { means we have very } \\
\text { limited confidence in the } \\
\text { effect estimate reported; the } \\
\text { true effect is likely to be } \\
\text { substantially different }\end{array}$ & $?$ & $?$ & $\begin{array}{l}\text { Robust } \\
\text { review }\end{array}$ \\
\hline $\begin{array}{l}\text { Pittler et al. } \\
\text { [198] }\end{array}$ & $\begin{array}{l}\text { Complementary } \\
\text { therapies for } \\
\text { neuropathic and } \\
\text { neuralgic pain: } \\
\text { systematic review }\end{array}$ & $\begin{array}{l}\text { Neuropathic } \\
\text { pain-various }\end{array}$ & UC & SR & 3 & $\mathrm{~N}$ & $\begin{array}{c}\text {... evidence can be } \\
\text { classified as encouraging } \\
\text { and warrants further study } \\
\text { for ... electrostimulation }\end{array}$ & $?$ & $?$ & $\begin{array}{c}\text { Included } \\
\text { transcuta- } \\
\text { neous or } \\
\text { percuta- } \\
\text { neous } \\
\text { electrical } \\
\text { nerve } \\
\text { stimulation }\end{array}$ \\
\hline $\begin{array}{c}\text { Cruccu et al. } \\
\text { [20] }\end{array}$ & $\begin{array}{l}\text { EFNS guidelines on } \\
\text { neurostimulation } \\
\text { therapy for neuropathic } \\
\text { pain }\end{array}$ & $\begin{array}{l}\text { Neuropathic } \\
\text { pain-various }\end{array}$ & UC & SR & 9 & $\mathrm{~N}$ & $\begin{array}{c}\text { High-frequency TENS may } \\
\text { be better than placebo } \\
\text { (level C) although worse } \\
\text { than electroacupuncture } \\
\text { (level B) }\end{array}$ & + & $?$ & \\
\hline
\end{tabular}

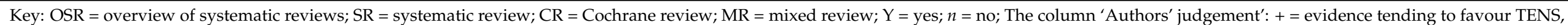

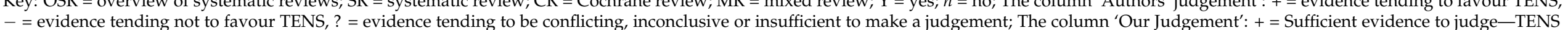
beneficial; - = Sufficient evidence to judge-TENS not beneficial; +/ - = Sufficient evidence to judge—inconclusive; ? = Insufficient evidence to judge. 
Table 19. Summary of reviews that include evaluation of TENS for multiple sclerosis. The column 'Authors' Conclusion' contains statements taken from reports.

\begin{tabular}{|c|c|c|c|c|c|c|c|c|c|c|}
\hline Ref. & Title & Condition & $\begin{array}{l}\text { Acute/Chronic } \\
\text { Pain }\end{array}$ & $\begin{array}{l}\text { Review } \\
\text { Type }\end{array}$ & $\begin{array}{l}\text { Number } \\
\text { of TENS } \\
\text { Studies }\end{array}$ & MA & Authors' Conclusion & $\begin{array}{c}\text { Authors' } \\
\text { Judgement }\end{array}$ & $\begin{array}{c}\text { Our } \\
\text { Judgement }\end{array}$ & Comment \\
\hline $\begin{array}{c}\text { Amatya et al. } \\
\text { [192] }\end{array}$ & $\begin{array}{l}\text { Non-pharmacological } \\
\text { interventions for chronic } \\
\text { pain in multiple sclerosis }\end{array}$ & $\begin{array}{l}\text { Multiple } \\
\text { sclerosis- } \\
\text { chronic } \\
\text { pain }\end{array}$ & Chronic & $\mathrm{CR}$ & 2 & $\mathrm{~N}$ & $\begin{array}{l}\text { There is very low-level } \\
\text { evidence for the use of } \\
\text { non-pharmacological } \\
\text { interventions for chronic pain } \\
\text { such as TENS, ... in pain } \\
\text { intensity of persons with } \\
\text { multiple sclerosis }\end{array}$ & $?$ & $?$ & $\begin{array}{l}\text { Update of } \\
\text { Amatya } \\
\text { et al. [199] }\end{array}$ \\
\hline $\begin{array}{c}\text { Sawant et al. } \\
\text { [79] }\end{array}$ & $\begin{array}{l}\text { Systematic review of } \\
\text { efficacy of TENS for } \\
\text { management of central } \\
\text { pain in people with } \\
\text { multiple sclerosis }\end{array}$ & $\begin{array}{l}\text { Multiple } \\
\text { sclerosis- } \\
\text { central } \\
\text { pain }\end{array}$ & Chronic & SR & 4 & $\mathrm{Y}$ & $\begin{array}{l}\text { TENS is a safe and effective } \\
\text { non-pharmacological } \\
\text { alternative in the management } \\
\text { of central pain in people living } \\
\text { with multiple sclerosis. These } \\
\text { findings are consistent with } \\
\text { GRADE } 2 \text { level of evidence }\end{array}$ & + & $?$ & \\
\hline $\begin{array}{c}\text { Jawahar et al. } \\
\text { [193] }\end{array}$ & $\begin{array}{l}\text { Central neuropathic pain } \\
\text { in multiple sclerosis }\end{array}$ & $\begin{array}{l}\text { Multiple } \\
\text { sclerosis- } \\
\text { neuropathic } \\
\text { pain }\end{array}$ & Chronic & SR & 2 & $\mathrm{~N}$ & $\begin{array}{l}\text { TENS may be effective in } \\
\text { reducing central neuropathic } \\
\text { pain ... }\end{array}$ & + & $?$ & \\
\hline
\end{tabular}

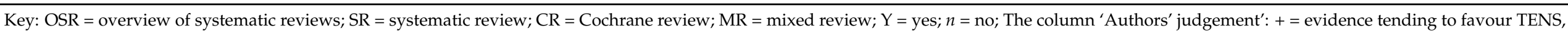

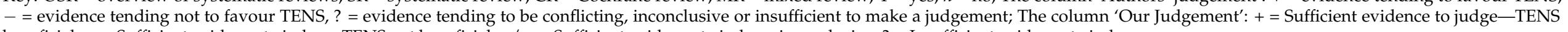
beneficial; $-=$ Sufficient evidence to judge-TENS not beneficial; + / - = Sufficient evidence to judge-inconclusive; ? = Insufficient evidence to judge. 


\subsection{Painful Spasticity (Three Reviews)}

There were three reviews and we judged them all to have insufficient evidence (Table 20). In 2016, Mills and Dossa [200] published a systematic review and descriptive analysis of 14 studies that they claimed provided level 1 and 2 evidence that TENS improves spasticity-related outcomes, especially when TENS was used in combination with exercise and task-related training. In 2019, Fernandez-Tenorio et al. [201] published a systematic review of 10 studies that provided evidence that TENS may be beneficial for painful spasticity. A Cochrane review evaluating TENS for spasticity following traumatic brain injury was inconclusive [202].

\subsection{Post-Amputation Pain (Three Reviews)}

There were three reviews we judged them all to have insufficient evidence (Table 21). A Cochrane review published in 2015 by Johnson et al. [203] found no RCTs and only two small non RCT studies, and two non-Cochrane systematic reviews included only three small studies.

\subsection{Conditions with Two Reviews}

We found two reviews for each of the following conditions and we judged them all to have insufficient evidence: rheumatoid arthritis, headache or migraine, carpal tunnel syndrome, and fracture pain (Table 22).

We were surprised at how few reviews had been conducted on TENS for rheumatoid arthritis and that they were published nearly two decades ago; one review claimed evidence supported beneficial effects [204] and a Cochrane review was inconclusive [205]. Interestingly, NICE guidelines recommend that patients have access to specialist physiotherapy to learn about the short-term pain relief provided by methods such as TENS [206]. A systematic review of four studies on TENS for the treatment of migraine published in 2018 by Tao et al. [207] included a meta-analysis that was claimed to provide low quality evidence that TENS may be beneficial and well-tolerated treatment for migraine.

\subsection{Conditions with One Review}

We found one review for a variety of painful conditions (Table 23), and we judged them all to have insufficient evidence of benefit. Of note was a systematic review on physiotherapy for pain and disability in adults with complex regional pain syndrome (CRPS) types I and II that included six studies on TENS, although reviewers concluded that evidence was absent or unclear [208]. 
Table 20. Summary of reviews that include evaluation of TENS for painful spasticity. The column 'Authors' Conclusion' contains statements taken from reports.

\begin{tabular}{|c|c|c|c|c|c|c|c|c|c|c|}
\hline Ref. & Title & Condition & $\begin{array}{l}\text { Acute/Chronic } \\
\text { Pain }\end{array}$ & $\begin{array}{l}\text { Review } \\
\text { Type }\end{array}$ & $\begin{array}{l}\text { Number } \\
\text { of TENS } \\
\text { Studies }\end{array}$ & MA & Authors' Conclusion & $\begin{array}{c}\text { Authors' } \\
\text { Judgement }\end{array}$ & $\begin{array}{l}\text { Our } \\
\text { Judgement }\end{array}$ & Comment \\
\hline $\begin{array}{l}\text { Fernandez- } \\
\text { Tenorio et al. } \\
\text { [201] }\end{array}$ & $\begin{array}{l}\text { Transcutaneous electrical } \\
\text { nerve stimulation for } \\
\text { spasticity: A systematic } \\
\text { review }\end{array}$ & $\begin{array}{l}\text { Spasticity- } \\
\text { painful }\end{array}$ & Both & SR & 10 & $\mathrm{~N}$ & $\begin{array}{l}\text { We recommend TENS as a } \\
\text { treatment for spasticity due to } \\
\text { its low cost, ease of use, and } \\
\text { absence of adverse reactions }\end{array}$ & + & $?$ & \\
\hline $\begin{array}{l}\text { Synnot et al. } \\
\text { [202] }\end{array}$ & $\begin{array}{c}\text { Interventions for } \\
\text { managing skeletal muscle } \\
\text { spasticity following } \\
\text { traumatic brain injury } \\
\text { (Review) }\end{array}$ & $\begin{array}{l}\text { Muscle } \\
\text { spasticity- } \\
\text { traumatic } \\
\text { brain injury }\end{array}$ & Acute & CR & 1 & $\mathrm{~N}$ & $\begin{array}{c}\text { No statement of conclusion for } \\
\text { TENS }\end{array}$ & $?$ & $?$ & \\
\hline $\begin{array}{l}\text { Mills et al. } \\
\text { [200] }\end{array}$ & $\begin{array}{l}\text { Transcutaneous Electrical } \\
\text { Nerve Stimulation for } \\
\text { Management of Limb } \\
\text { Spasticity: A Systematic } \\
\text { Review }\end{array}$ & Spasticity & Both & SR & 14 & $\mathrm{~N}$ & $\begin{array}{c}\text { There was level } 1 \text { and } 2 \\
\text { evidence for TENS improving } \\
\text { spasticity-related outcome } \\
\text { measures ... Better responses } \\
\text { in outcome measures ... when } \\
\text { TENS was used in combination } \\
\text { with active therapy (e.g., } \\
\text { exercise and task-related } \\
\text { training) }\end{array}$ & + & $?$ & \\
\hline
\end{tabular}

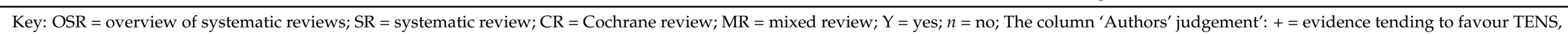

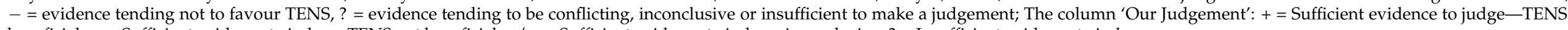
beneficial; - = Sufficient evidence to judge-TENS not beneficial; +/ - = Sufficient evidence to judge—inconclusive; ? = Insufficient evidence to judge. 
Table 21. Summary of reviews that include evaluation of TENS for post amputation pain. The column 'Authors' Conclusion' contains statements taken from reports.

\begin{tabular}{|c|c|c|c|c|c|c|c|c|c|c|}
\hline Ref. & Title & Condition & $\begin{array}{l}\text { Acute/Chronic } \\
\text { Pain }\end{array}$ & $\begin{array}{l}\text { Review } \\
\text { Type }\end{array}$ & $\begin{array}{l}\text { Number } \\
\text { of TENS } \\
\text { Studies }\end{array}$ & MA & Authors' Conclusion & $\begin{array}{c}\text { Authors' } \\
\text { Judgement }\end{array}$ & $\begin{array}{c}\text { Our } \\
\text { Judgement }\end{array}$ & Comment \\
\hline $\begin{array}{l}\text { Johnson et al. } \\
\text { [203] }\end{array}$ & $\begin{array}{c}\text { Transcutaneous electrical } \\
\text { nerve stimulation (TENS) } \\
\text { for phantom pain and } \\
\text { stump pain following } \\
\text { amputation in adults } \\
\text { (Review) }\end{array}$ & $\begin{array}{l}\text { Amputation- } \\
\text { phantom and } \\
\text { stump pain }\end{array}$ & Chronic & $\mathrm{CR}$ & 2 & $\mathrm{~N}$ & $\begin{array}{l}\text { There were no RCTs to judge } \\
\text { the effectiveness of TENS for } \\
\text { the management of phantom } \\
\text { pain and stump pain }\end{array}$ & $?$ & $?$ & $\begin{array}{l}\text { There were } \\
\text { two non } \\
\text { RCTs }\end{array}$ \\
\hline Hu et al. [209] & $\begin{array}{l}\text { The effectiveness of } \\
\text { acupuncture/TENS for } \\
\text { phantom limb syndrome: } \\
\text { A systematic review of } \\
\text { controlled clinical trials }\end{array}$ & $\begin{array}{l}\text { Amputation- } \\
\text { phantom } \\
\text { pain }\end{array}$ & Chronic & SR & 3 & $\mathrm{~N}$ & $\begin{array}{c}\text { There is some evidence for the } \\
\text { use of acupuncture and TENS } \\
\text { for the treatment of phantom } \\
\text { limb pain, but insufficient } \\
\text { high-quality evidence is } \\
\text { available }\end{array}$ & $?$ & $?$ & \\
\hline $\begin{array}{l}\text { Halbert et al. } \\
\text { [210] }\end{array}$ & $\begin{array}{l}\text { Evidence for the Optimal } \\
\text { Management of Acute } \\
\text { and Chronic Phantom } \\
\text { Pain: A Systematic } \\
\text { Review }\end{array}$ & $\begin{array}{l}\text { Amputation- } \\
\text { phantom } \\
\text { pain }\end{array}$ & Chronic & SR & 3 & $\mathrm{~N}$ & $\begin{array}{c}\text { No statement of conclusion for } \\
\text { TENS }\end{array}$ & $?$ & $?$ & \\
\hline
\end{tabular}

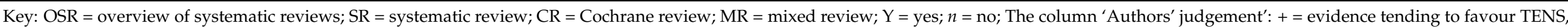

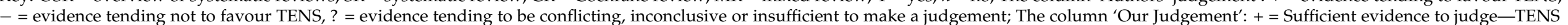
beneficial; - = Sufficient evidence to judge-TENS not beneficial; $+/-=$ Sufficient evidence to judge-inconclusive; ? = Insufficient evidence to judge. 


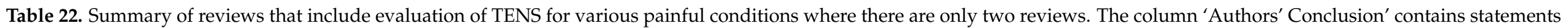
taken from reports.

\begin{tabular}{|c|c|c|c|c|c|c|c|c|c|c|}
\hline Ref. & Title & Condition & $\begin{array}{c}\text { Acute/Chronic } \\
\text { Pain }\end{array}$ & $\begin{array}{c}\text { Review } \\
\text { Type }\end{array}$ & $\begin{array}{c}\text { Number } \\
\text { of TENS } \\
\text { Studies }\end{array}$ & MA & Authors' Conclusion & $\begin{array}{c}\text { Authors' } \\
\text { Judgement }\end{array}$ & $\begin{array}{c}\text { Our } \\
\text { Judgement }\end{array}$ & Comment \\
\hline \multicolumn{11}{|c|}{ Rheumatoid Arthritis } \\
\hline $\begin{array}{l}\text { Brosseau et al. } \\
\text { [205] }\end{array}$ & $\begin{array}{l}\text { Transcutaneous electrical } \\
\text { nerve stimulation (TENS) } \\
\text { for the treatment of } \\
\text { rheumatoid arthritis in } \\
\text { the hand (Cochrane } \\
\text { review) }\end{array}$ & $\begin{array}{l}\text { Rheumatoid } \\
\text { arthritis- } \\
\text { hand }\end{array}$ & Chronic & CR & 3 & $\mathrm{~N}$ & $\begin{array}{l}\text { There are conflicting effects of } \\
\text { TENS on pain outcomes in } \\
\text { patients with RA. AL-TENS is } \\
\text { beneficial for reducing pain } \\
\text { intensity and improving } \\
\text { muscle power scores over } \\
\text { placebo while, conversely, } \\
\text { C-TENS resulted in no clinical } \\
\text { benefit on pain intensity } \\
\text { compared with placebo. } \\
\text { However, C-TENS resulted in a } \\
\text { clinical benefit on patient } \\
\text { assessment of change in } \\
\text { disease over AL-TENS }\end{array}$ & $?$ & $?$ & $\begin{array}{c}\text { Journal } \\
\text { version } \\
\text { also } \\
\text { available } \\
\text { in } \\
\text { Brosseau } \\
\text { et al. [62] }\end{array}$ \\
\hline
\end{tabular}


Table 22. Cont.

\begin{tabular}{|c|c|c|c|c|c|c|c|c|c|c|}
\hline Ref. & Title & Condition & $\begin{array}{c}\text { Acute/Chronic } \\
\text { Pain }\end{array}$ & $\begin{array}{l}\text { Review } \\
\text { Type }\end{array}$ & $\begin{array}{l}\text { Number } \\
\text { of TENS } \\
\text { Studies }\end{array}$ & MA & Authors' Conclusion & $\begin{array}{c}\text { Authors' } \\
\text { Judgement }\end{array}$ & $\begin{array}{c}\text { Our } \\
\text { Judgement }\end{array}$ & Comment \\
\hline \multicolumn{11}{|c|}{ Headache or migraine } \\
\hline Tao et al. [207] & $\begin{array}{l}\text { Effectiveness of } \\
\text { transcutaneous electrical } \\
\text { nerve stimulation for the } \\
\text { treatment of migraine: a } \\
\text { meta-analysis of } \\
\text { randomized controlled } \\
\text { trials }\end{array}$ & Migraine & Chronic & SR & 4 & $\mathrm{Y}$ & $\begin{array}{l}\text { This meta-analysis suggests } \\
\text { that TENS may serve as an } \\
\text { effective and well-tolerated } \\
\text { alternative for migraineurs. } \\
\text { However, low quality of } \\
\text { evidence prevents us from } \\
\text { reaching definitive conclusions } \\
\text { RCTs }\end{array}$ & + & $?$ & $\begin{array}{l}\text { Some inter- } \\
\text { ventions } \\
\text { not } \\
\text { standard } \\
\text { TENS }\end{array}$ \\
\hline $\begin{array}{c}\text { Bronfort et al. } \\
\text { [211] }\end{array}$ & $\begin{array}{l}\text { Non-invasive physical } \\
\text { treatments for } \\
\text { chronic/recurrent } \\
\text { headache }\end{array}$ & Headache & Chronic & $\mathrm{CR}$ & 2 & $\mathrm{~N}$ & $\begin{array}{l}\text { There is preliminary evidence } \\
\text { that a combination of TENS } \\
\text { and electrical neurotransmitter } \\
\text { modulation is inferior to } \\
\text { biofeedback and superior to } \\
\text { relaxation for reduction of } \\
\text { headache pain ... evidence } \\
\text { from one trial). There is limited } \\
\text { evidence that a regimen of } \\
\text { auto-massage, TENS, and } \\
\text { stretching is superior to } \\
\text { acupuncture for pain relief } 4 \text { to } \\
9 \text { weeks post-treatment. } \\
\text { (evidence from one trial). }\end{array}$ & $?$ & $?$ & \\
\hline
\end{tabular}


Table 22. Cont.

\begin{tabular}{|c|c|c|c|c|c|c|c|c|c|c|}
\hline Ref. & Title & Condition & $\begin{array}{l}\text { Acute/Chronic } \\
\text { Pain }\end{array}$ & $\begin{array}{l}\text { Review } \\
\text { Type }\end{array}$ & $\begin{array}{l}\text { Number } \\
\text { of TENS } \\
\text { Studies }\end{array}$ & MA & Authors' Conclusion & $\begin{array}{c}\text { Authors' } \\
\text { Judgement }\end{array}$ & $\begin{array}{c}\text { Our } \\
\text { Judgement }\end{array}$ & Comment \\
\hline \multicolumn{11}{|c|}{ Carpal tunnel syndrome } \\
\hline $\begin{array}{l}\text { Huisstede } \\
\text { et al. [212] }\end{array}$ & $\begin{array}{c}\text { Carpal Tunnel Syndrome: } \\
\text { Effectiveness of Physical } \\
\text { Therapy and } \\
\text { Electrophysical } \\
\text { Modalities. An Updated } \\
\text { Systematic Review of } \\
\text { Randomized Controlled } \\
\text { Trials }\end{array}$ & Carpal Tunnel & Chronic & SR & 2 & $\mathrm{~N}$ & $\begin{array}{l}\ldots \text { there is moderate evidence } \\
\text { that interferential current } \\
\text { therapy is more effective than a } \\
\text { night splint or TENS in the } \\
\text { short term }\end{array}$ & - & $?$ & \\
\hline $\begin{array}{l}\text { Peters et al. } \\
\text { [213] }\end{array}$ & $\begin{array}{l}\text { Rehabilitation following } \\
\text { carpal tunnel release }\end{array}$ & Carpal tunnel & Unclear & $\mathrm{CR}$ & 0 & $\mathrm{~N}$ & $\begin{array}{c}\text { No statement of conclusion for } \\
\text { TENS }\end{array}$ & $?$ & $?$ & \\
\hline \multicolumn{11}{|c|}{ Fracture Pain } \\
\hline $\begin{array}{l}\text { Perillo et al. } \\
\text { [214] }\end{array}$ & $\begin{array}{l}\text { Pre-hospital femoral neck } \\
\text { fracture management: A } \\
\text { review of the literature }\end{array}$ & Bone fracture & Acute & SR & 1 & $\mathrm{~N}$ & $\begin{array}{c}\text { No statement of conclusion for } \\
\text { TENS }\end{array}$ & $?$ & $?$ & $\begin{array}{l}\text { One study } \\
\text { found } \\
\text { TENS } \\
\text { effective in } \\
\text { treating } \\
\text { pain in the } \\
\text { prehospi- } \\
\text { tal } \\
\text { environ- } \\
\text { ment }\end{array}$ \\
\hline $\begin{array}{l}\text { Abou-Setta } \\
\text { et al. [90] }\end{array}$ & $\begin{array}{c}\text { Comparative } \\
\text { Effectiveness of Pain } \\
\text { Management } \\
\text { Interventions for Hip } \\
\text { Fracture: A Systematic } \\
\text { Review }\end{array}$ & Hip fracture & Acute & SR & 2 & $\mathrm{Y}$ & $\begin{array}{l}\text {.. based on limited evidence, } \\
\text { [TENS] seem to be safe and } \\
\text { may result in clinically } \\
\text { meaningful reductions in pain }\end{array}$ & $?$ & $?$ & \\
\hline
\end{tabular}

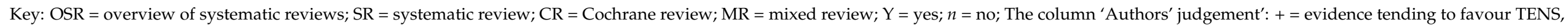

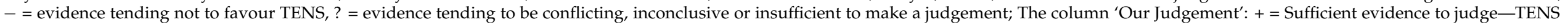
beneficial; - = Sufficient evidence to judge-TENS not beneficial; + / - = Sufficient evidence to judge - inconclusive; $?=$ Insufficient evidence to judge 


\subsection{Outcomes for Adverse Events}

Generally, systematic reviews did not pre-specify a protocol to evaluate adverse events. Those that did (e.g., all Cochrane reviews) found that most studies captured adverse events spontaneously (ad hoc) and did not have pre-specified protocols for gathering nor analysing adverse events and/or the safety of using TENS. There were no serious adverse events reported in the included reviews, and adverse events that were reported were infrequent and of minimal severity, such as mild skin irritation or discomfort from electrical currents. We judged that evidence was inconclusive for harm, but tending toward TENS being safe, with negligible adverse events.

\subsection{Synopsis of Characteristics and Outcomes}

A synopsis of the analyses of characteristics and outcomes of included reviews is summarised in Table 24. In summary, the methodological quality of many reviews is good, especially those conducted by the Cochrane Collaboration, but unfortunately these reviews reveal a paucity of studies, and/or studies that have insufficient samples sizes, high risk of bias, and/or are poorly communicated. The majority of meta-analyses did not meet our threshold for sufficient pooled data points to have confidence in the precision of effect size estimates. There was much variability in meta-analytical procedures for pain intensity including; the type of estimate reported e.g., SMD, MD, RR; the timepoint used e.g., during or post TENS; whether the estimate was absolute or relative to baseline; and whether fixed or random effects models were employed. There was evidence of violation of unit of analyses principles including estimates that had double counted study data. There were instances of a paucity of systematic reviews for common painful conditions e.g., rheumatoid arthritis, and instances of persistent publication of systematic reviews despite a paucity of primary studies e.g., non-specific low back pain. 


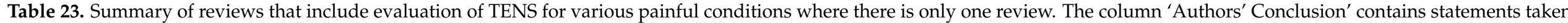
from reports.

\begin{tabular}{|c|c|c|c|c|c|c|c|c|c|c|}
\hline Ref. & Title & Condition & $\begin{array}{l}\text { Acute/Chronic } \\
\text { Pain }\end{array}$ & $\begin{array}{l}\text { Review } \\
\text { Type }\end{array}$ & $\begin{array}{l}\text { Number } \\
\text { of TENS } \\
\text { Studies }\end{array}$ & MA & Authors' Conclusion & $\begin{array}{c}\text { Authors' } \\
\text { Judgement }\end{array}$ & $\begin{array}{l}\text { Our } \\
\text { Judgement }\end{array}$ & Comment \\
\hline $\begin{array}{l}\text { Deussen et al. } \\
\text { [215] }\end{array}$ & $\begin{array}{l}\text { Relief of pain due to uterine } \\
\text { cramping/involution after } \\
\text { birth }\end{array}$ & $\begin{array}{l}\text { Uterine cramp- } \\
\text { ing/involution } \\
\text { after birth }\end{array}$ & Acute & $\mathrm{CR}$ & 3 & $\mathrm{~N}$ & $\begin{array}{l}\text { Very low-certainty evidence means } \\
\text { we are uncertain if TENS is better } \\
\text { than no TENS for adequate pain } \\
\text { relief as reported by the women }\end{array}$ & $?$ & $?$ & $\begin{array}{l}\text { Update of } \\
\text { Deussen } \\
\text { et al. [216] }\end{array}$ \\
\hline Pal et al. [217] & $\begin{array}{l}\text { Transcutaneous electrical } \\
\text { nerve stimulation (TENS) for } \\
\text { pain management in sickle } \\
\text { cell disease (Review) }\end{array}$ & Sickle cell pain & Acute & $\mathrm{CR}$ & 1 & $\mathrm{~N}$ & $\begin{array}{l}\text { Since we have only included one } \\
\text { small and very low-quality trial, } \\
\text { with a high risk of bias across } \\
\text { several domains, we are unable to } \\
\text { conclude whether TENS is harmful } \\
\text { or beneficial for managing pain in } \\
\text { people with sickle cell disease }\end{array}$ & $?$ & $?$ & \\
\hline De Andres et al. & $\begin{array}{l}\text { Vulvodynia-An } \\
\text { Evidence-Based Literature } \\
\text { Review and Proposed } \\
\text { Treatment Algorithm }\end{array}$ & Vulvodynia & Chronic & SR & 3 & $\mathrm{~N}$ & $\begin{array}{l}\text { No statement of conclusion for } \\
\text { TENS }\end{array}$ & $?$ & $?$ & \\
\hline Liao et al. [219] & $\begin{array}{c}\text { Efficacy of Non-invasive } \\
\text { Stellate Ganglion Blockade } \\
\text { Performed Using Physical } \\
\text { Agent Modalities in Patients } \\
\text { with Sympathetic } \\
\text { Hyperactivity-Associated } \\
\text { Disorders: A Systematic } \\
\text { Review and Meta-Analysis. }\end{array}$ & $\begin{array}{l}\text { Sympathetic } \\
\text { Hyperactivity- } \\
\text { Associated } \\
\text { Disorders }\end{array}$ & Unclear & SR & 3 & $\mathrm{~N}$ & $\begin{array}{l}\text { Non-invasive Stellate Ganglion } \\
\text { Blockade performed using PAMs } \\
\text { [including TENS] effectively } \\
\text { relieves pain of various etiologies, } \\
\text { making it a valuable addition to } \\
\text { the contemporary pain } \\
\text { management armamentarium }\end{array}$ & $?$ & $?$ & \\
\hline Oor et al. [220] & $\begin{array}{l}\text { A systematic review of the } \\
\text { treatment for abdominal } \\
\text { cutaneous nerve entrapment } \\
\text { syndrome }\end{array}$ & $\begin{array}{l}\text { Nerve } \\
\text { entrapment } \\
\text { syndrome- } \\
\text { abdominal } \\
\text { cutaneous }\end{array}$ & Chronic & SR & 0 & $\mathrm{~N}$ & $\begin{array}{l}\text { No statement of conclusion for } \\
\text { TENS }\end{array}$ & $?$ & $?$ & \\
\hline $\begin{array}{l}\text { Smart et al. } \\
\text { [208] }\end{array}$ & $\begin{array}{l}\text { Physiotherapy for pain and } \\
\text { disability in adults with } \\
\text { complex regional pain } \\
\text { syndrome (CRPS) types I } \\
\text { and II. }\end{array}$ & $\begin{array}{l}\text { Complex } \\
\text { regional pain } \\
\text { syndrome }\end{array}$ & Both & $\mathrm{CR}$ & 6 & $\mathrm{~N}$ & $\begin{array}{l}\text { Evidence of the effectiveness of } \\
\text { multimodal physiotherapy, } \\
\text { electrotherapy and manual } \\
\text { lymphatic drainage for treating } \\
\text { people with CRPS types I and II is } \\
\text { generally absent or unclear }\end{array}$ & + & $?$ & \\
\hline
\end{tabular}


Table 23. Cont.

\begin{tabular}{|c|c|c|c|c|c|c|c|c|c|c|}
\hline Ref. & Title & Condition & $\begin{array}{c}\text { Acute/Chronic } \\
\text { Pain }\end{array}$ & $\begin{array}{l}\text { Review } \\
\text { Type }\end{array}$ & $\begin{array}{c}\text { Number } \\
\text { of TENS } \\
\text { Studies }\end{array}$ & MA & Authors' Conclusion & $\begin{array}{c}\text { Authors' } \\
\text { Judgement }\end{array}$ & $\begin{array}{c}\text { Our } \\
\text { Judgement }\end{array}$ & Comment \\
\hline $\begin{array}{l}\text { Mansilla et al. } \\
\text { [221] }\end{array}$ & $\begin{array}{l}\text { Efficacy of transcutaneous } \\
\text { electrical stimulation in } \\
\text { trigeminal neuralgia. } \\
\text { Eficacia de la estimulación } \\
\text { eléctrica transcutánea en la } \\
\text { neuralgia del trigémino. } \\
\text { Rehabilitacion, 50, 81-86. }\end{array}$ & $\begin{array}{l}\text { Trigeminal } \\
\text { neuralgia }\end{array}$ & Chronic & SR & 2 & $\mathrm{~N}$ & $\begin{array}{l}\text { On the basis of published studies, } \\
\text { TENS contributes positively to pain } \\
\text { relief and functional improvement } \\
\text { in patients affected by trigeminal } \\
\text { pain. A larger number of studies } \\
\text { are needed to ... recommend its } \\
\text { use }\end{array}$ & + & $?$ & $\begin{array}{c}\text { In } \\
\text { Portuguese }\end{array}$ \\
\hline $\begin{array}{l}\text { Kovacs et al. } \\
\quad[222]\end{array}$ & $\begin{array}{l}\text { Surgery versus conservative } \\
\text { treatment for symptomatic } \\
\text { lumbar spinal stenosis: a } \\
\text { systematic review of } \\
\text { randomized controlled trials. }\end{array}$ & Spinal stenosis & Chronic & SR & 1 & $\mathrm{~N}$ & $\begin{array}{l}\text { One RCT on TENS as a comparator } \\
\text { and uses TENS but is in } \\
\text { combination with ultrasound and } \\
\text { exercise. Not possible to isolate } \\
\text { TENS }\end{array}$ & $?$ & $?$ & \\
\hline $\begin{array}{l}\text { McKneely et al. } \\
\text { [223] }\end{array}$ & $\begin{array}{l}\text { A systematic review of the } \\
\text { effectiveness of physical } \\
\text { therapy interventions for } \\
\text { temporomandibular } \\
\text { disorders. }\end{array}$ & $\begin{array}{l}\text { temporomandibular } \\
\text { disorders }\end{array}$ & Unclear & SR & 2 & $\mathrm{~N}$ & $\begin{array}{c}\text {.. further research is warranted } \\
\text { before dismissing any effect of } \\
\text { TENS }\end{array}$ & $?$ & $?$ & \\
\hline
\end{tabular}

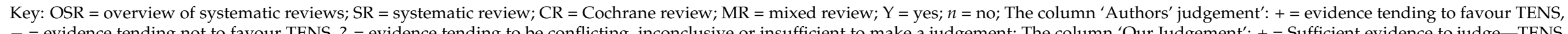

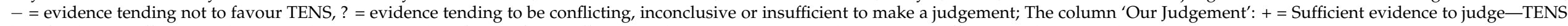
beneficial; $-=$ Sufficient evidence to judge -TENS not beneficial; + / - = Sufficient evidence to judge—inconclusive; $?=$ Insufficient evidence to judge 
Table 24. Synopsis of the analyses of characteristics and outcomes of included reviews.

\begin{tabular}{|c|c|c|c|c|}
\hline Condition & $\begin{array}{c}\text { Quantity of Included } \\
\text { Reviews }\end{array}$ & Comment-Quality of Reviews & Comment-Quantity and Quality of RCT Data & $\begin{array}{c}\text { Judgement-Analgesic } \\
\text { Efficacy }\end{array}$ \\
\hline $\begin{array}{l}\text { Mixtures of painful } \\
\text { conditions }\end{array}$ & 15 & $\begin{array}{l}\text { One OCR, CRs and some SRs of high } \\
\text { methodological quality } \\
\text { Strongest review: Chronic pain-Gibson } \\
\text { et al. [6]; Acute pain-Johnson et al. [83] }\end{array}$ & $\begin{array}{c}\text { Well over } 200 \text { different studies on TENS for any } \\
\text { type of pain cited in the included reviews. Majority } \\
\text { of studies have small (inadequate) sized samples } \\
\text { Strongest RCT: Dailey et al. [224] }\end{array}$ & + \\
\hline $\begin{array}{l}\text { Musculoskeletal pain } \\
\text { including non-specific low } \\
\text { back or neck pain }\end{array}$ & $\begin{array}{l}40 \text { reviews including } 23 \\
\text { reviews on non-specific back } \\
\text { pain }\end{array}$ & $\begin{array}{c}\text { CRs and some SRs are high methodological } \\
\text { quality } \\
\text { Strongest review: Johnson and Martinsson } \\
\text { [10] with Wu et al. [14] and Jauregui et al. } \\
\text { [52] also notable }\end{array}$ & $\begin{array}{c}\text { Some moderately sized studies well designed } \\
\text { studies but most RCTs have small (inadequate) } \\
\text { sample sizes. More reviews than studies for back } \\
\text { and for neck pain } \\
\text { Majority of RCTs have small samples } \\
\text { Strongest RCTs: Warke et al. [37], Deyo et al. [49] }\end{array}$ & ++ \\
\hline Osteoarthritis & 11 reviews & $\begin{array}{l}\text { CRs and some SRs are high methodological } \\
\text { quality } \\
\text { Strongest review: Chen et al. [77] and } \\
\text { Rutjes et al. [78] }\end{array}$ & $\begin{array}{l}\text { Some moderately sized studies well designed } \\
\text { studies but most RCTs have small (inadequate) } \\
\text { sample sizes } \\
\text { Strongest RCT: Atamaz et al. [225] } \\
\text { Palmer et al. [226] }\end{array}$ & + \\
\hline Labour pain & 10 reviews & $\begin{array}{l}\text { CRs and some SRs are high methodological } \\
\text { quality } \\
\text { Strongest reviews: Thuvarakan et al. [26] } \\
\text { and Dowswell et al. [22] }\end{array}$ & $\begin{array}{l}\text { Some moderately sized studies well designed } \\
\text { studies but most RCTs have small (inadequate) } \\
\text { sample sizes } \\
\text { Strongest RCT: Baez-Suarez et al. [228], Tsen et al. } \\
\text { [229], Thomas et al.,1988 [230] }\end{array}$ & + \\
\hline $\begin{array}{l}\text { Dysmenorrhea and Pelvic } \\
\text { pain }\end{array}$ & 12 reviews & $\begin{array}{l}\text { Some SRs are high methodological quality } \\
\text { Strongest review: Cottrell et al. [71] and } \\
\text { Arik et al. [70] }\end{array}$ & $\begin{array}{c}\text { Few moderately sized studies well designed } \\
\text { studies but most RCTs have small (inadequate) } \\
\text { sample sizes } \\
\text { Strongest RCT: Bai et al. [231] }\end{array}$ & + \\
\hline
\end{tabular}


Table 24. Cont.

\begin{tabular}{|c|c|c|c|c|}
\hline Condition & $\begin{array}{l}\text { Quantity of Included } \\
\text { Reviews }\end{array}$ & Comment-Quality of Reviews & Comment-Quantity and Quality of RCT Data & $\begin{array}{l}\text { Judgement-Analgesic } \\
\text { Efficacy }\end{array}$ \\
\hline Fibromyalgia & 6 reviews & $\begin{array}{c}\text { CRs and some SRs are high methodological } \\
\text { quality } \\
\text { Strongest review: Johnson et al. [156] and } \\
\text { Megia Garcia et al. [155] }\end{array}$ & $\begin{array}{l}\text { One very high quality moderately sized study } \\
\text { Strongest RCT: Dailey et al. [224] }\end{array}$ & + \\
\hline Cancer and its treatment & 5 reviews & $\begin{array}{c}\text { CRs and some SRs are high methodological } \\
\text { quality } \\
\text { Strongest review: Hurlow et al. [168] }\end{array}$ & No suitable RCTs & $?$ \\
\hline $\begin{array}{l}\text { Specific shoulder } \\
\text { conditions }\end{array}$ & 5 reviews & $\begin{array}{l}\text { One CR of high methodological quality } \\
\text { Strongest reviews: } \\
\text { Page et al.-_rotator cuff disease [176] }\end{array}$ & $\begin{array}{c}\text { Few studies and most RCTs have small } \\
\text { (inadequate) sample } \\
\text { Strongest RCT: Baskurt et al. [232] }\end{array}$ & + \\
\hline $\begin{array}{l}\text { Peripheral diabetic } \\
\text { neuropathy }\end{array}$ & 5 reviews & $\begin{array}{c}\text { Some SRs are high methodological quality } \\
\text { Strongest review: Zeng et al. [169] and } \\
\text { Stein et al. [65] }\end{array}$ & $\begin{array}{l}\text { Some moderately sized studies well designed } \\
\text { studies but most RCTs have small (inadequate) } \\
\text { sample sizes } \\
\text { Strongest RCT: Bulut et al. [233] }\end{array}$ & + \\
\hline Other painful conditions & 47 reviews & $\begin{array}{c}\text { CRs and some SRs are high methodological } \\
\text { quality } \\
\text { Strongest reviews: } \\
\text { Gibson et al.-neuropathic pain [13], } \\
\text { Fernandez-Tenorio et al.--spasticity [201] }\end{array}$ & $\begin{array}{l}\text { Some moderately sized studies well designed } \\
\text { studies but most RCTs have small (inadequate) } \\
\text { sample sizes } \\
\text { Strongest RCT: Amer-Cuenca et al. } \\
\text { [234]—-procedural pain }\end{array}$ & $?$ \\
\hline Overall & 169 reviews & $\begin{array}{c}\text { CRs and some SRs are high methodological } \\
\text { quality }\end{array}$ & Strongest RCT: Dailey et al. [224] & + \\
\hline
\end{tabular}

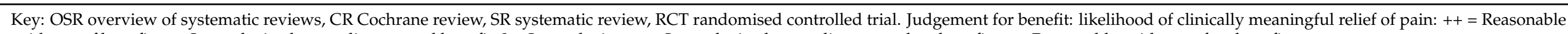

evidence of benefit, + = Inconclusive but tending toward benefit, ? = Inconclusive, $-=$ Inconclusive but tending toward no benefit, -- Reasonable evidence of no benefit. 


\section{Discussion}

Pain mechanisms are complex, resulting in uncertainty in finite diagnoses. Pain acts to protect the integrity of tissue and does not act as a marker of tissue damage, i.e., hurt does not always mean harm. In medicine, great effort is given to identifying input to the brain in the form of 'pain generators' such as nociception (nociceptive pain) or neuropathy (neuropathic pain) and associated sensitisation and bioplasticity (nociplastic pain). However, contemporary neuroscience acknowledges that pain is an output of the brain based on perceptual inference and influenced by a wide variety of biopsychosocial factors. In other words, 'everything matters when it comes to pain', including feelings, activities, stress, sleep, anxiety, unemployment, social situation, and self-identity to name but a few. Pain medicine has been slow to deliver a biopsychosocial model at the point of care, and there is continued uncertainty whether to select treatment according to symptoms or medical diagnosis.

It is acknowledged that physical activity and psychological interventions delivered within a self-management strategy is optimal for pain management. The goal is to improve activities of daily living and quality of life through pain education, lifestyle adjustment and healthy living. Surgery and medication are often not the answer because they can be harmful and efficacy in the long-term is doubtful. Neuromodulation techniques such as TENS are used within this framework to alleviate the sensations of pain, muscle tension and spasm. This provides a variety of indirect benefits including enhanced function, improved psychological well-being, better sleep, and medication reduction. TENS is widely accepted by patients because it is in-expensive, it can be self-administered, and it has few adverse events and minimal toxicity. TENS has the potential to be used for any type of acute or chronic pain, such as post-operative pain, labour pain, neuropathic pain, and non-specific musculoskeletal pain. The ease of use of TENS makes it ideal for a variety of care settings including community care, primary care, secondary care (in-patient and outpatient hospital settings), tertiary care (e.g., hospice settings), workplace settings (for occupational-related pain) and sport-settings (for sports-related pain).

\subsection{Main Findings}

To our knowledge, this is the first comprehensive appraisal of all published reviews that have used a systematic approach to find primary studies assessing the clinical efficacy of TENS for any type of acute and chronic pain in adults. Our appraisal is the largest to date, and included 169 reviews, of which 154 were systematic reviews and 37 were published by the Cochrane Collaboration. Our appraisal reveals an overwhelming quantity of redundant primary and secondary research that spans over three decades, resulting in stagnation of evidence and uncertainty about efficacy. Nevertheless, we believe that our appraisal provides 'suggestive evidence' that pain intensity is lower during or immediately after TENS compared with control interventions for a variety of conditions. Scrutiny of tallies and effect size estimates did not suggest that there were any major differences between pain duration (i.e., acute versus chronic) nor types of pain (e.g., musculoskeletal, post-operative, labour, neuropathic etc.). Our appraisal exposes shortcomings in research to date, including inconsistencies in methodologies, analyses and findings. We will consider the limitations and strengths of our appraisal before discussing the implications of the findings and issues arising for clinical practice and future research.

\subsection{Limitations of Our Appraisal}

Potential limitations of our appraisal process include:

- Absence of an analysis of adverse events;

- Absence of a quality assessment of included reviews;

- Absence of an analysis of TENS technique, dose or timing of outcomes on judgements. We will discuss each of these in turn. 


\subsubsection{Absence of an Analysis of Adverse Events}

We were unable to appraise adverse events because of a paucity of information in reviews. Few reviews had pre-specified protocols to analyse adverse event data. When information was available it was usually a brief narrative of adverse events collected spontaneously within trials. The absence of descriptions of adverse events within trial reports and reviews implies absence of adverse events of any consequence, although we cannot be entirely certain of this

\subsubsection{Absence of a Quality Assessment of Included Reviews}

We pre-specified that we would not formally assess the quality of systematic reviews because this has already been undertaken in overviews of systematic reviews. Gibson et al. [6], in their overview of eight Cochrane reviews, judged systematic review methodology to be good, but the quality of RCTs in reviews were very low. In other words, systematic review findings are only as good as the quality of studies assessed. We believe that adequacy of sample size for pooled data is the critical factor when judging meta-analyses findings for TENS, and our appraisal accounted for this when judging review evidence. Thus, we do not believe that undertaking a formal quality assessment of review would alter the outcome of our appraisal or add further insight into the nature of the evidence at our disposal.

4.2.3. Absence of an Analysis of TENS Technique, Dose or Timing of Outcomes on Judgements

It was not our intention to undertake a granular analysis of TENS technique, dose or timing of outcomes on outcome. In 2021, we published a comprehensive review of factors influencing the effects of TENS on pain that found no robust evidence of a relationship between specific electrical characteristics of TENS and clinically meaningful outcomes in patients with different types of pain [235]. Evidence suggested that a strong non-painful TENS sensation at, or close to the site of pain, was the active ingredient for TENS and patients adjust the qualities of this sensation according to personal preference, which may vary within and between treatments. We argued that it may be more appropriate to view TENS as a 'blunt tool' to generate a pleasant sensory experience to ease pain rather than a 'precise tool' enabling selection of specific electrical characteristics for specific types of pain. In other words, TENS should be considered as providing 'sensory soothing', akin to rubbing, warming and cooling the skin. Thus, we do not believe TENS technique, dose or precise timing of outcomes have influenced the gross-level findings of our appraisal.

\subsection{Challenges Encountered Conducting Our Descriptive Analysis}

We encountered operational challenges during screening of reports and whilst extracting, categorising and tallying data. We will discuss each of these in turn.

\subsubsection{Screening Reports for Inclusion}

Screening reports proved challenging. There were instances of multiple citations of reviews with subtle differences in publication dates and/or authorship teams; and multiple reports of the same systematic review and meta-analysis, including some Cochrane reviews published as shorter or extended reports in journals. We gave careful consideration to our approach to screen reports for inclusion in our appraisal to reduce the incidence of 'double counting', as described in the Section 2 and Supplementary Materials. Some Cochrane reviews were cited as 'Withdrawn' and without an accompanying explanation (e.g., Nnoaham and Kumbang [236]). Originally, Cochrane reviews could be withdrawn for a variety of reasons, including retraction of the review due to errors or a change in focus of updated reviews, e.g., the review being split into multiple reviews. Cochrane have recently updated their policy so that reviews are only withdrawn in 'exceptional circumstances' when concern arises about the conduct or reporting, such as serious error(s) in the review process, scientific misconduct, or a breach of Cochrane's conflict of interest policy. We considered each withdrawn review on a case-by-case basis. For example, we 
included a review by Nnoaham and Kumbang that was withdrawn in 2014 [236] as it met our eligibility criteria, had not been subsequently updated, and had not been withdrawn for reasons associated with reporting errors or conduct.

\subsubsection{Extracting, Categorising and Tallying Data}

Selecting data to extract from reviews and meta-analyses was challenging due to unclear and inconsistent reporting of trial arm sample sizes, values for overall effect size estimates, and the number of studies and participants in reviews versus meta-analyses. Some reviews and meta-analyses had a mixture of RCTs and non-RCTs. Many TENS interventions were administered in combination with other treatments including rescue medication, leading to 'contamination' of outcome data. Nevertheless, we do not believe that this impacted on the accuracy of our analysis of characteristics, outcomes or conclusion.

We used two investigators to independently extract, count and spot check the accuracy of data in our spreadsheet. Nevertheless, the size and complexity of the data extraction, coding and counting is likely to have resulted in the introduction of an occasional random error. We do not believe that this will have any significant impact on the accuracy of tallies in our descriptive analyses. The intention of our analysis was to offer insights to the characteristics of the systematic review literature as a whole rather than minutia.

We experienced challenges categorising types of pain, especially in relation to medical diagnoses. For example, Desmeules et al. [170] published a systematic review that evaluated rotator cuff tendinopathy which we categorised as tendinopathy, although it could equally have been included within our analysis of shoulder pain or musculoskeletal pain. We are confident that potential violations of categorisation were negligible. Nevertheless, the appropriateness of classifying painful conditions at a granular level, especially when evaluating treatments for symptomatic relief of pain via neuromodulation, is not without complication because medical conditions may present with a variety of painful symptoms resulting from multiple causes. For example, Sawant et al. [79] and Jawahar et al. [193] evaluated TENS for central neuropathic pain in individuals with multiple sclerosis, whereas Amatya et al. [192] evaluated TENS for chronic pain in individuals with multiple sclerosis without reference to central neuropathic pain and all three reviews included an RCT by Warke et al. [37] that evaluated chronic low-back pain in a multiple sclerosis population. It is a matter for debate whether chronic low back pain is a direct or indirect result of multiple sclerosis; was centrally or peripherally driven; was of neuropathic origin; and/or presented with symptoms that are considered to be characteristic in quality to neuropathic pain. We are of the view the primary mechanism of pain relief during TENS is via neuromodulation and therefore outcome would not depend to any great extent on specific pain mechanisms.

Readers may disagree with our categorisation and organisation of types of pain for some of our included reviews. Our approach was pragmatic, taking into consideration the number of available reviews and types of pain frequently described by clinicians. We considered categorising conditions according to the ICD-11 system for chronic pain, yet this can be problematic $[237,238]$. For example, non-specific chronic low back pain is considered by most clinicians as a musculoskeletal condition and managed in clinical settings associated with secondary musculoskeletal pain such as osteoarthritis, yet it is categorised in ICD-11 as chronic primary pain rather than secondary musculoskeletal pain. Some chronic primary pains are not similar in character to non-specific chronic low back pain e.g., complex regional pain syndrome. We used a robust approach to prevent 'double counting' so we do not believe that the way we organised reporting of type of pain affected the outcome of our descriptive analyses.

Finally, our approach to assigning authors' conclusions was subjective and biased toward a dichotomous judgement of benefit or no benefit, if at all possible. We often encountered illogical statements such as ‘... TENS may be beneficial, but evidence was inconclusive ... ' which could just as easily have been reverse framed as '... TENS may be not beneficial, but evidence is inconclusive ... '. Ideally, the statement should be framed 'It is not possible to determine efficacy because evidence is inconclusive'. As it was not our 
intention to tally definitive outcome of efficacy but rather to explore the structure, tone and direction of statements as reflected by the authors' sense of efficacy, we assigned ' ... TENS may be beneficial, but evidence was inconclusive ... ' as 'Benefit'; and '... TENS is not beneficial, but evidence is inconclusive ... ' as 'Not Benefit'. Despite this, we still recorded a high quantity of 'Inconclusive' outcomes. Importantly, our analysis reveals that many conclusions were framed using imprecise, contradictory or illogical language, with a bias towards evidence of possible benefits rather than no benefit.

Overall, the operational challenges faced whilst undertaking this appraisal provide useful insights into factors that influence outcomes of reviews. In our opinion, the limitations discussed above do not impact to any significant degree on the gross findings from our appraisal. We emphasise that the intention of our appraisal was to overview the characteristics and outcomes of systematic reviews evaluating clinical efficacy but not to determine efficacy per se.

\subsection{Strengths of Our Appraisal}

The strength of our appraisal is that it is the first to adopt a systematic, comprehensive and analytical approach to evaluate the full extent of systematic review literature on TENS. Thus, our appraisal can be used as a 'one-stop resource' for patients, clinicians, funders and policy makers. Our approach is transparent and our operational aide memoires (Supplementary Materials) enable replication of our methods and analyses. We pre-specified gold standard criteria for sufficient data on which to base judgements about overall estimates of effect size of meta-analyses. However, our intention was to describe and appraise the literature rather than undertake a formal evaluation of primary source data. Thus, we pre-specified that we would not attempt to extract primary source data for meta-analysis because we are already conducting a systematic review and meta-analysis that will do so [15].

\subsection{Comments on the Body of Evidence}

\subsubsection{Unnecessary/Redundant Systematic Reviews}

Our appraisal revealed instances of multiple reports of the same systematic review and revealed a proliferation of unnecessary reviews in the preceding three decades. A variety of factors are likely responsible including pressures for academics and clinicians to publish research for career progression, the low running costs of undertaking 'desk based' reviews, and an ever-increasing array of journals in which to publish. Our appraisal also revealed a high incidence of unnecessary systematic reviews, with more systematic reviews than RCTs for a number of painful conditions (e.g., non-specific chronic low back pain). Some reviews included forest plots of $n=1$, which could give a false impression of metaanalysis to the gullible reader. The proliferation of unnecessary, misleading, conflicting and inconclusive systematic reviews and meta-analyses has been recognised as a serious problem in medicine and health care, often confusing rather than clarifying benefits and harms of treatments [239]. This is particularly apparent in the body of literature on TENS, and it has resulted in conflicting clinical guidelines and much confusion for practitioners and patients.

\subsubsection{Variability in the Reporting and Execution of Reviews}

There was variability in the way that review methodology and findings were communicated. Cochrane reviews provided the greatest depth, detail and consistency of reporting. Reports of reviews undertaken by some learned societies lacked sufficient detail to replicate methodology, reducing confidence in operationalization of review methodology process and subsequent conclusions (e.g., Dubinsky et al. [115], rebuttal by Johnson and Walsh [116]). That said, even well written, systematic reviews do not necessarily assure a well conducted evaluation, as most reports did not provide specific details about operational aspects of conducting the review. Most reports suggested that investigators followed standard systematic review methodology, although we revealed inconsistency in included 
studies, risk of bias judgements, clinical outcomes, measurement timepoints and the nature of the effect size estimated between reviews of identical pain conditions. We suspect this is due to operational variations when conducting the review.

Specific operational aspects of undertaking reviews remain absent from review reports due to constraints on editorial space. Few reports had Supplementary Materials, and those that did tended to provide details of numerical data supporting analysis and/or details about the characteristics of studies. Few, if any, provided operational aide memoires to facilitate critique and replication of methodological steps taken during review. We recommend that reviewers should develop operational aide memoires specific to their reviews (e.g., screening and risk of bias judgments) and based on 'gold standard' guidance (e.g., from the Cochrane Handbook). This will facilitate consistency of decision making within review teams, replication of decision-making processes by other review teams, and open debate about operational procedures. These aide memoires can be published as Supplementary Materials as we have done for this appraisal (Supplementary Materials).

\subsubsection{Exaggeration of Process and Findings}

There was evidence of overstatement of all aspects of the review process in reports. For example, Zhu et al. [75] stated in the Abstract that there were six RCTs involving 529 patients in their meta-analysis, suggesting a modest amount of pooled data. However, in reality there were three separate meta-analyses each consisting of only two RCTs, and none had a total sample of pooled data greater than 210 participants (i.e., VAS TENS vs. control, two RCTs, $n=51$ vs. 51; VAS at 3 weeks TENS vs. control, 2 RCTs, $n=103$ vs. 102; post-operative morphine consumption TENS vs. Control, 2 RCTs, $n=46$ vs. 43). For clarity, we recommend that reviewers should include $n$ values for the trial arms of the largest pooled data set in report Abstracts and summary statements of findings.

Also, as described previously, we found that many reviewers tended to frame inconclusive findings in a positive tone, e.g., 'might be effective, despite a paucity of data' rather than a negative tone, e.g., 'might be ineffective, despite a paucity of data', or noncommittal, e.g., 'insufficient data to judge' or 'sufficient data that is conflicting'. A minority of conclusions were framed inconclusive findings in a negative tone, e.g., 'no evidence of benefit'. We recommend that authors pay more attention to the precision of language when constructing concluding statements, as this can have a major impact on the take-home message. No evidence of benefit is not the same as evidence of no benefit.

\subsubsection{Inadequacy of RCT Design}

All reports of systematic reviews stated that the quality of RCTs was low and that larger better designed RCTs were needed in the future. Our appraisal found RCTs to be simplistic, parallel group or cross-over in design. Reviewers persistently criticized inadequate sample sizes, lack of 'blinding' of comparator interventions, and heterogeneous TENS technique, dose, and regimen. Previously, we have commented on long-standing failure to address methodological deficiencies in TENS trials and have published attributes, criteria and operational solutions for undertaking an ideal TENS RCT [240]. We have recommended the use of enriched enrolment randomised withdrawal trials to evaluate the efficacy of TENS in real world situations [15,235].

\subsection{Stagnation of Knowledge over Three Decades}

Our appraisal provides interesting insights into the evolution of systematic review evidence over three decades. In the early 1970s Long et al., concluded that " ... the initial success that we have gained to date suggests that cutaneous electrical stimulation will be a significant advance in our ability to treat chronic pain" ([2], p. 267). The authors of the earliest systematic reviews published in the 1990s concluded "The use of TENS in chronic pain may well be justified but it has not been seen" ([3], p. 49) ... "There is a requirement for a randomised trial to address the issue. .. Without it, a potentially valuable intervention may be underused, or a useless intervention may continue in use" ([3], p. 49). "There is insufficient evidence to draw any 
conclusions about the effectiveness of transcutaneous electrical nerve stimulation (TENS) for the treatment of chronic pain in adults ... Large multi-centre randomised controlled trials of TENS in chronic pain are urgently needed." Carroll et al., 2001 ([97], p. 2). In 2020, Gibson et al. [6] concluded "We were therefore unable to conclude with any confidence that, in people with chronic pain, TENS is harmful, or beneficial for pain control, disability, health-related quality of life, use of pain-relieving medicines, or global impression of change" ([6], p. 2). " . . there is an urgent need to undertake large RCTs to examine its effectiveness"([6], p. 9).

The stagnation of evidence is the result of a lack of appetite to change the approach to evaluating TENS efficacy. Our appraisal is unique because of the extensive scope of the review (i.e., all types of pain) and the comprehensive nature of the search of literature and subsequent criterion-based judgements of efficacy based on systematic reviews with sufficient pooled data for meta-analysis.

\subsection{The Efficacy of TENS}

Our tally of authors' conclusions found that the majority of systematic reviews were inconclusive. Only a small proportion of reviews included a meta-analysis of pooled data and most did not pool sufficient data to be confident of claims of benefit. These findings are consistent with the most recent Cochrane reviews on acute [83] and chronic pain [6]. Both were inconclusive. The Cochrane review on acute pain was limited in scope, only assessing TENS as a standalone treatment resulting in the exclusion of a large quantity of studies on post-operative pain [83]. The most recent Cochrane review evaluating TENS for chronic pain included 8 Cochrane reviews and a descriptive analysis of 51 RCTs, without meta-analysis because they judged there to be considerable heterogeneity associated with clinical conditions, treatment protocols and study methodology including inadequate sample sizes [6]. Thus, the vast majority of systematic reviews spanning half a century have added little to knowledge and if anything, have fuel long-standing uncertainty about TENS efficacy.

Our appraisal is the first to graphically summarise all available effect size estimates of pain intensity (continuous) data and suggests that pain intensity is lower during TENS compared with controls, as most confidence intervals of overall effect size did not bisect the line of no difference. Most meta-analyses failed to reach our threshold for sufficient data to have confidence in the precision of the estimate (i.e., pooled analysis of $\geq 500$ events). Thus, we were unable to undertake any formal summary analysis of the effect sizes of all meta-analyses because inconsistency in calculations to estimate effect size in reviews hindered any meaningful comparison of equivalent outcomes (e.g., see Tables 2 and 3, Figure 11). Nevertheless, there were two meta-analyses with sufficient data and both were in favour of TENS; for chronic musculoskeletal pain [10] and for labour pain [26]. We also identified one meta-analysis with sufficient data to suggest that there was lower post-operative analgesic consumption during TENS compared with control [11].

In summary, we believe that our appraisal provides persuasive rather than compelling evidence that pain intensity is lower during or immediately after TENS compared with control interventions for acute and chronic pain. As a consequence, we believe that practitioners and policy makers should offer TENS as a treatment option for symptomatic relief of pain.

\subsection{Implications for Clinical Practice and Future Research}

TENS is a complex intervention and users need to personalise their treatment strategy according to their personal needs [241]. This involves learning how to select beneficial electrode positions and electrical characteristics (pulse amplitude, frequency, and pattern) based on their pain at that moment. Thus, users need to learn how to optimise benefits and minimize problems through trial and error and in line with good practice guidelines [1,242,243].

Recently, the NICE guidelines for the assessment of chronic pain and management of chronic primary pain recommended that TENS should not be offered [157]. The NICE excluded an evaluation of TENS for non-specific low back pain because separate guidance 
had already been published for the management of non-specific low back pain in 2016 [244]. This meant that data from studies evaluating TENS for non-specific low back pain were absent from the estimation of the overall effect size, which was calculated from only two studies, both on fibromyalgia. Although inclusion of the non-specific chronic low back pain studies in the meta-analysis would be unlikely to have changed the precision or confidence in effect size estimate, it does highlight the difficulty of categorising pain according to medical condition.

Our appraisal revealed 169 reviews that focused on pain associated with a variety of specific medical conditions with the majority of the common pain diagnoses covered. There was no evidence in our appraisal that the efficacy of TENS varied according to medical diagnoses, suggesting that TENS effects are generic, irrespective of the type of pain. We found no strong evidence that efficacy depended on specific electrical characteristics of TENS. Nevertheless, this would need to be confirmed in a meta-analysis that explored clinical heterogeneity (e.g., various types of pain and treatment protocols), and also statistical (i.e., $\mathrm{I}^{2}$ ) and methodological (e.g., high risk of bias) heterogeneity, using sensitivity and/or subgroup analyses. We have published a protocol for such a meta-analysis that will use a GRADE approach to account for the influence of study limitations (risk of bias), publication bias and inconsistency, indirectness and imprecision on confidence and certainty in the effect size estimate [15].

We also recommend that more ecologically valid RCTs are needed to evaluate TENS in 'real-life' settings such as self-administering TENS at home for chronic pain, capturing what patients choose to use rather than what practitioners or investigators prescribe. Participants should be actively engaged in the 'design' of their treatment schedule and choice of outcome measures meaningful to their needs. An enriched enrolment randomised withdrawal trial design meets these requirements and we have described in detail the characteristics of such a trial [235].

\section{Conclusions}

Our intention is that this appraisal of all available systematic reviews and metaanalyses of RCTs evaluating the effect of TENS on pain intensity will serve as a useful reference source for practitioners, researchers and commissioners. Our appraisal charts the research evidence underpinning long-standing uncertainty about clinical efficacy. Our appraisal reveals examples of meta-analyses with 'sufficient data' demonstrating benefit. There were no examples of meta-analyses with 'sufficient data' demonstrating no benefit. Therefore, we recommend that TENS should be considered as a treatment option.

However, when taken as a whole, the systematic review evidence is not compelling because of a considerable quantity of systematic reviews with 'insufficient data' contributing to meaningless and confusing literature that cloud the issue. We recommend a metaanalysis that pools all available RCT data, irrespective of type of pain, to estimate effect size for pain intensity. Going forward, more ecologically valid clinical trials of TENS are required using enriched enrolment with randomised withdrawal trial designs.

Ultimately, we hope that our appraisal catalyses a reflection on this situation and the need for a stepwise change in the way we evaluate treatments like TENS, where confident judgements about efficacy seem elusive.

Supplementary Materials: The following are available online at https:/ /www.mdpi.com/article/10 .3390/medicina57101060/s1, and includes Search Terms: Operational Aide Memoires and a Table of Excluded Records with Reasons [245-358].

Author Contributions: Conceptualization, M.I.J. and P.G.W.; methodology, M.I.J. and P.G.W.; software, Leeds Beckett University; validation, C.A.P., G.J., P.G.W. and M.I.J.; formal analysis, C.A.P., G.J., P.G.W. and M.I.J.; resources, M.I.J.; data curation, C.A.P., G.J., P.G.W. and M.I.J.; writing-original draft preparation, M.I.J.; writing—review and editing, C.A.P., G.J., P.G.W. and M.I.J.; visualization, M.I.J.; supervision, M.I.J.; project administration, M.I.J.; funding acquisition, M.I.J. All authors have read and agreed to the published version of the manuscript. 
Funding: This research was funded by GlaxoSmithKline (GSK) Consumer Healthcare, Nyon, Switzerland with an Investigator Sponsored Study grant, award/grant number N/A. The funder had no role in study design, data collection, data analysis, data interpretation, or writing of the report. The corresponding author had full access to all the data in the study and had final responsibility for the decision to submit for publication.

Institutional Review Board Statement: Not applicable.

Informed Consent Statement: Not applicable.

Data Availability Statement: Extracted data is available on request from M.I.J.

Acknowledgments: We wish to express our gratitude to the reviewers for their constructive advice.

Conflicts of Interest: All authors have completed the ICMJE uniform disclosure form and declare the following: C.A.P., G.J., and P.G.W. declare no competing interests; M.I.J. reports that he has received royalties from Oxford University for his book TENS: Research to support clinical practice, and M.I.J.'s employer has received support from Glaxo-SmithKline, TENSCare Ltd., and LifeCare Ltd., for expert consultancy services. All authors were involved in conducting reviews that were considered for inclusion in the work submitted for publication. The funders had no role in the design of the study; in the collection, analyses, or interpretation of data; in the writing of the manuscript, or in the decision to publish the results.

\section{References}

1. Johnson, M. Transcutaneous Electrical Nerve Stimulation (TENS). Research to Support Clinical Practice; Oxford University Press: Oxford, UK, 2014.

2. Long, D.M. Cutaneous afferent stimulation for relief of chronic pain. Clin. Neurosurg. 1974, 21, 257-268. [CrossRef]

3. McQuay, H.J.; Moore, R.A.; Eccleston, C.; Morley, S.; Williams, A.C. Systematic review of outpatient services for chronic pain control. Health Technol. Assess. 1997, 1, 1-135. [CrossRef]

4. McQuay, H.; Moore, A. TENS in acute postoperative pain. In An Evidence-Based Resource for Pain Relief; McQuay, H., Moore, A., Eds.; Oxford University Press: Oxford, UK, 1998; pp. 172-178.

5. Carroll, D.; Tramer, M.; McQuay, H.; Nye, B.; Moore, A. Randomization is important in studies with pain outcomes: Systematic review of transcutaneous electrical nerve stimulation in acute postoperative pain. Br. J. Anaesth. 1996, 77, 798-803. [CrossRef] [PubMed]

6. Gibson, W.; Wand, B.M.; Meads, C.; Catley, M.J.; O'Connell, N.E. Transcutaneous electrical nerve stimulation (TENS) for chronic pain-An overview of Cochrane Reviews. Cochrane Database Syst. Rev. 2019, 2, CD011890. [CrossRef] [PubMed]

7. Travers, M.J.; O'Connell, N.E.; Tugwell, P.; Eccleston, C.; Gibson, W. Transcutaneous electrical nerve stimulation (TENS) for chronic pain: The opportunity to begin again. Cochrane Database Syst. Rev. 2020, 4, ED000139. [CrossRef] [PubMed]

8. Moore, R.A.; Derry, S.; McQuay, H.J.; Straube, S.; Aldington, D.; Wiffen, P.; Bell, R.F.; Kalso, E.; Rowbotham, M.C. Clinical effectiveness: An approach to clinical trial design more relevant to clinical practice, acknowledging the importance of individual differences. Pain 2010, 149, 173-176. [CrossRef] [PubMed]

9. Moore, R.A.; Gavaghan, D.; Tramer, M.R.; Collins, S.L.; McQuay, H.J. Size is everything-large amounts of information are needed to overcome random effects in estimating direction and magnitude of treatment effects. Pain 1998, 78, 209-216. [CrossRef]

10. Johnson, M.; Martinson, M. Efficacy of electrical nerve stimulation for chronic musculoskeletal pain: A meta-analysis of randomized controlled trials. Pain 2007, 130, 157-165. [CrossRef]

11. Bjordal, J.M.; Johnson, M.I.; Ljunggreen, A.E. Transcutaneous electrical nerve stimulation (TENS) can reduce postoperative analgesic consumption. A meta-analysis with assessment of optimal treatment parameters for postoperative pain. Eur. J. Pain 2003, 7, 181-188. [CrossRef]

12. Knotkova, H.; Hamani, C.; Sivanesan, E.; Le Beuffe, M.F.E.; Moon, J.Y.; Cohen, S.P.; Huntoon, M.A. Neuromodulation for chronic pain. Lancet 2021, 397, 2111-2124. [CrossRef]

13. Gibson, W.; Wand, B.M.; O'Connell, N.E. Transcutaneous electrical nerve stimulation (TENS) for neuropathic pain in adults. Cochrane Database Syst. Rev. 2017, 9, CD011976. [CrossRef]

14. Wu, L.C.; Weng, P.W.; Chen, C.H.; Huang, Y.Y.; Tsuang, Y.H.; Chiang, C.J. Literature Review and Meta-Analysis of Transcutaneous Electrical Nerve Stimulation in Treating Chronic Back Pain. Reg. Anesth. Pain Med. 2018, 43, 425-433. [CrossRef] [PubMed]

15. Johnson, M.I.; Jones, G.; Paley, C.A.; Wittkopf, P.G. The clinical efficacy of transcutaneous electrical nerve stimulation (TENS) for acute and chronic pain: A protocol for a meta-analysis of randomised controlled trials (RCTs). BMJ Open 2019, 9, e029999. [CrossRef]

16. Dechartres, A.; Altman, D.G.; Trinquart, L.; Boutron, I.; Ravaud, P. Association between Analytic Strategy and Estimates of Treatment Outcomes in Meta-analysesAnalytic Strategy and Outcomes in Meta-analysesAnalytic Strategy and Outcomes in Meta-analyses. JAMA 2014, 312, 623-630. [CrossRef] 
17. Dechartres, A.; Trinquart, L.; Boutron, I.; Ravaud, P. Influence of trial sample size on treatment effect estimates: Metaepidemiological study. BMJ 2013, 346, f2304. [CrossRef] [PubMed]

18. Moore, A.R.; Eccleston, C.; Derry, S.; Wiffen, P.; Bell, R.F.; Straube, S.; McQuay, H. “Evidence” in chronic pain-establishing best practice in the reporting of systematic reviews. Pain 2010, 150, 386-389. [CrossRef] [PubMed]

19. Moore, R.A.; Derry, S.; Wiffen, P.J. Challenges in design and interpretation of chronic pain trials. Br. J. Anaesth. 2013, 111, 38-45. [CrossRef] [PubMed]

20. Cruccu, G.; Aziz, T.Z.; Garcia-Larrea, L.; Hansson, P.; Jensen, T.S.; Lefaucheur, J.P.; Simpson, B.A.; Taylor, R.S. EFNS guidelines on neurostimulation therapy for neuropathic pain. Eur. J. Neurol. 2007, 14, 952-970. [CrossRef] [PubMed]

21. Cruccu, G.; Garcia-Larrea, L.; Hansson, P.; Keindl, M.; Lefaucheur, J.P.; Paulus, W.; Taylor, R.; Tronnier, V.; Truini, A.; Attal, N. EAN guidelines on central neurostimulation therapy in chronic pain conditions. Eur. J. Neurol. 2016, 23, 1489-1499. [CrossRef]

22. Dowswell, T.; Bedwell, C.; Lavender, T.; Neilson, J.P. Transcutaneous electrical nerve stimulation (TENS) for pain relief in labour. Cochrane Database Syst. Rev. 2009, 2, CD007214. [CrossRef]

23. Bedwell, C.; Dowswell, T.; Neilson, J.P.; Lavender, T. The use of transcutaneous electrical nerve stimulation (TENS) for pain relief in labour: A review of the evidence. Midwifery 2011, 27, e141-e148. [CrossRef]

24. Claydon, L.; Chesterton, L. Does transcutaneous electrical nerve stimulation (TENS) produce 'dose-responses'? A review of systematic reviews on chronic pain. Phys. Rev. 2008, 13, 450-463. [CrossRef]

25. Jones, L.; Othman, M.; Dowswell, T.; Alfirevic, Z.; Gates, S.; Newburn, M.; Jordan, S.; Lavender, T.; Neilson, J.P. Pain management for women in labour: An overview of systematic reviews. Cochrane Database Syst. Rev. 2012, 3, CD009234. [CrossRef]

26. Thuvarakan, K.; Zimmermann, H.; Mikkelsen, M.K.; Gazerani, P. Transcutaneous Electrical Nerve Stimulation as a Pain-Relieving Approach in Labor Pain: A Systematic Review and Meta-Analysis of Randomized Controlled Trials. Neuromodulation 2020, 23, 732-746. [CrossRef] [PubMed]

27. Topuz, O.; Ozfidan, E.; Ozgen, M.; Ardic, F. Efficacy of transcutaneous electrical nerve stimulation and percutaneous neuromodulation therapy in chronic low back pain. J. Back Musculoskelet. Rehabil. 2004, 17, 127-133. [CrossRef]

28. Facci, L.M.; Nowotny, J.P.; Tormem, F.; Trevisani, V.F. Effects of transcutaneous electrical nerve stimulation (TENS) and interferential currents (IFC) in patients with nonspecific chronic low back pain: Randomized clinical trial. Sao Paulo Med. J. 2011, 129, 206-216. [CrossRef]

29. Ratajczak, B.; Hawrylak, A.; Demidas, A.; Kuciel-Lewandowska, J.; Boerner, E. Effectiveness of diadynamic currents and transcutaneous electrical nerve stimulation in disc disease lumbar part of spine. J. Back Musculoskelet. Rehabil. 2011, 24, 155-159. [CrossRef]

30. Sahin, N.; Albayrak, I.; Ugurlu, H. Effect of Different Transcutaneous Electrical Stimulation Modalities on Cervical Myofascial Pain Syndrome. J. Musculoskelet. Pain 2011, 19, 18-23. [CrossRef]

31. Alizade, M.H.; Ahmadizad, S. A comparision of exercise therapy and transcutaneous electrical nerve stimulation for the treatment of chronic low back pain. World J. Sport Sci. 2009, 2, 43-47.

32. Itoh, K.; Itoh, S.; Katsumi, Y.; Kitakoji, H. A pilot study on using acupuncture and transcutaneous electrical nerve stimulation to treat chronic non-specific low back pain. Complement. Clin. Pr. 2009, 15, 22-25. [CrossRef]

33. Barker, K.L.; Elliott, C.J.; Sackley, C.M.; Fairbank, J.C. Treatment of chronic back pain by sensory discrimination training. A Phase I RCT of a novel device (FairMed) vs. TENS. BMC Musculoskelet. Disord. 2008, 9, 97. [CrossRef]

34. Kofotolis, N.D.; Vlachopoulos, S.P.; Kellis, E. Sequentially allocated clinical trial of rhythmic stabilization exercises and TENS in women with chronic low back pain. Clin. Rehabil. 2008, 22, 99-111. [CrossRef]

35. Thompson, J.W.; Bower, S.; Tyrer, S.P. A double blind randomised controlled clinical trial on the effect of transcutaneous spinal electroanalgesia (TSE) on low back pain. Eur. J. Pain 2008, 12, 371-377. [CrossRef]

36. Shimoji, K.; Takahashi, N.; Nishio, Y.; Koyanagi, M.; Aida, S. Pain relief by transcutaneous electric nerve stimulation with bidirectional modulated sine waves in patients with chronic back pain: A randomized, double-blind, sham-controlled study. Neuromodulation 2007, 10, 42-51. [CrossRef]

37. Warke, K.; Al-Smadi, J.; Baxter, D.; Walsh, D.; Lowe-Strong, A. Efficacy of transcutaneous electrical nerve stimulation (tens) for chronic low-back pain in a multiple sclerosis population: A randomized, placebo-controlled clinical trial. Clin. J. Pain 2006, 22, 812-819. [CrossRef]

38. Jarzem, P.F.; Harvey, E.J.; Arcaro, N.; Kaczorowski, J. Transcutaneous electrical nerve stimulation TENS for chronic low back pain. J. Musculoskelet. Pain 2005, 13, 3-9. [CrossRef]

39. Jarzem, P.F.; Harvey, E.J.; Arcaro, N.; Kaczorowski, J. Transcutaneous electrical nerve stimulation TENS for short-term treatment of low back pain-randomized double blind crossover study of sham versus conventional TENS. J. Musculoskelet. Pain 2005, 13, 11-17. [CrossRef]

40. Yokoyama, M.; Sun, X.; Oku, S.; Taga, N.; Sato, K.; Mizobuchi, S.; Takahashi, T.; Morita, K. Comparison of percutaneous electrical nerve stimulation with transcutaneous electrical nerve stimulation for long-term pain relief in patients with chronic low back pain. Anesth. Analg. 2004, 98, 1552-1556. [CrossRef] [PubMed]

41. Hsieh, R.L.; Lee, W.C. One-shot percutaneous electrical nerve stimulation vs. transcutaneous electrical nerve stimulation for low back pain: Comparison of therapeutic effects. Am. J. Phys. Med. Rehabil. 2002, 81, 838-843. [CrossRef]

42. Tsukayama, H.; Yamashita, H.; Amagai, H.; Tanno, Y. Randomised controlled trial comparing the effectiveness of electroacupuncture and TENS for low back pain: A preliminary study for a pragmatic trial. Acupunct. Med. 2002, 20, 175-180. [CrossRef] 
43. Cheing, G.L.; Hui_Chan, C.W. Transcutaneous electrical nerve stimulation: Nonparallel antinociceptive effects on chronic clinical pain and acute experimental pain. Arch. Phys. Med. Rehabil. 1999, 80, 305-312. [CrossRef]

44. Grant, D.J.; Bishop_Miller, J.; Winchester, D.M.; Anderson, M.; Faulkner, S. A randomized comparative trial of acupuncture versus transcutaneous electrical nerve stimulation for chronic back pain in the elderly. Pain 1999, 82, 9-13. [CrossRef]

45. Ghoname, E.A.; Craig, W.F.; White, P.F.; Ahmed, H.E.; Hamza, M.A.; Henderson, B.N.; Gajraj, N.M.; Huber, P.J.; Gatchel, R.J. Percutaneous electrical nerve stimulation for low back pain: A randomized crossover study. JAMA 1999, 281, 818-823, Erratum in 1999, 281, 1795. [CrossRef]

46. Moore, S.R.; Shurman, J. Combined neuromuscular electrical stimulation and transcutaneous electrical nerve stimulation for treatment of chronic back pain: A double-blind, repeated measures comparison. Arch. Phys. Med. Rehabil. 1997, 78, 55-60. [CrossRef]

47. Marchand, S.; Charest, J.; Li, J.; Chenard, J.; Lavignolle, B.; Laurencelle, L. Is TENS purely a placebo effect? A controlled study on chronic low back pain. Pain 1993, 54, 99-106. [CrossRef]

48. Gemignani, G.; Olivieri, I.; Ruju, G.; Pasero, G. Transcutaneous electrical nerve stimulation in ankylosing spondylitis: A double-blind study. Arthritis Rheum. 1991, 34, 788-789. [CrossRef]

49. Deyo, R.A.; Walsh, N.E.; Martin, D.C.; Schoenfeld, L.S.; Ramamurthy, S. A controlled trial of transcutaneous electrical nerve stimulation (TENS) and exercise for chronic low back pain. N. Engl. J. Med. 1990, 322, 1627-1634. [CrossRef] [PubMed]

50. Lehmann, T.; Russell, D.; Spratt, K.; Colby, H.; Liu, Y.; Fairchild, M.; Christensen, S. Efficacy of electroacupuncture and TENS in the rehabilitation of chronic low back pain patients. Pain 1986, 26, 277-290. [CrossRef]

51. Resende, L.; Merriwether, E.; Rampazo, E.P.; Dailey, D.; Embree, J.; Deberg, J.; Liebano, R.E.; Sluka, K.A. Meta-analysis of transcutaneous electrical nerve stimulation for relief of spinal pain. Eur. J. Pain 2018, 22, 663-678. [CrossRef] [PubMed]

52. Jauregui, J.J.; Cherian, J.J.; Gwam, C.U.; Chughtai, M.; Mistry, J.B.; Elmallah, R.K.; Harwin, S.F.; Bhave, A.; Mont, M.A. A Meta-Analysis of Transcutaneous Electrical Nerve Stimulation for Chronic Low Back Pain. Surg. Technol. Int. 2016, $28,296-302$.

53. Van Middelkoop, M.; Rubinstein, S.M.; Kuijpers, T.; Verhagen, A.P.; Ostelo, R.; Koes, B.W.; van Tulder, M.W. A systematic review on the effectiveness of physical and rehabilitation interventions for chronic non-specific low back pain. Eur. Spine J. 2011, 20, 19-39. [CrossRef] [PubMed]

54. Jamtvedt, G.; Dahm, K.T.; Christie, A.; Moe, R.H.; Haavardsholm, E.; Holm, I.; Hagen, K.B. Physical therapy interventions for patients with osteoarthritis of the knee: An overview of systematic reviews. Phys. Ther. 2008, 88, 123-136. [CrossRef] [PubMed]

55. Zhang, W.; Moskowitz, R.W.; Nuki, G.; Abramson, S.; Altman, R.D.; Arden, N.; Bierma-Zeinstra, S.; Brandt, K.D.; Croft, P.; Doherty, M.; et al. OARSI recommendations for the management of hip and knee osteoarthritis, part I: Critical appraisal of existing treatment guidelines and systematic review of current research evidence. Osteoarthr. Cart. 2007, 15, 981-1000. [CrossRef]

56. Jensen, I.; Harms-Ringdahl, K. Neck pain. Best Pr. Res. Clin. Rheumatol. 2007, 21, 93-108. [CrossRef]

57. Barreca, S.; Wolf, S.L.; Fasoli, S.; Bohannon, R. Treatment interventions for the paretic upper limb of stroke survivors: A critical review. Neurorehabilit. Neural Repair 2003, 17, 220-226. [CrossRef] [PubMed]

58. Burnett, M.; Lemyre, M. No. 345-Primary Dysmenorrhea Consensus Guideline. J. Obs. Gynaecol. Can. 2017, 39, 585-595. [CrossRef]

59. Latthe, P.M.; Champaneria, R.; Khan, K.S. Dysmenorrhoea. BMJ Clin. Evid. 2011, 2011, 0813. [PubMed]

60. Proctor, M.L.; Farquhar, C.M. Dysmenorrhoea. BMJ Clin. Evid. 2007, 2007, 0813.

61. Chou, R.; Huffman, L.H. Nonpharmacologic therapies for acute and chronic low back pain: A review of the evidence for an American Pain Society/American College of Physicians clinical practice guideline. Ann. Intern. Med. 2007, 147, 492-504. [CrossRef] [PubMed]

62. Brosseau, L.; Milne, S.; Robinson, V.; Marchand, S.; Shea, B.; Wells, G.; Tugwell, P. Efficacy of the transcutaneous electrical nerve stimulation for the treatment of chronic low back pain-A meta-analysis. Spine 2002, 27, 596-603. [CrossRef] [PubMed]

63. Keller, A.; Hayden, J.; Bombardier, C.; van Tulder, M. Effect sizes of non-surgical treatments of non-specific low-back pain. Eur. Spine J. 2007, 16, 1776-1788. [CrossRef]

64. Philadelphia, P. Philadelphia Panel evidence-based clinical practice guidelines on selected rehabilitation interventions for low back pain. Phys. Ther. 2001, 81, 1641-1674.

65. Stein, C.; Eibel, B.; Sbruzzi, G.; Lago, P.D.; Plentz, R.D. Electrical stimulation and electromagnetic field use in patients with diabetic neuropathy: Systematic review and meta-analysis. Braz. J. Phys. 2013, 17, 93-104. [CrossRef] [PubMed]

66. Jin, D.M.; Xu, Y.; Geng, D.F.; Yan, T.B. Effect of transcutaneous electrical nerve stimulation on symptomatic diabetic peripheral neuropathy: A meta-analysis of randomized controlled trials. Diabetes Res. Clin. Pr. 2010, 89, 10-15. [CrossRef] [PubMed]

67. Almeida, C.C.; Maldaner da Silva, V.Z.M.; Cipriano Junior, G.; Liebano, R.E.; Quagliotti Durigan, J.L. Transcutaneous electrical nerve stimulation and interferential current demonstrate similar effects in relieving acute and chronic pain: A systematic review with meta-analysis [with consumer summary]. Braz. J. Phys. 2018, 22, 347-354. [CrossRef] [PubMed]

68. Corbett, M.S.; Rice, S.J.; Madurasinghe, V.; Slack, R.; Fayter, D.A.; Harden, M.; Sutton, A.J.; Macpherson, H.; Woolacott, N.F. Acupuncture and other physical treatments for the relief of pain due to osteoarthritis of the knee: Network meta-analysis. Osteoarthr. Cart. 2013, 21, 1290-1298. [CrossRef]

69. Philadelphia Panel. Philadelphia Panel evidence-based clinical practice guidelines on selected rehabilitation interventions for knee pain. Phys. Ther. 2001, 81, 1675-1700. 
70. Arik, M.I.; Kiloatar, H.; Aslan, B.; Icelli, M. The effect of tens for pain relief in women with primary dysmenorrhea: A systematic review and meta-analysis. Explore 2020, 29, 2541. [CrossRef]

71. Cottrell, A.M.; Schneider, M.P.; Goonewardene, S.; Yuan, Y.; Baranowski, A.P.; Engeler, D.S.; Borovicka, J.; Dinis-Oliveira, P.; Elneil, S.; Hughes, J.; et al. Benefits and Harms of Electrical Neuromodulation for Chronic Pelvic Pain: A Systematic Review. Eur. Urol. Focus 2020, 6, 559-571. [CrossRef]

72. Price, C.I.; Pandyan, A.D. Electrical stimulation for preventing and treating post-stroke shoulder pain. Cochrane Database Syst. Rev. 2000, 4, CD001698. [CrossRef]

73. Zimpel, S.A.; Torloni, M.R.; Porfirio, G.J.; Flumignan, R.L.; da Silva, E.M. Complementary and alternative therapies for postcaesarean pain. Cochrane Database Syst. Rev. 2020, 9, CD011216. [CrossRef] [PubMed]

74. Li, J.; Song, Y. Transcutaneous electrical nerve stimulation for postoperative pain control after total knee arthroplasty: A meta-analysis of randomized controlled trials. Medicine 2017, 96, e8036. [CrossRef] [PubMed]

75. Zhu, Y.; Feng, Y.; Peng, L. Effect of transcutaneous electrical nerve stimulation for pain control after total knee arthroplasty: A systematic review and meta-analysis. J. Rehabil. Med. 2017, 49, 700-704. [CrossRef] [PubMed]

76. Zeng, C.; Li, H.; Yang, T.; Deng, Z.H.; Yang, Y.; Zhang, Y.; Lei, G.H. Electrical stimulation for pain relief in knee osteoarthritis: Systematic review and network meta-analysis. Osteoarthr. Cart. 2015, 23, 189-202. [CrossRef]

77. Chen, L.-X.; Zhou, Z.-R.; Li, Y.-L.; Ning, G.-Z.; Li, Y.; Wang, X.-B.; Feng, S.-Q. Transcutaneous electrical nerve stimulation in patients with knee osteoarthritis: Evidence from randomized-controlled trials. Clin. J. Pain 2016, 32, 146-154. [CrossRef]

78. Rutjes, A.W.; Nuesch, E.; Sterchi, R.; Kalichman, L.; Hendriks, E.; Osiri, M.; Brosseau, L.; Reichenbach, S.; Juni, P. Transcutaneous electrostimulation for osteoarthritis of the knee. Cochrane Database Syst. Rev. 2009, 4, CD002823. [CrossRef]

79. Sawant, A.; Dadurka, K.; Overend, T.; Kremenchutzky, M. Systematic review of efficacy of TENS for management of central pain in people with multiple sclerosis. Mult. Scler. Relat. Disord. 2015, 4, 219-227. [CrossRef]

80. Cherian, J.J.; Jauregui, J.J.; Leichliter, A.K.; Elmallah, R.K.; Bhave, A.; Mont, M.A. The effects of various physical non-operative modalities on the pain in osteoarthritis of the knee. Bone Jt. J. 2016, 98-B, 89-94. [CrossRef]

81. Salazar, A.P.; Stein, C.; Marchese, R.R.; Plentz, R.D.; Pagnussat, A.S. Electric Stimulation for Pain Relief in Patients with Fibromyalgia: A Systematic Review and Meta-analysis of Randomized Controlled Trials. Pain Physician 2017, 20, 15-25. [CrossRef]

82. Bjordal, J.M.; Johnson, M.I.; Ab Lopes-Martins, R.; Bogen, B.; Chow, R.; Ljunggren, A.E. Short-term efficacy of physical interventions in osteoarthritic knee pain. A systematic review and meta-analysis of randomised placebo-controlled trials. $B M C$ Musculoskelet. Disord. 2007, 8, 51. [CrossRef]

83. Johnson, M.I.; Paley, C.A.; Howe, T.E.; Sluka, K.A. Transcutaneous electrical nerve stimulation for acute pain. Cochrane Database Syst. Rev. 2015, 6, CD006142. [CrossRef] [PubMed]

84. Simpson, P.M.; Fouche, P.F.; Thomas, R.E.; Bendall, J.C. Transcutaneous electrical nerve stimulation for relieving acute pain in the prehospital setting: A systematic review and meta-analysis of randomized-controlled trials. Eur. J. Emerg. Med. 2014, 21, 10-17. [CrossRef] [PubMed]

85. Binny, J.; Joshua Wong, N.L.; Garga, S.; Lin, C.W.C.; Maher, C.G.; McLachlan, A.J.; Traeger, A.C.; Machado, G.C.; Shaheed, C.A. Transcutaneous electric nerve stimulation (TENS) for acute low back pain: Systematic review. Scand. J. Pain 2019, 19, 225-233. [CrossRef] [PubMed]

86. Machado, L.A.; Kamper, S.J.; Herbert, R.D.; Maher, C.G.; McAuley, J.H. Analgesic effects of treatments for non-specific low back pain: A meta-analysis of placebo-controlled randomized trials. Rheumatology 2009, 48, 520-527. [CrossRef] [PubMed]

87. Poitras, S.; Brosseau, L. Evidence-informed management of chronic low back pain with transcutaneous electrical nerve stimulation, interferential current, electrical muscle stimulation, ultrasound, and thermotherapy. Spine J. 2008, 8, 226-233. [CrossRef]

88. Zhou, J.; Dan, Y.; Yixian, Y.; Lyu, M.; Zhong, J.; Wang, Z.; Zhu, Y.; Liu, L. Efficacy of Transcutaneous Electronic Nerve Stimulation in Postoperative Analgesia After Pulmonary Surgery: A Systematic Review and Meta-Analysis. Am. J. Phys. Med. Rehabil. 2020, 99, 241-249. [CrossRef] [PubMed]

89. Sbruzzi, G.; Silveira, S.A.; Silva, D.V.; Coronel, C.C.; Plentz, R.D. Transcutaneous electrical nerve stimulation after thoracic surgery: Systematic review and meta-analysis of 11 randomized trials. Rev. Bras. Cir. Cardiovasc. 2012, 27, 75-87. [CrossRef]

90. Abou-Setta, A.M.; Beaupre, L.A.; Rashiq, S.; Dryden, D.M.; Hamm, M.P.; Sadowski, C.A.; Menon, M.R.; Majumdar, S.R.; Wilson, D.M.; Karkhaneh, M.; et al. Comparative effectiveness of pain management interventions for hip fracture: A systematic review. Ann. Intern. Med. 2011, 155, 234-245. [CrossRef]

91. Malone, M.D.; Strube, M.J. Meta-analysis of non-medical treatments for chronic pain. Pain 1988, 34, 231-244. [CrossRef]

92. Axon, D.R.; Patel, M.J.; Martin, J.R.; Slack, M.K. Use of multidomain management strategies by community dwelling adults with chronic pain: Evidence from a systematic review. Scand. J. Pain 2019, 19, 9-23. [CrossRef]

93. Baird, E.; Williams, A.; Hearn, L.; Amris, K. Interventions for treating persistent pain in survivors of torture. Cochrane Database Syst. Rev. 2017, 8, CD012051. [CrossRef]

94. Crawford, C.; Lee, C.; May, T. Physically oriented therapies for the self-management of chronic pain symptoms. Pain Med. 2014, 15 (Suppl. 1), S54-S65. [CrossRef] [PubMed]

95. Park, J.; Hughes, A.K. Nonpharmacological Approaches to the Management of Chronic Pain in Community-Dwelling Older Adults: A Review of Empirical Evidence. J. Am. Geriatr. Soc. 2012, 60, 555-568. [CrossRef] [PubMed]

96. Nnoaham, K.E.; Kumbang, J. Transcutaneous electrical nerve stimulation (TENS) for chronic pain. Cochrane Database Syst. Rev. 2008, 3, CD003222. 
97. Carroll, D.; Moore, R.A.; McQuay, H.J.; Fairman, F.; Tramer, M.; Leijon, G. Transcutaneous electrical nerve stimulation (TENS) for chronic pain. Cochrane Database Syst. Rev. 2001, 4, CD003222.

98. Reeve, J.; Menon, D.; Corabian, P. Transcutaneous electrical nerve stimulation (TENS): A technology assessment. Int. J. Technol. Assess. Health Care 1996, 12, 299-324. [CrossRef] [PubMed]

99. Samuel, S.R.; Maiya, G.A. Application of Low Frequency and Medium Frequency Currents in the Management of Acute and Chronic Pain-A Narrative Review. Indian J. Palliat. Care 2015, 21, 116-120. [CrossRef]

100. Khadilkar, A.; Odebiyi, D.O.; Brosseau, L.; Wells, G.A. Transcutaneous electrical nerve stimulation (TENS) versus placebo for chronic low-back pain. Cochrane Database Syst. Rev. 2008, 4, CD003008. [CrossRef]

101. Ely, S.; Barlas, P. Transcutaneous electrical acupoint stimulation for people with chronic musculoskeletal pain: An exploratory review. Phys. Rev. 2019, 24,377-388. [CrossRef]

102. Ely, S. Transcutaneous electrical nerve stimulation (TENS) at acupuncture points for the management of chronic pain: A narrative review. Physiotherapy 2016, 102, e90. [CrossRef]

103. Nunes, A.M.P.; Moita, J. Effectiveness of physical and rehabilitation techniques in reducing pain in chronic trapezius myalgia: A systematic review and meta-analysis. Int. J. Osteopath. Med. 2015, 18, 189-206. [CrossRef]

104. Almeida, M.O.; Silva, B.N.; Andriolo, R.B.; Atallah, A.N.; Peccin, M.S. Conservative interventions for treating exercise-related musculotendinous, ligamentous and osseous groin pain. Cochrane Database Syst. Rev. 2013, 6, CD009565. [CrossRef]

105. Bellini, C.; Monti, S.; Pillastrini, P. Physical Therapy Applied to Pathologies of Rehabilitative Interest. Sci. Riabil. 2011, 13, 37-45.

106. Vernon, H.; Schneider, M. Chiropractic management of myofascial trigger points and myofascial pain syndrome: A systematic review of the literature. J. Manip. Physiol. 2009, 32, 14-24. [CrossRef] [PubMed]

107. Rickards, L.D. The effectiveness of non-invasive treatments for active myofascial trigger point pain: A systematic review of the literature. Int. J. Osteopath. Med. 2006, 9, 120-136. [CrossRef]

108. O'Connor, R.; Hurley, D.A. The effectiveness of physiotherapeutic interventions in the management of delayed-onset muscle soreness: A systematic review. Phys. Rev. 2003, 8, 177-195. [CrossRef]

109. Philadelphia, P. Philadelphia Panel evidence-based clinical practice guidelines on selected rehabilitation interventions for shoulder pain. Phys. Ther. 2001, 81, 1719-1730.

110. Nascimento, P.R.C.D.; Costa, L.O.P.; Araujo, A.C.; Poitras, S.; Bilodeau, M. Effectiveness of interventions for non-specific low back pain in older adults. A systematic review and meta-analysis. Physiotherapy 2018, 105, 147-162. [CrossRef] [PubMed]

111. Bredow, J.; Bloess, K.; Oppermann, J.; Boese, C.K.; Lohrer, L.; Eysel, P. Conservative treatment of nonspecific, chronic low back pain: Evidence of the efficacy-A systematic literature review. Orthopade 2016, 45, 573-578. [CrossRef]

112. Ehrenbrusthoff, K.; Ryan, C.; Schofield, P.; Martin, D. Physical therapy management of older adults with chronic low back pain: A systematic review. J. Pain Manag. 2012, 5, 317-329.

113. Chou, R. Low back pain (chronic). BMJ Clin. Evid. 2010, 2010, 1116.

114. Hall, H.; McIntosh, G. Low back pain (chronic). BMJ Clin. Evid. 2008, 2008, 1116.

115. Dubinsky, R.M.; Miyasaki, J. Assessment: Efficacy of transcutaneous electric nerve stimulation in the treatment of pain in neurologic disorders (an evidence-based review): Report of the Therapeutics and Technology Assessment Subcommittee of the American Academy of Neurology. Neurology 2010, 74, 173-176. [CrossRef]

116. Johnson, M.; Walsh, D. Continued uncertainty of TENS effectiveness for pain relief. Nat. Rev. Rheumatol. 2010, 6, 314-316. [CrossRef] [PubMed]

117. Gaid, M.; Cozens, A. The role of transcutaneous electric nerve stimulation (TENS) for the management of chronic low back pain. Int. Musculoskelet. Med. 2009, 31, 19-23. [CrossRef]

118. Gutiérrez, H.; Ortiz, L. Evidence of the analgesic effect of physiotherapy in the low back pain syndrome. Rev. Iberoam. Fisioter. Kinesiol. 2009, 12, 84-95. [CrossRef]

119. Khadilkar, A.; Milne, S.; Brosseau, L.; Robinson, V.; Saginur, M.; Shea, B.; Tugwell, P.; Wells, G. Transcutaneous electrical nerve stimulation (TENS) for chronic low-back pain. Cochrane Database Syst. Rev. 2005, 3, CD003008.

120. Milne, S.; Welch, V.; Brosseau, L.; Saginur, M.; Shea, B.; Tugwell, P.; Wells, G. Transcutaneous electrical nerve stimulation (TENS) for chronic low back pain. Cochrane Database Syst. Rev. 2001, 2, CD003008.

121. Pengel, H.M.; Maher, C.G.; Refshauge, K.M. Systematic review of conservative interventions for subacute low back pain. Clin. Rehabil. 2002, 16, 811-820. [CrossRef]

122. Flowerdew, M.; Gadsby, G. A review of the treatment of chronic low back pain with acupuncture-like transcuatenous electrical nerve stimulation and transcutaneous electrical nerve stimulation. Complement. Med. 1997, 5, 193-201. [CrossRef]

123. Gadsby, G.; Flowerdew, M. Nerve stimulation for low back pain-A review. Nurs. Stand. 1997, 11, 32-33. [CrossRef]

124. McIntosh, G.; Hall, H. Low back pain (acute). BMJ Clin. Evid. 2011, 2011, 1102.

125. Martimbianco, A.L.C.; Porfirio, G.J.; Pacheco, R.L.; Torloni, M.R.; Riera, R. Transcutaneous electrical nerve stimulation (TENS) for chronic neck pain. Cochrane Database Syst. Rev. 2019, 12, CD011927. [CrossRef]

126. Binder, A.I. Neck pain. BMJ Clin. Evid. 2008, 2008, 1103.

127. Vernon, H.T.; Humphreys, B.K.; Hagino, C.A. A systematic review of conservative treatments for acute neck pain not due to whiplash. J. Manip. Physiol. 2005, 28, 443-448. [CrossRef] [PubMed]

128. Philadelphia, P. Philadelphia Panel evidence-based clinical practice guidelines on selected rehabilitation interventions for neck pain. Phys. Ther. 2001, 81, 1701-1717. 
129. Kjellman, G.V.; Skargren, E.I.; Oberg, B.E. A critical analysis of randomised clinical trials on neck pain and treatment efficacy. A review of the literature. Scand. J. Rehabil. Med. 1999, 31, 139-152. [CrossRef]

130. Aker, P.; Gross, A.; Goldsmith, C.; Peloso, P. Conservative management of mechanical neck pain: Systematic overview and meta-analysis. BMJ 1996, 313, 1291-1296. [CrossRef]

131. Gross, A.R.; Aker, P.D.; Goldsmith, C.H.; Peloso, P. Conservative management of mechanical neck disorders. A systematic overview and meta-analysis. Online J. Curr. Clin. Trials 1996. [PubMed]

132. Kroeling, P.; Gross, A.; Goldsmith, C.H.; Burnie, S.J.; Haines, T.; Graham, N.; Brant, A. Electrotherapy for neck pain. Cochrane Database Syst. Rev. 2013, 8, CD004251. [CrossRef]

133. Osiri, M.; Welch, V.; Brosseau, L.; Shea, B.; McGowan, J.; Tugwell, P.; Wells, G. Transcutaneous electrical nerve stimulation for knee osteoarthritis. Cochrane Database Syst. Rev. 2000, 4, CD002823.

134. Ferronato, L.; Cunha, H.M.; Machado, P.M.; dos Santos de Souza, G.; Limana, M.D.; Carelli Pereira de Avelar, N. Phisical modalities on the functional performance in knee osteoarthritis: A sytematic review. Fisioter. Mov. 2017, 30, 605-621. [CrossRef]

135. National Institute for Health and Care Excellence. Osteoarthritis: Care and Management. Available online: http://nice.org.uk/ guidance/cg177 (accessed on 29 August 2019).

136. Brosseau, L.; Yonge, K.; Marchand, S.; Robinson, V.; Osiri, M.; Wells, G.; Tugwell, P. Efficacy of transcutaneous electrical nerve stimulation for osteoarthritis of the lower extremities: A meta-analysis. Phys. Rev. 2004, 9, 213-233. [CrossRef]

137. Puett, D.; Griffin, M. Published trials of nonmedicinal and noninvasive therapies for hip and knee osteoarthritis. Ann. Intern. Med. 1994, 121, 133-140. [CrossRef]

138. Terracina, S.; Robba, C.; Prete, A.; Sergi, P.G.; Bilotta, F. Prevention and Treatment of Postoperative Pain after Lumbar Spine Procedures: A Systematic Review. Pain Pr. 2018, 18, 925-945. [CrossRef]

139. Yue, C.; Zhang, X.; Zhu, Y.; Jia, Y.; Wang, H.; Liu, Y. Systematic Review of Three Electrical Stimulation Techniques for Rehabilitation After Total Knee Arthroplasty. J. Arthroplast. 2018, 33, 2330-2337. [CrossRef]

140. Kerai, S.; Saxena, K.N.; Taneja, B.; Sehrawat, L. Role of transcutaneous electrical nerve stimulation in post-operative analgesia. Indian J. Anaesth. 2014, 58, 388-393. [CrossRef]

141. Caley, C. The effects of transcutaeous electrical nerve stimulation (TENS) in postoperative cardiothoracic pain: A systematic review. J. Physiother. Pain Assoc. 2012, 6-10.

142. Freynet, A.; Falcoz, P.E. Is transcutaneous electrical nerve stimulation effective in relieving postoperative pain after thoracotomy? Interact. Cardiovasc. Thorac. Surg. 2010, 10, 283-288. [CrossRef]

143. Sabino, G.S.; de Souza, M.V.S.; de Resende, M.A. Transcutaneous electrical nerve stimulation in thoracic or abdominal postoperative conditions. Fisioter. Mov. 2006, 19, 59-71.

144. Carroll, D.; Moore, R.A.; Tramer, M.R.; McQuay, H.J. Transcutaneous electrical nerve stimulation does not relieve labor pain: Updated systematic review. Contemp. Rev. Obs. Gynaecol. 1997, 9, 195-205.

145. National Institute for Health and Clinical Excellence. NICE Clinical Guideline 55 Intrapartum Care: Care of Healthy Women and Their Babies during Childbirth; National Institute for Health and Care Excellence: London, UK, 2007; pp. 1-65.

146. Angelo, P.H.M.; Ribeiro, K.C.L.; Lins, L.G.; de Holanda Araújo Rosendo, A.M.P.; de Sousa, V.P.S.; Micussi, M.T.A.B.C. Recursos não farmacológicos: Atuação da fisioterapia no trabalho de parto, uma revisão sistemática. Fisioter. Bras. 2016, 17, 285-292. [CrossRef]

147. Liddle, S.D.; Pennick, V. Interventions for preventing and treating low-back and pelvic pain during pregnancy. Cochrane Database Syst. Rev. 2015, 9, CD001139. [CrossRef] [PubMed]

148. Keskin, E.A.; Onur, O.; Keskin, H.L.; Gumus, I.I.; Kafali, H.; Turhan, N. Transcutaneous electrical nerve stimulation improves low back pain during pregnancy. Gynecol. Obs. Investig. 2012, 74, 76-83. [CrossRef] [PubMed]

149. Mafetoni, R.R.; Kakuda Shimo, A.K. Non-Pharmacological Methods of Pain Relief during Labor: Integrative review. Rev. Min. Enferm. 2014, 18, 513-520. [CrossRef]

150. Mello, L.F.; Nobrega, L.F.; Lemos, A. Transcutaneous electrical stimulation for pain relief during labor: A systematic review and meta-analysis. Rev. Bras. Fisioter. 2011, 15, 175-184. [CrossRef]

151. Simkin, P.; Bolding, A. Update on nonpharmacologic approaches to relieve labor pain and prevent suffering. J. Midwifery Womens Health 2004, 49, 489-504. [CrossRef]

152. Carroll, D.; Tramer, M.; McQuay, H.; Nye, B.; Moore, A. Transcutaneous electrical nerve stimulation in labour pain: A systematic review. Br. J. Obs. Gynaecol. 1997, 104, 169-175. [CrossRef]

153. Proctor, M.; Farquhar, C.; Stones, W.; He, L.; Zhu, X.; Brown, J. Transcutaneous electrical nerve stimulation for primary dysmenorrhoea. Cochrane Database Syst. Rev. 2002, 1, CD002123. [CrossRef]

154. Franco, J.V.A.; Turk, T.; Jung, J.H.; Xiao, Y.T.; Iakhno, S.; Garrote, V.; Vietto, V. Non-pharmacological interventions for treating chronic prostatitis/chronic pelvic pain syndrome. Cochrane Database Syst. Rev. 2018, 5, CD012551. [CrossRef]

155. Megia Garcia, A.; Serrano-Munoz, D.; Bravo-Esteban, E.; Ando Lafuente, S.; Avendano-Coy, J.; Gomez-Soriano, J. Analgesic effects of transcutaneous electrical nerve stimulation (TENS) in patients with fibromyalgia: A systematic review. Aten. Prim. 2019, 51, 406-415. [CrossRef]

156. Johnson, M.I.; Claydon, L.S.; Herbison, G.P.; Jones, G.; Paley, C.A. Transcutaneous electrical nerve stimulation (TENS) for fibromyalgia in adults. Cochrane Database Syst. Rev. 2017, 10, CD012172. [CrossRef] 
157. National Institute for Health and Care Excellence. Chronic Pain (Primary and Secondary) in over 16s: Assessment of All Chronic Pain and Management of Chronic Primary Pain (NG193); National Institute for Health and Care Excellence: London, UK, 2021; pp. 1-36.

158. Cheong, Y.C.; Smotra, G.; Williams, A. Non-surgical interventions for the management of chronic pelvic pain. Cochrane Database Syst. Rev. 2014, 3, CD008797. [CrossRef] [PubMed]

159. Cohen, J.M.; Fagin, A.P.; Hariton, E.; Niska, J.R.; Pierce, M.W.; Kuriyama, A.; Whelan, J.S.; Jackson, J.L.; Dimitrakoff, J.D. Therapeutic intervention for chronic prostatitis/chronic pelvic pain syndrome (CP/CPPS): A systematic review and metaanalysis. PLoS ONE 2012, 7, e41941. [CrossRef] [PubMed]

160. Igwea, S.E.; Tabansi-Ochuogu, C.S.; Abaraogu, U.O. TENS and heat therapy for pain relief and quality of life improvement in individuals with primary dysmenorrhea: A systematic review. Complement. Clin. Pr. 2016, 24, 86-91. [CrossRef] [PubMed]

161. Kannan, P.; Claydon, L.S. Some physiotherapy treatments may relieve menstrual pain in women with primary dysmenorrhea: A systematic review. J. Physiother. 2014, 60, 13-21. [CrossRef] [PubMed]

162. Honda, Y.; Sakamoto, J.; Hamaue, Y.; Kataoka, H.; Kondo, Y.; Sasabe, R.; Goto, K.; Fukushima, T.; Oga, S.; Sasaki, R.; et al. Effects of Physical-Agent Pain Relief Modalities for Fibromyalgia Patients: A Systematic Review and Meta-Analysis of Randomized Controlled Trials. Pain Res. Manag. 2018, 2018, 2930632. [CrossRef]

163. Ibanez-Vera, A.J.; Garcia-Romero, J.C.; Alvero-Cruz, J.R. Fisioterapia pasiva para el tratamiento del sindrome de fibromialgia. Una revision sistematica (Passive physical therapy for the treatment of fibromyalgia syndrome. A systematic review). Fisioterapia 2017, 39, 216-222. [CrossRef]

164. Ricci, N.A.; Dias, C.N.; Driusso, P. The use of electrothermal and phototherapeutic methods for the treatment of fibromyalgia syndrome: A systematic review. Rev. Bras. Fisioter. 2010, 14, 1-9. [CrossRef]

165. Page, M.J.; Green, S.; McBain, B.; Surace, S.J.; Deitch, J.; Lyttle, N.; Mrocki, M.A.; Buchbinder, R. Manual therapy and exercise for rotator cuff disease. Cochrane Database Syst. Rev. 2016, 6, CD012224. [CrossRef]

166. Wu, X.; Chung, V.C.; Hui, E.P.; Ziea, E.T.; Ng, B.F.; Ho, R.S.; Tsoi, K.K.; Wong, S.Y.; Wu, J.C. Effectiveness of acupuncture and related therapies for palliative care of cancer: Overview of systematic reviews. Sci. Rep. 2015, 5, 16776. [CrossRef]

167. Bao, Y.J.; Kong, X.Y.; Yang, L.P.; Liu, R.; Shi, Z.; Li, W.D.; Hua, B.J.; Hou, W. Complementary and Alternative Medicine for Cancer Pain: An Overview of Systematic Reviews. Evid. Based Complement. Altern. Med. 2014, 2014, 170396. [CrossRef]

168. Hurlow, A.; Bennett, M.I.; Robb, K.A.; Johnson, M.I.; Simpson, K.H.; Oxberry, S.G. Transcutaneous electric nerve stimulation (TENS) for cancer pain in adults. Cochrane Database Syst. Rev. 2012, 3, CD006276. [CrossRef]

169. Zeng, H.; Pacheco-Barrios, K.; Cao, Y.; Li, Y.; Zhang, J.; Yang, C.; Fregni, F. Non-invasive neuromodulation effects on painful diabetic peripheral neuropathy: A systematic review and meta-analysis. Sci. Rep. 2020, 10, 19184. [CrossRef]

170. Desmeules, F.; Boudreault, J.; Roy, J.S.; Dionne, C.E.; Fremont, P.; MacDermid, J.C. Efficacy of transcutaneous electrical nerve stimulation for rotator cuff tendinopathy: A systematic review. Physiotherapy 2016, 102, 41-49. [CrossRef] [PubMed]

171. Chen, C.-C.; Chuang, Y.-F.; Huang, A.C.-W.; Chen, C.-K.; Chang, Y.-J. The antalgic effects of non-invasive physical modalities on central post-stroke pain: A systematic review. J. Phys. Sci. 2016, 28, 1369-1373. [CrossRef] [PubMed]

172. Harvey, L.A.; Glinsky, J.V.; Bowden, J.L. The effectiveness of 22 commonly administered physiotherapy interventions for people with spinal cord injury: A systematic review. Spinal Cord 2016, 54, 914-923. [CrossRef] [PubMed]

173. Boldt, I.; Eriks-Hoogland, I.; Brinkhof, M.W.; de Bie, R.; Joggi, D.; von Elm, E. Non-pharmacological interventions for chronic pain in people with spinal cord injury. Cochrane Database Syst. Rev. 2014, 11, CD009177. [CrossRef] [PubMed]

174. Hawk, C.; Minkalis, A.L.; Khorsan, R.; Daniels, C.J.; Homack, D.; Gliedt, J.A.; Hartman, J.A.; Bhalerao, S. Systematic Review of Nondrug, Nonsurgical Treatment of Shoulder Conditions. J. Manip. Physiol. 2017, 40, 293-319. [CrossRef] [PubMed]

175. Haik, M.N.; Alburquerque-Sendin, F.; Moreira, R.F.; Pires, E.D.; Camargo, P.R. Effectiveness of physical therapy treatment of clearly defined subacromial pain: A systematic review of randomised controlled trials. Br. J. Sports Med. 2016, 50, 1124-1134. [CrossRef]

176. Page, M.J.; Green, S.; Mrocki, M.A.; Surace, S.J.; Deitch, J.; McBain, B.; Lyttle, N.; Buchbinder, R. Electrotherapy modalities for rotator cuff disease. Cochrane Database Syst. Rev. 2016, 6, CD012225. [CrossRef]

177. Page, M.J.; Green, S.; Kramer, S.; Johnston, R.V.; McBain, B.; Buchbinder, R. Electrotherapy modalities for adhesive capsulitis (frozen shoulder). Cochrane Database Syst. Rev. 2014, 10, CD011324. [CrossRef]

178. Johansson, K.; Oberg, B.; Adolfsson, L.; Foldevi, M. A combination of systematic review and clinicians' beliefs in interventions for subacromial pain. Br. J. Gen. Pr. 2002, 52, 145-152.

179. Hökkä, M.; Kaakinen, P.; Pölkki, T. A systematic review: Non-pharmacological interventions in treating pain in patients with advanced cancer. J. Adv. Nurs. 2012, 68, 1954-1969. [CrossRef]

180. Robb, K.A.; Bennett, M.I.; Johnson, M.I.; Simpson, K.J.; Oxberry, S.G. Transcutaneous electric nerve stimulation (TENS) for cancer pain in adults. Cochrane Database Syst. Rev. 2008, 3, CD006276.

181. Pan, C.X.; Morrison, R.S.; Ness, J.; Fugh-Berman, A.; Leipzig, R.M. Complementary and alternative medicine in the management of pain, dyspnea, and nausea and vomiting near the end of life. A systematic review. J. Pain Symptom Manag. 2000, 20, 374-387. [CrossRef]

182. Pieber, K.; Herceg, M.; Paternostro-Sluga, T. Electrotherapy for the treatment of painful diabetic peripheral neuropathy: A review. J. Rehabil. Med. 2010, 42, 289-295. [CrossRef] 
183. Dion, S.; Wong, J.J.; Cote, P.; Yu, H.; Sutton, D.; Randhawa, K.; Southerst, D.; Varatharajan, S.; Stern, P.J.; Nordin, M.; et al. Are passive physical modalities effective for the management of common soft tissue injuries of the elbow? A systematic review by the Ontario Protocol for Traffic Injury Management (OPTIMa) collaboration. Clin. J. Pain 2017, 33, 71-86. [CrossRef]

184. Wu, Y.-C.; Tsai, W.-C.; Tu, Y.-K.; Yu, T.-Y. Comparative Effectiveness of Nonoperative Treatments for Chronic Calcific Tendinitis of the Shoulder: A Systematic Review and Network Meta-Analysis of Randomized Controlled Trials. Arch. Phys. Med. Rehabil. 2017, 98, 1678-1692.e6. [CrossRef]

185. Dingemanse, R.; Randsdorp, M.; Koes, B.W.; Huisstede, B.M. Evidence for the effectiveness of electrophysical modalities for treatment of medial and lateral epicondylitis: A systematic review. Br. J. Sports Med. 2014, 48, 957-965. [CrossRef]

186. Ramos-Valero, L.; Meseguer-Henarejos, A.B. Physiotherapy treatments for patients with shoulder pain after stroke. A systematic review. Fisioterapia 2013, 35, 214-223. [CrossRef]

187. Mehta, S.; Orenczuk, K.; McIntyre, A.; Willems, G.; Wolfe, D.L.; Hsieh, J.T.C.; Short, C.; Loh, E.; Teasell, R.W. Neuropathic Pain Post Spinal Cord Injury Part 1: Systematic Review of Physical and Behavioral Treatment. Top. Spinal Cord Inj. Rehabil. 2013, 19, 61-77. [CrossRef]

188. Fattal, C.; Kong, A.S.D.; Gilbert, C.; Ventura, M.; Albert, T. What is the efficacy of physical therapeutics for treating neuropathic pain in spinal cord injury patients? Ann. Phys. Rehabil. Med. 2009, 52, 149-166. [CrossRef]

189. Kwan, I.; Wang, R.; Pearce, E.; Bhattacharya, S. Pain relief for women undergoing oocyte retrieval for assisted reproduction. Cochrane Database Syst. Rev. 2018, 5, CD004829. [CrossRef]

190. Mujezinovic, F.; Alfirevic, Z. Analgesia for amniocentesis or chorionic villus sampling. Cochrane Database Syst. Rev. 2011, 11, CD008580. [CrossRef] [PubMed]

191. Ngee-Ming, G.; Tamsin, D.; Rai, B.P.; Somani, B.K. Complementary approaches to decreasing discomfort during shockwave lithotripsy (SWL). Urolithiasis 2014, 42, 189-193. [CrossRef]

192. Amatya, B.; Young, J.; Khan, F. Non-pharmacological interventions for chronic pain in multiple sclerosis. Cochrane Database Syst. Rev. 2018, 12, CD012622. [CrossRef] [PubMed]

193. Jawahar, R.; Oh, U.; Yang, S.; Lapane, K.L. Alternative approach: A systematic review of non-pharmacological non-spastic and non-trigeminal pain management in multiple sclerosis. Eur. J. Phys. Rehabil. Med. 2014, 50, 567-577. [PubMed]

194. Al-Smadi, J.; Warke, K.; Wilson, I.; Cramp, A.; Noble, G.; Walsh, D.; Lowe-Strong, A. A pilot investigation of the hypoalgesic effects of transcutaneous electrical nerve stimulation upon low back pain in people with multiple sclerosis. Clin. Rehabil. 2003, 17, 742-749. [CrossRef]

195. Warke, K.; Al-Smadi, J.; Baxter, G.D.; Walsh, D.M.; Lowe-Strong, A.S. A double blind, placebo controlled, randomised, clinical trial investigating the efficacy of transcutaneous electrical nerve stimulation for low back pain in a multiple sclerosis population. Mult. Scler. 2004, 10, S107.

196. Kwan, I.; Bhattacharya, S.; Knox, F.; McNeil, A. Pain relief for women undergoing oocyte retrieval for assisted reproduction. Cochrane Database Syst. Rev. 2013, 1, CD004829. [CrossRef]

197. Fleming, P.S.; Strydom, H.; Katsaros, C.; MacDonald, L.C.I.; Curatolo, M.; Fudalej, P.; Pandis, N. Non-pharmacological interventions for alleviating pain during orthodontic treatment. Cochrane Database Syst. Rev. 2016, 12, CD010263. [CrossRef]

198. Pittler, M.H.; Ernst, E. Complementary therapies for neuropathic and neuralgic pain: Systematic review. Clin. J. Pain 2008, 24, 731-733. [CrossRef]

199. Amatya, B.; Khan, F.; La Mantia, L.; Demetrios, M.; Wade, D.T. Non pharmacological interventions for spasticity in multiple sclerosis. Cochrane Database Syst. Rev. 2013, 2, CD009974. [CrossRef]

200. Mills, P.B.; Dossa, F. Transcutaneous Electrical Nerve Stimulation for Management of Limb Spasticity: A Systematic Review. Am. J. Phys. Med. Rehabil. 2016, 95, 309-318. [CrossRef]

201. Fernandez-Tenorio, E.; Serrano-Munoz, D.; Avendano-Coy, J.; Gomez-Soriano, J. Transcutaneous electrical nerve stimulation for spasticity: A systematic review. Neurologia 2019, 34, 451-460. [CrossRef] [PubMed]

202. Synnot, A.; Chau, M.; Pitt, V.; O’Connor, D.; Gruen, R.L.; Wasiak, J.; Clavisi, O.; Pattuwage, L.; Phillips, K. Interventions for managing skeletal muscle spasticity following traumatic brain injury. Cochrane Database Syst. Rev. 2017, 11, CD008929. [CrossRef] [PubMed]

203. Johnson, M.I.; Mulvey, M.R.; Bagnall, A.M. Transcutaneous electrical nerve stimulation (TENS) for phantom pain and stump pain following amputation in adults. Cochrane Database Syst. Rev. 2015, 8, CD007264. [CrossRef] [PubMed]

204. Ottawa, P. Ottawa Panel Evidence-Based Clinical Practice Guidelines for Electrotherapy and Thermotherapy Interventions in the Management of Rheumatoid Arthritis in Adults. Phys. Ther. 2004, 84, 1016-1043.

205. Brosseau, L.; Judd, M.G.; Marchand, S.; Robinson, V.A.; Tugwell, P.; Wells, G.; Yonge, K. Transcutaneous electrical nerve stimulation (TENS) for the treatment of rheumatoid arthritis in the hand. Cochrane Database Syst. Rev. 2003, 2, CD004377. [CrossRef] [PubMed]

206. National Institute for Health and Care Excellence. Rheumatoid Arthritis in Adults. Available online: www.nice.org.uk/NG100 (accessed on 17 October 2019).

207. Tao, H.; Wang, T.; Dong, X.; Guo, Q.; Xu, H.; Wan, Q. Effectiveness of transcutaneous electrical nerve stimulation for the treatment of migraine: A meta-analysis of randomized controlled trials. J. Headache Pain 2018, 19, 42. [CrossRef]

208. Smart, K.M.; Wand, B.M.; O'Connell, N.E. Physiotherapy for pain and disability in adults with complex regional pain syndrome (CRPS) types I and II. Cochrane Database Syst. Rev. 2016, 2, CD010853. [CrossRef] 
209. Hu, X.; Trevelyan, E.; Yang, G.; Lee, M.S.; Lorenc, A.; Liu, J.; Robinson, N. The effectiveness of acupuncture/TENS for phantom limb syndrome. I: A systematic review of controlled clinical trials. Eur. J. Integr. Med. 2014, 6, 355-364. [CrossRef]

210. Halbert, J.; Crotty, M.; Cameron, I.D. Evidence for the optimal management of acute and chronic phantom pain: A systematic review. Clin. J. Pain 2002, 18, 84-92. [CrossRef]

211. Bronfort, G.; Nilsson, N.; Haas, M.; Evans, R.; Goldsmith, C.H.; Assendelft, W.J.; Bouter, L.M. Non-invasive physical treatments for chronic/recurrent headache. Cochrane Database Syst. Rev. 2004, 3, CD001878.

212. Huisstede, B.M.A.; Hoogvliet, P.; Franke, T.P.C.; Randsdorp, M.S.; Koes, B.W. Carpal tunnel syndrome: Effectiveness of physical therapy and electrophysical modalities. An updated systematic review of randomized controlled trials. Arch. Phys. Med. Rehabil. 2018, 99, 1623-1634.e23. [CrossRef] [PubMed]

213. Peters, S.; Page, M.J.; Coppieters, M.W.; Ross, M.; Johnston, V. Rehabilitation following carpal tunnel release. Cochrane Database Syst. Rev. 2016, 2, CD004158. [CrossRef] [PubMed]

214. Perillo, S.; Boyle, M.J. Pre-hospital femoral neck fracture management: A review of the literature. J. Paramed. Pr. 2013, 5, 99-103. [CrossRef]

215. Deussen, A.R.; Ashwood, P.; Martis, R.; Stewart, F.; Grzeskowiak, L.E. Relief of pain due to uterine cramping/involution after birth. Cochrane Database Syst. Rev. 2020, 10, CD004908. [CrossRef] [PubMed]

216. Deussen, A.R.; Ashwood, P.; Martis, R. Analgesia for relief of pain due to uterine cramping/involution after birth. Cochrane Database Syst. Rev. 2011, 5, CD004908. [CrossRef] [PubMed]

217. Pal, S.; Dixit, R.; Moe, S.; Godinho, M.A.; Abas, A.B.; Ballas, S.K.; Ram, S.; Yousuf, U.A.M. Transcutaneous electrical nerve stimulation (TENS) for pain management in sickle cell disease. Cochrane Database Syst. Rev. 2020, 3, CD012762. [CrossRef]

218. De Andres, J.; Sanchis-Lopez, N.; Asensio-Samper, J.M.; Fabregat-Cid, G.; Villanueva-Perez, V.L.; Monsalve Dolz, V.; Minguez, A. Vulvodynia-An Evidence-Based Literature Review and Proposed Treatment Algorithm. Pain Pr. 2016, 16, 204-236. [CrossRef]

219. Liao, C.D.; Tsauo, J.Y.; Liou, T.H.; Chen, H.C.; Rau, C.L. Efficacy of Noninvasive Stellate Ganglion Blockade Performed Using Physical Agent Modalities in Patients with Sympathetic Hyperactivity-Associated Disorders: A Systematic Review and MetaAnalysis. PLoS ONE 2016, 11, e0167476. [CrossRef]

220. Oor, J.E.; Unlu, C.; Hazebroek, E.J. A systematic review of the treatment for abdominal cutaneous nerve entrapment syndrome. Am. J. Surg. 2016, 212, 165-174. [CrossRef]

221. Mansilla, J.R.; Sánchez, B.G.; de Toro Garcíac, A.; López-Arza, M.V.G. Eficacia de la estimulación eléctrica transcutánea en la neuralgia del trigémino. Rehabilitacion 2016, 50, 81-86. [CrossRef]

222. Kovacs, F.M.; Urrutia, G.; Alarcon, J.D. Surgery versus conservative treatment for symptomatic lumbar spinal stenosis: A systematic review of randomized controlled trials. Spine 2011, 36, E1335-E1351. [CrossRef] [PubMed]

223. McNeely, M.L.; Armijo Olivo, S.; Magee, D.J. A systematic review of the effectiveness of physical therapy interventions for temporomandibular disorders. Phys. Ther. 2006, 86, 710-725. [CrossRef]

224. Dailey, D.L.; Vance, C.G.T.; Rakel, B.A.; Zimmerman, M.B.; Embree, J.; Merriwether, E.N.; Geasland, K.M.; Chimenti, R.; Williams, J.M.; Golchha, M.; et al. Transcutaneous Electrical Nerve Stimulation Reduces Movement-Evoked Pain and Fatigue: A Randomized, Controlled Trial. Arthritis Rheumatol. 2020, 72, 824-836. [CrossRef]

225. Atamaz, F.C.; Durmaz, B.; Baydar, M.; Demircioglu, O.Y.; Iyiyapici, A.; Kuran, B.; Oncel, S.; Sendur, O.F. Comparison of the efficacy of transcutaneous electrical nerve stimulation, interferential currents, and shortwave diathermy in knee osteoarthritis: A double-blind, randomized, controlled, multicenter study. Arch. Phys. Med. Rehabil. 2012, 93, 748-756. [CrossRef] [PubMed]

226. Palmer, S.; Domaille, M.; Cramp, F.; Walsh, N.; Pollock, J.; Kirwan, J.; Johnson, M.I. Transcutaneous electrical nerve stimulation as an adjunct to education and exercise for knee osteoarthritis: A randomised controlled trial. Arthritis Care Res. 2013, 66, 387-394. [CrossRef] [PubMed]

227. Rakel, B.; Frantz, R. Effectiveness of transcutaneous electrical nerve stimulation on postoperative pain with movement. J. Pain 2003, 4, 455-464. [CrossRef]

228. Baez-Suarez, A.; Martin-Castillo, E.; Garcia-Andujar, J.; Garcia-Hernandez, J.A.; Quintana-Montesdeoca, M.P.; Loro-Ferrer, J.F. Evaluation of different doses of transcutaneous nerve stimulation for pain relief during labour: A randomized controlled trial. Trials 2018, 19, 652. [CrossRef]

229. Tsen, L.C.; Thomas, J.; Segal, S.; Datta, S.; Bader, A.M. Transcutaneous electrical nerve stimulation does not augment epidural labor analgesia. J. Clin. Anesth. 2001, 13, 571-575. [CrossRef]

230. Thomas, I.L.; Tyle, V.; Webster, J.; Neilson, A. An evaluation of transcutaneous electrical nerve stimulation for pain relief in labour. Aust. N. Z. J. Obs. Gynaecol. 1988, 28, 182-189. [CrossRef] [PubMed]

231. Bai, H.Y.; Bai, H.Y.; Yang, Z.Q. Effect of transcutaneous electrical nerve stimulation therapy for the treatment of primary dysmenorrheal. Medicine 2017, 96, e7959. [CrossRef] [PubMed]

232. Başkurt, Z.; Başkurt, F.; Özcan, A.; Yilmaz, Ö. The immediate effects of heat and TENS on pressure pain threshold and pain intensity in patients with Stage I shoulder impingement syndrome. Pain Clin. 2006, 18, 81-85. [CrossRef]

233. Bulut, M.; Özcan, A.; Çakan, T.; Mektas, M.; Çulha, C. The Comparison of Effectiveness of TENS and Placebo TENS in Peripheral Neuropathic Pain in Patients with Type II Diabetes Mellitus. Turk. Klin. J. Med. Sci. 2011, 31, 913-918. [CrossRef]

234. Amer-Cuenca, J.J.; Goicoechea, C.; Girona-López, A.; Andreu-Plaza, J.L.; Palao-Román, R.; Martínez-Santa, G.; Lisón, J.F. Pain relief by applying transcutaneous electrical nerve stimulation (TENS) during unsedated colonoscopy: A randomized double-blind placebo-controlled trial. Eur. J. Pain 2011, 15, 29-35. [CrossRef] [PubMed] 
235. Johnson, M.I. Resolving Long-Standing Uncertainty about the Clinical Efficacy of Transcutaneous Electrical Nerve Stimulation (TENS) to Relieve Pain: A Comprehensive Review of Factors Influencing Outcome. Medicina 2021, 57, 378. [CrossRef]

236. Nnoaham, K.E.; Kumbang, J. WITHDRAWN: Transcutaneous electrical nerve stimulation (TENS) for chronic pain. Cochrane Database Syst. Rev. 2014, 7, CD003222. [CrossRef]

237. Treede, R.D.; Rief, W.; Barke, A.; Aziz, Q.; Bennett, M.I.; Benoliel, R.; Cohen, M.; Evers, S.; Finnerup, N.B.; First, M.B.; et al. A classification of chronic pain for ICD-11. Pain 2015, 156, 1003-1007. [CrossRef]

238. Smith, B.H.; Fors, E.A.; Korwisi, B.; Barke, A.; Cameron, P.; Colvin, L.; Richardson, C.; Rief, W.; Treede, R.D.; The IASP Taskforce for the Classification of Chronic Pain. The IASP classification of chronic pain for ICD-11: Applicability in primary care. Pain 2019, 160, 83-87. [CrossRef]

239. Ioannidis, J.P. The Mass Production of Redundant, Misleading, and Conflicted Systematic Reviews and Meta-analyses. Milbank Q. 2016, 94, 485-514. [CrossRef]

240. Bennett, M.I.; Hughes, N.; Johnson, M.I. Methodological quality in randomised controlled trials of transcutaneous electric nerve stimulation for pain: Low fidelity may explain negative findings. Pain 2011, 152, 1226-1232. [CrossRef]

241. Gladwell, P.W.; Badlan, K.; Cramp, F.; Palmer, S. Direct and Indirect Benefits Reported by Users of Transcutaneous Electrical Nerve Stimulation for Chronic Musculoskeletal Pain: Qualitative Exploration Using Patient Interviews. Phys. Ther. 2015, 95, 1518-1528. [CrossRef]

242. Gladwell, P.W.; Cramp, F.; Palmer, S. Matching the perceived benefits of Transcutaneous Electrical Nerve Stimulation (TENS) for chronic musculoskeletal pain against Patient Reported Outcome Measures using the International Classification of Functioning, Disability and Health (ICF). Physiotherapy 2020, 106, 128-135. [CrossRef]

243. Gladwell, P.W.; Badlan, K.; Cramp, F.; Palmer, S. Problems, Solutions, and Strategies Reported by Users of Transcutaneous Electrical Nerve Stimulation for Chronic Musculoskeletal Pain: Qualitative Exploration Using Patient Interviews. Phys. Ther. 2016, 96, 1039-1048. [CrossRef] [PubMed]

244. National Institute for Health and Care Excellence. Low Back Pain and Sciatica in over 16s: Assessment and Management; Clinical guideline [NG59]; National Institute for Health and Care Excellence: London, UK, 2016; pp. 1-18.

245. Almeida, T.; Figueiredo, F.; Barbosa Filho, V.C.; de Abreu, L.C.; Fonseca, F.L.A.; Adami, F. Effects of transcutaneous electrical nerve stimulation (TENS) on proinflammatory cytokines: Protocol for systematic review. Syst. Rev. 2017, 6, 139. [CrossRef] [PubMed]

246. Anim-Somuah, M.; Smyth, R.M.D.; Cyna, A.M.; Cuthbert, A. Epidural versus non-epidural or no analgesia for pain management in labour. Cochrane Database Syst. Rev. 2018. [CrossRef]

247. Arendt, K.W.; Tessmer-Tuck, J.A. Nonpharmacologic labor analgesia. Clin. Perinatol. 2013, 40, 351-371. [CrossRef] [PubMed]

248. Barkatsa, V.; Iliadis, C.; Moraitis, V.; Syrmos, N.; Tzagarakis, M.; Tsipras, K. Physiotherapy interventions for the management of whiplash injuries. Bone 2011, 48, S271. [CrossRef]

249. Binder, A.; Baron, R. Utility of transcutaneous electrical nerve stimulation in neurologic pain disorders. Neurology 2010, 74, 104-105. [CrossRef] [PubMed]

250. Bjordal, J.M.; Baxter, D.; Leal, E., Jr.; Cheing, G.; Laakso, L. Evidence based use of electrophysical agents for managing musculoskeletal pain. Physiotherapy 2015, 101, eS8-eS9. [CrossRef]

251. Briones-Areán, Y.; Soto-González, M. Effectiveness of physiotherapy in shoulder impingement syndrome. Fisioterapia 2014, 36, 187-196. [CrossRef]

252. Brosseau, L.; Yonge, K.; Marchand, S.; Robinson, V.; Wells, G.; Tugwell, P. Efficacy of transcutaneous electrical nerve stimulation (TENS) for rheumatoid arthritis: A systematic review. Phys. Ther. Rev. 2002, 7, 199-208. [CrossRef]

253. Cadalso, R.T.; Daugherty, J.; Holmes, C.; Ram, S.; Enciso, R. Efficacy of Electrical Stimulation of the Occipital Nerve in Intractable Primary Headache Disorders: A Systematic Review with Meta-Analyses. J. Oral Facial Pain Headache 2018, 32, 40-52. [CrossRef] [PubMed]

254. Cameron, M.; Lonergan, E.; Lee, H. Transcutaneous electrical nerve stimulation (TENS) for dementia. Cochrane Database Syst. Rev. 2003, CD004032. [CrossRef]

255. Campo-Prieto, P.; Rodriguez-Fuentes, G. Effectiveness of mirror therapy in phantom limb pain: A literature review. Neurologia 2018. [CrossRef]

256. Chan, P.S.L. Postherpetic neuralgia: Review of treatment modalities. Pain Res. Manag. 2000, 5, 69-74. [CrossRef]

257. Chaparro, L.E.; Furlan, A.D.; Deshpande, A.; Mailis-Gagnon, A.; Atlas, S.; Turk, D.C. Opioids compared to placebo or other treatments for chronic low-back pain. Cochrane Database Syst. Rev. 2013, 8, CD004959. [CrossRef]

258. Chen, C.; Tabasam, G.; Johnson, M. Does the pulse frequency of Transcutaneous Electrical Nerve Stimulation (TENS) influence hypoalgesia? A systematic review of studies using experimental pain and healthy human participants. Physiotherapy 2008, 94, 11-20. [CrossRef]

259. Chesterton, L.S.; van der Windt, D.A.; Sim, J.; Lewis, M.; Mallen, C.D.; Mason, E.E.; Warlow, C.; Vohora, K.; Hay, E.M. Transcutaneous electrical nerve stimulation for the management of tennis elbow: A pragmatic randomized controlled trial: The TATE trial (ISRCTN 87141084). BMC Musculoskelet. Disord. 2009, 10, 156. [CrossRef]

260. Choi, G.-H.; Wieland, L.S.; Lee, H.; Sim, H.; Lee, M.S.; Shin, B.-C. Acupuncture and related interventions for the treatment of symptoms associated with carpal tunnel syndrome. Cochrane Database Syst. Rev. 2018, 12, CD011215. [CrossRef] 
261. Claydon, L.S.; Chesterton, L.S.; Barlas, P.; Sim, J. Dose-specific effects of transcutaneous electrical nerve stimulation (TENS) on experimental pain: A systematic review. Clin. J. Pain 2011, 27, 635-647. [CrossRef]

262. Claydon, L.S.; Chesterton, L.S.; Sim, J.; Barlas, P. The hypoalgesic efficacy of TENS parameters on experimental pain models in healthy humans: A systematic review. N. Z. J. Physiother. 2008, 36, 84-85.

263. Dingemanse, R.; Randsdorp, M.; Koes, B.W.; Huisstede, B.M. Evidence for the effectiveness of electrophysical modalities for treatment of medial and lateral epicondylitis: A systematic review. Br. J. Sports Med. 2013, 48, 957-965. [CrossRef] [PubMed]

264. Doyle, S.; Bennett, S.; Fasoli, S.E.; McKenna, K.T. Interventions for sensory impairment in the upper limb after stroke. Cochrane Database Syst. Rev. 2010. [CrossRef]

265. Ducic, I.; Felder, J.M., 3rd; Fantus, S.A. A systematic review of peripheral nerve interventional treatments for chronic headaches. Ann. Plast. Surg. 2014, 72, 439-445. [CrossRef]

266. Eberhart, L.H.; Morin, A.M.; Kranke, P.; Geldner, G.; Wulf, H. Transient neurologic symptoms after spinal anesthesia. A quantitative systematic review (meta-analysis) of randomized controlled studies. Anaesthesist 2002, 51, 539-546. [CrossRef] [PubMed]

267. Eccleston, C.; Fisher, E.; Thomas, K.H.; Hearn, L.; Derry, S.; Stannard, C.; Knaggs, R.; Moore, R.A. Interventions for the reduction of prescribed opioid use in chronic non-cancer pain. Cochrane Database Syst. Rev. 2017, 11, Cd010323. [CrossRef] [PubMed]

268. Ely, S. Transcutaneous electrical nerve stimulation (TENS) at acupuncture points for the management of chronic pain: A narrative review. In Proceedings of the 4th European Congress of the European Region of the World Confederation of Physical Therapy (ER-WCPT) Abstracts, Liverpool, UK, 11-12 November 2016. [CrossRef]

269. Fargas-Babjak, A. Acupuncture, transcutaneous electrical nerve stimulation, and laser therapy in chronic pain. Clin. J. Pain 2001, 17, S105-S113. [CrossRef]

270. Foletti, A.; Durrer, A.; Buchser, E. Neurostimulation technology for the treatment of chronic pain: A focus on spinal cord stimulation. Expert Rev. Med. Devices 2007, 4, 201-214. [CrossRef]

271. Freynet, A.; Falcoz, P. Kinésithérapie basée sur les preuves en chirurgie thoracique après résection pulmonaire par thoracotomie: Evidence-based physiotherapy after lung resection via thoracotomy. Kinésithér. Rev. 2011, 11, 34-44. [CrossRef]

272. Fu, X.; Wang, Y.; Wang, C.; Wu, H.; Li, J.; Li, M.; Ma, Q.; Yang, W. A mixed treatment comparison on efficacy and safety of treatments for spasticity caused by multiple sclerosis: A systematic review and network meta-analysis. Clin. Rehabil. 2018, 32, 713-721. [CrossRef] [PubMed]

273. Gabler, C.M.; Lepley, A.S.; Uhl, T.L.; Mattacola, C.G. Comparison of Transcutaneous Electrical Nerve Stimulation and Cryotherapy for Increasing Quadriceps Activation in Patients With Knee Pathologies. J. Sport Rehabil. 2016, 25, 294-300. [CrossRef]

274. Gadsby, J.G.; Flowerdew, M.W. Transcutaneous electrical nerve stimulation and acupuncture-like transcutaneous electrical nerve stimulation for chronic low back pain. Cochrane Database Syst. Rev. 2000, CD000210.

275. Gadsby, J.G.; Flowerdew, M.W. WITHDRAWN: Transcutaneous electrical nerve stimulation and acupuncture-like transcutaneous electrical nerve stimulation for chronic low back pain. Cochrane Database Syst. Rev. 2007, CD000210. [CrossRef]

276. Gross, A.; Langevin, P.; Burnie, S.J.; Bedard-Brochu, M.S.; Empey, B.; Dugas, E.; Faber-Dobrescu, M.; Andres, C.; Graham, N.; Goldsmith, C.H.; et al. Manipulation and mobilisation for neck pain contrasted against an inactive control or another active treatment (Cochrane review) [with consumer summary]. Cochrane Database Syst. Rev. 2005.

277. Hall, H.; McIntosh, G. Low back pain (acute). BMJ Clin. Evid. 2008, 2008, 1102.

278. Handy, J.; Salinas, S.; Blanchard, S.A.; Aitken, M.J. Meta-analysis examining the effectiveness of electrical stimulation in improving functional use of the upper limb in stroke patients. Phys. Occup. Ther. Geriatr. 2003, 21, 67-78. [CrossRef]

279. Hawker, G.A.; Mian, S.; Bednis, K.; Stanaitis, I. Osteoarthritis year 2010 in review: Non-pharmacologic therapy. Osteoarthr. Cartil. 2011, 19, 366-374. [CrossRef]

280. Ho, K.W.D.; Przkora, R.; Kumar, S. Sphenopalatine ganglion: Block, radiofrequency ablation and neurostimulation-A systematic review. J. Headache Pain 2017, 18, 118. [CrossRef]

281. Hoffman, R.M. Review: Transcutaneous electrical nerve stimulation is not effective for chronic low-back pain. $A C P J$. Club 2001, $135,9999$.

282. Hu, X.; Trevelyan, E.; Yang, G.; Lee, M.S.; Lorenc, A.; Liu, J.; Robinson, N. The effectiveness of acupuncture or TENS for phantom limb syndrome. II: A narrative review of case studies. Eur. J. Integr. Med. 2014, 6, 365-381. [CrossRef]

283. Hunsinger, M.; Smith, S.M.; Rothstein, D.; McKeown, A.; Parkhurst, M.; Hertz, S.; Katz, N.P.; Lin, A.H.; McDermott, M.P.; Rappaport, B.A.; et al. Adverse event reporting in nonpharmacologic, noninterventional pain clinical trials: ACTTION systematic review. Pain 2014, 155, 2253-2262. [CrossRef]

284. Jamtvedt, G.; Dahm, K.T.; Holm, I.; Odegaard-Jensen, J.; Flottorp, S. Choice of treatment modalities was not influenced by pain, severity or co-morbidity in patients with knee osteoarthritis. Physiother. Res. Int. 2010, 15, 16-23. [CrossRef] [PubMed]

285. Jayasekara, R. Transcutaneous electrical nerve stimulation for acute pain. J. Pain Manag. 2011, 4, 437-438.

286. Johnson, M.I. Transcutaneous electrical nerve stimulation: Review of effectiveness. Nurs. Stand. 2014, 28, 44-53. [CrossRef] [PubMed]

287. Johnson, M.I. The clinical effectiveness of TENS in pain management. Crit. Rev. Phys. Ther. Rehabil. 2000, 12, 131-149. [CrossRef]

288. Johnson, M.I. Transcutaneous Electrical Nerve Stimulation (TENS) and TENS-like devices. Do they provide pain relief? Pain Rev. 2001, 8, 121-128. [CrossRef] 
289. Johnson, M.I. Transcutaneous electrical nerve stimulation (TENS) as an adjunct for pain management in perioperative settings: A critical review. Expert Rev. Neurother. 2017, 17, 1013-1027. [CrossRef]

290. Johnson, M.I.; Bjordal, J.M. Transcutaneous electrical nerve stimulation for the management of painful conditions: Focus on neuropathic pain. Expert Rev. Neurother. 2011, 11, 735-753. [CrossRef] [PubMed]

291. Jordan, J.L.; Holden, M.A.; Mason, E.E.J.; Foster, N.E. Interventions to improve adherence to exercise for chronic musculoskeletal pain in adults. Cochrane Database Syst. Rev. 2010. [CrossRef]

292. Kang, J.; Li, N.; Wu, B. Therapeutic methods for knee osteoarthritis: Randomized controlled trial and systemic evaluation. Chin. J. Clin. Rehabil. 2005, 9, 27-30.

293. Khadilkar, A.; Milne, S.; Brosseau, L.; Wells, G.; Tugwell, P.; Robinson, V.; Shea, B.; Saginur, M. Transcutaneous electrical nerve stimulation for the treatment of chronic low back pain: A systematic review. Spine 2005, 30, 2657-2666. [CrossRef] [PubMed]

294. Khalil, N.; Nicotra, A.; Rakowicz, W. Treatment for meralgia paraesthetica. Cochrane Database Syst. Rev. 2012. [CrossRef]

295. Khan, F.; Amatya, B.; Bensmail, D.; Yelnik, A. Non-pharmacological interventions for spasticity in adults: An overview of systematic reviews. Ann. Phys. Rehabil. Med. 2019, 62, 265-273. [CrossRef] [PubMed]

296. Kirpalani, D.; Mitra, R. Cervical facet joint dysfunction: A review. Arch. Phys. Med. Rehabil. 2008, 89, 770-774. [CrossRef]

297. Klomp, T. Inhaled analgesia for pain management in labour. J. Evid. Based Med. 2012, 5, 241. [CrossRef]

298. Koes, B.W.; Assendelft, W.J.; van der Heijden, G.J.; Bouter, L.M.; Knipschild, P.G. Spinal manipulation and mobilisation for back and neck pain: A blinded review. BMJ 1991, 303, 1298-1303. [CrossRef]

299. Koes, B.W.; Assendelft, W.J.; van der Heijden, G.J.; Bouter, L.M. Spinal manipulation for low back pain. An updated systematic review of randomized clinical trials. Spine 1996, 21, 2860-2871; discussion 2872-2873. [CrossRef]

300. Koopman, F.S.; Beelen, A.; Gilhus, N.E.; de Visser, M.; Nollet, F. Treatment for postpolio syndrome. Cochrane Database Syst. Rev. 2015. [CrossRef]

301. Kosseim, M.; Rein, R.; McShane, C. Implementing evidence-based physiotherapy practice for treating children with low back pain: Are we there yet? Pediatr. Phys. Ther. 2008, 20, 179-184. [CrossRef]

302. Kroeling, P.; Gross, A.; Goldsmith, C.H.; Houghton, P.E. Electrotherapy for neck disorders. Cochrane Database Syst. Rev. 2005. [CrossRef]

303. Kus, G.; Yeldan, I. Strengthening the quadriceps femoris muscle versus other knee training programs for the treatment of knee osteoarthritis. Rheumatol. Int. 2019, 39, 203-218. [CrossRef] [PubMed]

304. Lee, S.; Abd-Elsayed, A. Some Non-FDA Approved Uses for Neuromodulation: A Review of the Evidence. Pain Pract. 2016, 16, 935-947. [CrossRef] [PubMed]

305. Lenza, M.; Buchbinder, R.; Johnston, R.V.; Ferrari, B.A.S.; Faloppa, F. Surgical versus conservative interventions for treating fractures of the middle third of the clavicle. Cochrane Database Syst. Rev. 2019. [CrossRef] [PubMed]

306. Lin, C.W.C.; Donkers, N.A.J.; Refshauge, K.M.; Beckenkamp, P.R.; Khera, K.; Moseley, A.M. Rehabilitation for ankle fractures in adults. Cochrane Database Syst. Rev. 2012. [CrossRef]

307. Lindsley, K.; Nichols, J.J.; Dickersin, K. Non-surgical interventions for acute internal hordeolum. Cochrane Database Syst. Rev. 2017. [CrossRef] [PubMed]

308. Mahmood, A.; Veluswamy, S.K.; Hombali, A.; Mullick, A.; Manikandan, N.; Solomon, J.M. Effect of Transcutaneous Electrical Nerve Stimulation on Spasticity in Adults With Stroke: A Systematic Review and Meta-analysis. Arch. Phys. Med. Rehabil. 2019, 100, 751-768. [CrossRef]

309. Marcolino, M.A.Z.; Hauck, M.; Stein, C.; Schardong, J.; Pagnussat, A.S.; Plentz, R.D.M. Effects of transcutaneous electrical nerve stimulation alone or as additional therapy on chronic post-stroke spasticity: Systematic review and meta-analysis of randomized controlled trials. Disabil. Rehabil. 2020, 42, 623-635. [CrossRef] [PubMed]

310. Martí-Carvajal, A.J.; Peña-Martí, G.E.; Comunián-Carrasco, G.; Martí-Peña, A.J. Interventions for treating painful sickle cell crisis during pregnancy. Cochrane Database Syst. Rev. 2009. [CrossRef] [PubMed]

311. Miller, J.; Gross, A. Manual therapy and exercise for neck pain: Clinical treatment pocket notes. Physiotherapy 2011, 97, eS1554-eS1555. [CrossRef]

312. Moisset, X.; Pereira, B.; Ciampi de Andrade, D.; Fontaine, D.; Lanteri-Minet, M.; Mawet, J. Neuromodulation techniques for acute and preventive migraine treatment: A systematic review and meta-analysis of randomized controlled trials. J. Headache Pain 2020, 21, 142. [CrossRef]

313. Mollon, B.; da Silva, V.; Busse, J.W.; Einhorn, T.A.; Bhandari, M. Electrical stimulation for long-bone fracture-healing: A meta-analysis of randomized controlled trials. J. Bone Jt. Surg. Am. 2008, 90, 2322-2330. [CrossRef]

314. Monaghan, B.; Caulfield, B.; O'Mathuna, D.P. Surface neuromuscular electrical stimulation for quadriceps strengthening pre and post total knee replacement. Cochrane Database Syst. Rev. 2010, CD007177. [CrossRef] [PubMed]

315. Muller, A. Apropos the meta-analyses, randomization and postoperative pain relief with transcutaneous nerve stimulation. Ann. Fr. D Anesth. Reanim. 1997, 16, 459-460. [CrossRef]

316. Mulvey, M.R.; Bagnall, A.; Johnson, M.I.; Marchant, P.R. Transcutaneous electrical nerve stimulation (TENS) for phantom pain and stump pain following amputation in adults. Cochrane Database Syst. Rev. 2010.

317. Mulvey, M.R.; Radford, H.E.; Fawkner, H.J.; Hirst, L.; Neumann, V.; Johnson, M.I. Transcutaneous electrical nerve stimulation for phantom pain and stump pain in adult amputees. Pain Pract. 2013, 13, 289-296. [CrossRef] 
318. Mulvey, M.R.; Bagnall, A.-M.; Marchant, P.R.; Johnson, M.I. Transcutaneous electrical nerve stimulation (TENS) for phantom pain and stump pain following amputation in adults: An extended analysis of excluded studies from a Cochrane systematic review. Phys. Ther. Rev. 2014, 19, 234-244. [CrossRef]

319. Munirama, S.; McLeod, G. A systematic review and meta-analysis of ultrasound versus electrical stimulation for peripheral nerve location and blockade. Anaesthesia 2015, 70, 1084-1091. [CrossRef]

320. Novak, S.; Nemeth, W.C. How clinically relevant is a meta-analysis of electrical nerve stimulation when based on heterogeneous disease states? Pain 2007, 131, 228-229; author reply 229-230. [CrossRef]

321. O'Connell, N.E.; Wand, B.M.; Marston, L.; Spencer, S.; Desouza, L.H. Non-invasive brain stimulation techniques for chronic pain. Cochrane Database Syst. Rev. 2014, CD008208. [CrossRef]

322. O'Connell, N.E.; Marston, L.; Spencer, S.; DeSouza, L.H.; Wand, B.M. Non-invasive brain stimulation techniques for chronic pain. Cochrane Database Syst. Rev. 2018. [CrossRef] [PubMed]

323. O'Gallagher, M.; Banteka, M.; Bunce, C.; Larkin, F.; Tuft, S.; Dahlmann-Noor, A. Systemic treatment for blepharokeratoconjunctivitis in children. Cochrane Database Syst. Rev. 2016. [CrossRef] [PubMed]

324. Pelland, L.; Brosseau, L.; Casimiro, L.; Welch, V.; Tugwell, P.; Wells, G.A. Electrical stimulation for the treatment of rheumatoid arthritis. Cochrane Database Syst. Rev. 2002. [CrossRef]

325. Poropat, G.; Giljaca, V.; Hauser, G.; Štimac, D. Enteral nutrition formulations for acute pancreatitis. Cochrane Database Syst. Rev. 2015. [CrossRef]

326. Price, C.I.; Pandyan, A.D. Electrical stimulation for preventing and treating post-stroke shoulder pain: A systematic Cochrane review. Clin. Rehabil. 2001, 15, 5-19. [CrossRef]

327. Proietti Cecchini, A.; Grazzi, L. Emerging therapies for chronic migraine. Curr. Pain Headache Rep. 2014, 18, 408. [CrossRef]

328. Redgrave, J.; Day, D.; Leung, H.; Laud, P.J.; Ali, A.; Lindert, R.; Majid, A. Safety and tolerability of Transcutaneous Vagus Nerve stimulation in humans; a systematic review. Brain Stimul. 2018, 11, 1225-1238. [CrossRef]

329. Reed, J.C. Review of acute and chronic pain published studies. J. Altern. Complement. Med. 1996, 2, 129-144; discussion 145-147. [CrossRef] [PubMed]

330. Renner, R.M.; Jensen, J.T.; Nichols, M.D.; Edelman, A. Pain control in first trimester surgical abortion. Cochrane Database Syst. Rev. 2009. [CrossRef]

331. Richards, B.L.; Whittle, S.L.; Buchbinder, R. Neuromodulators for pain management in rheumatoid arthritis. Cochrane Database Syst. Rev. 2012. [CrossRef]

332. Robb, K.; Oxberry, S.G.; Bennett, M.I.; Johnson, M.I.; Simpson, K.H.; Searle, R.D. A Cochrane Systematic Review of Transcutaneous Electrical Nerve Stimulation for Cancer Pain. J. Pain Symptom. Manag. 2009, 37, 746-753. [CrossRef] [PubMed]

333. Rojahn, R. Transcutaneous Electrostimulation for Osteoarthritis of the Knee. J. Pain Manag. 2011, 4, 447-449.

334. Rome, K.; Handoll, H.H.G.; Ashford, R.L. Interventions for preventing and treating stress fractures and stress reactions of bone of the lower limbs in young adults. Cochrane Database Syst. Rev. 2005. [CrossRef] [PubMed]

335. Rosted, P.; Andersen, C. Use of stimulation techniques in pain treatment. Ugeskr. Laeger. 2006, 168, 1982-1986.

336. Saarto, T.; Wiffen, P.J. Antidepressants for neuropathic pain. Cochrane Database Syst. Rev. 2007. [CrossRef] [PubMed]

337. Saulle, R.; Vecchi, S.; Gowing, L. Supervised dosing with a long-acting opioid medication in the management of opioid dependence. Cochrane Database Syst. Rev. 2017. [CrossRef] [PubMed]

338. Scott, N.A.; Moga, C.; Harstall, C. Managing low back pain in the primary care setting: The know-do gap. Pain Res. Manag. 2010, 15, 392-400. [CrossRef]

339. Singh, P.; Chaturvedi, A. Complementary and Alternative Medicine in Cancer Pain Management: A Systematic Review. Indian J. Palliat. Care 2015, 21, 105-115. [CrossRef]

340. Sluka, K.A.; Bjordal, J.M.; Marchand, S.; Rakel, B.A. What Makes Transcutaneous Electrical Nerve Stimulation Work? Making Sense of the Mixed Results in the Clinical Literature. Phys. Ther. 2013, 93, 1397-1402. [CrossRef] [PubMed]

341. Smith, C.A.; Levett, K.M.; Collins, C.T.; Dahlen, H.G.; Ee, C.C.; Suganuma, M. Massage, reflexology and other manual methods for pain management in labour. Cochrane Database Syst. Rev. 2018. [CrossRef] [PubMed]

342. Stuiver, M.M.; ten Tusscher, M.R.; Agasi-Idenburg, C.S.; Lucas, C.; Aaronson, N.K.; Bossuyt, P.M.M. Conservative interventions for preventing clinically detectable upper-limb lymphoedema in patients who are at risk of developing lymphoedema after breast cancer therapy. Cochrane Database Syst. Rev. 2015. [CrossRef]

343. Tashani, O.; Johnson, M. Transcutaneous Electrical Nerve Stimulation (TENS) A Possible Aid for Pain Relief in Developing Countries? Libyan J. Med. 2009, 4, 62-65. [CrossRef]

344. Tirlapur, S.A.; Vlismas, A.; Ball, E.; Khan, K.S. Nerve stimulation for chronic pelvic pain and bladder pain syndrome: A systematic review. Acta Obstet. Gynecol. Scand. 2013, 92, 881-887. [CrossRef]

345. Twycross, A.; Forgeron, P.; Williams, A. Paediatric nurses' postoperative pain management practices in hospital based non-critical care settings: A narrative review. Int. J. Nurs. Stud. 2015, 52, 836-863. [CrossRef] [PubMed]

346. Tzortziou Brown, V.; Underwood, M.; Mohamed, N.; Westwood, O.; Morrissey, D. Professional interventions for general practitioners on the management of musculoskeletal conditions. Cochrane Database Syst. Rev. 2016. [CrossRef]

347. Veves, A.; Backonja, M.; Malik, R.A. Painful diabetic neuropathy: Epidemiology, natural history, early diagnosis, and treatment options. Pain Med. 2008, 9, 660-674. [CrossRef] [PubMed]

348. Walsh, D.M. The evolution of TENS. Hong Kong Physiother. J. 2003, 21, 1-4. [CrossRef] 
349. Walsh, D.M.; Howe, T.E.; Johnson, M.I.; Sluka, K.A. Transcutaneous electrical nerve stimulation for acute pain. Cochrane Database Syst. Rev. 2009, CD006142.

350. Walsh, D.M.; Howe, T.E.; Johnson, M.I.; Moran, F.; Sluka, K.A. Transcutaneous electrical nerve stimulation for acute pain. Cochrane Database Syst. Rev. 2015. [CrossRef]

351. Weiner, D.K.; Ernst, E. Complementary and alternative approaches to the treatment of persistent musculoskeletal pain. Clin. J. Pain 2004, 20, 244-255. [CrossRef] [PubMed]

352. Wiffen, P.J. Pain and palliative care in the Issue Number 3, 2001 of The Cochrane Library. J. Pain Palliat. Care Pharmacother. 2002, 16, 81-86. [CrossRef] [PubMed]

353. Wiffen, P.J. Evidence-based pain management and palliative care in issue three for 2004 of The Cochrane Library. J. Pain Palliat. Care Pharmacother. 2005, 19, 63-65. [CrossRef] [PubMed]

354. Wiffen, P.J. Evidence-based pain management and palliative care systematic reviews in issue three for 2008 of The Cochrane Library. J. Pain Palliat. Care Pharmacother. 2009, 23, 69-71. [CrossRef] [PubMed]

355. Wiffen, P.J. Evidence-based pain management and palliative care in Issue Two for 2009 of The Cochrane Library. J. Pain Palliat. Care Pharmacother. 2009, 23, 290-294. [CrossRef] [PubMed]

356. Wiffen, P.J.; Derry, S.; Moore, R.A.; Kalso, E.A. Carbamazepine for chronic neuropathic pain and fibromyalgia in adults. Cochrane Database Syst. Rev. 2014. [CrossRef]

357. Zhang, W.; Moskowitz, R.W.; Nuki, G.; Abramson, S.; Altman, R.D.; Arden, N.; Bierma-Zeinstra, S.; Brandt, K.D.; Croft, P.; Doherty, M.; et al. OARSI recommendations for the management of hip and knee osteoarthritis, Part II: OARSI evidence-based, expert consensus guidelines. Osteoarthr. Cartil. 2008, 16, 137-162. [CrossRef]

358. Zakrzewska, J.M.; Akram, H. Neurosurgical interventions for the treatment of classical trigeminal neuralgia. Cochrane Database Syst. Rev. 2011. [CrossRef] 